Energy Systems Environmental Restoration Program ORNL Environmental Restoration Program

\title{
Additional Borehole Geophysical Logging at Waste Area Grouping 1 at Oak Ridge National Laboratory, Oak Ridge, Tennessee
}

Date Issued-July 1994

Prepared by

Bechtel National, Inc/CH2M Hill/Ogden/Peer

Oak Ridge, Tennessee

under subcontract 12B-93053C

Prepared for

U.S. Department of Energy

Office of Environmental Restoration and Waste Management

under budget and reporting code EW 20

Environmental Restoration and Waste Management Programs

Oak Ridge National Laboratory

Oak Ridge, Tenneasee 37831-6285

managed by

MARTIN MARIETTA ENERGY SYSTEMS, INC.

for the

U.S. DEPARTMENT OF ENERGY

under contract DE-ACO5-84OK21400 


\section{CONTENTS}

FIGURES $\ldots \ldots \ldots \ldots \ldots \ldots \ldots \ldots \ldots \ldots \ldots \ldots \ldots$

TABLES $\ldots \ldots \ldots \ldots \ldots \ldots \ldots \ldots \ldots \ldots \ldots \ldots \ldots \ldots \ldots$

ACRONYMS $\ldots \ldots \ldots \ldots \ldots \ldots \ldots \ldots \ldots \ldots \ldots \ldots \ldots \ldots \ldots \ldots \ldots$

EXECUTIVE SUMMARY $\ldots \ldots \ldots \ldots \ldots \ldots \ldots \ldots \ldots$ vii

1. INTRODUCTION $\ldots \ldots \ldots \ldots \ldots \ldots \ldots \ldots \ldots \ldots \ldots \ldots$

1.1 PURPOSE AND SCOPE $\ldots \ldots \ldots \ldots \ldots \ldots \ldots \ldots \ldots \ldots$

1.2 OVERVIEW $\ldots \ldots \ldots \ldots \ldots \ldots \ldots \ldots \ldots \ldots \ldots \ldots \ldots \ldots \ldots \ldots \ldots \ldots \ldots$

1.2.1 Logging Program Objectives $\ldots \ldots \ldots \ldots \ldots \ldots \ldots \ldots \ldots \ldots$

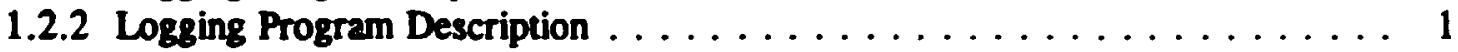

2. METHODOLOGY $\ldots \ldots \ldots \ldots \ldots \ldots \ldots \ldots \ldots \ldots \ldots$ 7

2.1 EQUIPMENT AND PROCEDURES $\ldots \ldots \ldots \ldots \ldots \ldots \ldots \ldots$

2.2 EQUIPMENT DECONTAMINATION $\ldots \ldots \ldots \ldots \ldots \ldots \ldots \ldots \ldots$

3. LOG EVALUATION $\ldots \ldots \ldots \ldots \ldots \ldots \ldots \ldots \ldots \ldots \ldots \ldots \ldots \ldots$

3.1 FRACTURE IDENTIFICATION $\ldots \ldots \ldots \ldots \ldots \ldots \ldots \ldots \ldots \ldots \ldots$

3.1.1 Diagnostic Log Responses . . . . . . . . . . . . . . 11

3.2 CHICKAMAUGA GROUP AND FRACTURE OCCURPENCE $\ldots \ldots \ldots \ldots 14$

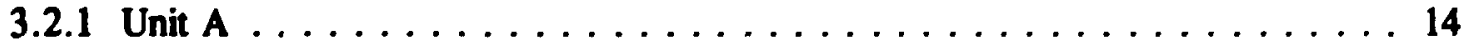

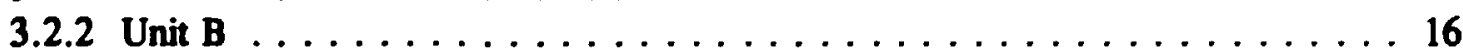

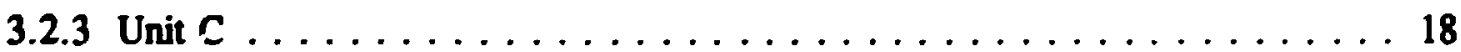

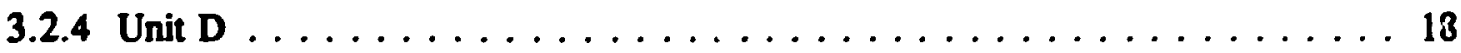

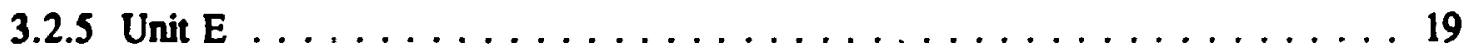

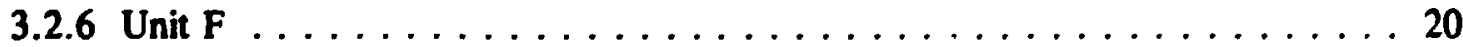

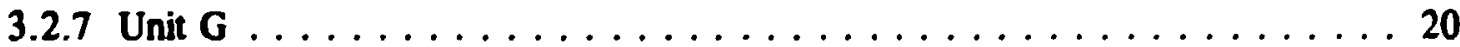

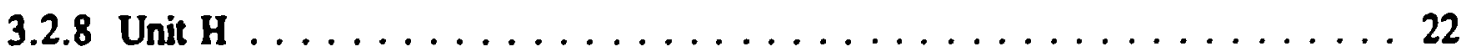

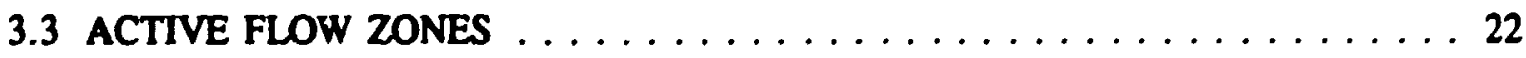

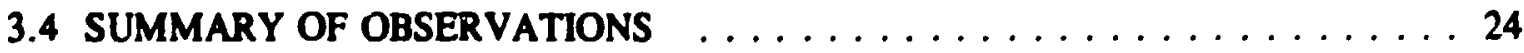

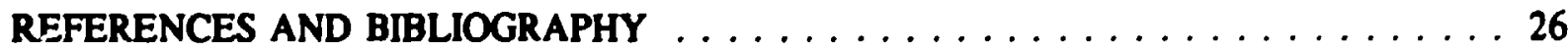

CH0O6-GEOPHYSICAL AND GEOLOGIC DATA $\ldots \ldots \ldots \ldots \ldots \ldots$ A-1-1

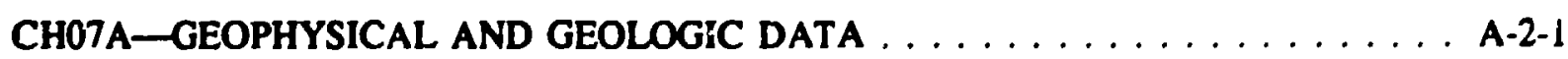

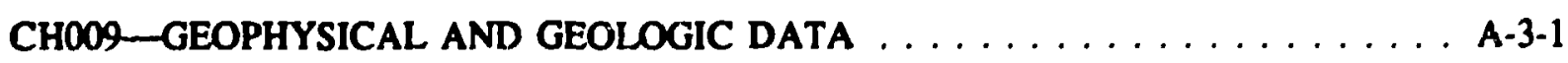

CH11A-GEOPHYSICAL AND GEOLOGIC DATA $\ldots \ldots \ldots \ldots \ldots \ldots$ A-4-1 
CHOI2-GEOPHYSICAL AND GEOLOGIC DATA $\ldots \ldots \ldots \ldots \ldots \ldots \ldots$. . . . .

FT10 - GEOPHYSICAL AND GEOLOGIC DATA .............. A-6-1 


\section{FIGURES}

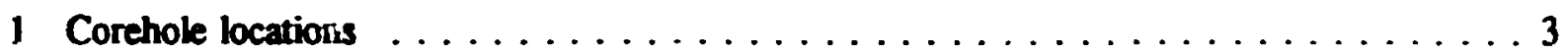

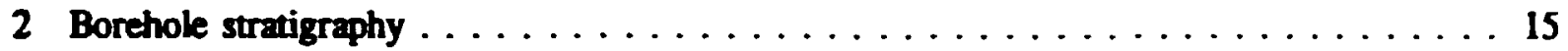

3 Occurrence of fractures and active fractures $\ldots \ldots \ldots \ldots \ldots \ldots \ldots \ldots$

\section{TABLES}

1 WAG 1 borehole information . . . . . . . . . . . . . . . .

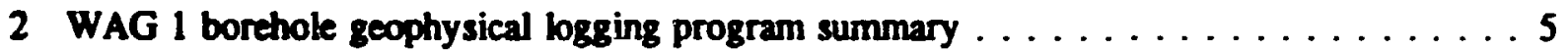

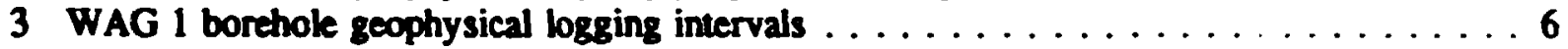

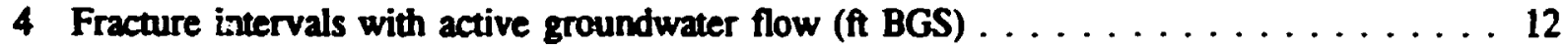




\section{ACRONYMS}

BGS below grounl surface

BHTV boreho!s televiewer

BNI Bechtel National, Inc.

ORNL Oak Ridge National Laboratory

QAQC quality assurance/quality control

RI

SP remedial investigation

SPR self-potenticl

TM single-point resistance

VDL technical memorandum

WAG variable density acoustic log waste area grouping 


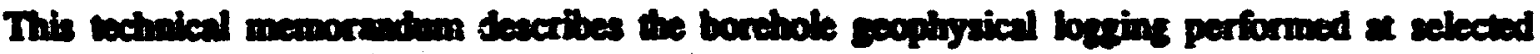
corcholes a Were Area Grovpins 1 between Merch and November 1991 in support of the remedid

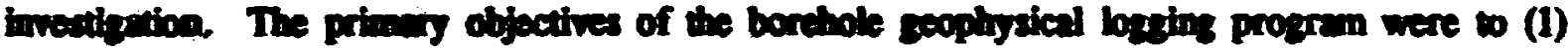

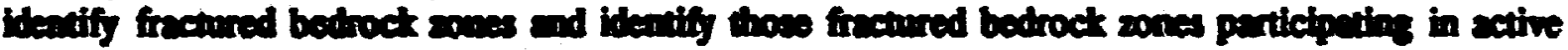

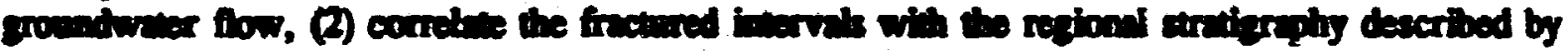

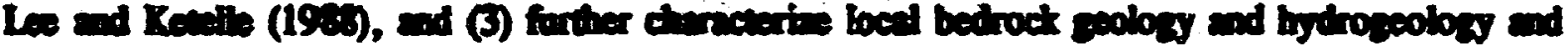

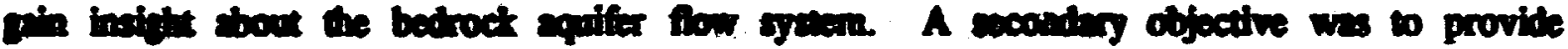

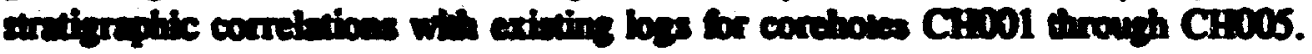

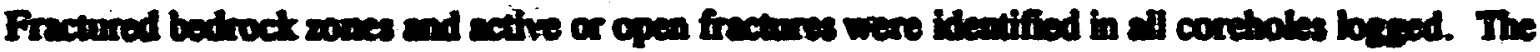

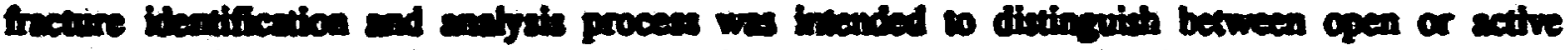

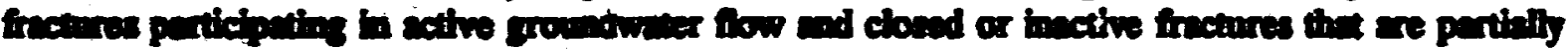

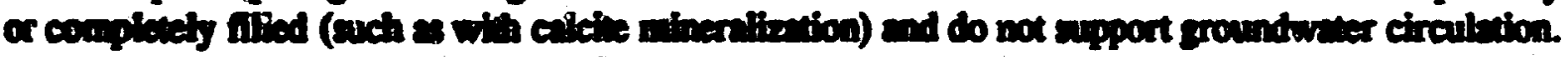

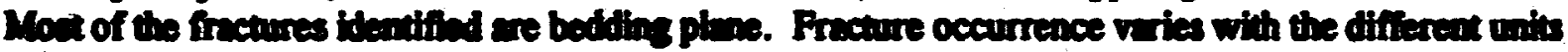

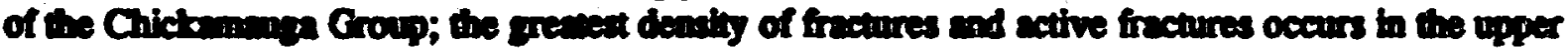
150 it of trume cored. Fractures actively contributing to groundwater fiow were also identified, and direction of foid movement within frectures was identified for those coreboles with flowmeter dan. 


\section{INTRODUCTION}

\subsection{PURPOSE AND SCOPE}

This technical memorandum (TM) documents the locations, methodology, equipment used, and results of the borehole geophysical logging performed on selected coreholes as part of the remedial investigation (RI) of Waste Area Grouping (WAG) 1. The results of this study will be used to help develop the conceptual model of groundwater flow at WAG 1, which in turn will be used to identify contaminant transport pathways.

This TM is organized into three sections and six attachments. The remainder of this section discusses the objectives of the logging program and summarizes the logging program as conducted. Section 2 describes specific log types, logging tools and equipment, logging procedures, equipment decontamination, health and safety measures, and data output format. Section 3 presents a discussion of findings based on evaluation of the borehole geophysical logs. Attachments 1 through 6 are the actual logs for each corehole logged; the Environmental Sciences Division at Oak Ridge National I aboratory (ORNL) maintains the raw data files for these logs.

\subsection{OVERVIEW}

\subsubsection{Logeing Program Objectives}

Five deep coreholes [generally 184 to $490 \mathrm{ft}$ below ground surface (BGS)] were drilled to assess groundwater quality, hydrogeology, and geology at depth within the bedrock aquifer. (Packer tests were also completed in these coreholes; results are reported under separate cover.) Following drilling, all five boreholes were geophysically logged. Corehole FT10, drilled by ORNL in the 1970s, was also logged.

The primary objectives of the borehole geophysical logging program were to (1) identify fractured bedrock zones and determine which fractures were participating in active groundwater flow, (2) correlate the fractured intervals with the regional stratigraphy described by Lee and Ketelle (1988), and (3) further characterize local bedrock geology and hydrogeology and gain insight about the bedrock aquifer flow system. A secundary objective was to provide stratigraphic correlations with existing logs for coreholes CHOO1 through CHOOS (Lee and Ketelle 1988).

The fracture identification and analysis process was intended is, disinguish between open or active fractures participating in active groundwater flow and closed $\mathrm{cr}$ inactive fractures that are partially or completely filled (such as with calcite mineralization) and do nor support groundwater circulation.

\subsubsection{Loesging Program Description}

Borehole geophysical logging was completed on five water-filled coreholes drilled in association with the WAG 1 RI (CH006, CH07A, CH009, CH11A, and CH012) and one corehole (FT10) 
drilled for a previous investigation. With the exception of FT10 and CH006, the coreholes are within the WAG 1 boundary. FT10 is northwest of WAG 1, approximately $50 \mathrm{ft}$ west of First Creek and north of West End Circle. Figure I shows the locations of the WAG 1 coreholes logged and the coreholes Lee and Ketelle (1988) used in defining the subsurface geology at ORNL. Plate 1 of their publication was used for stratigraphic correlation with the corcholes studied in this investigation.

Initially, it was intended that the corehcles would be cored to a depth not to exseed 500 ft and the full suite of geophysical logs would be run on the open coreholes using ORNL's logging capabilities. The criterion used to terminate drilling on a particular hole was a decrease in the number of fractures observed during drilling. Logging occurred intermittently from March 19 through November 7 , 1991. Table 1 summarizes pertinent location and borehole information for the six holes logged. ORNL performed borchole televiewer and deviation surveys to total depth on all six coreholes, with three exceptions. Deviation surveys were not performed on FT10 and CH012 because the inclinometer was out for repairs, and the borehole televiewer survey was only run to $138 \mathrm{ft}$ BGS on CH11A. Table 2 summarizes the scope of the logging program performed as part of the WAG 1 RI. Table 3 summarizes the intervals logged by ORNL.

No geophysical logs were run in CHOO8 because that hole was completed at a relatively shallow depth to allow for insiallation of a multiport well.

Ambient flowmeter surveys were run on $\mathrm{CH} 009$ and $\mathrm{CHO12}$ (Moore and Young 1991). Flow was measured through the length of the borehole through which it was anticipated, but not for the entire length of the borehole, as time constraints were imposed on use of the TVA equipment. Additionally, not all coreholes could be logged, due to denied access, corehole condition (e.g., suspected of containing natural oil), and schedule constraints. The opportunity to use the flowmeter was not part of the original scope of work, and investigators tried to $\log$ as much corehole as possible within the constraints of the equipment availability. 


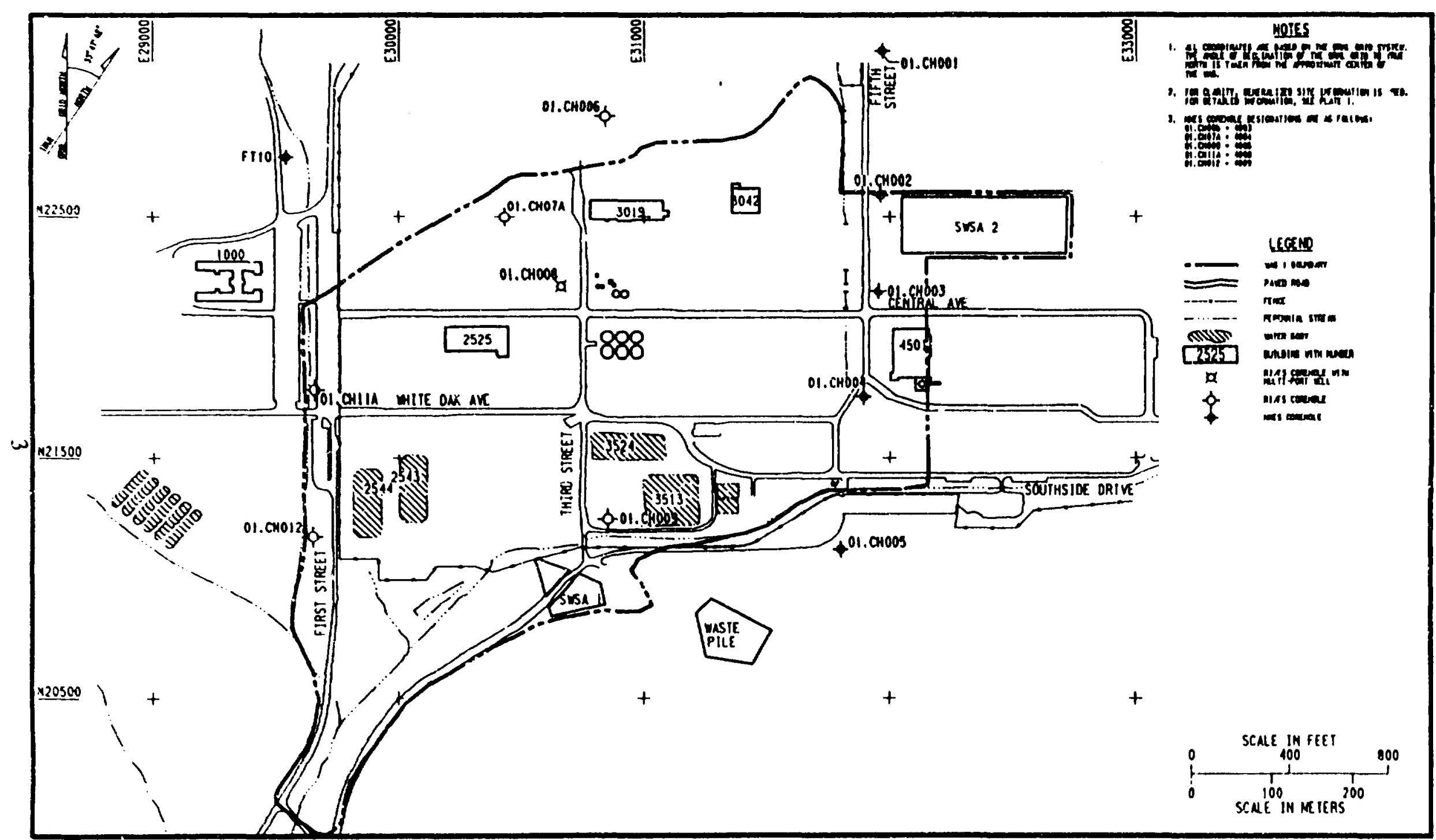


Table 1. WAG 1 borehole information

\begin{tabular}{|c|c|c|c|c|c|c|}
\hline \multirow[b]{2}{*}{ Corehole" } & \multicolumn{2}{|c|}{ ORNL grid location } & \multirow{2}{*}{$\begin{array}{l}\text { Ground } \\
\text { elevation } \\
\text { (ft) }\end{array}$} & \multirow{2}{*}{$\begin{array}{l}\text { Surface } \\
\text { casing } \\
\text { elevation' } \\
\text { (f) }\end{array}$} & \multirow{2}{*}{$\begin{array}{l}\text { Driller's } \\
\text { total } \\
\text { depthd } \\
\text { (fi) } \\
\end{array}$} & \multirow{2}{*}{$\begin{array}{l}\text { Surface } \\
\text { casing } \\
\text { depth } \\
\text { (ft) }\end{array}$} \\
\hline & $\begin{array}{l}\text { North } \\
\text { (f) }\end{array}$ & $\begin{array}{l}\text { East } \\
\text { (ft) }\end{array}$ & & & & \\
\hline СH0OS & 22919.02 & 30839.76 & 870.1 & 871.83 & 404.0 & 70.8 \\
\hline CH07A & 22499.99 & 30430.54 & 851.9 & 853.77 & 184.6 & 34.6 \\
\hline СHOOO & 21244.27 & 30850.47 & 781.3 & 784.80 & 404.7 & 17.0 \\
\hline CH11A & 21784.79 & 29656.75 & 786.6 & 788.98 & 282.5 & 15.3 \\
\hline CHO12 & 21171.97 & 29651.05 & 777.5 & 780.11 & 490.4 & 17.0 \\
\hline FT10 & 22750.55 & 29540.00 & 807.6 & 809.50 & 403.5 & 75.0 \\
\hline
\end{tabular}

Energy Systems designations for these coreholes:

CHOO6 $=4003$
CH07A $=4004$
CHOO9 $=4006$
CH11A $=4008$
CH012 $=4009$

'As measured at ground surface (not top of concrete pad).

'At time of logging.

Below ground surface. 
Table 2. WAG 1 borehole geophysical logging program summary

\begin{tabular}{|c|c|c|c|c|c|c|}
\hline \multirow[b]{2}{*}{ Log type } & \multicolumn{6}{|c|}{ Corebole } \\
\hline & CHOOS & CH07A & $\mathrm{CHOO9}$ & CH11A & $\mathrm{CH} 012$ & FT10 \\
\hline Natural gamma ray & $\mathbf{x}$ & $\mathbf{x}$ & $\mathbf{x}$ & $\mathbf{x}$ & $\mathbf{x}$ & $\mathbf{X}$ \\
\hline Caliper & $\mathbf{x}$ & $\mathbf{X}$ & $\mathbf{X}$ & $\mathbf{x}$ & $\mathbf{x}$ & $\mathbf{x}$ \\
\hline Temperature & $\mathbf{x}$ & $\mathbf{x}$ & $\mathbf{x}$ & $\mathbf{x}$ & $\mathbf{X}$ & $\mathbf{X}$ \\
\hline Differential temperature & $\mathbf{x}$ & $\mathbf{x}$ & $\mathbf{x}$ & $\mathbf{x}$ & $\mathbf{X}$ & $\mathbf{x}$ \\
\hline Self-potential & $\mathbf{x}$ & $\mathbf{x}$ & $\mathbf{x}$ & $\mathbf{x}$ & $\mathbf{x}$ & $\mathbf{x}$ \\
\hline Borchole televiewer & $\mathbf{x}$ & $\mathbf{x}$ & $\mathbf{x}$ & $\mathbf{x}$ & $\mathbf{X}$ & $\mathbf{x}$ \\
\hline Variable density acoustic log & $\mathbf{x}$ & $\mathbf{x}$ & $\mathbf{x}$ & $\mathbf{x}$ & $\mathbf{X}$ & $\mathbf{x}$ \\
\hline Short/long normal resistivity & $\mathbf{x}$ & $\mathbf{x}$ & $\mathbf{x}$ & $\mathbf{x}$ & $\mathbf{x}$ & $\mathbf{x}$ \\
\hline Single-point resistance & $\mathbf{x}$ & $\mathbf{x}$ & $\mathbf{x}$ & $\mathbf{x}$ & $\mathbf{x}$ & $\mathbf{x}$ \\
\hline Devintion survey & $\mathbf{x}$ & $\mathbf{x}$ & $\mathbf{x}$ & $\mathbf{x}$ & N/A & N/A \\
\hline 4-Pi density & $\mathbf{X}$ & $\mathbf{x}$ & $\mathbf{x}$ & $\mathbf{x}$ & $\mathbf{X}$ & N/A \\
\hline Neutron & $\mathbf{x}$ & $\mathbf{X}$ & $\mathbf{x}$ & $\mathbf{x}$ & $\mathbf{X}$ & $\mathbf{x}$ \\
\hline Sonic & $\mathbf{x}$ & $\mathbf{x}$ & $\mathbf{x}$ & $\mathbf{X}$ & $\mathbf{x}$ & $\mathbf{x}$ \\
\hline Borchole flowmeter & $\mathbf{N} / \mathbf{F}$ & N/A & $\mathbf{X}$ & $\mathbf{N} / \mathbf{F}$ & $\mathbf{x}$ & N/A \\
\hline
\end{tabular}

Notes:

X-Logging performed by ORNL.

N/A-Logging not performed.

N/F-Logging not performed due to overhead interference such as power lines or downhole interference such as installed packers. 
Table 3. WAG 1 borehole geophysical logeing intervala

\begin{tabular}{lllllll}
\hline & \multicolumn{5}{c}{ Corehole depth (A) } \\
\hline Log type & CHOO6 & CHO7A & CHOO9 & CHIIA & CHO12 & FT10 \\
\hline Natural gamma ray & $0.0-403.2$ & $0.0-183.4$ & $0.0-404.1$ & $0.0-281.2$ & $0.0-489.8$ & $0.0-400.3$ \\
Caliper & $53.1-402.6$ & $0.0-183.0$ & $0.0-403.9$ & $0.1-281.4$ & $0.0-490.4$ & $0.0-389.9$ \\
Temperature & $0.0-400.6$ & $0.0-181.2$ & $0.0-400.0$ & $0.0-283.7$ & $0.0-490.0$ & $0.0-403.5$ \\
Differential temperature & $1.0-399.6$ & $1.0-180.2$ & $1.0-399.0$ & $1.0-283.7$ & $5.0-485.0$ & $72.3-397.6$ \\
Self-potential & $0.0-403.2$ & $0.0-183.4$ & $0.0-404.1$ & $0.0-281.2$ & $0.0-485.4$ & $0.0-369.9$ \\
Borebole televiewer & $70-400$ & $50-180$ & $15-395$ & $13-138$ & $15-485$ & $80-390$ \\
Variable density scoustic log & $45.4-400.1$ & $46.0-180.0$ & $0.0-400$ & $3.4-279.1$ & $0.0-486.1$ & $72.8-397.6$ \\
Short/long normal resistivity & $77.9-402.7$ & $41.9-182.7$ & $31.4-400.1$ & $37.0-283.5$ & $29.4-490.4$ & $63.0-400.5$ \\
Single-point resistance & $41.9-399.7$ & $18.3-174.1$ & $0.0-405.1$ & $0.0-280.4$ & $0.0-480.3$ & $0.0-391.6$ \\
Deviation survey & $60-400$ & $0.0-182$ & $0.0-400$ & $0.0-280$ & N/A & N/A \\
4-Pi density & $29.8-401.8$ & $11.5-182.0$ & $0.8-401.6$ & $0.0-281.0$ & $0.0-488.8$ & N/A \\
Neutron & $28.7-402.2$ & $0.0-182.5$ & $0.0-402.3$ & $0.0-281.0$ & $0.0-489.0$ & $0.0-400.3$ \\
Sonic & $45.4-400.1$ & $46.0-180.0$ & $0.0-400$ & $3.4-2 / 9.1$ & $0.0-486.1$ & $72.8-397.6$ \\
Borehole flowmeter & N/A & N/A & $140-345$ & N/A & $20-330$ & N/A \\
Geologist's log & $0.0-404.0$ & $0.0-184.6$ & $0.0-404.7$ & $0.0-282.5$ & $0.0-490.4$ & N/A \\
\hline
\end{tabular}

Note: All depths showr are measured in feet below ground surface.

N/A-Log not prepared. $r$ run. 


\section{METHODOLOGY}

A full suite of geophysical logs was run en each opan hole as shown in Table 2, with exceptions as roted. The following paragranhe describe each method employed.

The natural gamma ray log measures naturally occurring gamma emissions (potassium, uranium, and thorium) associated with clay minerals present in the formation surrounding the borehole. Gamma ray logs are excellent indicators of shale content and, therefore, lithology and are widely used for correlation purposes. Gamma ray logs can be used with both cased and open boreholes.

Caliper logs record the average diameter (and shape) of the borehole with depth; the tool used was a three-arm summation caliper. Caliper logs are useful in confirming well construction, identifying bridging and washouts, locating large open fractures and other cavities, and c rrecting log responses from other tools.

The temperature log continuously records the temperature of fluids in the borehole as the tool is lowered. Temperature logs are widely used to identify water-bearing zones, liquid levels, fluid entry points, and zones of lost circulation encountered during drilling.

The differential temperature $\log$ is used to identify and graphically display minute temper ature anomalies that are often not apparent from the gradient temperature log displays. The slope of the temperature at each point is computed for a given spacing; 4-ft spacing was used for this log.

The self-potential (SP) log, also known as spontaneous potential, uses a graphic plot of the natural direct voltage potential differences measured between a downhole electrode and a fixed reference electrode at the surface. The SP log is measured in millivolts and is used to identify lithology, bed thickness, and formation water salinity.

The borehole televiewer (BHTV) log makes use of an acoustic tool that produces a $360^{\circ}$ view of the wellbore by measuring the minute changes in sonic wave amplitude caused by the lithology and discontinuities in the formation exposed in the borehole. The radial output image is magnetometeroriented so that bedding, fracture dip angle, and direction can be determined. Generally, fractures discordant to bedding are indicated by dark bands. Bedding plane fractures may be difficult to recognize. The BHTV data are recorded as a series of photographs.

The variable density acoustic log (VDL) is primarily used to identify fractured intervals; it can also be used as a cement bond $\log$ to assess annular grouting.

The short/long normal resistivity log (also known as 16-64 normal logs) measures shallow and deep voltage potentials at electrodes spaced at 16 in. and 64 in. from a current-emitting electrode in the tool to deiermine formation water quality. The short (16-in.) normal curve displays resistivity near the borehole, and the long (64-in.) normal curve records resistivity further from the borehole within the formation. 
The single-point resistance (SPR) log measures the apparent resistance of in sin materials (water and rock) in the borehole. Because SPR logging has a very small radius of investigation, it is very sensitive to changes in borehole fluid resistivity and hole diameter and can be used to identify formation discontinuities such as fractures or thin bed changes. For this reason, it is often used for determining stratigraphic boundaries and changes in lithology and identifying fractures in highly resistive bedrock.

The deviation (or directional) survey records borehole inclination and azimuths continuously against depth to determine how straight a borehole is and to determine the bottom hole location at total depth. Sharp deviations in the borehole may indicate changes in formation dip and faulting and fracturing.

The 4Pi density log, also known as the gamma-gamma density $\log$, measures the bulk density of the formation exposed in the borehole. It is not borehole-compensated. A detector in the tool counts the rate of backscattered radiation emitted into the formation from a cesium-137 source within the tool. The bulk density of the formation is proportionally related to the attenuation and backscattering of the gamma photons by the formation. This tool is widely used for lithology determinations in coreholes.

The neutron log measures the hydrogen ion concentration in the exposed formation. A detector in the tool measures the attenuation and backscaliering of neutrons emitted from an americium and beryllium (Am/Be) source within the tool by hydrogen ions present in the formation. In water-filled holes, the neutron $\log$ measures fluid-filled porosity (often considered as total porosity) and rock composition. Above the water iable, the neutron $\log$ is used to measure moisture content. Neutron logs can be used in both cased and open boreholes.

The sonic or acoustic velocity $\log$ measures the transmission rate and attenuation of pulsed acoustic energy transmitted through the borehole fluid and adjacent rocks. The attenuation of the sonic signal is related to the porusity and lithology of the formation. Because sonic wave propagation through the formation is confined to solid rock, vugs and fractures are bypassed. Cycleskipping is caused by excessive signal attenuation by formation, fracture, and/or fluid discontinuities or equipment malfunctions. Typically, cycle-skipping is interpreted as an indicator of fracturing.

ORNL performed a borehole flowmeter survey for two of the coreholes (Moore and Young 1991). These surveys measure flow within the coreliole at the ambient natural gradient. The flowmeter device, which consists of two chloride electrodes and a magnetic coil inside a hollow cylinder, measures the interaction of the conductor and magnetic field as a voltage. To complete the circuit, some dissolved solids in the fluid being measured are necessary. A positive voltage measurement indicates flow up the hole.

The geologist's $\log$ included a description of iractures per foot. A plot of these fractures with depth was prepared for all coreholes installed by the Bechtel Team. A broad interpretation of fractures was used in preparing the geologist's log. Project Procedure 1643, "Rock Coring," defines fracaures as "core separations along any discontinuity (joints, bedding, faults, foliation) in the rock mass." Care was taken not to count mechanical breaks from drilling or sleeve handling as fractures. 


\subsection{EQUIPMENT AND PROCEDURES}

ORNL, used truck-mounted logging rigs with on-board microcomputers capable of providing onsite data processing. All tcols were stored in tubes contained within the logging rig. All sources were tightly controlled and (when not in use) were stored in locked pigs (radioactive transport shield) mounted within the logging rigs. Long handling tools were used to insert and remove the $\mathrm{Am} / \mathrm{Bc}$ and cesium-137 sources. ORNL logging equipment usau a 3-Ci Am/Be-241 neutron source and a 125-mCi cesium-137 gamma source.

All logging was performed in accordance with standard ORNL logging procedures in effect the time. Before the six deep coreholes were logged, the ORNL logging unit was used to log CHOO2, located within the main plant area and designated the calibration hole for all borehole logging on the Oak Ridge Reservation.

With the exception of the BHTV logs, all geophysical logs were digitally recorded in increments of $0.10 \mathrm{ft}$. The berehole geophysical logs were produced as hard copies, and log data were provided in digital (ASCII) form.

Several runs were required to complete the full logging suite shown in Table 2. Logging tools were generally run in the following order: temperature/differential temperature (downhole); natural gamma ray; SD: caliper; resistivity; sonic; neutron; gamma-gamma density; long/short normal resistivity; BHTV; and deviation survey.

Temperature and differential temperature logs were recorded first to minimize disturbance of the ambient tempsrature profile by multiple trips of the logging tools. Temperanure and differential temperature were recorded at a rate of $5 \mathrm{ft} / \mathrm{min}$ as the first tool was lowered into each borehole, except that the differential temperature for FT10 was recorded at a rate of $7 \mathrm{ft} / \mathrm{min}$. Sufficient time (e.g., a minimum of 5 days for CH11A, but more typically 3 weeks or more) had elapsed between the completion of corehole drilling and borehole logging to allow the borehole temperature to reach equilibrium.

All other logs were run uphole as sach too! was removed from the borehole. Uphole logging was performed at a rate of 7 to $18 \mathrm{ft} / \mathrm{min}$; the most common logging speed was $15 \mathrm{ft} / \mathrm{min}$. The sonic and vas able density logs were run at 7 to $8 \mathrm{ft} / \mathrm{min}$.

BHTV photos were obtained for each 5-ft interval, composited as a single log, and reproduced with depth annotations.

Flowmeter logging was performed by setting a packer around the interval to be testec so that all flow passed through the center hole in the flowmeter (Moore and Young 1991). The packer had to be reset each time a new interval was tested. Logging was terminated when the flow dropped off dramatically with depth. Flowmeter logging occurred in October and November 1991.

Coreholes were logged approximately in the order in which they were finished. However, FT10, drilled in the 1970s, was logged last, after fluid was circulated in the borehole to clean it out. 


\subsection{EQUIPMENT DECONTAMINATION}

The decontaminatim procedure consisted of collecting and analyzing wipe samples of the probes and cable between coreholes and, if no contamination was deiected, moving on to the next corehole. If contamination was detected, the rig and all equipment would be steam cleaned/decontaminated in accordance with Project Procedure 1250, Equipment Decontamination and Release for Unrestricted Use."

As the tools were removed from the borehole, they were wrapped in plastic sleeves, taped shut, and staged on plastic sheeting until logging was completed for each well. Upon completion of the loeging, all tools were wipe-sampled and returned to the tool storage ubes on the logging rig if clean.

When the nuclear source tools were removed from the borehole, the external casings of the cesium-137 and Am/Be sources were cleaned using a laboratory detergent and water wash and distilled water rinse while still attached to the tool. The sources were then quickly removed from the tool and returned to the pig using a long-handled tool. Total exposure time was minimal (45 to $60 \mathrm{~s}$ ). 


\section{LOG EVALUATION}

Borehole geophysical logs for coreholes CH006, CH07A, CH0O9, CH!IA, CH012, and FT10 are included as Attachments 1 throigh 6, respectively. For eac.. corehole, the logging data are presented in the following order: summary table of fractures identified, composite figure of geophysical logs and fracture intervals, VDLs, BHTV logs, deviation surveys, and (for $\mathrm{CHOO9}$ and CH012) flowmeter data and graphs.

In fulfillment of the scope of the objectives for borehole geophysical logging, logs run for this study were evaluated to icentify fracture intervals and water-bearirg fracture zones, to provide further insight regarding the hydrogeologic system, and wo provide correlations with other logged wells in WAG 1 (Lee and Ketelle 1988).

\subsection{FRACTURE IDENTIFICATION}

\subsubsection{Diagnostic Log Responses}

Fractures were first identified using the geologist's log, the BHTV, and the VDL. Interpretation of the VDL was based on subjective observation of signal disintegration. The fractures were then characterized by one or more diagnostic log responses.

Of the geophysical logs available, the most useful for identifying active fractures were the temperature and differential temperature logs and the available flowmeter logs. Shifts in the temperature logs, especially if the shifts coincided with a shift in the caliper log, were used as presumptive indications of open fractures supporting groundwater -irculation; peaks in the differential temperature logs were also used as indications of fluid entry. The geologist's logs were consulted tc check for any notation concerning calcite mineral in filling of the fracture(s) noted at that depth.

Those intervals displaying temperature and differential temperature log responses supported by other log responses were interpreted as significant active or open fractures. When flowmeter data were available, fluid entry or exit through the fractures could be identıfied, provided that a sufficient head differential existed to drive flow; without the flowmeter data, only fluid movement could be identified. Active fracture intervals are identified in Table 4.

The sonic log and the inverse of the neutron log are related to lithology in that their traces are near-perfect overlays of the lithologically controlled gamma ray trace; therefore, they did not provide additional data on fracture occurrence and characteristics. The inverses of the sonic log and the SPR, SP, and neutron logs were in many cases nearly identical and thus did not provide much additional information.

Borehole televiewer. Fractures were readily identifiable on BHTV photo logs as dark bands that generally followed dip and bedding features. BHTV logs were available for all coreholes except CH11A (BHTV available only to $138 \mathrm{ft}$ BGS). The BHTV-identified fractures correlated well with 
Table 4. Fracture intervals with active groundwater now (ft BGS)

\begin{tabular}{|c|c|c|c|c|c|}
\hline \multicolumn{6}{|c|}{ Corchole } \\
\hline CHOOS & FT10 & CH07A & CH11A & СHCOS & CH012 \\
\hline $50-52$ & $50-54$ & $37.6-41.6$ & $23-27$ & $33-37$ & $30.4-33.4$ \\
\hline $61.8-63.8$ & $85-88$ & $50-59.1$ & $28-35$ & $45-48$ & $34.4-37.4$ \\
\hline $70.8-75.8$ & $93-96$ & $64.1-67$ & $39-42$ & $54-58$ & $44.4-46.4$ \\
\hline $82-90.8$ & $102-106$ & $69.1-73.1$ & $43-46$ & $59-54$ & $65-68.4$ \\
\hline $92.8-94.8$ & $112-116$ & $76.1-79.1$ & $48-5 i$ & $66-68$ & $86-88.4$ \\
\hline $98.8-108.5$ & $120-122$ & $82.1-88.1$ & $63-67$ & $70-72$ & $95-97$ \\
\hline $124.5-127.5$ & $141-143$ & $89.1-92.1$ & $83-87$ & $75-79$ & $10 i-103$ \\
\hline $128-5-135.1$ & $160-164$ & $93.1-98$ & $94-98$ & $85-89$ & $126-129.2$ \\
\hline $136.1-140.5$ & $168-172$ & $109-113$ & $101-104$ & $94-97$ & $141-145$ \\
\hline 144.1-152 & $173-186$ & $125-9-128.9$ & $112-115$ & $98-100$ & $151-154.2$ \\
\hline $157-163$ & $186-190$ & $129.9-131.9$ & $120-123$ & $123-125$ & $181-183$ \\
\hline $1661-171.1$ & $192-196$ & $133-136.9$ & $124-130$ & $129-133$ & $228.1-230.1$ \\
\hline $198.1-200.1$ & $200-207$ & $137.9-139.9$ & $141-143$ & $146-148$ & $249-251$ \\
\hline 217.1-219 & $214-218$ & $155-158.6$ & $23 i-234$ & $150-154$ & $260-262$ \\
\hline $223.1-225$ & $236-241$ & $160.6-169.6$ & $278-290$ & $158-161$ & $286-289$ \\
\hline $226.1-229$ & $249-253$ & & & $179-183$ & $299-304.7$ \\
\hline $247.4-252.4$ & $259-265$ & & & $195-198$ & $319.7-322.7$ \\
\hline $294-297$ & $273-277$ & & & $211-214$ & $332.7-337$ \\
\hline $323-327$ & $293-299$ & & & $237-240$ & $377.7-379.7$ \\
\hline \multirow[t]{4}{*}{$386-389$} & $306-312$ & & & $258-261$ & $412.7-415.7$ \\
\hline & $319-3.22$ & & & $332-334$ & $440.4-444.4$ \\
\hline & $345-349$ & & & & $463-468$ \\
\hline & $36 c-363$ & & & & $481.4-485.4$ \\
\hline
\end{tabular}


the fractures noted in the geologist's logs. The dark bands apparent on the BHTV photos reflect toth healed (mineral-filled) and open fractures, but this determination could not be made from the BHTV logs. Comparison with the geologist's logs showed that most of the fractures were open.

Variable density acoustic log. Fractured intervais were readily identifiable on the VDL bec- $₹$ the third and fourth waveforms attenuated in fractured intervals. These logs correlated well with ..: geologist's logs and the BHTV and provided useful confirmation. They were also useful :ai determining the overall fractured nature of individual units of the Chickamauga Group and . different lithologies identified within the units (Lee and Keielle 1988).

Temperature. Temperature anomalies were identified as distinct spikes and baseline shifts in the normal temperature gradient. In some cases, rather than increasing with depth, the temperature showed marked cooling with depth before returning to gradient. Temperature responses (indicating fluid entry points) generally displayed good correlation with BHTV and VDL.

Difierential temperature. Differential temperature responses were identified as distinct spikes that correlated with the BHTV and VDL log responses and often with the caliper and deviation survey responses.

The software package Grapher was used to expand the horizontal scale for both temperature and differential temperature logs. Expanded scales more clearly showed subtle shifts in temperature or differential temperaure peaks that may not be apparent on the smaller scale of the figures in the attachments.

Coliper. Individual open fractures can sometimes be identified using caliper logs. Caliper increases, in part, confirmed other log responses to fracturing and were principally used as secondary evidence.

Self-potential. In intervals identified as fractured using other log responses, SP signatures generally showed sharp but minor decreases followed by an increase. In some cases, large baseline shifts no. readily associated with lithology were noted; these shifts correlated well with temperature anomalies.

Single-point resistance. In massive resistive rocks, SPR anomalies are usually seen as sharp decreases in ohms. Because of the interbedded nature of the bedrock at WAG 1 , fracture anomalies were not discernible.

Fractures per foot. The fractures-per-foot log, available for all coreholes but FT10 (which has no geologist's log) showed a response that was generally correlatable to lithology when used in conjunction with other geophysical evidence. The fractures-per-foot log was prepared by the on-site geologist on the basis of visual inspection ard measurement of the fractures in the core. Fractures that appeared very fresh or exhibited other features indicating that they may have been caused by the drilling process were not counted for the fractures-per-foot log.

Borehole nowmeter survey. Ambient flowmeter surveys are available for $\mathrm{CH} 009$ and $\mathrm{CH} 012$ for the approximate interval between 20 and $340 \mathrm{ft}$ BGS. The 223- to 338-ft interval had upward 
flow in $\mathrm{CHOO9}$ (ranging from 0.084 to $0.161 \mathrm{gpm}$ ), and the 60 - to 302 -ft interval had upward flow in $\mathrm{CHO} 12$ (sanging from 0.091 to $0.124 \mathrm{gpm}$ ). About $80 \%$ of the depth intervals measured that had upward flow also had fractures noted on either the geologist's log, the BHTV log, or the VDL. However, not all intervals with numerous fractures were noted as increased upward flow on the flowmeter log.

Deviation surveys. When used in conjunction with other logs, deviation surveys were useful in some cases for confirming fractured intervals. In many cases, the same depth interval would show as fractured on more than one plot for a particular corchole.

\subsection{CHICKAMAUGA GROUP AND FRACTURE OCCURRENCE}

All the coreholes drilled for this study penetrated the middle Ordovician Chickamauga Group, which consists generally of interbedded limestone and siltstone. The eight mappable units of the Chickamauga Group (Units A through $\mathbf{H}$ as described in subsequent sections), as defined by Stockdale (1951) and slightly modified by Lee and Ketelle (1988), are used in this TM. Unit A is the oldest and Unit $\mathbf{H}$ is the youngest penetrated. Figure 2 shows the units penetrated in each corehole. To facilitate comparisons among cores and between cores and geophysical logs, thicknesses reported from both this study and Lee and Ketelle (1988) are structural thicknesses in downhole $\mathrm{ft}$ BGS, as opposed to bedding thickness.

\subsubsection{Unit A}

Lee and Ketelle (1988) characterize Unit A (penetrated only in CHOO1 in their study) as consisting of thick, intertedded sections of calcareous siltstone and calcarenite and as one of the most lithologically diverse units of the Chickamauga Group. In this study Unit A was penetrated in CHOO6 (at depths ranging from $327 \mathrm{ft}$ to the total corehole depth of $404 \mathrm{ft}$ ) and in FT10 from 366 $\mathrm{ft}$ to the total corehole depth of $403.5 \mathrm{ft}$. In $\mathrm{CHOO6}$. Unit A consists of silty, fine-to-medium-grained, fossiliferous limestone with chert nodules and beds and calcareous siltstone, which exists as stringers to medium beds.

Unit $A$, easily identified on the gamma ray log, is represented by a sharp drop in the gamma ray count from an average of $50 \mathrm{cps}$ in Unit $B$ to an average of $25 \mathrm{cps}$. The gamma ray traces of the upper 55 to $60 \mathrm{ft}$ of Unit A in FT10 and CH006 correlate very well, and muderately well with the composite log of Unit A in CHOOI [Plate 1 of Lee and Ketelle (1988)].

Unit $A$ is relatively unfractured compared with the other units penetrated during this study. Fractures noted in the geologist's log for $\mathrm{CHOOC}$ were predominantly bedding plane fractures (dips of $24-40^{\circ}$ south, based on the ORNL grid system), followed by two dip-normal fracture sets and one high-angle fracture surface. Calcite mineral ingrowth of the fractures was noted ir many cases, and fracturcs ranges from slightly open to tight. The fractures-per-foot log for $\mathrm{CH} 006$ shows more unfractured intervals in Unit A and fewer fractures per foot than the overlying Unit B. The VDL logs for both FT1O and CHOO6 also show thicker unfractured intervals and smalli:r fractured intervals. An example of a fractured interval is the 300- to 306-ft interval in the VDL for CHCO6. The BHTV logs for both $\mathrm{CHOO6}$ and FT10 show the relative absence of fractures- the superior quality of the CHOC6 log most graphically displays the unfractured nature of the formation. 


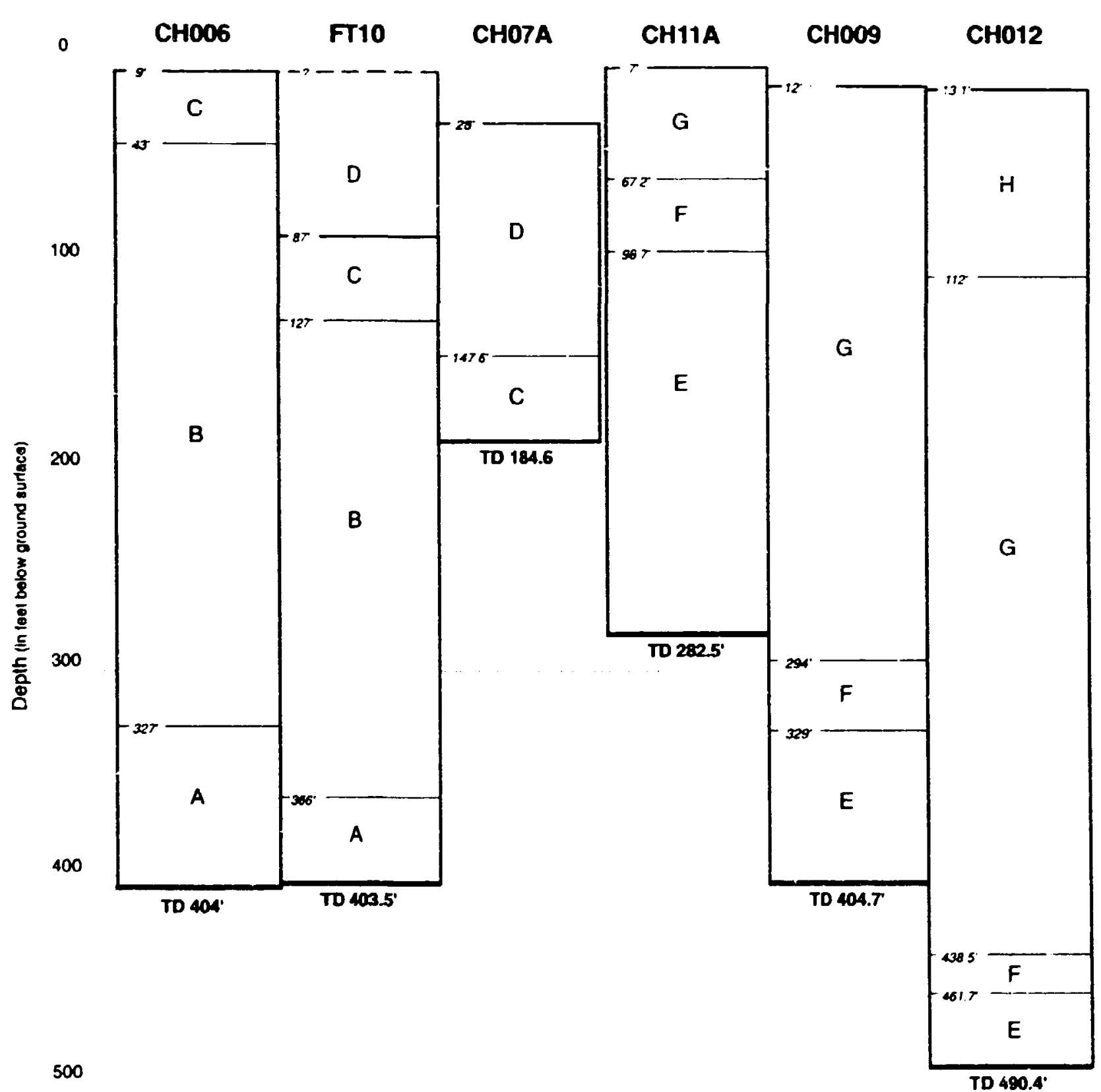

A through $\mathrm{H}=$ Units of Chickamauga Group (Slockdale. 1951)

Fig. 2. Borehole stratigraphy. 
Other evidence for fracturing found on the caliper, temperature, differential temperature, SP, and deviation surveys is presented by corehole in Tables A1.1 and A6.1. A summary of the fracture intervals, including the active fractures, found in both coreholes is presented in Fig. 3; Table 4 shows depth intervals of the active fractures supporting groundwater circulation. Both Fig. 3 and Table 4 were derived from Tables Al.1 through A6.1 by arbitrarily excluding fractured intervals of $1 \mathrm{ft}$ or less and by considering the preponderance of evidence in the tables before deciding if a fracture was actively supporting groundwater circulation. Unit A has relatively few fractures, and relatively few of those are active, based on the infrequent, slight shifts in the temperature and differential $\log$ responses and on the numerous notations of calcite infilling in the geologist's log for CHOO6.

\subsubsection{Unit B}

Unit B, penetrated in CHOO1 and CHOO2 of Lee and Ketelle (1988), is characterized in general as a massive, maroon, calcareous, and shaley siltstone with many fine- to medium-grained calcarenite beds. In this study Unit B is penetrated at depths of 43 to $327 \mathrm{ft}$ in CH006 and from 127 to 366 i in FT10. The geologist's log for CH006 describes the unit as "predominantly a massive bedded, calcareous, maroon siltstone with several light gray, fine- to medium-grained limestone beds."

Unit B has a distinctive gamma ray trace that is correlatable between CH006, FT10, and the composite log of Lee and Ketelle (1988). The gradually increasing silt content in the upper 30 to $35 \mathrm{ft}$ of the unit is shown on the gamma ray trace as a gradually increasing gamma ray count (beginning at 15 to $20 \mathrm{cps}$ ) that remains at an average of $50 \mathrm{cps}$ for the remainder of the unit. The massive nature of the unit is reflected in the generally consistent nature of the gamma ray trace.

Unit $B$ is one of the more fractured units encountered in this study; fractures per foot range from none to seven. Dip-normal fracture sets were found more frequently in the upper $100 \mathrm{ft}$ of this unit than in any other unit in this study and were typically slightly open to open. Low-angle fracture surfaces were more common in the lower portion of the unit and were usually open. Bedding plane fractures were the most frequently occurring and were generally slightly open to open with no calcite infilling.

Different types of fractures are not distinguishable on the VDLs for CHCO6 and FT10, but the pattern of fracturing is. VDLs from buth coreholes show consistent fracturing throughout the thickness of the unit, with fractured and unfractured intervals interlayered. The BHTV logs show the same pattern of intermixed fractured and unfractured interva's. A typical example is found in the interval between 95 and $135 \mathrm{ft}$ in CHOO6 on the BHTV. Fractures are visible in discrete zones between 99 and 102 q, 105 and $107 \mathrm{ft}, 113$ and $115 \mathrm{ft}$, and 128 and $133 \mathrm{ft}$. The rock between these zones is relatively free of fractures.

Tables A1.1 and A6.1 summarize the other evidence for fracturing and for identifying the open fractures, and Fig. 3 shows the distribution of the fractured intervals. The active fractures in Unit B occur throughout the unit but appear to be slightly more prevalent in its upper portion (Table 4). The lack of calcite mineralization noted on the geologist's $\log$ and the frequent temperature and differential temperature shifts were the principal criteria lised to determine which fractures were supporting groundwater circulation. 


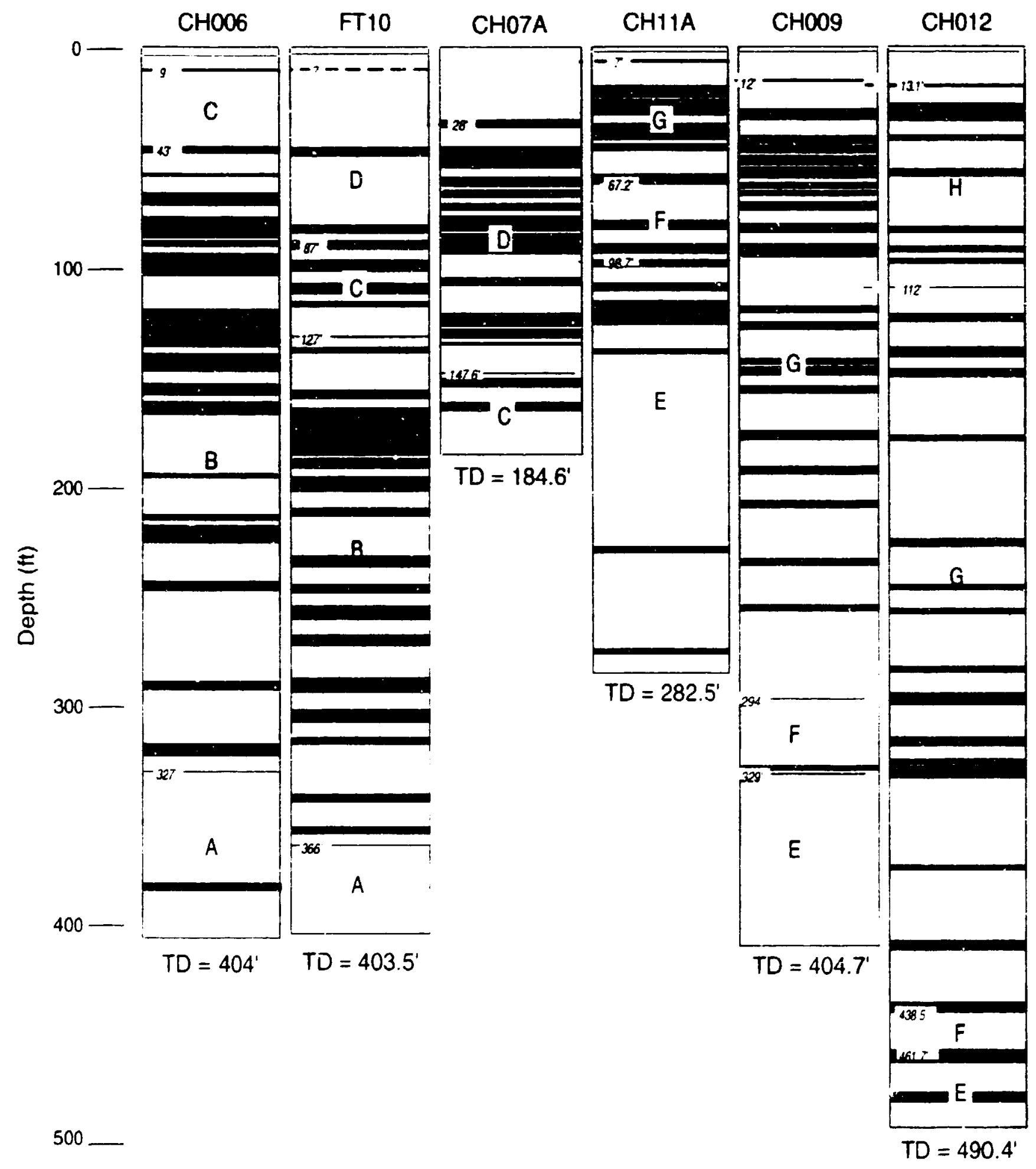

A through $\mathrm{H}=$ Units of Chickamauga Group (Stockdale. 1951)

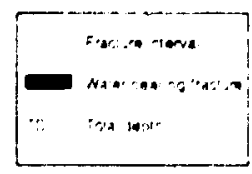

Fig. 3. Occurrence of fractures and active fractures.

17 


\subsubsection{Unit C}

Approximately $40 \mathrm{ft}$ of Unit C occur in CH006, FT10, and CH07A, ranging in depths from 9 to $43 \mathrm{ft}, 87$ to $127 \mathrm{ft}$, and 147.6 to $184.6 \mathrm{ft}$, respectively. Lee and Ketelle (1988) describe Unit C as interbedded fine-to medium-grained, stylolitic, unfossiliferous, crystalline calcarenite, and dark gray calcareous sitstone; small chert nodules are common. The geologist's log for $\mathrm{CH} 006$ describes Unit C as a massive bedded, fine- to medium-grained, hard, stylolitic limestone with some thin beds of sikstone and some cherty zones in the lower portions of the unit. In contrast, Unit C in CH07A is interbedded siltstone and limestone; the siltstone consists of 50 to $75 \%$ of the interval, and the limestone contains chert beds and nodules.

The gamma ray traces for $\mathrm{CHOO6,} \mathrm{CH07A,} \mathrm{and} \mathrm{FT10} \mathrm{and} \mathrm{the} \mathrm{composite} \mathrm{log} \mathrm{in} \mathrm{Lee} \mathrm{and} \mathrm{Ketelle}$ (1988) correlate only partially, due in part to the variable lithology and to different portions of the unit occurring in each corehole. The gamma ray traces for CHOO6 and CH07A seem to correlate with the lower unit shown on Plate 1 of Lee and Ketelle. The FT10 gamma ray log correlates only moderately well with the other data.

Unit $C$ is moderately fractured, with the fractures ranging from none to five per foot. Most fractures are of bedding plane type, ranging in dip from $26^{\circ}$ to $39^{\circ}$ from horizontal and ranging from tight to open. The VDLs for the three coreholes show evidence of fracturing, but it is not possible to correlate among the corcholes for this unit with this log. The BHTV logs for CH07A and FTIO verify that most of the fractures are the bedding plane type.

Tables A1.1, A2.1, and A6.1 summarize the other geophysical evidence for fracturing and for identifying the active fractures, and Fig. 3 shows the distribution of the fractured intervals. The fractures contributing to groundwater flow in Unit C occur more frequently in FT10 (Table 4) based on a comparison of the number of fractures occurring within Unit $C$ for the three coreholes. No calcite was noted on the geologist's log, and the frequent temperature and differential temperature shifts were the principal criteria used to assess which fractures were active.

\subsubsection{Unit D}

Unit $D$ is comprised of diverse limestone lithologies such as dense, medium-grained, stylolitic calcarenite; bird's-eye micrite; and nodular limestone. Bedded and nodular chert frequerclly occurs as a distinctive feature (Lee and Ketelle 1988). In this study Unit $\mathrm{D}$ is found in FT10 (to a depth of $87 \mathrm{ft}$; the upper contact is not known) and in CH07A (from 28 to $147.6 \mathrm{ft}$ ). The limestone litholngies noted on the geologist's log include thin to massive-bedded, micritic-to medium-grained, nodul ar and fossiliferous, with stylolites, chert nodules, and thin cher beds. Thinly bedded siltstone, biotuibated, soft and fresh, also occurs in the upper portion of Unit D.

The gamma ray trace for Unit D is a characteristic pattern of upper and lower intervals of low gamma ray counts with the middle portion of the trace containing two distinctive peaks. The most complete pattern for the unit is found on Plate 1 of Lee and Ketelle (1988) and on CH07A, which correlate well. Unit $D$ is the uppermost unit encountered in FT10; based on the correlation between this gamma ray trace and the 70- to 145 - $\mathrm{ft}$ interval in CH07A, only the lowermost portion of Unit $D$ is encountered in FT10. 
Unit $D$ is moderately fractured in FT10 and contains numerous fractured intervals in CH?7A. Fractures range from none to seven per foot in CH07A. Most fracures are bedding plane (dips of $24^{\circ}$ to $37^{\circ}$ south) ranging from slightly open to tight. A few other types of fractures are noted, such as low- and high-angle and dip-normal fractures, some of which are partially healed and almost filled with calcite crystais. At approximately $90 \mathrm{ft}$, a 1-ft cavity was encountered.

Two strong fracture intervals shown on the VDL for CH07A (66 to $69 \mathrm{ft}$ and 89 to $91 \mathrm{ft}$ ) correspond to intervals of high fractures per foot (three to six) on the geologist's log. The BHTV $\log$ for CH07A clearly shows these strongly fractured intervals and also shows that the frequency of fractures decreases with depth. Only $7 \mathrm{ft}$ of BHTV log were photographed for FT10.

Tables A2.1, A4.1, and A6.1 summarize the other evidence for fracturing and for identifying the open fractures; Fig. 3 shows the distribution of the fractured intervals. Most of the fractures in Unit $D$ in CH07A are active, and more active Unit D fractures occur in CH07A than in the other two coreholes that penetrated Unit D. This is based on the relatively prominent baseline shifts in the CH07A temperature log, the strong peaks on the differential temperature log, and the relative lack of calcite filling or healing of the fractures.

\subsubsection{Unit E}

Unit E was partially to totally penetrated in CH11A (98.7 to a total depth of $282.5 \mathrm{ft}$ ), CH009 (329 to total depth of $404.7 \mathrm{ft}$ ), and CH012 (461.7 to $490.4 \mathrm{ft}$ ) in this study. Unit E was also encountered in CH008, which was not logged. As described by Lee and Ketelle (1988), the unit is $350 \mathrm{ft}$ thick; due to its diverse nature, it is divided into three separate lithologies. The middle and upper lithologies of Lee and Y.etelle are represented in CH1 1A. They describe the middle lithology (about $56 \mathrm{ft}$ thick) as consisting of unfossiliferous siltstone with light gray limestone laminae, and the geologist's log from the interval 194 to $245 \mathrm{ft}$ in CH11 A describes a shale with thin, light-gray limestone interbedding. A massive, fine- to medium-grained calcarenite characterizes the uppermost lithology of Lee and Ketelle; the interval from 98.7 to $194 \mathrm{ft}$ in CH11A consists of limestone with shale partings and stringers.

The gamma ray log for CH11A correlates well with the composite gamma ray log from Lee and Ketelle; the peak patterns of the middle and upper lithologies are clearly matched on the two traces. Based on the strong correlation between the gamma ray traces of $\mathrm{CHO09}$ and $\mathrm{CH} 11 \mathrm{~A}$, only the upper $75 \mathrm{ft}$ of the upper lithology of Unit $\mathrm{E}$ were represented in CHOO9 before total depth was reached. In CH012, only the upper $30 \mathrm{ft}$ of Unit E were penetrated before total depth was reached.

Unit $E$ is a poorly to moderately fractured unit, and most of the fractures occur in its upper limestone member. However, in CHOO8 up to seven fractures per foot were identified in Unit E. Fractures most commonly range from none to three per foot and are bedding plane fractures $\left(25^{\circ}\right.$ to $37^{\circ}$ south) that are slightly open to open. In CH11A, few bedding plane fractures had any evidence of calcite minerals and very few were tight. In $\mathrm{CH} 009$ and $\mathrm{CH} 012$, the hedding plane fractures (dip $23^{\circ}$ to $45^{\circ}$ south) were generally noted as tight in the upper portions of the unit but with no evidence of calcite mineral. 
The VDLs for Init E show sequences of undisturbed rock interlayered with thicknesses of fractured rock. An example of this pattern can be seen on the VDL for CH11A in the intervals from 119 to $122 \mathrm{ft}$ and 141 to $143 \mathrm{ft}$ (disturbed) and from 122 to $141 \mathrm{ft}$ (undisturbed). This pattern is reasonably apparent in the portion of Unit E in CHIlA BHTV logs available, while the BHTV log for CHOO9 shows the decreasing fracture frequency with depth in this unit.

Tables A3.1, A4.1, and A5.1 summarize the other evidence for fracturing and for determining the active fractures; Fig. 3 shows the distribution of the fractured intervals. Most of the fractures in the upper lithology of Unit $E$ in CHI1A are open, and most active Unit E fractures occur in CH11A. This is based on the relatively prominent shifts in the CH11A temperature $\log$ (e.g., at approximately 85. 103, and $175 \mathrm{ft}$ ), the strong peaks on the differential temperature log, the relative lack of calcite filling or healing of the fractures, and the notation in the geologist's log that most of the fractures were open.

\subsubsection{Unit F}

Unit F is a laminated, maroon, calcareous, and shaiey siltstone with thinly bedded limestone and argillaceous limestone (Lee and Ketelle 1988). In this study it ranges from 23 to 35 ft thick and occurs in CHO09 (294 to $329 \mathrm{ft}$ BGS), CH11A (67.2 to $98.7 \mathrm{ft}$ BGS), and CH012 (438.5 to 461.7 ft BGS). It is described in this study as a maroon, calcareous shale, thin to massive bedded, interbedded with a shaley limestone, and micritic to fine-grained.

The gamma ray trace for Unit F correlates extremely well among each of the above coreholes and very well with the composite $\log$ in $L e e$ and Ketelle (1988). It is characterized by two strong peaks of 50 cps or greater in the upper and lower portions of the unit and a single peak of about 45 cps between the two major peaks.

Unit $F$ is a pcorly to moderately fractured interval; fractures per foot range from none th six, and most commonly less than three. The most common type of fracture in this unit in all three coreholes is a bedding plane fracture (dips of $18^{\circ}$ to $40^{\circ}$ south). The fractures in CH11A are primarily slightly open to open, and the fractures in the deeper occurrences of this unit are mostly tight. No evidence of calcite growth was noted. The VDLs for the three coreholes show a pattern of thin intervals of fractures interlayered with thin intervals of unfractured material. The BHTV logs show the lightly fractured nature of this unit, with a slight increase in fracture density at the base of the unit. Upward flow was recorded throughout this unit, based on the flowmeter data for CHOO9, with good correlation among changes in flow rates and open fractures identified on the BHTV, VDL, and geologist's logs.

Tables A3.1, A4.1, and A5.1 summarize the other evidence for fracturing and for determining the active fractures; Fig. 3 shows the distribution of the fractured intervals.

\subsubsection{Unit G}

Portirn: of Unit G were encountered in three coreholes, ranging in thickness from 60 to approxinateiy $289 \mathrm{ft}$. In CH11 A it occurs from 7 to $67.2 \mathrm{f} \mathrm{BGS,} \mathrm{in} \mathrm{CHO09} \mathrm{from} 12$ to $294 \mathrm{ft}$ BGS, and in CH012 from approximately 150 to $438.5 \mathrm{ft}$ BGS. Lee and Ketelle (1988) identified $319 \mathrm{ft}$ 
of this variable unit, which they subdivided into three different lithologies. The lower $116 \mathrm{ft}$ consists of a fine- to medium-grained, fossiliferous nodular limestone; the middle 68-ft-thick lithology consists of fine-grained, dense calcarenite, which is less fossiliferous than the lithology below. The upper 135 it are thinly interbedded siltstone and limestone grading upward to nodular and ribbon limestone. These general lithologies are mirrored in CHO12 (the corehole with the most complete section of Unit G), except that the thicknesses are approximately 110,60 , and $120 \mathrm{ft}$ for the lower, middle, and upper lithologies, respectively.

The composite gamma ray trace on Plate 1 of Lee and Ketelle (1988) and the gamma ray logs from CHOO9, CH11A, and CHO12 strongly correlate, in that each of the three lithologies can be clearly identified on each $\log$ and between logs. The characteristic pattern consists of a lower interval with gamma counts averaging 10 to 25 cps, followed by the intermediate lithology with gamma counts averaging 5 to $10 \mathrm{cps}$, and the upper lithology with counts of 15 to $30 \mathrm{cps}$. All three lithologies are represented is CH012, the lower two and most of the upper are identified in CH009, and only the lower portion of the lower lithology is found in CH11A.

Unit $\mathbf{G}$ is one of the more fractured units in this study, with the number of fractures related to the three different lithologies. The highest number of fractures occurs in the upper lithology; in CHOO9, the range is from zero to eight fractures per foot. These fractures are generally bedding plane (dips of $16^{\circ}$ to $45^{\circ}$ south) ranging from slightly open to tight, although a few low-angle and high-angle fractures were woted. The middle lithology of Unit $\mathbf{G}$ averages two to three fractures per foot, and the lower lithology has up to five. The fractures of the middle lithology are essentially all bedding plane (dips of $18^{\circ}$ to $40^{\circ}$ south), slightly open to tight, and the fractures in the lower lithology are mostly bedding plane (dips of $10^{\circ}$ to $60^{\circ}$ south), slightly open to tight, with a few high- and lowangle fractures. The only evidence of calcite mineralization was noted in CH11A.

The VDLs also clearly show the differences in the fractured nature of the three different lithologies, as each lithology can be identified on the VDL based on the nature of the fractures. The upper unit (150 to $268 \mathrm{ft}$ in $\mathrm{CHO} 2$ and 0 to $109 \mathrm{ft}$ in CH009) shows a fracture pattern of distinct sequences of unfractured rock interbedded with fractured intervals. The middle unit (268 to $329 \mathrm{ft}$ in CHO12 and 109 to $179 \mathrm{ft}$ in CHOO9) as a wholc appears to be more massive, with fewer, thinner fractured intervals; this corresponds to the fracture-per-foot $\log$ for that interval. The lower unit is fractured more than the middie and less than the upper unit, and the sequences of unfractured rock are slightly less distinct.

Flowmeter logs for $\mathrm{CHOO9}$ and $\mathrm{CHO12}$ show that the majority of the active flow zone intervals occur in Unit G. About $80 \%$ of the depths with fluid entry points correspond to fractured intervals in the BHTV, VDL, and geologist's logs.

Tables A3.1, A4.1, and A5.1 summarize the other evidence for fracturing and for determining the active fractures, and Fig. 3 shows the distribution of the fractured intervals. Most of the Unit $\mathrm{G}$ fractures occur in $\mathrm{CHOO9}$ and C.H012. Fractures participating in groundwater flow are frequent and occur most often in $\mathrm{CHOO9}$. 


\subsubsection{Unit H}

Lee and Ketelle's study (1988) only penetrated the lower $28 \mathrm{ft}$ of Unit H, which was characterized by interbedded calcareous siltstone and fine-grained limestone. In this study Unit $H$ is the uppermost unit encountered in CH012, with a gradational contact to Unit G at approximately $150 \mathrm{ft}$. In CH012 the unit is characterized by finely interbeded limestone and siltstone, with some bioturbation.

The gamma ray trace correlates well with the lower $28 \mathrm{ft}$ of the section available on Plate 1 from Lee and Ketelle (1988). The gamma ray count averages $25 \mathrm{cpm}$ for this unit, with peaks up to 35 cpm.

Unit $\mathbf{H}$ is moderately fractured, with fracture incidence ranging from zero to five fractures per $\mathrm{ft}$. The greatest number of fractures per foot occur in the upper $70 \mathrm{ft}$ of the unit. Bedding plane fractures are the most common (dips of $22^{\circ}$ to $40^{\circ}$ ), ranging about equally from tight to open; calcite filling is also common. Other fractures encountered in this unit include high-and low-angle fractures and one dip-normal, dip-parallel set. The VDL shows the more fractured nature of the upper unit and may show the transition to Unit $G$ at about 150 to $154 \mathrm{ft}$. The BHTV log is of poor quality but does suggest more fractured intervals in the upper portion of the unit. Flowmeter data show upward flow between 31 and $150 \mathrm{ft}$ (ranging from 0.078 to $0.099 \mathrm{gpm}$ ); correlation is good amnng the flowmeter depth intervals measuring changes in flow and the BHTV, VDL, and geologist's logs.

Table A5.1 summarizes the other evidence for fracturing and for determining the active fractures, and Fig. 3 shows the distribution of the fractured intervals.

\subsection{ACTIVE FLOW ZONES}

Coreholes CHOOS and CH012. Flowmeter data available for CHOO9 and CHO12 were used in conjunction with the temperature and differential temperature logs to identify the activ: flow zones in these coreholes. The flowmeter results are presented in Moore and Young (1991); some of the results are discussed here to complement the results of the geophysical surveys. Discrete points of entry and exit could be identified from the flowmeter logs. The temperature and differential temperature logs for coreholes without flowmeter data were used to identify active flow zones. It was not possible to distinguigh between entry and exit points without a flowmeter $\log$ for these coreholes.

One flowmeter survey was nun in CH012 from a depth of 20 to $330 \mathrm{ft}$. A plot of the data is found on Fig. A5.1. Negligible flow was recorded from 330 to $315 \mathrm{ft}$ BGS. At $310 \mathrm{ft}$, a fluid entry point occurs, and a second, stronger fluid entry point occurs between 302 and $304 \mathrm{ft}$. This fluid entry point is also reflected on the temperature log, which shows a shift to the left (indicative of gaining flow) and on the differential temperature log. Moving up the borehole, a gradual increase in flow is recorded to a depth of about $200 \mathrm{ft}$. This is reflected on the temperature log as a relatively straight trace.

An exiting zone gradually begins between 180 and $200 \mathrm{ft}$ BGS and is reflected on the temperature $\log$ by a gradual shift to the right (indicative of losing flow). The fluid loss becomes greater between 
180 and $160 \mathrm{ft}$, when the flow rate drops from 0.114 to $0.099 \mathrm{gpm}$. A general loss of water continues until a depth of $30 \mathrm{f}$. This upward losing $20 n e$ is also reflected on the temperature $\log$ by a gradual shift to the right. Berween 30 and $31 \mathrm{ft}$, a major exit of fluid occurs (flow is $0.078 \mathrm{gpm}$ at $31 \mathrm{ft}$ and $0.003 \mathrm{gpm}$ at $30 \mathrm{ft}$ ). The temperature $\log$ also reflects this exit by the sharp shift to the right (indicative of losing flow) beginning at $31 \mathrm{ft}$. Negligible flow exists for the remainder of the borehole.

Portions of Units $\mathbf{G}$ and $\mathbf{H}$ were within the interval over which flow was logged. In general, the logged portion of Unit $G$ was an upward gaining zone, and the portion of Unit $H$ that was logged was an upward losing zone. The exit zone, especially between 180 and $160 \mathrm{ft}$, corresponds roughly to the gradational contact between these two units.

Two flowmeter logs were aun on CHOO9 due to operational problems: between 20 and $340 \mathrm{ft}$ (on October 16, 1991) and 140 and $345 \mathrm{ft}$ (on November 5, 1991). A plot of both flowmeter logs is shown on Fig. A3.1.

For the October $\log$, the first discrete entry point is between 320 and $340 \mathrm{ft}$ BGS, when the flow increases from 0.008 to $0.159 \mathrm{gpm}$. A zone of positive upward flow persists until $180 \mathrm{ft}$, when an exit point occurs between 180 and $170 \mathrm{ft}$. Fluid entry begins again between 170 and $160 \mathrm{ft}$, although slightly less than the deeper flow zone, and continues until a discrete eait point between 134 and 135 ft (flow drops from 0.118 to $0.007 \mathrm{gpm}$ ). This exit point is obvious on the temperature $\log _{\text {, as }}$ reflected by a sharp shift to a higher temperature, and on the differential temperature log, which shows a prominent peak. The remainder of the borehole has essentially negligible flow.

For the November log, fluid entry first occurs between 339 and $338 \mathrm{ft}$ BGS. Upward flow continues to occur until between 223 and $221 \mathrm{ft}$, when the flow drops from 0.087 to $0.035 \mathrm{gpm}$. A second entry point occurs between 220 and $190 \mathrm{ft}$, with a gradual exit beginning betweer. 170 and $150 \mathrm{ft}$.

Portions of Units E, F, and G are included in the two flowmeter logs for CH009. The lowermost point of fluid entry occurs at or near the upper contact of Unit $E$, and Unit $F$ is entirely within a zone of upward flow. Unit $G$ has discrete points of both fluid entry and exit.

Other coreholes. Because flowmeter data were not available for the remaining coreholes (due to hole conditions, denied access, and schedule constraints), differentiation between fluid entry and exit points is not possible. However, the temperature and differential temperature logs and, in some cases, the caliper logs, may be used to identify some of the areas with more obvious fluid entry or exit points.

An active fracture occurs in $\mathrm{CHOO6}$ at approximately $325 \mathrm{ft} \mathrm{BGS}$, which coincides with the formation contact between Units A and B. Oher active fractured intervals occur at about 283 to 286 $f t$ and between 220 and $229 \mathrm{ft}$ BGS. Based primarily on the temperature log, a significant entry or exit point occurs between about 150 and $170 \mathrm{ft} \mathbf{~ B G S}$. From 70 to about $150 \mathrm{ft}$, an overall fractured interval is encountered, based on the steps en the temperature $\log$ and the peaks on the differential temperature log. 
Fluid entry or exit points are obvious on the caliper, temperature, differential temperature, and BHTV logs for CH07A. Intervals on the caliper $\log$ indicative of fractures, which are also visually obvious on the BHTV, at about 49-51, 66-67, 72-73, 89-90, and 162-163 $\mathrm{ft}$ BGS. Shifts in the temperature and differential temperature logs are also noted at these intervals, with the most dramatic shifts occurring at 49-51 and 89-90 ft.

Three active flow zones apparent on the temperature and differential temperature logs for CH1 iA occur at approximately 85, 105, and $180 \mathrm{ft}$ BGS. The sharp shift to the left on the temperature $\log$ may be a reflection of a "dead" hole, where the fluid is cooling to ambient conditions.

The lowermost entry or exit point in FT10 is a depth of approximately $348-350 \mathrm{ft}$ BGS. Other points of entry or exit uccur at about 276, 203, 159, and $\$ 3 \mathrm{ft}$ BGS. A major point of fluid movement occurs at approximately 45-50 ft BGS.

\subsection{SUMMARY OF OBSERVATIONS}

The objective of identifying fractured bedrock zones and active fractures within those zones was accomplished for all coreholes to varying degrees, depending on types of data available. Geologist's logs, BHTV surveys, acoustic logs (VDL and velocity), electric logs (SPR and SP), and caliper logs all provide information on the presence and orientation of fractures and fracture zones. These logs do not provide objective information as to whether the fractures are open, healed, or partly healed, although subjective interpretations of fracture character can sometimes be made.

Temperature logs, both gradient and differential, proved to be the most sensitive indicators of fractures with associated groundwater circulation. Temperature gradient shifts associated with flow below the threshold detection limit of the flowmeter tool can be detected.

As noted previously, a temperature gradient shift at a depth coinciding with fracture identified on geologist's, BHTV, acoustic, electric, or caliper logs was interpreted as a positive indication of an open fracture. Temperature logs do not provide definitive data on either the rite or direction (up or down) of groundwater flow in th: borehole, although subjective interpretations or infirences can sometimes be made. A flowmeter $\log$ is required to make accurate, quantitative mearurements of interborehole flow and to determine the vertical flow direction.

Both active and inactive fractures occur in all coreholes, with some differences between coreholes and with depth. In general, it appears that both types of fractures are more common in the upper $200 \mathrm{ft}$ of stratum penetrated. Coreholes CHO06, CH07A (only completed to $185 \mathrm{ft}$ ), CH009, and CH11A seem to have the greatest number of active fractures in the upper $200 \mathrm{ft}$. However, more data are avaiiable for the upper $200 \mathrm{ft}$ because not all coreholes were drilled to depths of 400 or more $\mathrm{ft}$. For those deeper coreholes (Fig. 3) it appears that fractures are less frequent and active fractures occur less often with depth (c spt for FT10, which has an approximately even distribution with depth).

In all coreholes, the most common type of fracture is bedding plane, although there is an unusual number of dip-normal and dip-parallel fracture sets in the upper $150 \mathrm{ft}$ of CH006. 
CH012 and FT10 have the greatest number of fractures with depth. This reflects the stratigraphic position of Units B and $\mathbf{G}$ within these coreholes, as these units are two of the more fractured units encountered in this study. In contrast, $\mathrm{CH} 1 \mathrm{lA}$ shows a marked decrease in number of fractures and active fractures with depth. Fractured intervals were discussed relative to the regional stratigraphy described by Lee and Ketelle (1988).

Fracture occurrence seems to be controlled by lithology in that fractures are more common in the carbonate or shaley carbonate sequences. The relative abundance of fractures in the upper $200 \mathrm{ft}$ may also be controlled by weathering, due to preferential enlargement of bedding planes from weathering.

Data from available flowmeter logs provided additional insight to the bedrock aquifer flow system. Flowmeter logs available for CHOO9 and CHO12 include only portions of Units E, F, G, and H because schedule constraints only provided for logging the zones where flow was anticipated. These logs show that the majority of the active flow zone intervals occur in Unit G, which is an upward gaining zone. Unit $G$ also has discrete points of both fluid entry and exit. Unit $F$ is entirely within a zone of upward flow, and the portion of Unit $H$ that was logged is an upward losing zone. Fluid entry and exit points correspond to formational contacts between Units E and F in CHOO9, and between Units $\mathbf{G}$ and $\mathbf{H}$ in CH012. Fluid entry and exit points can te identified but not distinguished in the coreholes without flowmeter logs. 


\section{REFERENCES AND BIBLIOGRAPHY}

Asquith, E. B. and C. R. Gibson 1982. "Basic Well Log Evaluation for Geologists," American Association of Petroleum Geologists Methods in Exploration Series.

Bechtel Team, Project Procadure 1250, "Equipment Decon:amination and Release for Unrestricted Use."

Bechtel Team, Project Procedure 1648, "Borehole Logging."

Bechtel Team, Project Procedure 1240.9, "Radiation Source Coniro'."

Environmental Protection Agency 1987. A Compendium of Superfund Field Operations Methods, EPA/540/P-87/001 (OSWER Directive 9355.0-14), pp. 8.4-35 to 3.4-59.

Keys, W. S. 1990. Techriques of Waser Resources Investigations of the United Stared Geological Survey, Book 2, Chapter 2, "Borehole Geophysics Applied to Groundwater Investigations."

Lee, R. R. and R. H. Ketelle 1988. Subsurface Geology of the Chickamauga Group at Oak Ridge National Laboratory. ORNLTM-1074, Oak Ridge National Laboratory.

Moore, G. K. and S. C. Young 1991. Idensification of Groundwater-Proiucing Fractures by Using an Electromagnetic Borehole Flowmeter in Moniroring Wells on the Oak Ridge Reservation, Oak Ridge, Tennessee, ORNL/ER-91, Oak Ridge National Laboratory.

Stockdale, P. B. 1951 Geologic Conditions at the Oak Ridge National Laboratory (X-10) Area Relevant to the Disposal of Radioactive Waste, ORO-58, Department of Energy, Oak Ridge, Tennessee.

WELENCO Inc. Water Well Geophysical Logs, 3rd Edition, 59 p. 
ATTACHMENT 1

CHOOS-GEOPHYSICAL AND GEOLOGIC DATA

2:InMTM-12 
Table A1.1. Summary of fractures identified in corchole CHOW

\begin{tabular}{|c|c|c|c|c|c|c|c|c|c|c|}
\hline $\begin{array}{l}\text { Depth BGS } \\
\text { (n) }\end{array}$ & $\begin{array}{c}\text { Goologic } \\
\text { unit }\end{array}$ & $\begin{array}{l}\text { Fracturea } \\
\text { per } \pi^{\circ}\end{array}$ & BHTV & VDL & Caliper & Temperature & $\begin{array}{c}\text { Delat } \\
\text { tempernture }\end{array}$ & $\begin{array}{c}\text { Devintion } \\
\text { uurvey }\end{array}$ & $\mathbf{S P}$ & Comments \\
\hline $31.1-32.1$ & C & 5 & & & & & & & & $\begin{array}{l}26^{\circ} \text {, BP, open; fracture } \perp \text { to bodding: } \\
\text { plane, open; } 15^{\circ} \text {, fracture eurfaces, o|sen }\end{array}$ \\
\hline $32.1-33.1$ & & 2 & & & & & & & $\mathbf{x}$ & $30^{\circ}$, BP, open \\
\hline 37.9-38.9 & & 2 & & & & & & & & $\begin{array}{l}0^{\circ} \text {, fneture surfice, open: } \perp \text { to } \\
\text { bodding, fracture surface, open }\end{array}$ \\
\hline $4.8-45.8$ & B & 3 & & & & & & & & $5-10^{\circ}$, fracture surface, open \\
\hline $45.8-46.8$ & & 2 & & $m$ & & & & & & Practure surface, open; $35^{\circ}$, BP, open \\
\hline so-s1 & & & & $\mathbf{x}$ & & & $\mathbf{x}$ & & & \\
\hline $51-52$ & & & & $\mathbf{x}$ & $*$ & & & & & \\
\hline $54-55$ & & & & $\mathbf{x}$ & & & & & & \\
\hline $57-58$ & & & & $\mathbf{x}$ & & $\mathbf{x}$ & & & & \\
\hline $59-60$ & & & & $\mathbf{x}$ & & & $\mathbf{x}$ & & & \\
\hline $61.8-62.8$ & & 3 & & & & $\mathbf{x}$ & $\mathbf{x}$ & ..* & & 30-35', BP, sl. open \\
\hline $82.8-63.8$ & & 2 & & $\mathbf{x}$ & & $\mathbf{x}$ & & & & $30-35^{\circ}$, BP, open \\
\hline $67.8-68.8$ & & 3 & $* *$ & $\mathbf{x}$ & & $\mathbf{x}$ & $\mathbf{x}$ & & & $\begin{array}{l}31^{\circ} \text {. BP, al. open; dip-nomal, dip- } \\
\text { parallel fracture at, } 30^{\circ} \text { and } \perp \text { to } \\
\text { bosding, partially healed to sl. open }\end{array}$ \\
\hline $70.8-71.8$ & & 3 & & $\mathbf{x}$ & & & & & $\mathbf{x}$ & $\begin{array}{l}\text { Dip-normal, dip-parallel fracture set; } \\
\text { open }\end{array}$ \\
\hline $71.8-72.8$ & & 2 & & & & & & & & $\perp$ fracture \\
\hline 72.73 & & & ? & & & & $\mathbf{x}$ & & & \\
\hline $73.5-74.5$ & & & $?$ & $\mathbf{x}$ & & B & $\mathbf{x}$ & & & \\
\hline $74.8-75.8$ & & & & & & $\mathbf{x}$ & & & & $20-25^{\circ}$, fracture surface, open \\
\hline$n \cdot 78$ & & & ? & & & $\mathbf{x}$ & $\mathbf{x}$ & & & \\
\hline 78.79 & & & $?$ & $\mathbf{x}$ & & $\mathbf{x}$ & $\mathbf{x}$ & & & \\
\hline 81.82 & & & $\mathbf{x}$ & & & & & & & \\
\hline 82-83 & & & $\mathbf{x}$ & & $\mathbf{x}$ & $\mathbf{x}$ & & & & \\
\hline $83.8-84.8$ & & 3 & $\mathbf{x}$ & $\mathbf{x}$ & $\mathbf{x}$ & & $\mathbf{x}$ & & & $\begin{array}{l}\text { Dip-normal, dip-parallel fracture set, } 32^{\circ} \\
\text { and } \perp \text { to bedding; } 25^{\circ}, \text { BP, open }\end{array}$ \\
\hline $84.8-85.8$ & & 2 & & $\mathbf{x}$ & & & $\mathbf{x}$ & & & $\begin{array}{l}\text { Dip-normal, dip-parallel fracture set, } 25^{\circ} \\
\text { and } \perp \text { to bodding, open }\end{array}$ \\
\hline $85.8 \cdot 86.8$ & & 2 & $\mathbf{x}$ & & & & & & & $\begin{array}{l}\text { Dip-nurmal, dip.parallel fraclure set, } 30^{\circ} \\
\text { and } \perp \text { to hedding. open }\end{array}$ \\
\hline
\end{tabular}


Table A1.1 (continued)

\begin{tabular}{|c|c|c|c|c|c|c|c|c|c|c|}
\hline $\begin{array}{l}\text { Depth BGS } \\
\text { (n) }\end{array}$ & $\begin{array}{c}\text { Goologix } \\
\text { unit }\end{array}$ & $\begin{array}{l}\text { Frectures } \\
\text { per } \mathbb{n}^{t}\end{array}$ & BHTV & VDL & Coliper & Temperalure & $\begin{array}{c}\text { Dele } \\
\text { tempenture }\end{array}$ & $\begin{array}{l}\text { Devintion } \\
\text { survey }\end{array}$ & SP & Commenter \\
\hline $86.8-87.8$ & & 3 & & & & & $\mathrm{x}$ & & & $\begin{array}{l}\text { Dip-normal, dip-parnllel lamure se, } 20^{\circ} \\
\text { and } \perp \text { to bedding, open; } 15^{\circ} \text {, fracture } \\
\text { surface, open }\end{array}$ \\
\hline 87.8-88.8 & & 2 & & & & & & & & Prncture aurface, $\perp$ to bedding, tiem \\
\hline $88.8-89.8$ & & 4 & $\mathbf{x}$ & $\mathbf{x}$ & & & $\mathbf{x}$ & & & $\begin{array}{l}\text { Dip-normal, dip-parallel fracture uet, } 30^{\circ} \\
\text { and } \perp \text { to hedding, al. open, } 30^{\circ}, B \mathrm{~B} \text {, } \\
\text { open }\end{array}$ \\
\hline $89.8-90.8$ & & $\mathbf{s}$ & $\mathbf{x}$ & & & & $x$ & & & $\begin{array}{l}\text { Dip-normal, dip-parallel fracture oed, } 30^{\circ} \\
\text { and } \perp \text { to bedding, open, } 30^{\circ} \text {. BP, open }\end{array}$ \\
\hline $92.8-93.8$ & & 3 & $\mathrm{x}$ & $\mathbf{x}$ & & $\mathbf{x}$ & $\mathbf{x}$ & & & $\begin{array}{l}\text { Dip-nonnal, dip-parallel fracture se, } 31^{\circ} \\
\text { and } \perp \text { to hedding, al. open to light }\end{array}$ \\
\hline $93.8-94.8$ & & 2 & $\mathbf{x}$ & $\mathbf{x}$ & $\mathrm{x}$ & & $\mathbf{x}$ & & & $\begin{array}{l}\perp \text { to bodding. fracture gurface, open: } \\
40^{\circ} \text {, BP, open }\end{array}$ \\
\hline $98.8-99.8$ & & 2 & $\mathbf{x}$ & $\mathbf{x}$ & & & $\mathbf{x}$ & $\mathbf{x}$ & & $\begin{array}{l}\text { Dip-nommal, dip-parallel fracture set, } \\
\text { open to sl. open }\end{array}$ \\
\hline $101.5-102.5$ & & 2 & $\mathbf{x}$ & $\mathbf{x}$ & $\mathbf{x}$ & B & $\mathbf{x}$ & $\mathbf{x}$ & & $\begin{array}{l}15^{\circ} \text {, fncture surface, tight; } \perp \text { to } \\
\text { hodding; sl. open }\end{array}$ \\
\hline $1035-104.5$ & & 2 & $?$ & $\mathbf{x}$ & & & & & & 35', BP, open \\
\hline $10.5-105.5$ & & 4 & & $\mathbf{x}$ & & & & & & $\begin{array}{l}\text { 12-33०, BP, tight to open; dip-nomal, } \\
\text { dip-parallel fracture set, open }\end{array}$ \\
\hline $105.5-106.5$ & & 3 & $\mathbf{x}$ & $x$ & & $\mathbf{x}$ & $x$ & & & $30^{\circ}$. BP, tight and open \\
\hline $106.5-107.5$ & & 3 & $\mathbf{x}$ & & & $\mathbf{x}$ & $\mathbf{x}$ & & & $\begin{array}{l}\text { Dip-normal, dip-parallel tracture set, } \\
\text { open, heavy calcite mineralizetion on cip } \\
\text { fracture }\end{array}$ \\
\hline 107.5-108.5 & & 2 & & $\mathbf{x}$ & & $\mathbf{x}$ & $\mathbf{x}$ & & & $25-40^{\circ}$, BP. sl. open to open \\
\hline $110.5-111.5$ & & 2 & & & $\mathbf{x}$ & & & $\mathbf{x}$ & & $20-30^{\circ}$. BP, open \\
\hline $111.5-112.5$ & & & $\mathbf{x}$ & $\mathbf{x}$ & $\mathbf{x}$ & & & & & \\
\hline $112.5-113.5$ & & 3 & $\mathbf{x}$ & $\mathbf{x}$ & & & & & & $\begin{array}{l}30^{\circ} \text {. BP, open; Dip-normal, dip-paralh:l } \\
\text { fracture set, open }\end{array}$ \\
\hline$: 14.5-116$ & & & $\mathbf{x}$ & $\mathbf{x}$ & $\mathbf{x}$ & & & & & \\
\hline $116.5-117.5$ & & 3 & $\mathbf{x}$ & & & & & & & $\begin{array}{l}\text { Dip-normal, dip-porallel fracture set. } \\
\text { open }\end{array}$ \\
\hline $121.5-123.5$ & & 2 & $\mathbf{x}$ & & & B & $\mathbf{x}$ & & & $\perp$ to bedding. fracture surfaces \\
\hline $124.5-125.5$ & & 3 & & & & $\mathbf{x}$ & & & & $29-35^{\circ}$, BP, sl. open in open \\
\hline
\end{tabular}


Table A1.1 (continued)

\begin{tabular}{|c|c|c|c|c|c|c|c|c|c|c|}
\hline $\begin{array}{l}\text { Depeh BGS } \\
\text { (A) }\end{array}$ & $\begin{array}{l}\text { Gootogic } \\
\text { unit }\end{array}$ & $\begin{array}{c}\text { Fractures } \\
\text { per } \pi^{*}\end{array}$ & BHTV & VDL & Caliper & Temperalure & $\begin{array}{c}\text { Deks } \\
\text { temperature }\end{array}$ & $\begin{array}{l}\text { Deviztion } \\
\text { survey }\end{array}$ & SP & Commenter \\
\hline $125.5-126.5$ & & 7 & $\mathbf{x}$ & $\mathbf{x}$ & & & $\mathbf{x}$ & & & $\begin{array}{l}\text { Dip-normal, dip-paraltel fracture set, } \\
\text { open; low-angle fracture surface, open. } \\
3^{\circ} \text {, BP, open }\end{array}$ \\
\hline 126.5.127.5 & & 3 & $\mathbf{x}$ & $\mathbf{x}$ & & & & & & $\begin{array}{l}\text { Dip-nomal, dip-parallel fracture set, } \\
\text { open to sl. open; } 48^{\circ} \text {, BP, tight }\end{array}$ \\
\hline 128.5-129.5 & & 2 & & $\mathbf{x}$ & $\mathbf{x}$ & B & $\mathbf{x}$ & & $\mathbf{x}$ & $\begin{array}{l}40^{\circ} \text {, BP, open; bow angle fracture } \\
\text { surfice, open }\end{array}$ \\
\hline $130.1-131.1$ & & 2 & $\mathbf{x}$ & $\mathbf{x}$ & $\mathbf{x}$ & & & & & Low angle fracture surface, open \\
\hline$: 31.1-132.1$ & & $\mathbf{3}$ & $\mathbf{x}$ & $\mathbf{x}$ & & & & & & $25-30^{\circ}$, BP, open; $\perp$ 10 bodding \\
\hline 132.1-133.5 & & 2 & $\mathbf{x}$ & $\mathbf{x}$ & $\mathbf{x}$ & & & & & \\
\hline $134.1-135.1$ & & 2 & $?$ & & & & $\mathbf{x}$ & & & $35-43^{\circ}$, BP, s1. open to open \\
\hline $136.1-137.1$ & & 4 & $\mathbf{x}$ & & & $\mathbf{x}$ & $\mathbf{x}$ & & & $\begin{array}{l}\text { Dip-nomal, dip-parallel fracture set, al. } \\
\text { open to tight; } 31-34^{\circ}, \text { BP, sl. open to } \\
\text { tight }\end{array}$ \\
\hline $137.1-138.1$ & & 2 & & & & & $\mathbf{x}$ & & & $22.25^{\circ}$, BP, sl, open to open \\
\hline $138.1-139.1$ & & 2 & $\mathbf{x}$ & $\mathbf{x}$ & & $\mathbf{x}$ & $\mathbf{x}$ & & & $27-28^{\circ}$, BP, open to tight \\
\hline 139.1-140.5 & & 4 & & $x$ & $\mathbf{x}$ & B & $\mathbf{x}$ & & & $\begin{array}{l}\text { Dip-nomal, dip-parallel frecture set, } \\
\text { open; } 31^{\circ} \text {, BP, sl. open; } \perp \text { to bedding. } \\
\text { sl. open }\end{array}$ \\
\hline $144.1-145.1$ & & 2 & $\mathbf{x}$ & $\mathbf{x}$ & $\mathbf{x}$ & & $\mathbf{x}$ & $\mathbf{x}$ & & $\begin{array}{l}\text { Dip-normal, dip-parallel fracture set, } \\
\text { tight and open }\end{array}$ \\
\hline $145.1-146.5$ & & 5 & $\mathbf{x}$ & $x$ & & & & $\mathbf{x}$ & & $\begin{array}{l}\text { Low angle fracture surfaces, open; } 30 \text { - } \\
32^{\circ} \text {. BP, open to light }\end{array}$ \\
\hline $147.1-48.1$ & & 3 & ? & $\mathbf{x}$ & & B & $\mathbf{x}$ & $\mathbf{x}$ & & $30-35^{\circ}$. BP, open and tight \\
\hline 148.1-149.5 & & 5 & $\mathbf{x}$ & $\mathbf{x}$ & & $\mathbf{x}$ & $x$ & & & $\begin{array}{l}\text { Dip-normal, dip-parallel fracture set, sl. } \\
\text { open to open; } \perp \text { tn hedding: } 30^{\circ} \text {, BP, } \\
\text { open; low angle fracture surface, tight }\end{array}$ \\
\hline $149.5-152$ & & 2 & $\mathbf{x}$ & $\mathbf{x}$ & $\mathbf{x}$ & $\mathbf{x}$ & $\mathbf{x}$ & & $\mathbf{x}$ & $33-36^{\circ}$, BP, sl. open to open \\
\hline $15+1: 5$ & & & $\mathbf{x}$ & $\mathbf{x}$ & & B & & & & \\
\hline $157-158$ & & & $?$ & & $\mathbf{x}$ & $\mathbf{x}$ & $\mathbf{x}$ & & & \\
\hline $158.1-159.1$ & & 2 & & & & $\mathbf{x}$ & $\mathbf{x}$ & & & $\perp$ to bedding. open \\
\hline $160-161$ & & & $?$ & $\mathbf{s}$ & $\mathbf{x}$ & $x$ & $\mathbf{x}$ & $\mathbf{x}$ & & \\
\hline $161.1-162.1$ & & 2 & & & & $\mathrm{x}$ & $\mathbf{x}$ & & & $\begin{array}{l}\text { I to bodding, tight; low engle fracture } \\
\text { surface, tight }\end{array}$ \\
\hline
\end{tabular}


Table A1.1 (continued)

\begin{tabular}{|c|c|c|c|c|c|c|c|c|c|c|}
\hline $\begin{array}{l}\text { Depth BGS } \\
\text { (n) }\end{array}$ & $\begin{array}{l}\text { Goologic } \\
\text { unit }\end{array}$ & $\begin{array}{c}\text { Fractures } \\
\text { per } \mathbb{A}^{*}\end{array}$ & BHTV & VDL & Caliper & Temperature & $\begin{array}{c}\text { Deke } \\
\text { temperature }\end{array}$ & $\begin{array}{c}\text { Devintion } \\
\text { survey }\end{array}$ & $\mathbf{S P}$ & Commonts \\
\hline $162-163$ & & & $x$ & $\mathbf{x}$ & & $\mathrm{x}$ & $x$ & & & \\
\hline 166.1-167.1 & & 3 & $\mathbf{x}$ & $\mathbf{x}$ & & $\mathbf{x}$ & & & & $\begin{array}{l}\perp \text { to bedding, al. open } 30^{\circ} \text {. BP, sl, open } \\
\text { to open }\end{array}$ \\
\hline $167.1 \cdot 168.1$ & & 2 & $x$ & $\mathbf{x}$ & & & & & & $23-24^{\circ}$, BP, sl. open to tighe \\
\hline $168.1-169.1$ & & 2 & & $\mathbf{x}$ & & & $\mathbf{x}$ & & & Low angle fracture, sl. open to open \\
\hline $170.1 \cdot 171.1$ & & 2 & & $\mathbf{x}$ & & B & & & & $\begin{array}{l}\text { Low angle frncture surface, tight; } 35^{\circ} \text {, } \\
\text { BP, ol. open }\end{array}$ \\
\hline $175-176$ & & & & & & & $\mathbf{x}$ & & & \\
\hline $177.1-178.1$ & & 3 & $?$ & $\mathbf{x}$ & $\mathbf{x}$ & & $\mathbf{x}$ & & & $\begin{array}{l}35^{\circ} \text {, BP sl. open; } \perp \text { in hedding, light; } \\
\text { low angle fracture surface. some calcite } \\
\text { mineralization, open }\end{array}$ \\
\hline $178-179.1$ & & & $\mathbf{x}$ & $\mathbf{x}$ & & & $\mathbf{x}$ & & & $\begin{array}{l}\text { Low angle fracture surfaces, wome calcile } \\
\text { mineralization, open: } 41^{\circ} \text {. BP, heavy } \\
\text { calcite minenalization, open }\end{array}$ \\
\hline $179.1-180.1$ & & 2 & $\mathbf{x}$ & $\mathbf{x}$ & & & & $\mathbf{x}$ & & 40-43. BP, open \\
\hline $184.1-185.1$ & & 2 & $\mathbf{x}$ & $\mathbf{x}$ & & & $\mathbf{x}$ & & & 25-30'. BP, open and tight \\
\hline $185.1-186.1$ & & 2 & & & & & & & & $30-40^{\circ}$. BP. open and light \\
\hline $186-187$ & & & & $\mathbf{s}$ & & & & & & \\
\hline $189-190$ & & & & & & & $\mathbf{x}$ & $\mathbf{x}$ & & $\begin{array}{l}40^{\circ} \text {, high angle fracture surface, open; } \\
\text { low angle fracture surface, sl. open; }-L \\
\text { to bedding }\end{array}$ \\
\hline :93.1-194.1 & & 3 & & $\mathbf{x}$ & $\mathbf{x}$ & & & & & \\
\hline $194.1-195.1$ & & 2 & $\mathbf{x}$ & $\mathbf{x}$ & $\mathbf{x}$ & $\mathbf{x}$ & & & & $26-28^{\circ}$, BP, sl. open to open \\
\hline $195.1 \cdot 196.1$ & & 3 & $\mathbf{x}$ & $\mathbf{x}$ & & & & & & Low angle fracture surfaces, open \\
\hline $196.1-197.1$ & & 6 & $\mathbf{x}$ & & & & & & & $30^{\circ}$. BP. open \\
\hline$|97.1-198|$. & & 2 & $\mathbf{x}$ & $\mathbf{x}$ & & & & & $\mathbf{x}$ & $32 \circ$, BP, open \\
\hline $198.1-199.1$ & & 5 & & $\mathrm{x}$ & & & $\mathrm{x}$ & & $\mathbf{x}$ & $\begin{array}{l}\text { Dip-normal, dip-parallel fracture set, } \\
\text { cakcite mineralization, open: } 32 \text {. BP, } \\
\text { open }\end{array}$ \\
\hline $199.1 \cdot 200.1$ & & 3 & $\mathbf{x}$ & $\mathbf{x}$ & & & $x$ & & $\mathbf{x}$ & $\begin{array}{l}25-34^{\circ} \text {, BP; low angle fracture surface. } \\
\text { open }\end{array}$ \\
\hline 202.1203 .1 & & 2 & & $\mathbf{x}$ & & & & & & 31-33', BP, slightly open to tight \\
\hline $203.1-204.5$ & & 2 & $\mathbf{x}$ & $\mathbf{x}$ & & & & & & $31^{\circ}$, BP, sl, open \\
\hline
\end{tabular}


Table A1.1 (continued)

\begin{tabular}{|c|c|c|c|c|c|c|c|c|c|c|}
\hline $\begin{array}{l}\text { Depth BGS } \\
\text { (n) }\end{array}$ & $\begin{array}{c}\text { Genlogic } \\
\text { unit }\end{array}$ & $\begin{array}{c}\text { Frectures } \\
\text { per } \boldsymbol{A}^{s}\end{array}$ & BHTV & VDL & Caliper & Temperature & $\begin{array}{l}\text { Dela } \\
\text { temperalure }\end{array}$ & $\begin{array}{l}\text { Devintion } \\
\text { survey }\end{array}$ & SP & Comments" \\
\hline $210.1-211.5$ & & 3 & $x$ & $\mathbf{x}$ & & & & $\mathbf{x}$ & & $\begin{array}{l}\text { I to bedding, heavy calcine } \\
\text { minenlization, open; } 23-25^{\circ} \text {. BP, open } \\
\text { and tighe }\end{array}$ \\
\hline $212.1-213.1$ & & 2 & & $\mathbf{x}$ & $\mathbf{x}$ & $\mathbf{x}$ & & & & Low angle fracture surface, open \\
\hline $.17 .1-218.1$ & & 2 & & & $\mathbf{x}$ & & & $\mathbf{x}$ & & $\begin{array}{l}\text { Low angle fracture iurfaces, open; } 23 \text { ', } \\
\text { frecture surface, s1. open }\end{array}$ \\
\hline 218-219 & & & & & & B & $\mathbf{x}$ & & & \\
\hline $223.1-224.1$ & & 2 & & $\mathbf{x}$ & & & $\mathbf{x}$ & & & 35॰. BP. open; fracture surface, open \\
\hline $224-225$ & & & $\mathbf{x}$ & & $\mathbf{x}$ & & & & & \\
\hline $226.1-227.1$ & & 2 & & & & & $\mathbf{x}$ & & & $\begin{array}{l}\text { Low engle fracture surface, open; } \perp \text { :0 } \\
\text { bedding, tight }\end{array}$ \\
\hline $227.1-228.1$ & & 4 & $\mathbf{x}$ & & & & $\mathbf{x}$ & & $\mathbf{x}$ & Low angle fracture surfaces, open \\
\hline $228-229$ & & & $\mathbf{x}$ & $\mathbf{x}$ & & & & & & \\
\hline $231.1-232.1$ & & 3 & & & & & & $\mathbf{x}$ & $\mathbf{x}$ & $\begin{array}{l}20^{\circ} \text {, how angle fracture surface, open; } \\
\text { bow angle fracture surface, open; } \perp \text { to } \\
\text { bedding, sl. open }\end{array}$ \\
\hline $232-233$ & & & $\mathbf{x}$ & $\mathbf{x}$ & & & & & & \\
\hline $233.1-234.1$ & & 2 & $\mathbf{x}$ & $\mathbf{x}$ & & $\mathbf{x}$ & & & & $29^{\circ}$, BP, open \\
\hline $234.1-235.1$ & & 4 & & & & & & $\mathbf{x}$ & & Low angle fracture surfaces, open \\
\hline $235.1-236.1$ & & 3 & & & & & & & & Low angke fracture surfaces, open \\
\hline 244.7 .245 .7 & & 2 & & & & & & & & $\begin{array}{l}42^{\circ} \text {, fracture surface, si. open; } 35^{\circ}, \text { B/? } \\
\text { open }\end{array}$ \\
\hline 246-247 & & & $\mathbf{x}$ & $\mathbf{x}$ & & & & & & \\
\hline 247.4248 .4 & & 3 & & $\mathbf{x}$ & & & $\mathbf{x}$ & $\mathbf{x}$ & & 30-38 . BP, open and tight \\
\hline 248.4-249.4 & & 3 & & & $\mathbf{x}$ & $\mathbf{x}$ & & $\mathbf{x}$ & & Low angle fneture surfaces, open \\
\hline $250.4-251.4$ & & 4 & $x$ & $\mathbf{x}$ & $\mathbf{x}$ & $\mathrm{x}$ & $\mathbf{x}$ & $\mathbf{x}$ & & $26-40^{\circ}$, BP, open and tight \\
\hline $251.4-252.4$ & & 2 & $\mathbf{x}$ & $\mathbf{x}$ & & B & & & & $\begin{array}{l}40^{\circ} \text {, BP, if. open; low angle fracture } \\
\text { surface, open }\end{array}$ \\
\hline $252.4-253.4$ & & 2 & $\mathbf{x}$ & $\mathbf{x}$ & $\mathbf{x}$ & & & & & $34-37^{\circ}$, sl. open \\
\hline $253-254$ & & & $\mathbf{x}$ & $\mathbf{x}$ & & & & & & \\
\hline $25+255$ & & & $\mathbf{x}$ & $\mathbf{x}$ & & & & & & \\
\hline $255.2-256.2$ & & 2 & $\mathrm{x}$ & $\mathbf{x}$ & & & & & $x$ & $\begin{array}{l}\text { 40', BP, sl open; low angle fracture } \\
\text { surface, open }\end{array}$ \\
\hline TM⿻o⿰丿⿱丄𠃍: & & & & & & & & & & \\
\hline
\end{tabular}


Table A1.I (continued)

\begin{tabular}{|c|c|c|c|c|c|c|c|c|c|c|}
\hline $\begin{array}{l}\text { Depeh BGS } \\
\text { (A) }\end{array}$ & $\begin{array}{l}\text { Goologic } \\
\text { inis }\end{array}$ & $\begin{array}{c}\text { Fractures } \\
\text { per } \|^{t}\end{array}$ & BHTV & VDL & Caliper & Tempenature & $\begin{array}{c}\text { Detas } \\
\text { tempenture }\end{array}$ & $\begin{array}{c}\text { Devintion } \\
\text { survey }\end{array}$ & SP & Comments \\
\hline $256.2-257.2$ & & 3 & & $\mathbf{X}$ & & & & & & $\begin{array}{l}\text { Low angle fracture surface, sl. open to } \\
\text { tight }\end{array}$ \\
\hline $257.5-158.5$ & & & $\mathbf{x}$ & $\mathbf{x}$ & & & & & & \\
\hline $259-260$ & & & & & $\mathbf{x}$ & & & & & \\
\hline $261-263$ & & & $\mathbf{x}$ & & & & & & & \\
\hline $264.5-265$ & & & $\mathbf{x}$ & $\mathbf{x}$ & & & & $\mathbf{x}$ & & \\
\hline 274 & & & & $\mathbf{x}$ & $\mathbf{x}$ & & & & & \\
\hline $276-277$ & & 3 & & $\mathbf{x}$ & $\mathbf{x}$ & & & & $\mathbf{x}$ & $\begin{array}{l}\text { Low angle fracture surfices, }<20^{\circ} \text {, } \\
\text { open and tight }\end{array}$ \\
\hline 283.5 & & & $\mathbf{x}$ & $\mathbf{x}$ & & B & & & & \\
\hline $291-292$ & & & & & & & $\mathbf{x}$ & & & \\
\hline 294.295 & & 2 & & $\mathbf{x}$ & $\mathbf{x}$ & & & $\mathbf{x}$ & $\mathbf{x}$ & $37^{\circ}$, BP, light; low angle fracture, open \\
\hline $296-297$ & & 2 & $\mathbf{x}$ & $\mathbf{x}$ & $\mathbf{x}$ & & $\mathbf{x}$ & & & 26-32', BP, al, open to open \\
\hline $300-301$ & & 3 & $\mathbf{x}$ & $\mathbf{x}$ & & & & & & $\begin{array}{l}\text { Dip-normal, dip-parallel fracture se, sl. } \\
\text { open to tight; } 32^{\circ} \text {, BP, tight }\end{array}$ \\
\hline $302-303$ & & 4 & $\mathbf{x}$ & $\mathbf{x}$ & & & & & $\mathbf{x}$ & $23-27^{\circ}$. BP, ul, open to tight \\
\hline 303-304 & & & $\mathbf{x}$ & $\mathbf{x}$ & & & & $\mathbf{x}$ & & \\
\hline $313-314.5$ & & 2 & $\mathbf{x}$ & & $\mathbf{x}$ & & & $\mathbf{x}$ & & $\begin{array}{l}25^{\circ} \text {, BP, open; } 45^{\circ} \text {, high angle fraclurs } \\
\text { surface, open }\end{array}$ \\
\hline 315-316 & & & 2 & & & & & & & \\
\hline 316-317 & & & $?$ & & $\mathbf{x}$ & & & & & \\
\hline $317-318$ & & 3 & $\mathbf{x}$ & $\mathbf{x}$ & $\mathbf{x}$ & & & & & $25-28^{\circ}$, BP, sl. open to open \\
\hline 3i8-319 & & 3 & $x$ & $\mathbf{x}$ & & & & & & $25^{\circ}, \mathrm{BP}$, tight \\
\hline $319-320$ & & & & $\mathbf{s}$ & & & & & & \\
\hline 320.321 & & 2 & $\mathbf{x}$ & & & & & $x$ & & Low angle fracture surfaces, sl. open \\
\hline 323-324 & & & & & & & $s$ & & & \\
\hline 326-327 & & 3 & $x$ & $x$ & & B & & $\mathbf{x}$ & $\mathbf{x}$ & $25-30^{\circ}$, BP, open \\
\hline $327-328$ & & & $\mathbf{x}$ & $\mathbf{x}$ & & & & & & \\
\hline 323-329 & & & $\mathbf{x}$ & $\mathbf{x}$ & & & & & & \\
\hline 329-330 & & 2 & $?$ & $\mathbf{x}$ & & & & & $\mathbf{x}$ & 24-31, BP, s1. open to open \\
\hline $330-331$ & & 2 & $\mathbf{x}$ & & & & & & & $\begin{array}{l}28-35^{\circ} \text {, BP, heavy colcite mineralization, } \\
\text { al. open to open }\end{array}$ \\
\hline 336-337 & & & & $\mathbf{x}$ & $\mathbf{x}$ & & & $\mathbf{x}$ & $\mathbf{x}$ & \\
\hline
\end{tabular}


Tabile A1.1 (comtinued)

\begin{tabular}{|c|c|c|c|c|c|c|c|c|c|c|}
\hline $\begin{array}{l}\text { Depth BGS } \\
\text { (n) }\end{array}$ & $\begin{array}{l}\text { Geologic } \\
\text { unit }\end{array}$ & $\begin{array}{c}\text { Frectures } \\
\text { per } \pi\end{array}$ & BHTV & VDL. & Eoliper & iemperzture & $\begin{array}{l}\text { Detre } \\
\text { Komperatus: }\end{array}$ & $\begin{array}{c}\text { Deviaion } \\
\text { nurvey }\end{array}$ & $\mathbf{S P}$ & Comments \\
\hline 338-339 & & & $\mathbf{x}$ & & $\mathbf{y}$ & & & $\mathbf{x}$ & & \\
\hline 347-348 & & & & $\mathbf{x}$ & x & & s & $\mathbf{x}$ & & \\
\hline $357-359$ & & 2 & $\mathbf{x}$ & $x$ & $x$ & $\mathbf{s}$ & & Y & $\mathbf{x}$ & $\begin{array}{l}\text { High angle fracture aurface, sl. open; } \\
34^{\circ} \text {, BP, calcike mineralization, al. open }\end{array}$ \\
\hline $375-377$ & & & & $\mathbf{s}$ & & & & & $x$ & \\
\hline $378-379$ & & 2 & $\mathbf{x}$ & & $\mathbf{x}$ & & & $x$ & & $\begin{array}{l}\text { Dip-normal, dip-parallel fracture sed, dip } \\
30^{\circ} \text {, heavy calcite mineralizstion, tighe }\end{array}$ \\
\hline 383-384 & & & $\mathbf{x}$ & $\mathbf{x}$ & $\mathbf{x}$ & & & & $\mathbf{x}$ & \\
\hline $386-387$ & & & $?$ & & & & $s$ & & $x$ & \\
\hline 387-388 & & & $\mathbf{x}$ & & $\mathbf{x}$ & B & & & & \\
\hline 388-389 & & 2 & $x$ & $x$ & $\mathbf{x}$ & & & & & 32-31 ${ }^{\circ}$, BP, at. open to light \\
\hline 390-391 & & 3 & $\mathbf{x}$ & $Y$ & $\mathbf{x}$ & & & & & $\begin{array}{l}\text { 33-36 , BP. heavy calcite mineralization. } \\
\text { al. open to open }\end{array}$ \\
\hline $391-392$ & & 2 & & & & & & & & $32^{\circ}$, BP, al. open and light \\
\hline 393-394 & & & $?$ & $\mathbf{x}$ & $x$ & & & & & \\
\hline $393-396$ & & 2 & $\mathbf{x}$ & & & & & & & $30^{\circ}$, BP, tight and open \\
\hline $396-937$ & & & $\mathbf{x}$ & $\mathbf{x}$ & & & & & & \\
\hline $397-398$ & & & $\mathbf{x}$ & $\mathbf{x}$ & $\because:$ & & & & & \\
\hline $398-399$ & & $z$ & $\mathbf{x}$ & $\mathbf{x}$ & $\mathbf{x}$ & & & & & $35-40^{\circ}$, BP, al. open in light \\
\hline $399-400$ & & 2 & $\mathbf{x}$ & $\mathbf{x}$ & $\mathbf{x}$ & & & & & $28-32^{\circ}$, tight \\
\hline$+02-103$ & & 3 & +++ & & & & & & & $\begin{array}{l}\text { Dip-normal, dip-parallel fracture set, } \\
\text { tight; } 30^{\circ} \text {, BP, il. open to tight }\end{array}$ \\
\hline
\end{tabular}

Only those depth intervals obtainad from the geologist's bga have an accuracy of $0.1 \mathrm{f}$. Depth intervals from other loga were nok as accurate.

'From geologist's log.

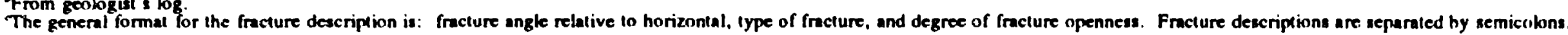
LEGEND

$$
\begin{array}{ll}
\mathbf{X} & =\text { Log response } \\
\mathbf{S} & =\text { Slight lig retponse } \\
? & =\text { Questionable due io log quality } \\
+++ & =\text { Denotes end of log } \\
\text { B } & =\text { Baseline shit in log curve }
\end{array}
$$

1. BP - Bedding plane fracture: a fracture that occurs atong the plane of bedding, which typically ranged from $25-40^{\circ}$ a meanured perpendicular to the kng axis of the core. 2. Dip-nommal tracture - Any fracture that is perpendicular to bedding; typically either parallel. : perpendivislar to atrike.

3. Dip-parallel fracture - Any fracture that is parallel to bodding. 
Table A1.I (contimued)

4. Low angte fracture - As measured perpendicular to the long axis of the core. a bow angle fracture is generally at an anglo leas than bedding

5. High angle fracture - As measured perpendicular to the bons axis of the core. a high angle fracture is encrelly at an angle grealer than bedding. 


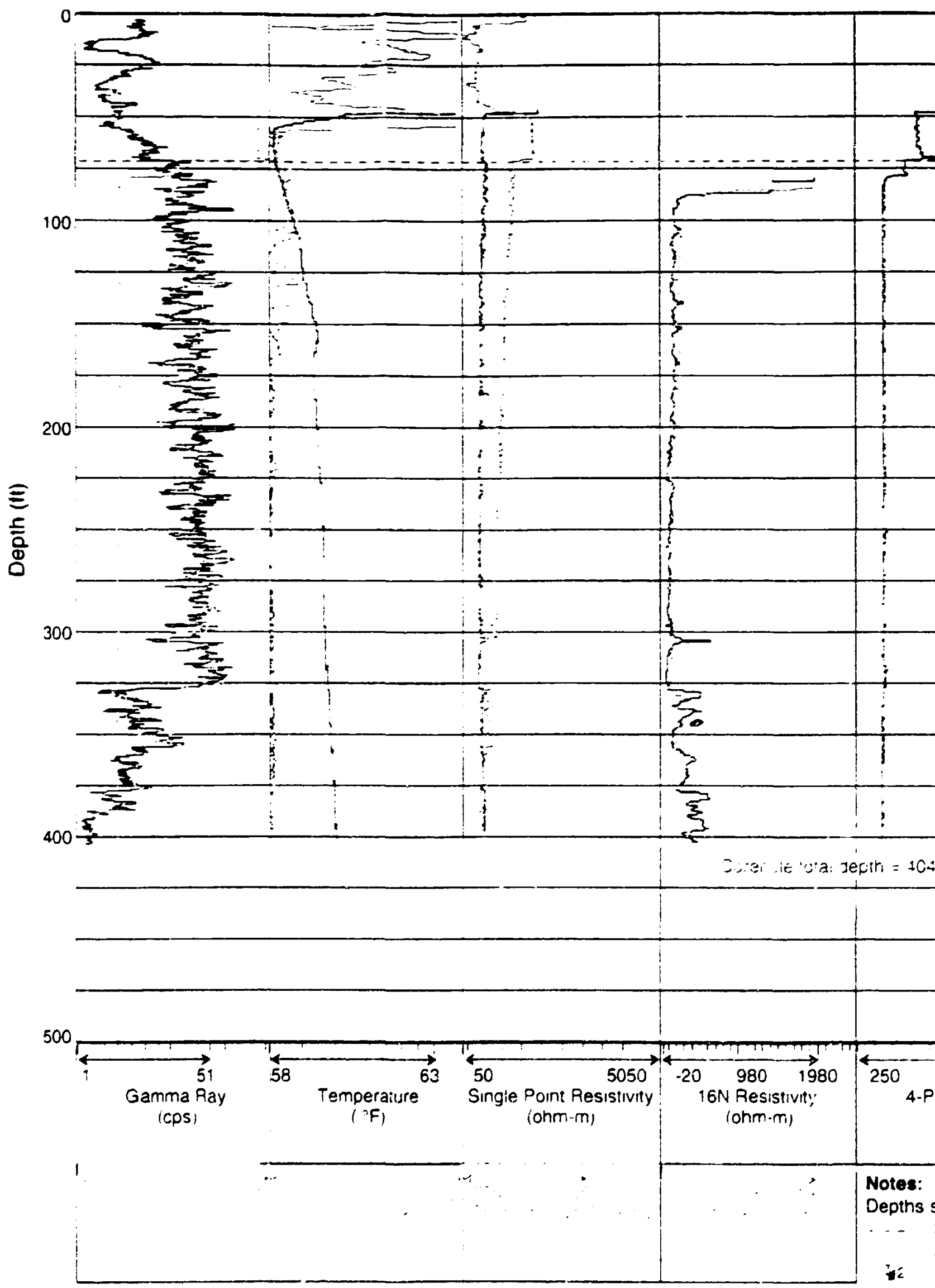




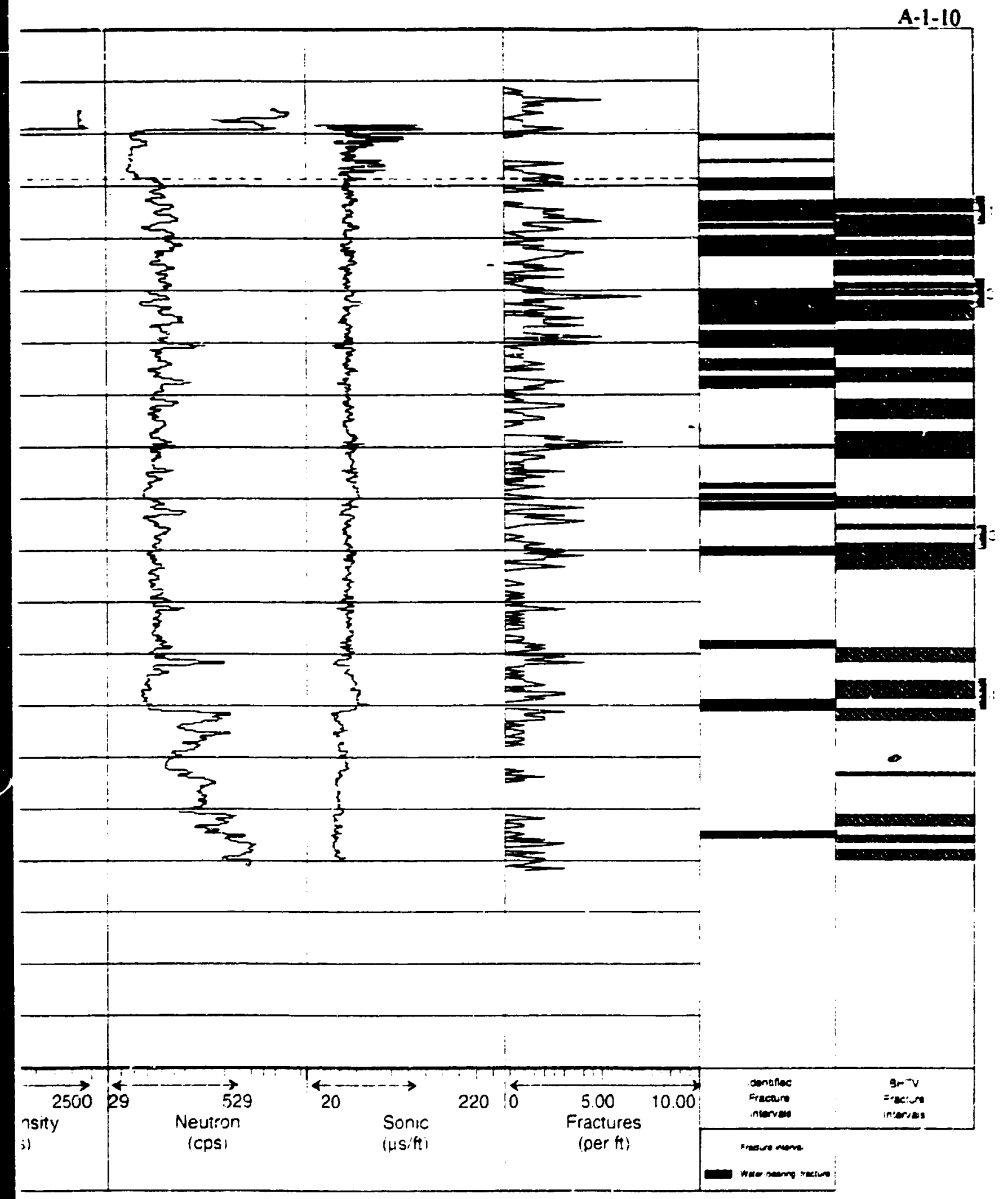

In are from ground surface

ace casing depth $=70.8 \mathrm{H}$

ic water level at time of logging $=47.2 \mathrm{ft}$

ker test interval

Fig. Al.1. CHOO6 borehole geophysical logs. 


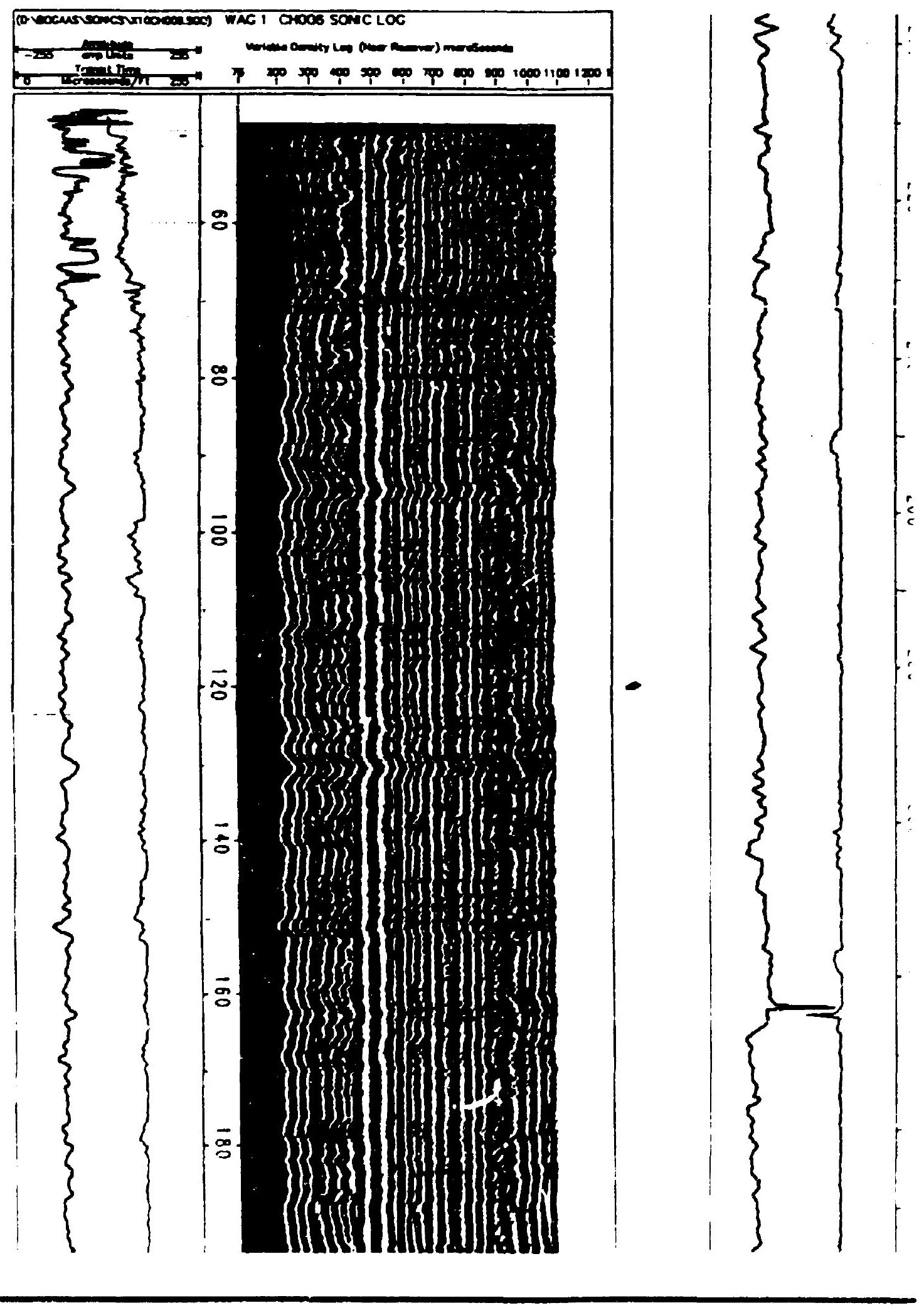



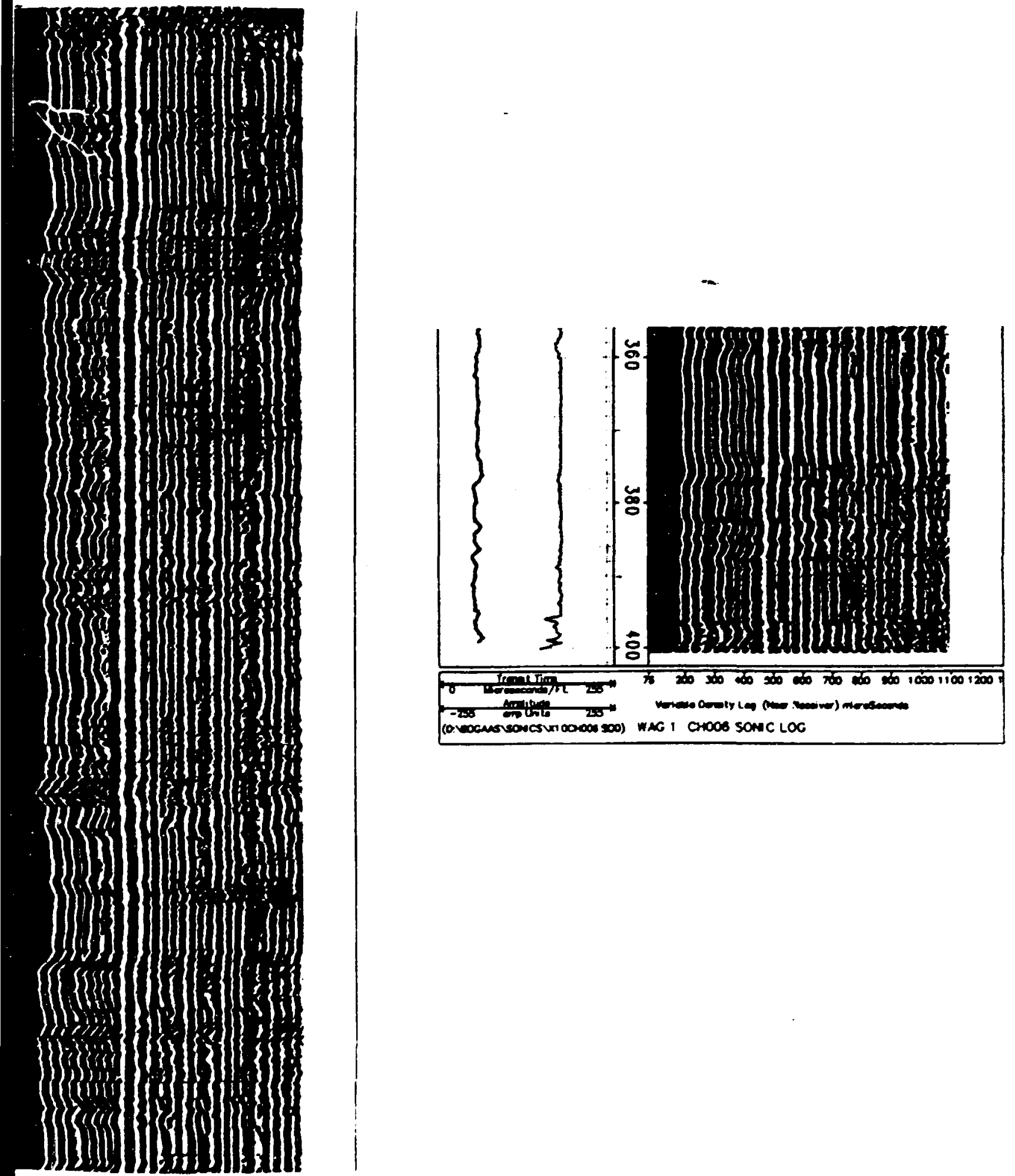

Fig. A1.2. CHOOb variable density (acoustic) hog. 
A-1-12

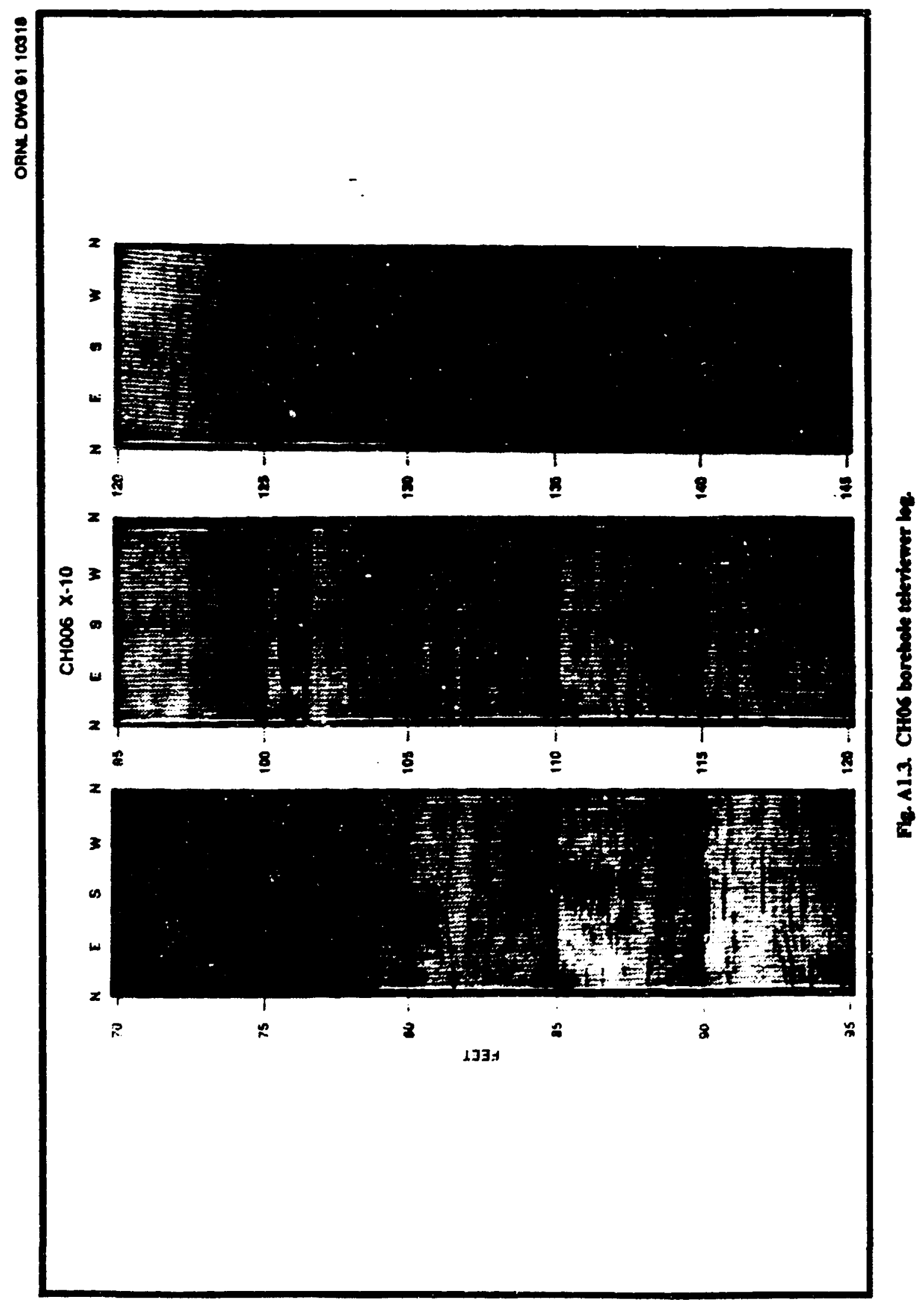




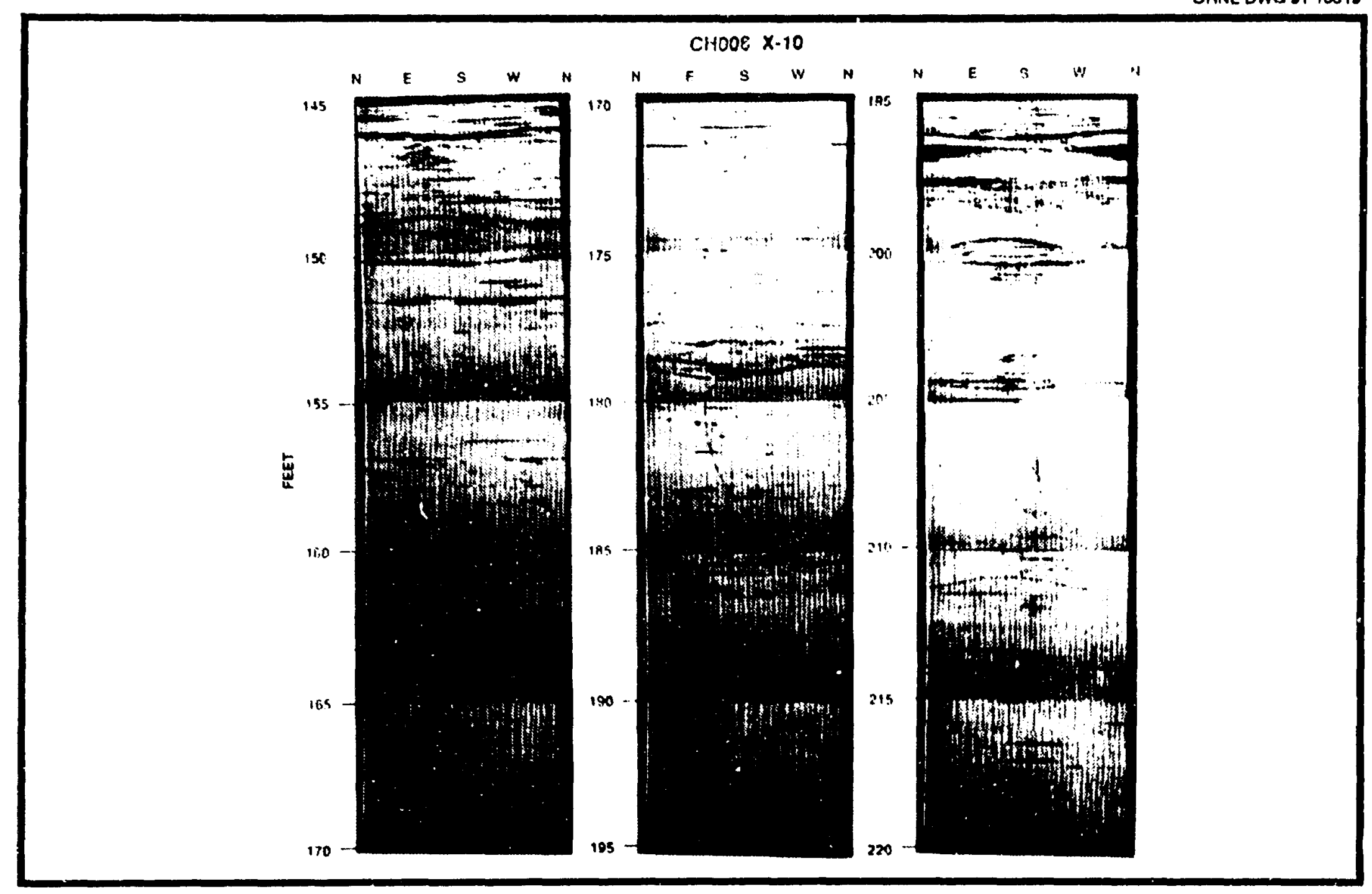

Fi. A1.3. (continued). 


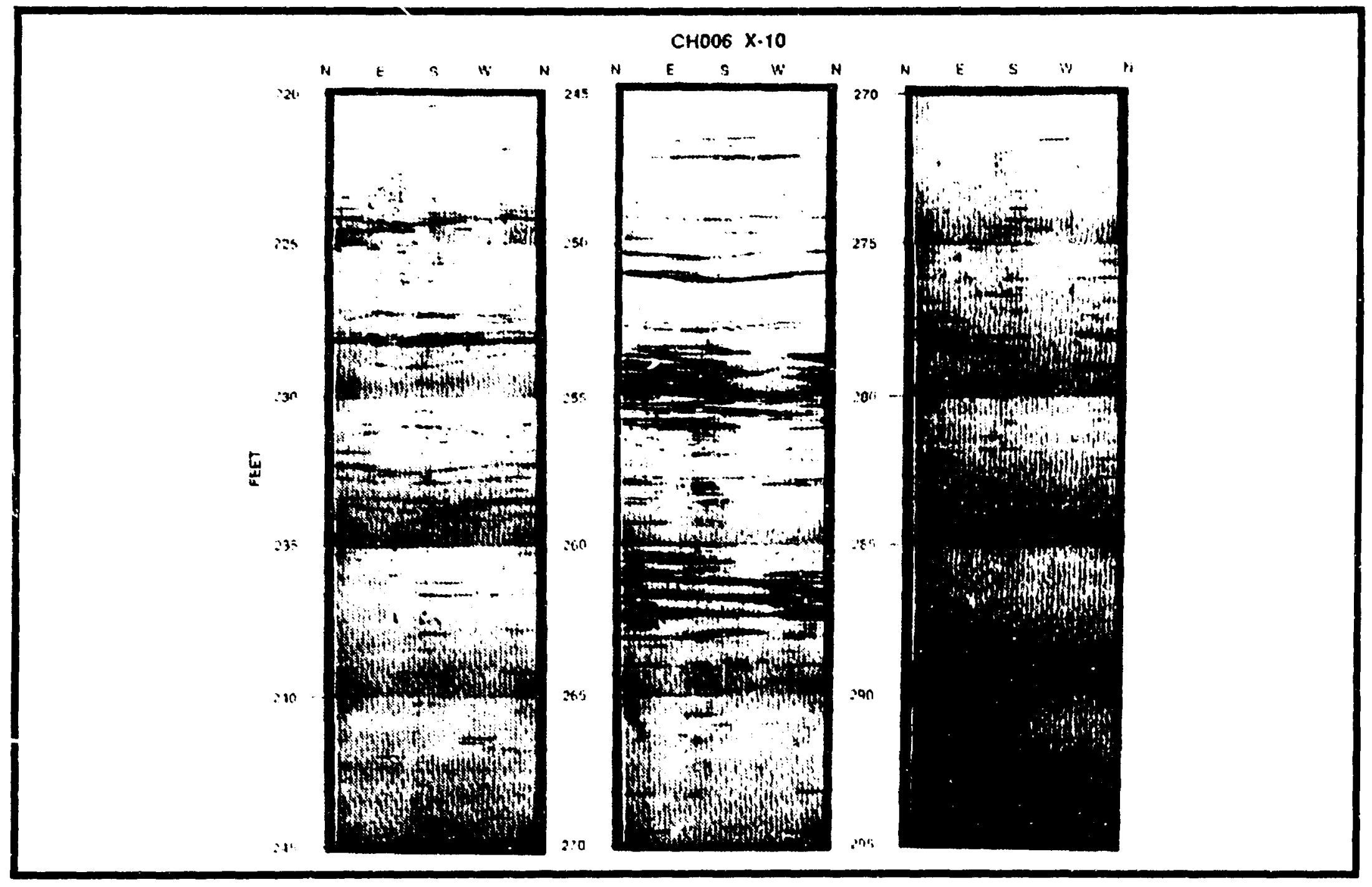

Fis. Al.3. (contioured). 


\section{A-1-15}

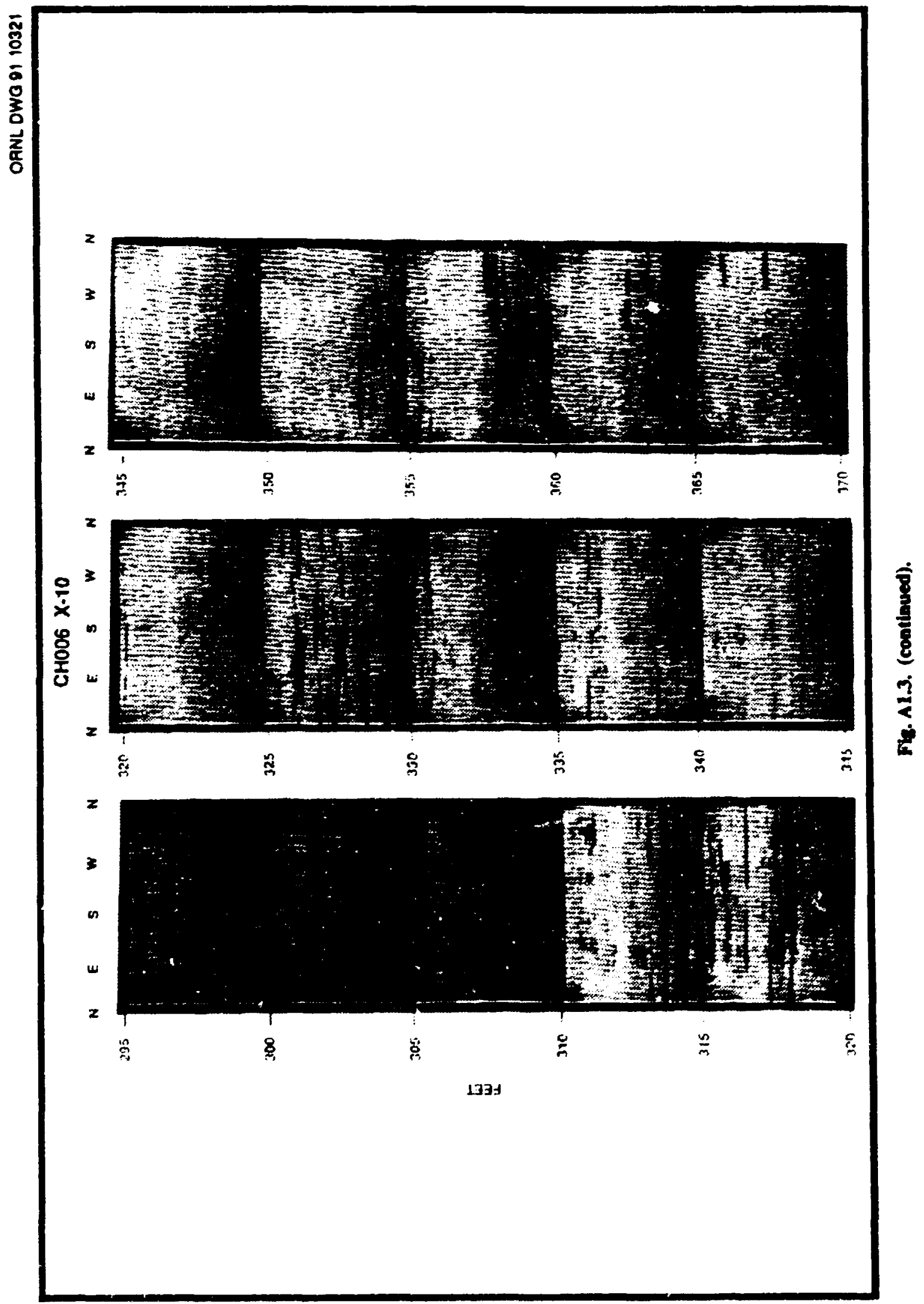




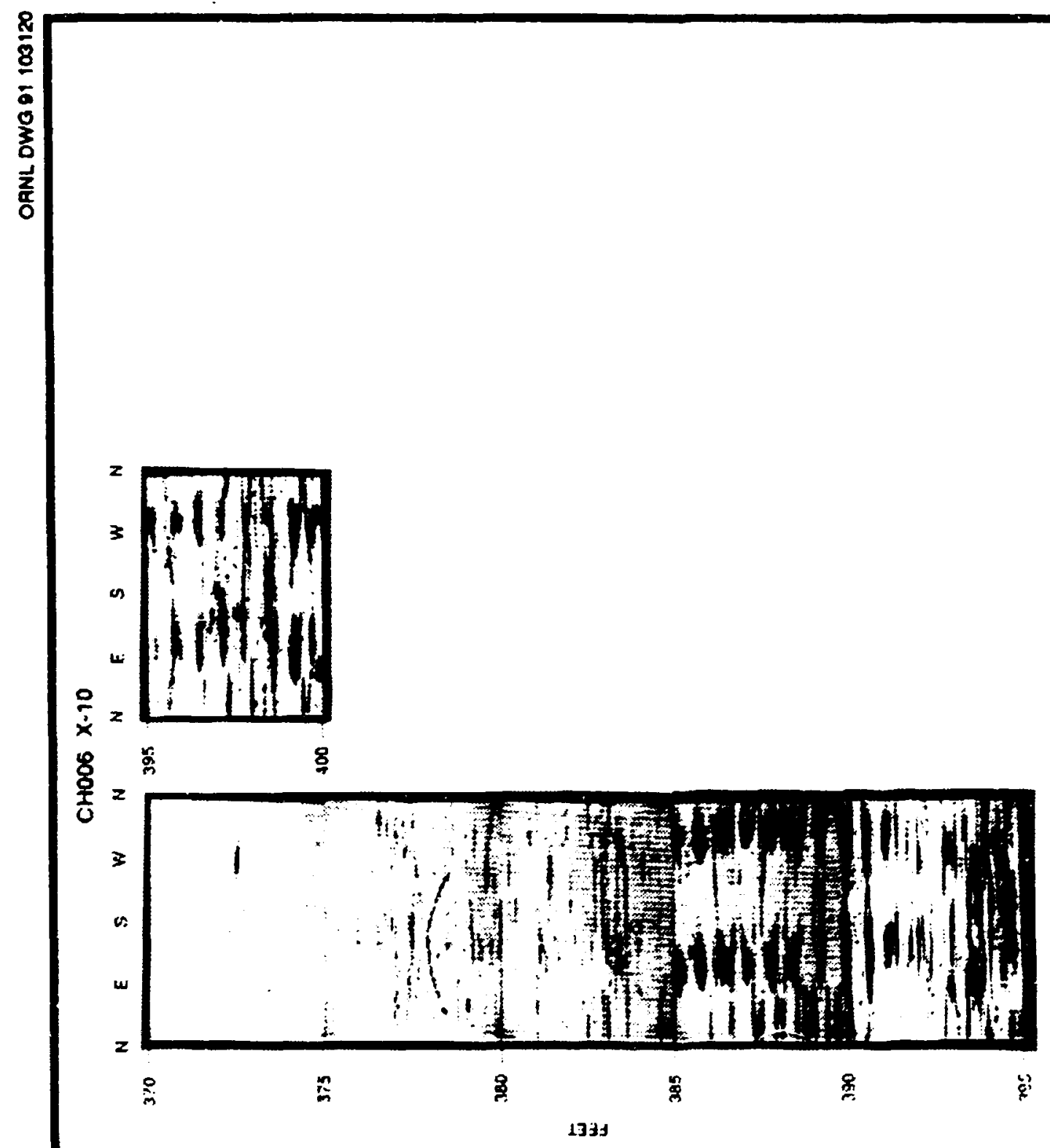

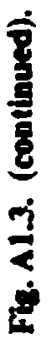


CH006 OWL Deviation Probe Data EAST - WEST CRCSS SECTION

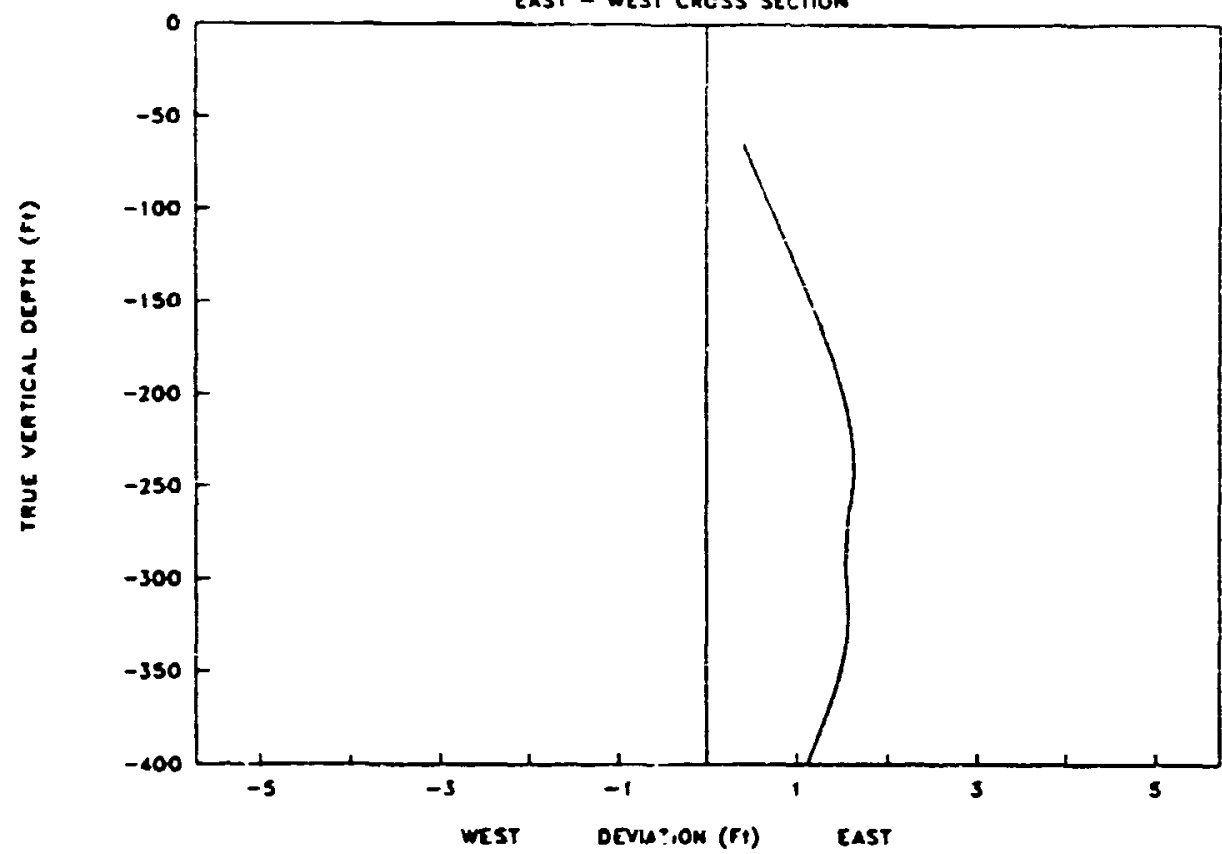

CHOO6 OWL Deviation Probe Data

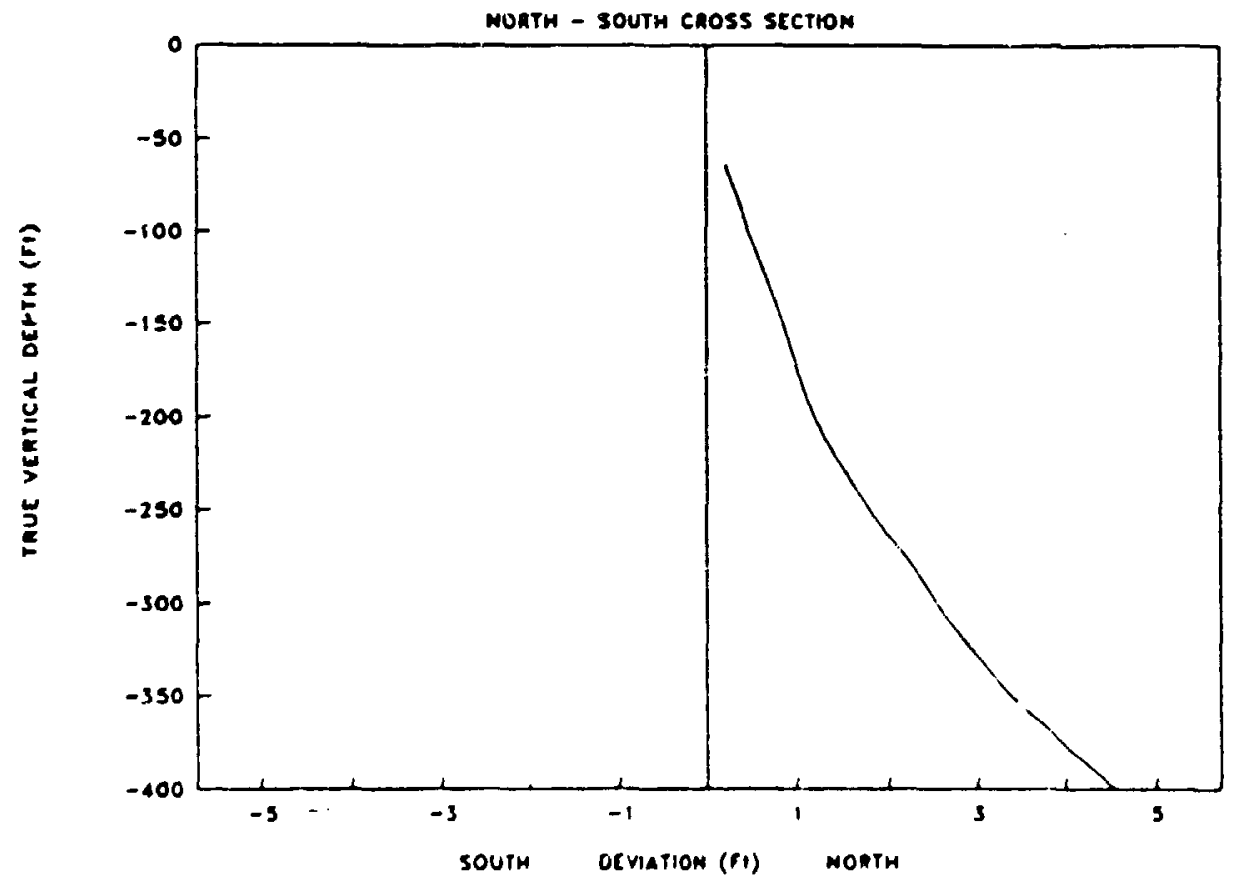

Fig. A 1.4. C:H006 JWL deviation probe data. 
CHOO6 OWL Deviation Probe Data

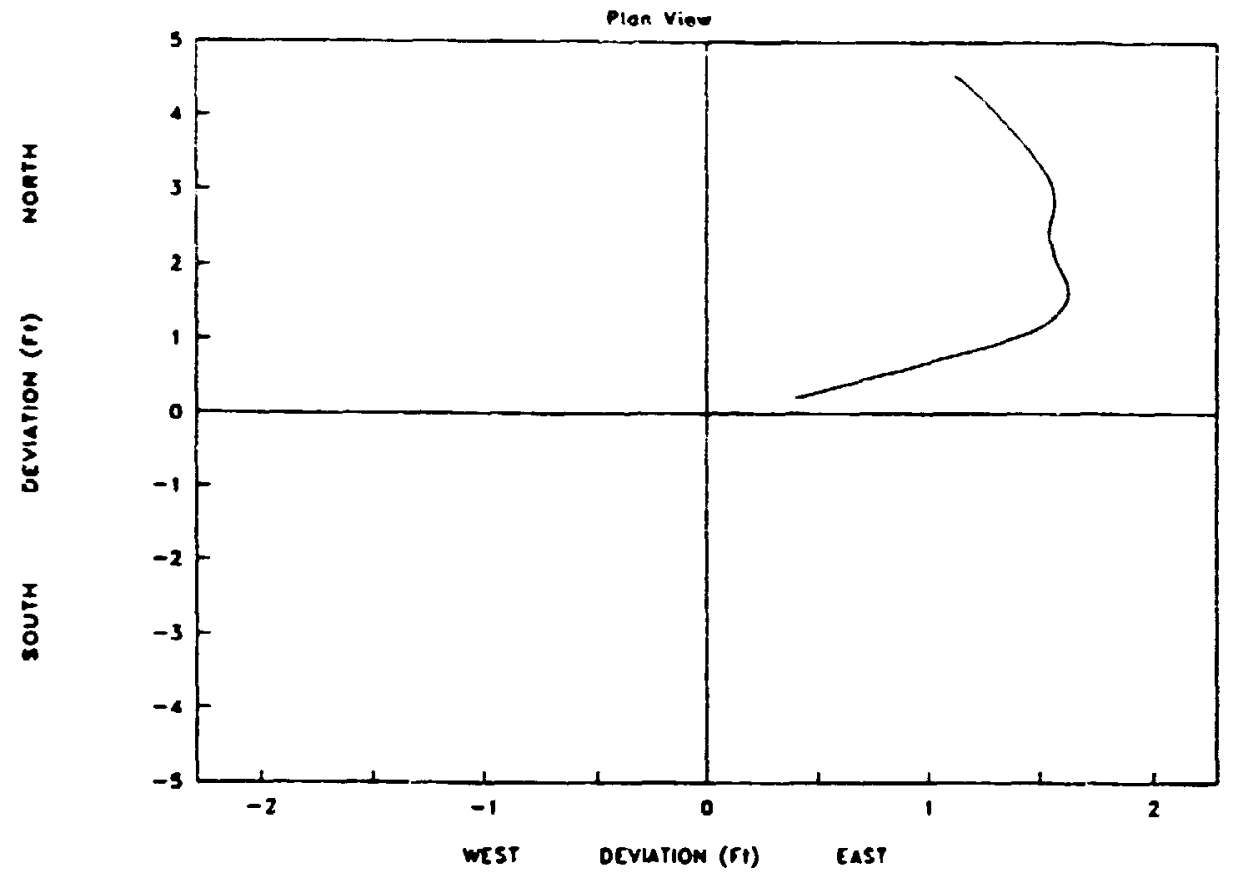

CHOO6 OWL Deviation Probe Data

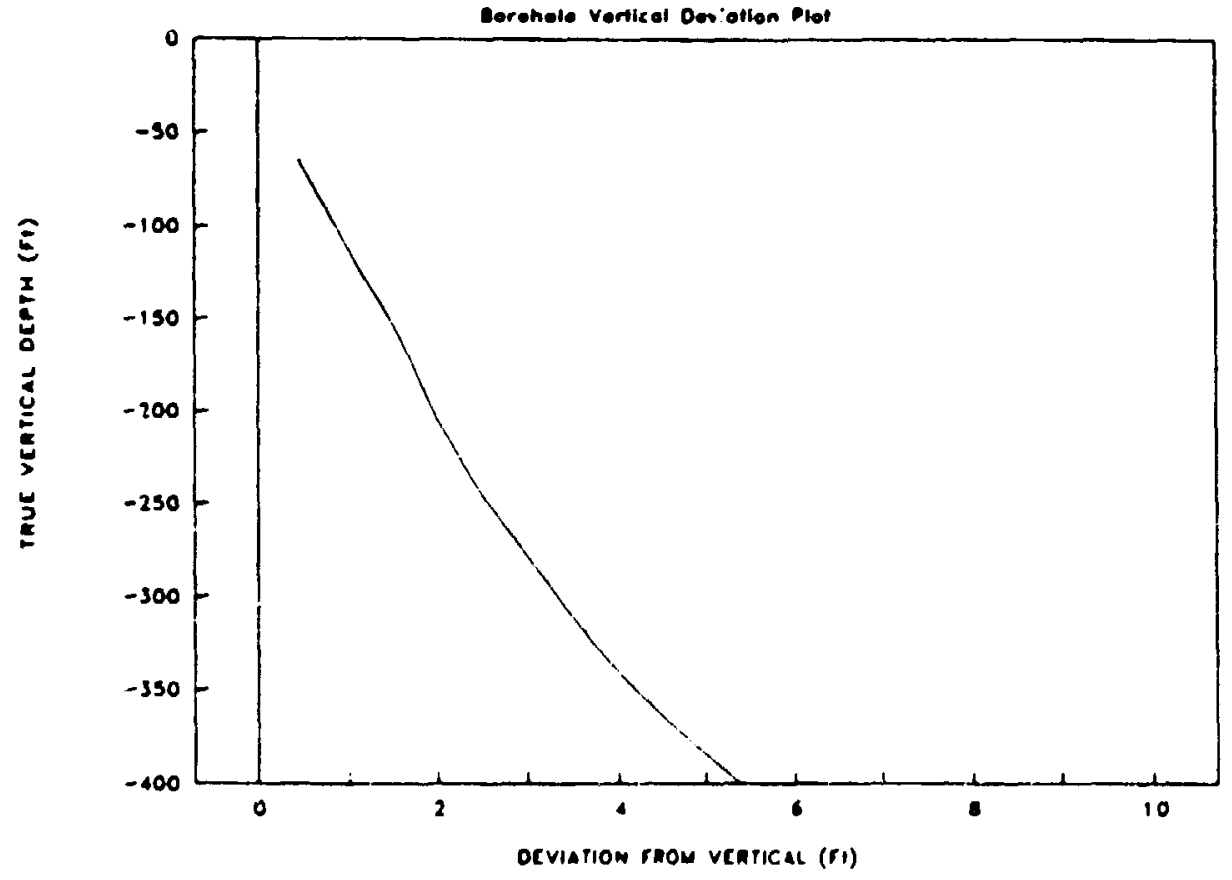

Fig. A 1.4. (continued). 
ATTACHMENT 2

CH07A-GEOPHYSICAL AND GEOLOGIC DATA

R:ITMITV 012 
Table A2.1. Summary of fractures identified in corehole CHO7A

\begin{tabular}{|c|c|c|c|c|c|c|c|c|c|c|}
\hline $\begin{array}{l}\text { Deps GS } \\
\text { (n) }\end{array}$ & $\begin{array}{c}\text { Goologic } \\
\text { unit }\end{array}$ & $\begin{array}{l}\text { Fractures } \\
\text { per food }\end{array}$ & BIITV & VDL & Caliper & Temperature & $\begin{array}{c}\text { Dekt } \\
\text { temperaturo }\end{array}$ & $\begin{array}{l}\text { Devintion } \\
\text { survey }\end{array}$ & SP & Comments \\
\hline $\begin{array}{l}28-29 \\
29-30\end{array}$ & D & 4 & & & & & & $\begin{array}{l}\mathbf{x} \\
\boldsymbol{x}\end{array}$ & & $\begin{array}{l}30-31^{\circ} \text {. BP, al. open to open } \\
33^{\circ} \text {, BP, si. open to open }\end{array}$ \\
\hline $32-33$ & & & & & & $\mathbf{x}$ & $\mathbf{x}$ & & & \\
\hline $34.6-35.6$ & & $?$ & & & & & & & & $29-32^{\circ}$, BP, open lo tight \\
\hline $35.6-36.6$ & & 6 & & & & & & & & Low angle, up to $30^{\circ}$, open to tipht \\
\hline $36.6-37.6$ & & 6 & & & & & & & & $30^{\circ}$, BP, open to tight \\
\hline $37.6-38.6$ & & 4 & & & & & $\mathbf{x}$ & & & $29-31^{\circ}$, BP, open to tight \\
\hline $38.6-39.6$ & & 2 & & & & & & & & $30^{\circ}$, BP, sl. open \\
\hline $39.6-10.6$ & & 4 & & & & & $\mathbf{x}$ & $\mathbf{x}$ & & Low anglo to $30^{\circ}$, al. open to tight \\
\hline $40.6-41.6$ & & 2 & & & & & & & & $30^{\circ}$, BP, si. open to tight \\
\hline$\$ 4-45$ & & & tov & & $\mathbf{x}$ & & & $\mathbf{x}$ & & \\
\hline 47.8 .48 .8 & & 2 & ...* & & $\mathbf{x}$ & & & $\mathbf{x}$ & $\mathbf{x}$ & $30^{\circ}$, BP, tight; low angle fracture surface, upen \\
\hline $50-51$ & & & $\mathbf{x}$ & & & B & $\mathbf{x}$ & & $\mathbf{x}$ & \\
\hline 51.1 .52 .1 & & 5 & $\mathbf{x}$ & $\mathbf{x}$ & $\mathbf{x}$ & B & $\mathbf{x}$ & $\mathbf{x}$ & & 30-31', BP, light and open \\
\hline $\begin{array}{l}52.1 .53 .1 \\
53.54\end{array}$ & & 2 & $\begin{array}{l}\mathbf{x} \\
\mathbf{x}\end{array}$ & & $x$ & $\begin{array}{l}\text { B } \\
\text { B }\end{array}$ & $\begin{array}{l}\mathbf{x} \\
\mathbf{x}\end{array}$ & & & $22-28^{\circ}$, BP, open \\
\hline 54.1 .55 .1 & & 3 & $\mathbf{x}$ & $\mathbf{x}$ & & & & $\mathbf{x}$ & & 32-35', BP, st. open to open \\
\hline $55.1-56.1$ & & 3 & $\mathbf{x}$ & & & & & & & $25.40^{\circ}$, BP, tight and open \\
\hline $58.1-57.1$ & & 2 & $\mathbf{x}$ & & & $\mathbf{x}$ & & $\mathbf{x}$ & & $25^{\circ}$. BP, tight \\
\hline 57.58 & & & $?$ & & & & & & & \\
\hline $58.1-59.1$ & & 2 & & $\mathbf{x}$ & $\mathbf{x}$ & & $\mathbf{x}$ & $\mathbf{x}$ & & $29^{\circ}, \mathrm{BP}$, tight \\
\hline 64.1 .65 .1 & & 2 & $\mathbf{x}$ & $\mathbf{x}$ & & $\mathbf{x}$ & $\mathbf{x}$ & $\mathbf{x}$ & $\mathbf{x}$ & $34^{\circ}$, BP, sl. open to tight \\
\hline $66-67$ & & & $\mathbf{x}$ & $\mathbf{x}$ & & B & & & & \\
\hline $67.1-68.1$ & & 4 & $\mathbf{x}$ & $\mathbf{x}$ & $\mathbf{x}$ & & & $\mathbf{x}$ & & $\begin{array}{l}30-32^{\circ} \text {, BP, al. open in tight. } 67.5-68.1 \text { - Driller } \\
\text { says either } v \text {, soli or a void }\end{array}$ \\
\hline $68.1-69.1$ & & 6 & $\mathbf{x}$ & $\mathbf{x}$ & & & & & & $\begin{array}{l}24-35^{\circ} \text {. BP, open; } \perp \text { to hodding, purtinlly healed. } \\
\text { almod illod with caleite eryatals }\end{array}$ \\
\hline $69.1-70.1$ & & 2 & & $\mathbf{x}$ & & $\mathbf{x}$ & & & & $\begin{array}{l}30^{\circ} \text {. BP, light; } \perp \text {. to hedding, partially healod, } \\
\text { almou fillod with calcite cryarals }\end{array}$ \\
\hline $70.1-71.1$ & & 2 & & & & $\mathbf{x}$ & & & & $25-32^{\circ}$, BP, al. open wo tight \\
\hline $71.1-72.1$ & & 5 & $\mathbf{x}$ & $\mathbf{x}$ & $\mathbf{x}$ & & & & & $30^{\circ}$, open to tight \\
\hline
\end{tabular}


Table A2.1 (continued)

\begin{tabular}{|c|c|c|c|c|c|c|c|c|c|c|}
\hline $\begin{array}{l}\text { Depth BGS } \\
\text { (n) }\end{array}$ & $\begin{array}{l}\text { Goologic } \\
\text { unix }\end{array}$ & $\begin{array}{l}\text { Fractures } \\
\text { per foot }\end{array}$ & BHTV & VDL & Caliper & Temperature & $\begin{array}{c}\text { Delha } \\
\text { temperature }\end{array}$ & $\begin{array}{l}\text { Deviation } \\
\text { survey }\end{array}$ & $\mathbf{S P}$ & Comments \\
\hline $72.1 \cdot 7.1$ & & 3 & $\mathbf{x}$ & & & & $\mathbf{x}$ & $\mathbf{x}$ & & 23-35 . BP, al. open to open \\
\hline $74.1-75.1$ & & 2 & $\mathbf{x}$ & & & $\mathbf{x}$ & $\mathbf{x}$ & & & $37^{\circ}$, BP, s1, open; $22^{\circ}$, low angle frecture, open \\
\hline $76.1-77.1$ & & 2 & & & & & $\mathbf{x}$ & & & $30^{\circ}$, BP, open; bw angle frecture, open \\
\hline $7.1 \cdot 78.1$ & & 3 & & & & $\mathbf{x}$ & $\mathbf{x}$ & & & 28-32', BP, sl. open to tight \\
\hline $80-81$ & & & $\mathbf{x}$ & $\mathbf{x}$ & $\mathbf{x}$ & $\mathbf{x}$ & & $\mathbf{x}$ & & \\
\hline $82.1-83.1$ & & 2 & & & & B & $\mathbf{x}$ & & & $\begin{array}{l}32^{\circ}, \text { BP, al. open; low angle fracture, al. opent to } \\
\text { tight }\end{array}$ \\
\hline $84.1-85.1$ & & 2 & $\mathbf{x}$ & & $\mathbf{x}$ & B & & & & 35', BP, open and tight \\
\hline $85.1-86.1$ & & 2 & $?$ & $\mathbf{x}$ & & $\mathbf{x}$ & $\mathbf{x}$ & & & $25-30^{\circ}$, BP, open \\
\hline 86.1-87.1 & & 3 & & & & & & & & $30-32^{\circ}$. BP, open and tight \\
\hline 87.1-88.1 & & 2 & ? & $\mathbf{x}$ & & & & $\mathbf{x}$ & & 28-33', BP, tight \\
\hline $89.1-90.1$ & & 3 & $?$ & $\mathbf{x}$ & $\mathbf{x}$ & B & & & $\mathbf{x}$ & $30-34^{\circ}$, BP, open at $-89.5 \AA, 1-\AA$ void zone \\
\hline $90.1-51.1$ & & $\mathbf{J}$ & $\mathbf{x}$ & $\mathbf{x}$ & & B & $\mathbf{x}$ & & $\mathbf{x}$ & $31^{\circ}$, BP, open and tight \\
\hline$\$ 1.1 .92 .1$ & & 3 & $?$ & $?$ & & B & & & $\mathbf{x}$ & $31-32^{\circ}$, BP, open and tight \\
\hline $93.1-94.1$ & & 3 & $\mathbf{x}$ & $\mathbf{x}$ & & $\mathbf{x}$ & & & & 33-35'. BP, open and light \\
\hline $94-95$ & & & $\mathbf{x}$ & $\mathbf{x}$ & & $\mathbf{x}$ & & & & \\
\hline $95.9-96.9$ & & 2 & $\mathbf{x}$ & & & & & & & 29. BP, open; high angle fracture surface, tiglth \\
\hline $97-98$ & & & $\mathbf{x}$ & & & B & & $\mathbf{x}$ & & \\
\hline $99.9-100.9$ & & 4 & $\mathbf{x}$ & & $\mathbf{x}$ & & & & & $30^{\circ}, \mathrm{BP}$, al, open to light \\
\hline $100.9-101.9$ & & $\mathbf{3}$ & $\mathbf{x}$ & $\mathbf{x}$ & & & $\mathbf{x}$ & $\mathbf{x}$ & $\mathbf{x}$ & $30^{\circ}, \mathrm{BP}$, light \\
\hline $101.9-102.9$ & & & $\mathbf{x}$ & $\mathbf{x}$ & & & & & & $\begin{array}{l}29^{\circ}, \text { BP, al. open to open; } \perp \text { to bodding (ttrilie-dip } \\
\text { set), light }\end{array}$ \\
\hline $102.9-103.9$ & & 3 & & $\mathrm{x}$ & $x$ & & & & $\mathbf{x}$ & \\
\hline $109-110$ & & & $?$ & $\mathbf{x}$ & $\mathbf{x}$ & B & & & & \\
\hline $112-1 i 3$ & & & & & $\mathbf{x}$ & & $\mathbf{x}$ & & & \\
\hline $118 \cdot 119$ & & & $?$ & $\mathbf{x}$ & & & $\mathbf{x}$ & & & \\
\hline $119.9-120.9$ & & 5 & $x$ & $\mathbf{x}$ & & $x$ & $x$ & $\mathbf{x}$ & & $\begin{array}{l}\text { Fraclured/bmken cavity, heavy calcile } \\
\text { mineralization; } 1 \text { partially healed } \perp \text { fracture }\end{array}$ \\
\hline 123.124 & & & 1 & & & & & $\mathbf{x}$ & & \\
\hline $1959-126.9$ & & 2 & & & & $\mathbf{x}$ & & & & nip-nornal, parallel fracture set, tight \\
\hline
\end{tabular}


Table A2.1 (continued)

\begin{tabular}{|c|c|c|c|c|c|c|c|c|c|c|}
\hline $\begin{array}{l}\text { Depth BGS } \\
\text { (n) }\end{array}$ & $\begin{array}{l}\text { Geobgic } \\
\text { unix }\end{array}$ & $\begin{array}{l}\text { Fractires } \\
\text { per food }\end{array}$ & BHTV & VDL & Caliper & Temperature & $\begin{array}{c}\text { Detha } \\
\text { comperalure }\end{array}$ & $\begin{array}{c}\text { Deviution } \\
\text { ourvey }\end{array}$ & SP & Comments \\
\hline $126.9-127.9$ & & 2 & $?$ & & & $\mathbf{x}$ & $\mathbf{x}$ & & & $\begin{array}{l}30^{\circ} \text {. BP, tight; high angle fracture surface, chkite } \\
\text { mineralization, open }\end{array}$ \\
\hline $127.9-128.9$ & & & $?$ & & $\mathbf{x}$ & B & & $\mathbf{x}$ & & \\
\hline $129.9-130.9$ & & & $\mathbf{x}$ & $\mathbf{x}$ & & & $\mathbf{x}$ & & & \\
\hline $130.9-131.9$ & & $2-3$ & $\mathbf{x}$ & $\mathbf{x}$ & $\mathbf{x}$ & $\mathbf{x}$ & $\mathbf{x}$ & & & $\begin{array}{l}\text { Dip-normal, dip-panallel fracture set, v. heavy cialcite } \\
\text { mineratization, open }\end{array}$ \\
\hline 133-134 & & & $\mathbf{x}$ & & & $\mathbf{x}$ & $\mathbf{x}$ & & & \\
\hline 134.9 .135 .9 & & 2 & $?$ & & & & & $\mathbf{x}$ & & \\
\hline $135.9-136.9$ & & 2 & $?$ & & & & $\mathbf{x}$ & & & \\
\hline $137.9-133.9$ & & & $\mathbf{x}$ & & & $\mathbf{x}$ & $\mathbf{x}$ & & & \\
\hline $138.9-139.9$ & & $\mathbf{3}$ & $\mathbf{x}$ & & & & & & & \\
\hline $140.9-141.9$ & & 2 & & & & B & & & & \\
\hline 143.144 & & & $\mathbf{x}$ & & & & & $\mathbf{x}$ & & 3 \\
\hline $151-152$ & c & & $\mathbf{x}$ & & $\mathbf{s}$ & & $\mathbf{s}$ & & & t \\
\hline $155-156$ & & & $\mathbf{x}$ & & & & $\mathbf{x}$ & & & $39^{\circ}, \mathrm{BP}$, tight \\
\hline $156.6-157.6$ & & 2 & $\mathbf{x}$ & $\mathbf{x}$ & & & & & & \\
\hline $157.6-158.6$ & & 4 & $\mathbf{x}$ & $\mathbf{x}$ & & B & & & & $34-37^{\circ}$, BP, open to tight \\
\hline $158.6-159.6$ & & 2 & $\mathbf{x}$ & $\mathbf{x}$ & & & & $\mathbf{x}$ & & $34^{\circ}$, BP, tight \\
\hline $159.6-160.6$ & & & $?$ & $\mathbf{x}$ & & & & $\mathbf{x}$ & & \\
\hline $160.6-161.6$ & & & $?$ & & & & $\mathbf{x}$ & & & \\
\hline $162-163$ & & & $\mathbf{x}$ & $\mathbf{x}$ & $\mathbf{x}$ & $\mathbf{x}$ & & & & $34^{\circ}$. BP, sl. open to open \\
\hline $163.6-164.6$ & & 2 & $?$ & $\mathbf{x}$ & & & & & & \\
\hline $165-166$ & & & $x$ & & & & $\mathbf{x}$ & & & \\
\hline $166-167$ & & & $\mathbf{x}$ & & & & $\mathrm{x}$ & & & $30-35^{\circ}$, BP, open to tight \\
\hline
\end{tabular}


Table A2.1 (consinued)

\begin{tabular}{|c|c|c|c|c|c|c|c|c|c|c|}
\hline $\begin{array}{l}\text { Depth BGS } \\
\text { (A) }\end{array}$ & Goobgix & $\begin{array}{l}\text { Frncturea } \\
\text { per fool }\end{array}$ & BHTV & VDL & Caliper & Temporeture & $\begin{array}{c}\text { Deta } \\
\text { comperature }\end{array}$ & $\begin{array}{l}\text { Deniwtion } \\
\text { eurvey }\end{array}$ & SP & Comnerete \\
\hline $167.6-161.6$ & & 2 & & & & B & & $x$ & & \\
\hline $168.6-109.6$ & & 3 & $\mathbf{x}$ & & & $\mathbf{x}$ & & $\mathbf{x}$ & & $24-30^{\circ}$. BP, sl. open to open \\
\hline 17.178 & & & $\begin{array}{c}x \\
+++\end{array}$ & $\mathbf{x}$ & $\mathbf{x}$ & & & & & \\
\hline
\end{tabular}

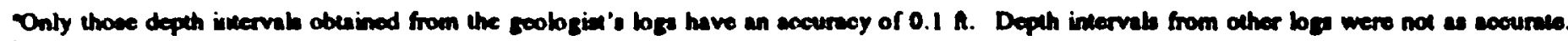

From reobegiat's los.

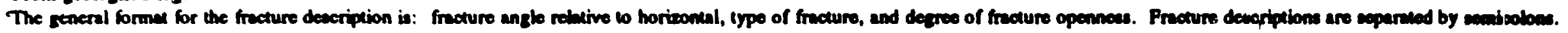

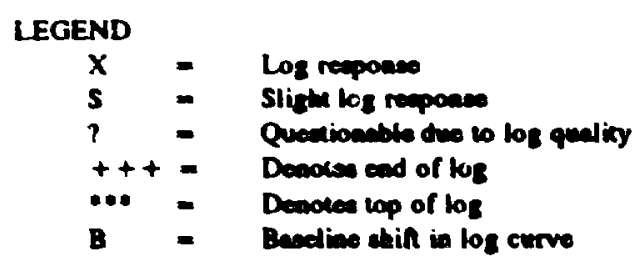

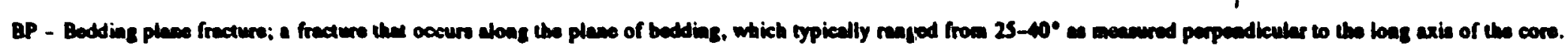

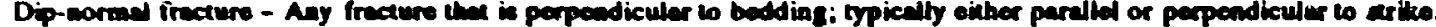

Dip-paralel frecture - Any fracture then is parelld to bedding.

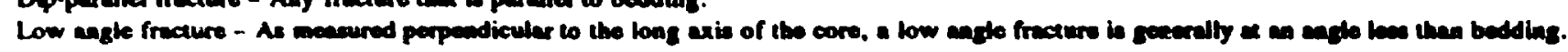

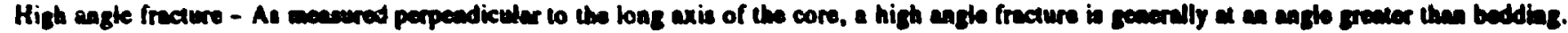

6. $\perp$ - A dip-nornel frecture; perpesdicular to bedding. 


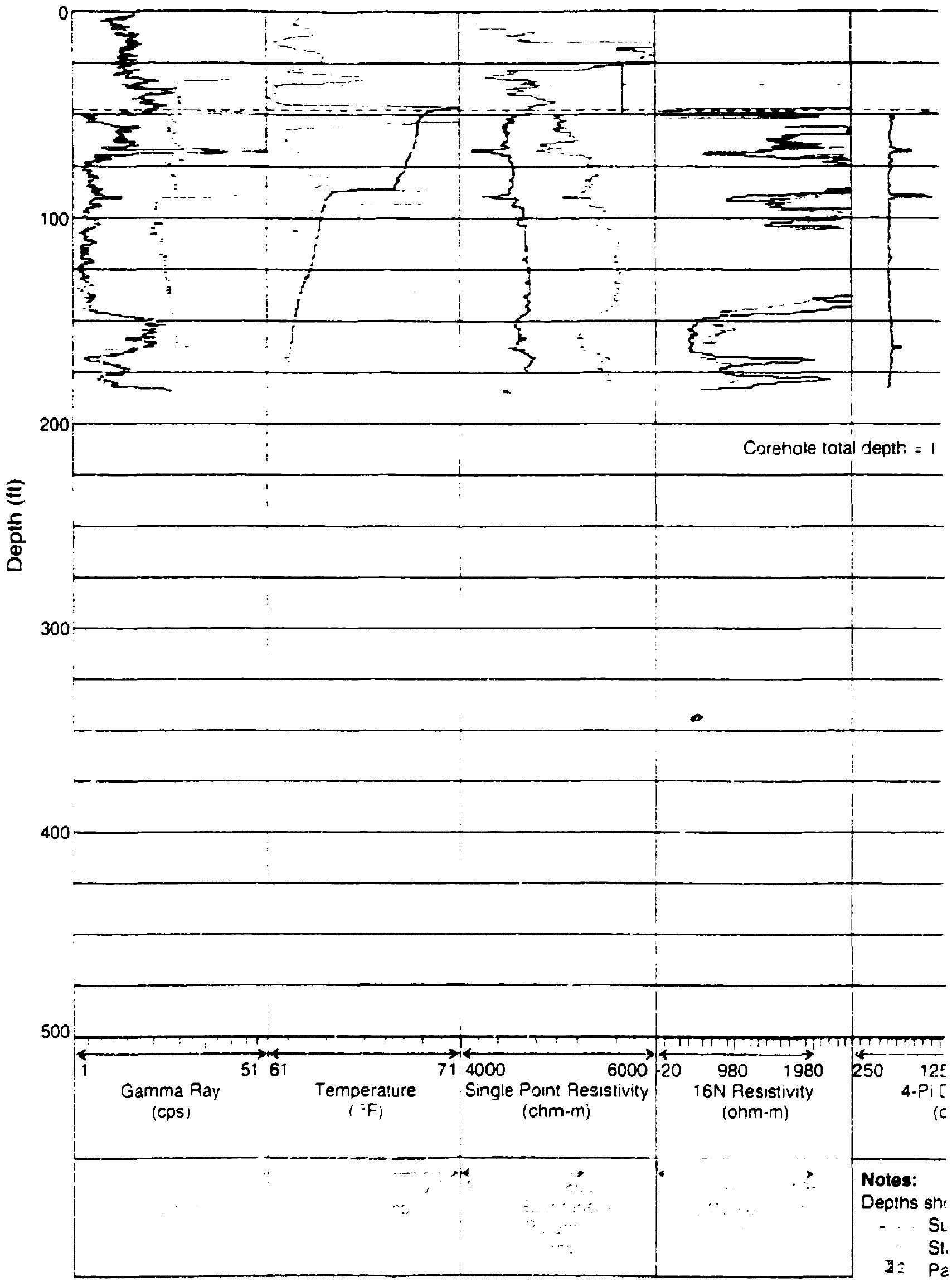




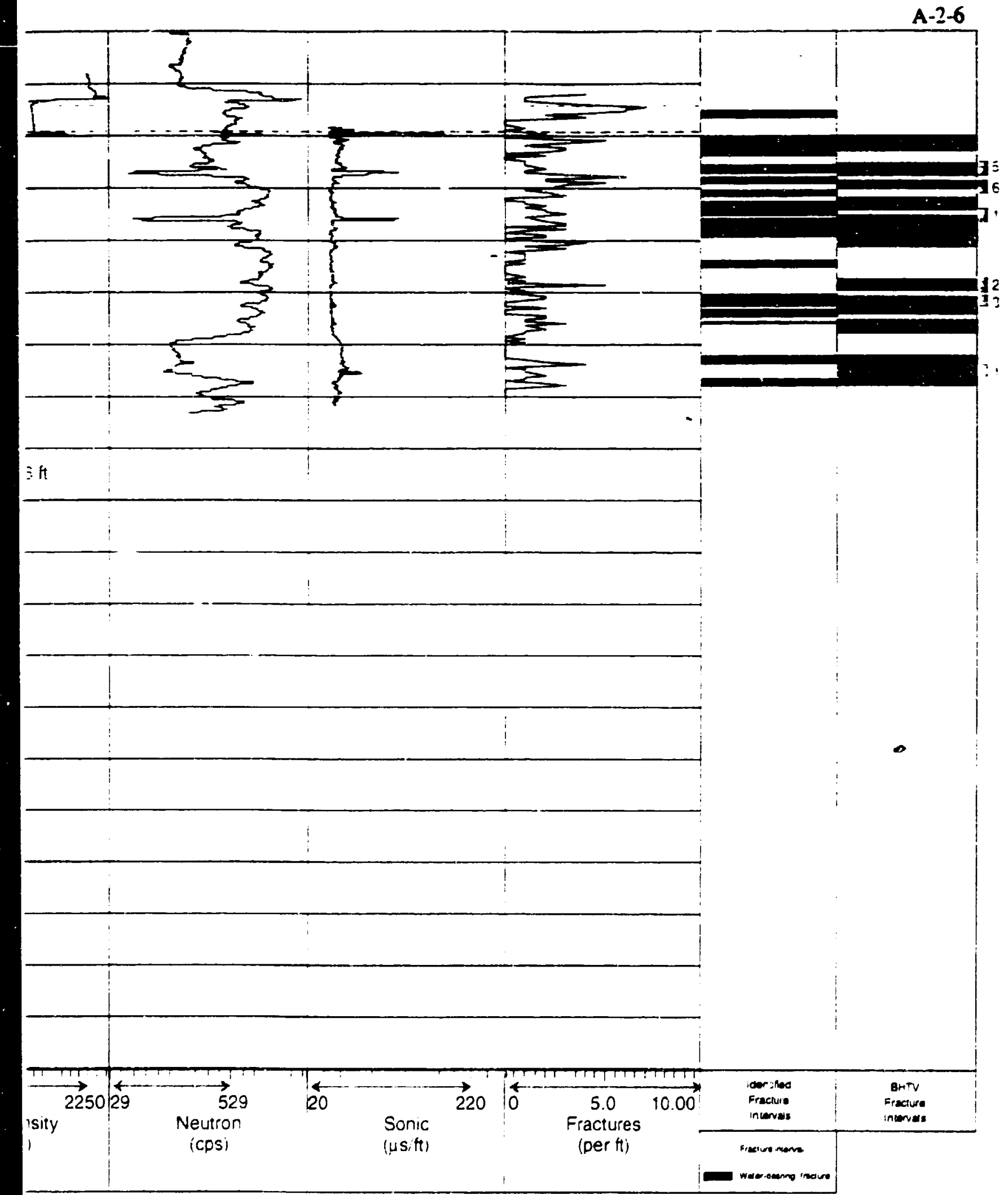

7 are trom ground surface

ce casing depth $=34.6 \mathrm{ft}$

; water level at lime of logging $=48.45 \mathrm{H}$

er test interval

Fig. 12.1. CH007 A borehole geophysical logs. 


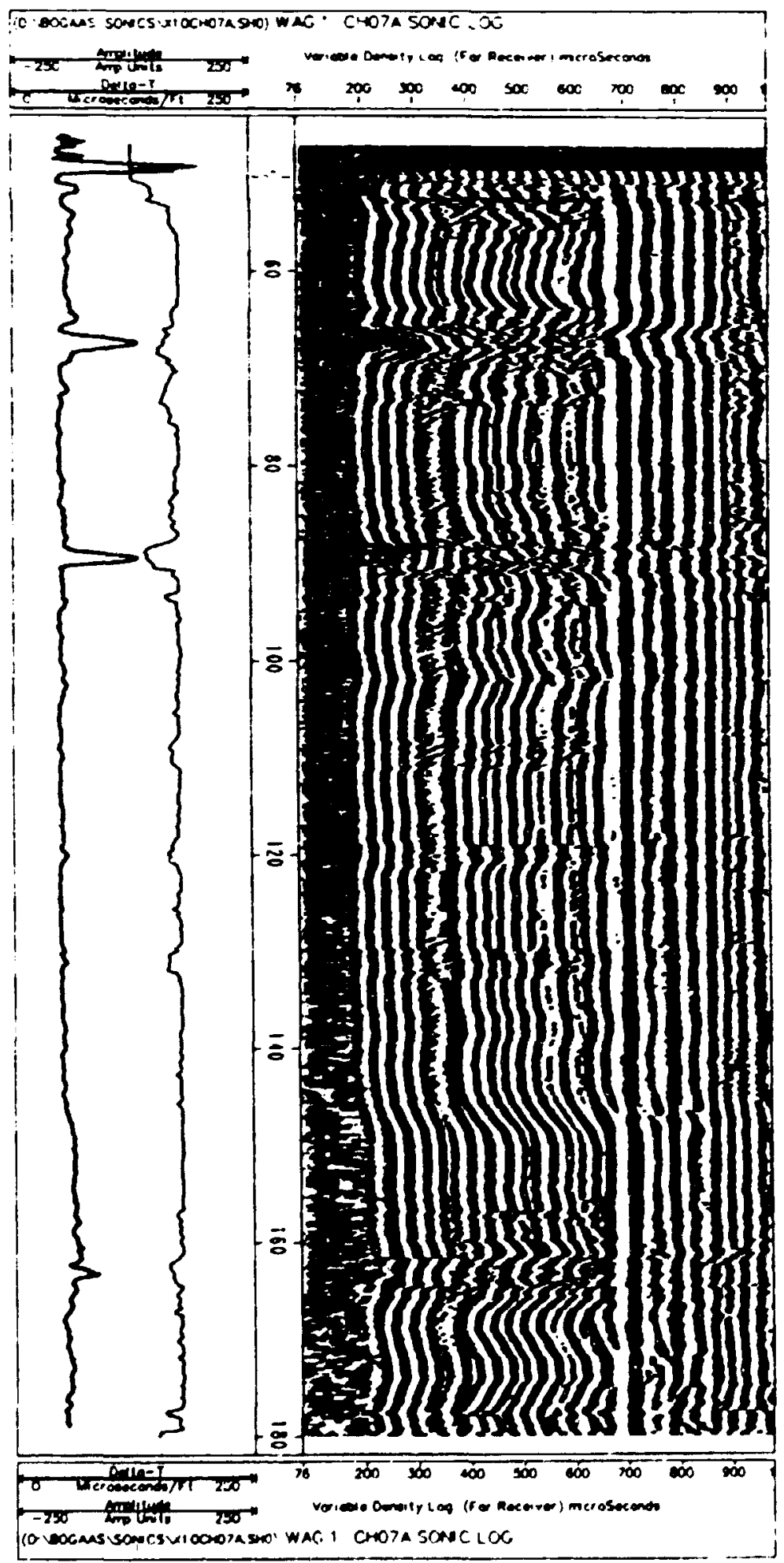

Fig. A2.2. CH07A variable density (acoustic) log. 


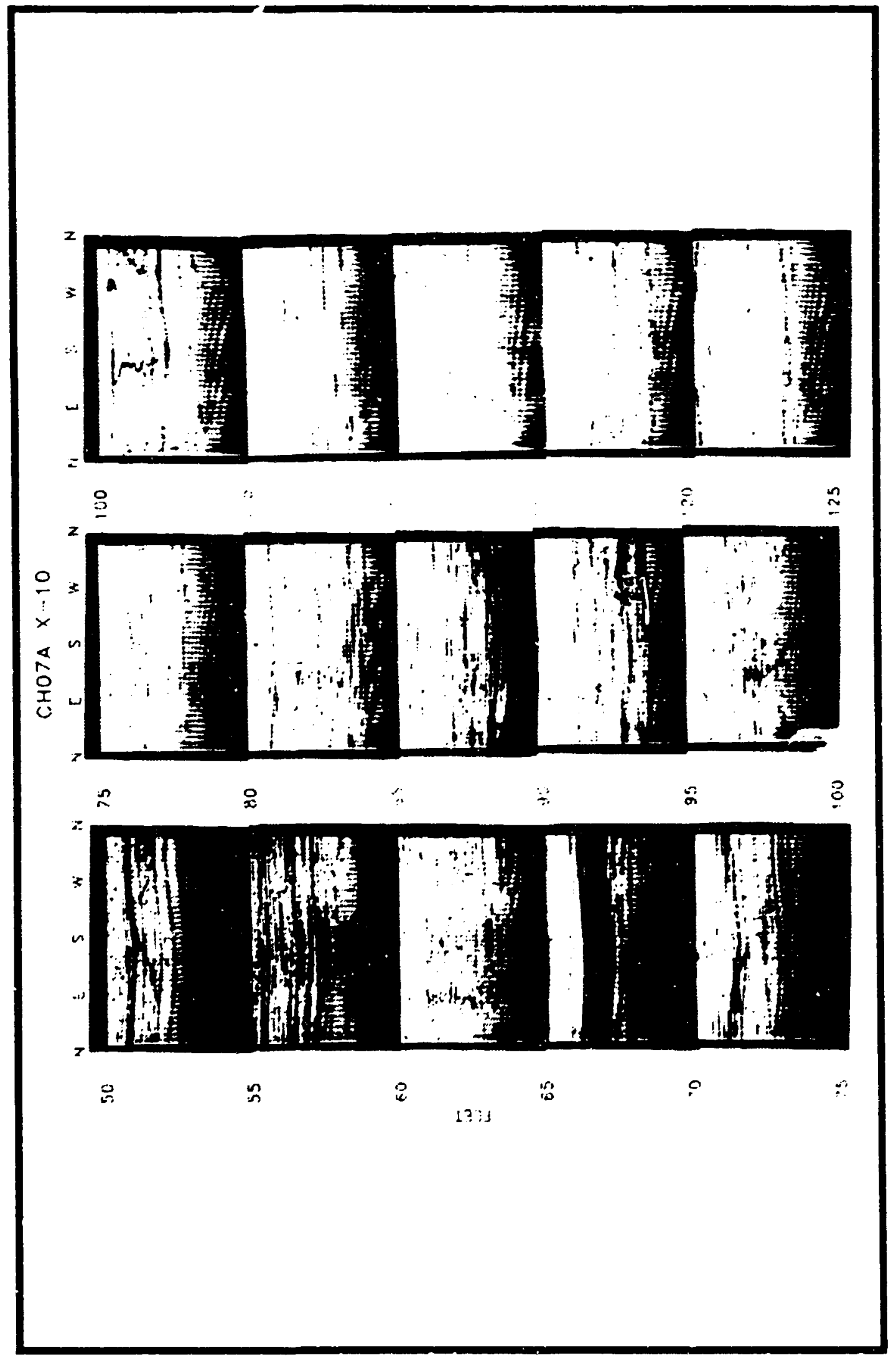

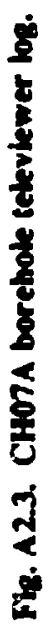




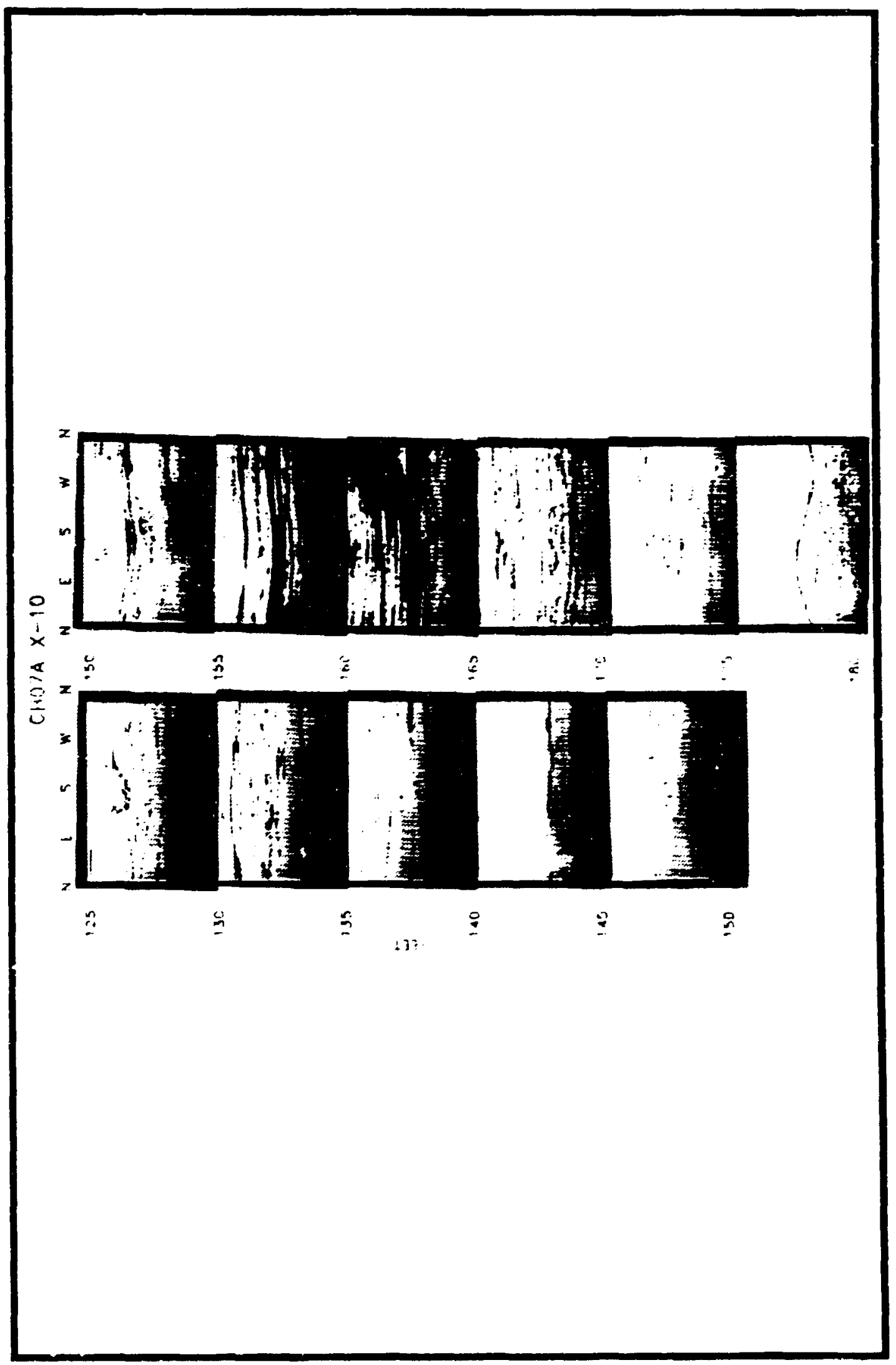

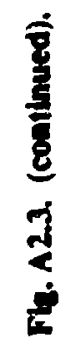


CH07A OWL Deviation Probe Data

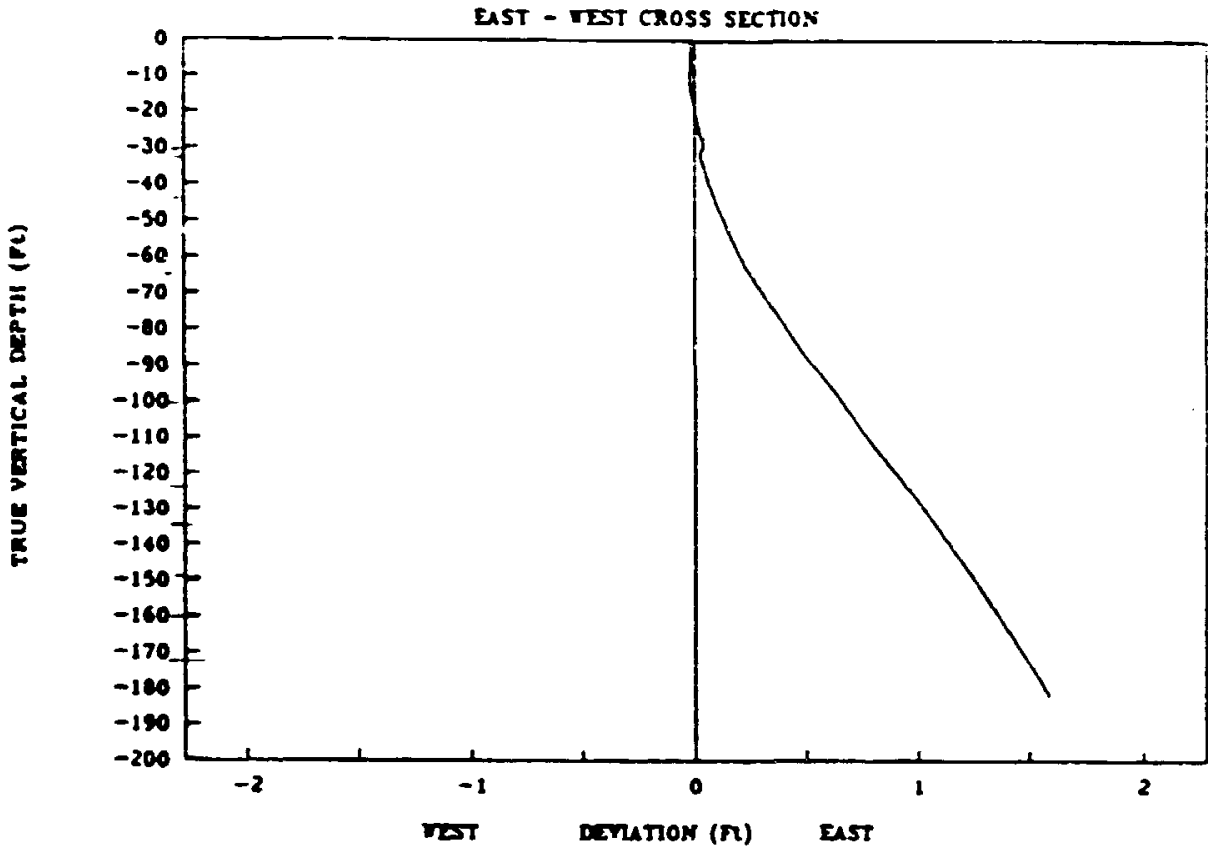

CH07A OWL Deviation Probe Data

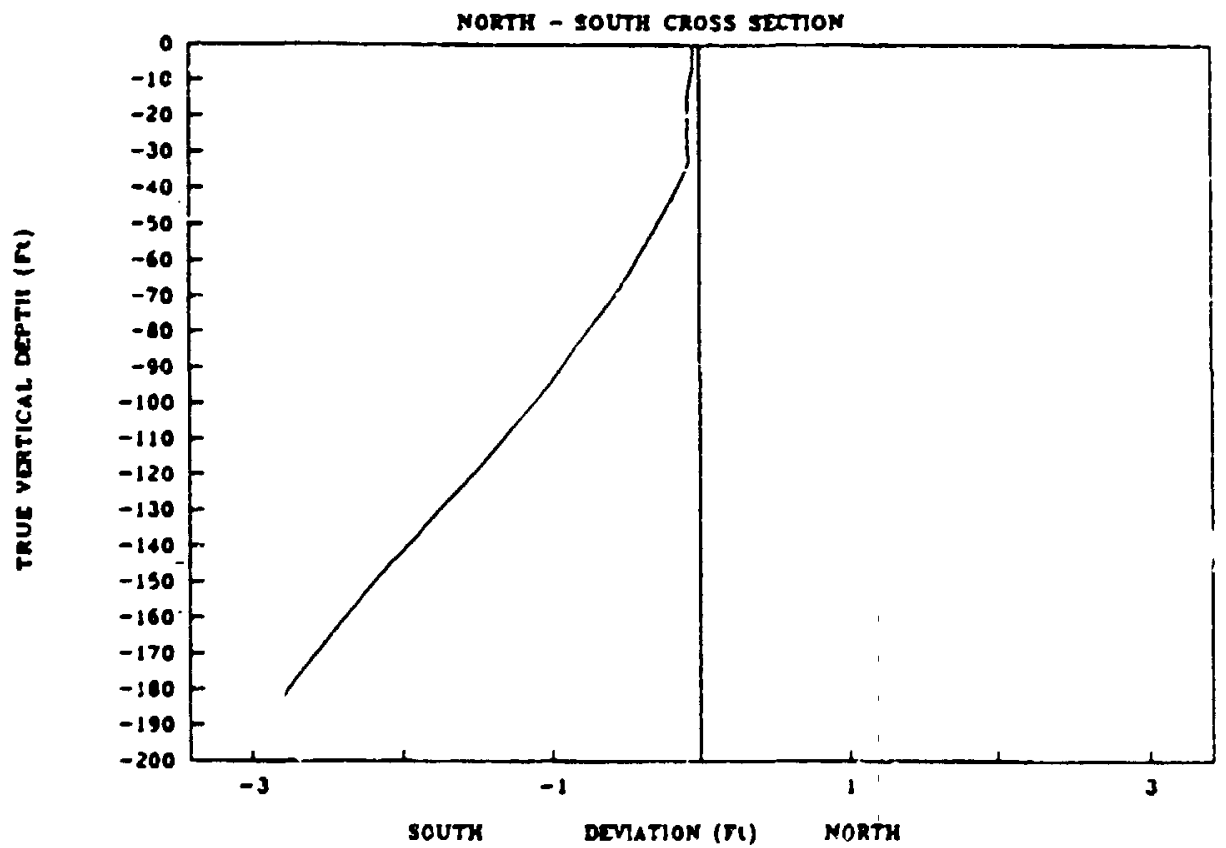

Fig. A2.4. CH007A OWL deviation probe data. 
CHOTA OWL Deviation Probe Data

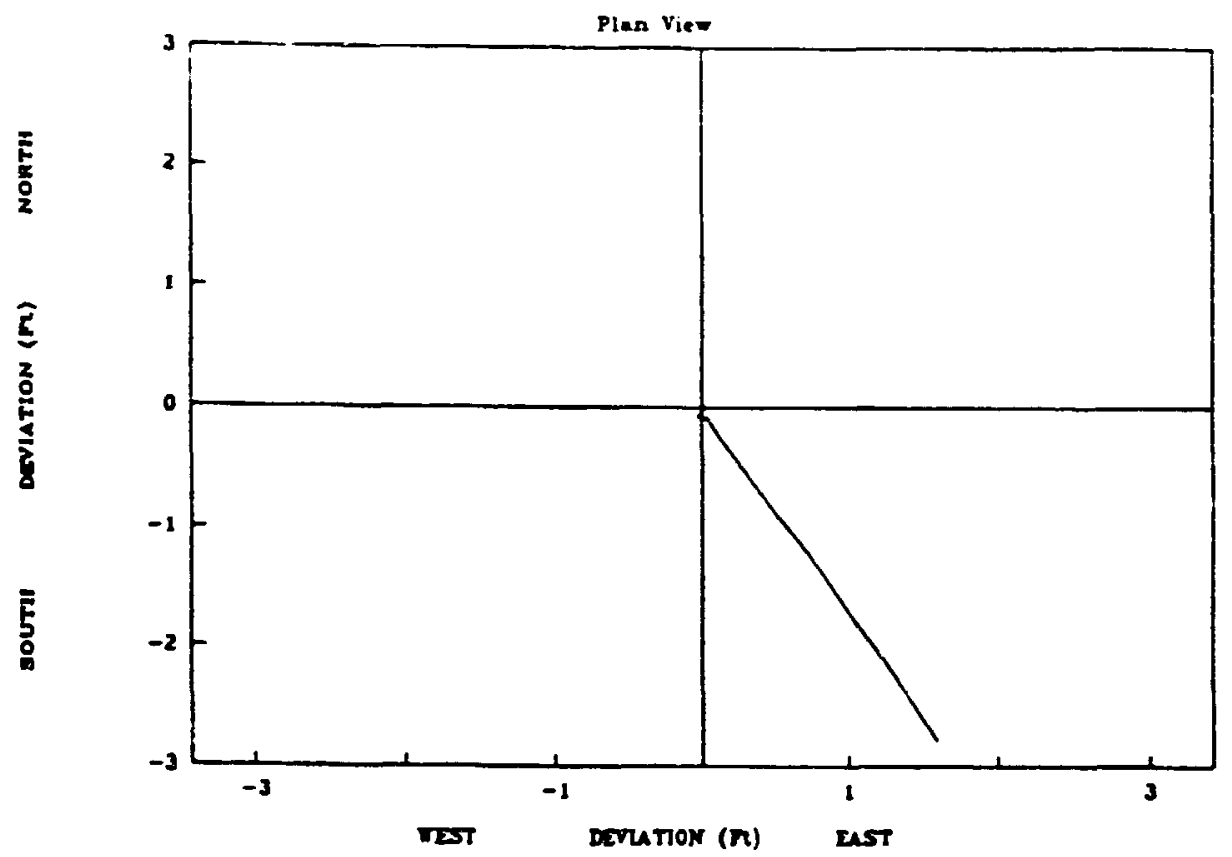

CH07A OWL Deviation Probe Data

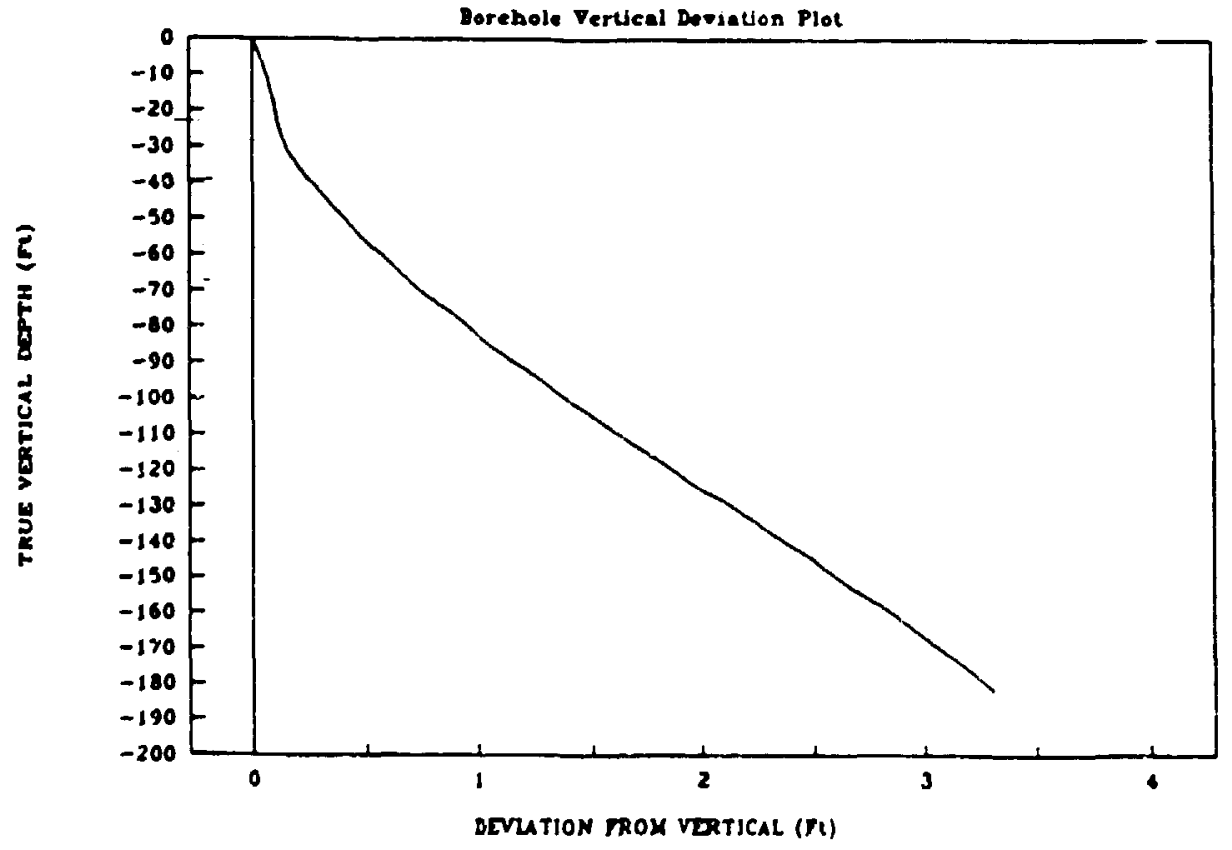

Fig. A2.4. (continued). 
ATTACHMENT 3

CHOO9-GEOPHYSICAL AND GEOLOGIC DATA

R:TnMTM-12 
Table A3.1. Surmary of fractures identified in corchole CHCos

\begin{tabular}{|c|c|c|c|c|c|c|c|c|c|c|}
\hline $\begin{array}{l}\text { Depth BGS } \\
\text { (A) }\end{array}$ & $\begin{array}{l}\text { Geologic } \\
\text { unit }\end{array}$ & $\begin{array}{l}\text { Fncturea } \\
\text { per fool }\end{array}$ & BHTV & VDL & Caliper & Temperaluie & $\begin{array}{c}\text { Dehs } \\
\text { temperature }\end{array}$ & $\begin{array}{c}\text { Deviation } \\
\text { survey }\end{array}$ & SP & Cummenis \\
\hline & & & $* * *\left(15^{\circ}\right)$ & & & & & & & \\
\hline 33-34 & G & 4 & $\mathbf{x}$ & $\mathbf{x}$ & & & $\mathbf{x}$ & & & $30^{\circ}$, BP, open \\
\hline $34-35.1$ & & 3 & $\mathbf{x}$ & & & & & & & $20-30^{\circ}$, BP, open \\
\hline 35-36 & & & $\mathbf{x}$ & & & & & & & \\
\hline $36-37$ & & 2 & $\mathbf{x}$ & & & & $\mathbf{x}$ & & & $30^{\circ}$, open to light \\
\hline 37.38 & & 3 & & & & & & & & $30^{\circ}$, open to tiefte \\
\hline 38-39 & & 4 & $\mathbf{x}$ & $\mathbf{x}$ & & & & & & $30^{\circ}$.opn \\
\hline $39-40$ & & 8 & $\mathbf{x}$ & $\mathbf{x}$ & & & & & & 30-35 , bP, open; $\perp$ to BP, tizeth \\
\hline $40-41$ & & 5 & $\mathbf{x}$ & $\mathbf{x}$ & & & $\mathbf{x}$ & & & 25-30', BP, open to tight \\
\hline $41-42$ & & 2 & $\mathbf{x}$ & & & & & & & $25 \cdot, \mathrm{BP}$ \\
\hline $42-43$ & & 3 & $x$ & $\mathbf{x}$ & & & & & & 20-40', BP, open to tight \\
\hline $43-4$ & & 3 & $\mathbf{x}$ & $\mathbf{x}$ & & & & & & $30^{\circ}$, BP, open \\
\hline$+4-45$ & & & $\mathbf{x}$ & & & & & & & \\
\hline $45-46$ & & 2 & $x$ & $\mathbf{x}$ & & & $\mathbf{x}$ & & & $40^{\circ}$, BP, open \\
\hline $46-47$ & & 2 & $\mathbf{x}$ & $\mathbf{x}$ & & & & & & $35^{\circ}$, BP, cpen to al. open \\
\hline $47-48$ & & 2 & $\mathbf{x}$ & $\mathbf{x}$ & & & $\mathbf{x}$ & & & $30-40^{\circ}$. BP, open to lighe \\
\hline $48-49$ & & 5 & $x$ & $\mathbf{x}$ & & & & & & $30-40^{\circ}$, BP, open \\
\hline 49.50 & & 2 & $\mathbf{x}$ & & & & $\mathbf{x}$ & & & $35^{\circ}$, BP, npen \\
\hline so-s1 & & 4 & $\mathbf{x}$ & $\mathbf{x}$ & & & $\mathbf{x}$ & $\mathbf{x}$ & & $20-40^{\circ}$, BP, open \\
\hline $51-52$ & & 4 & $\mathbf{x}$ & $\mathbf{x}$ & & & $x$ & & & $30-40^{\circ}$, BP, open \\
\hline 52.53 & & 3 & $\mathbf{x}$ & $x$ & & & & & & $30-45^{\circ}$. BP, sl. open to open \\
\hline $53-54$ & & 3 & & & & & & $\mathbf{x}$ & & $35^{\circ}$, BP, al. open to open \\
\hline 54.55 & & & $s$ & & & & $\mathbf{x}$ & & & \\
\hline $56-57$ & & 3 & $\mathbf{x}$ & $\mathbf{x}$ & & $\mathbf{x}$ & $\mathbf{x}$ & & & $25.35^{\circ}$. BP, light to \&l, open \\
\hline $5 ? .58$ & & & $x$ & & & $\mathbf{x}$ & $x$ & & $\mathbf{x}$ & \\
\hline $58-59$ & & 3 & $\mathbf{x}$ & & & & & & & $30-50^{\circ}$. BP, open \\
\hline $59-60$ & & & $\mathbf{x}$ & & & & $x$ & & & \\
\hline $60-61$ & & 8 & $x$ & & $\mathbf{x}$ & $\mathbf{x}$ & $\mathbf{x}$ & & & $20-30^{\circ}$, BP. open \\
\hline $62-67$ & & 4 & $x$ & $\mathbf{x}$ & $\mathbf{x}$ & $\mathbf{x}$ & $x$ & $x$ & $\mathbf{x}$ & $20-30^{\circ}$. BP, open \\
\hline $63-64$ & & & $\mathbf{x}$ & & & B & & & $\mathbf{x}$ & \\
\hline$\infty 6-68$ & & & & & & B & $\mathbf{x}$ & $x$ & & \\
\hline
\end{tabular}

num 
Table A.1 (continued)

\begin{tabular}{|c|c|c|c|c|c|c|c|c|c|c|c|}
\hline $\begin{array}{l}\text { Depeh BGS } \\
\text { (f) }\end{array}$ & $\begin{array}{l}\text { Goologic } \\
\text { unit }\end{array}$ & $\begin{array}{l}\text { Fracturea } \\
\text { per fool }\end{array}$ & BHTV & VDI. & Caliper & Tempernture & $\begin{array}{c}\text { Deha } \\
\text { temperalure }\end{array}$ & $\begin{array}{c}\text { Deviation } \\
\text { survey }\end{array}$ & $\mathbf{S P}$ & Comments & \\
\hline $70-7$ & & & & & & $\mathbf{X}$ & $\mathbf{x}$ & & & & \\
\hline 75.76 & & & & & & B & $\mathbf{x}$ & & & & \\
\hline $78-79$ & & & & & & $\mathbf{B}$ & $\mathbf{x}$ & & & & \\
\hline $80-81$ & & & $\mathbf{x}$ & & $\mathbf{x}$ & $\mathbf{x}$ & $\mathbf{x}$ & $\mathbf{x}$ & & & \\
\hline $85-86$ & & & & & & B & $\mathbf{x}$ & & & & \\
\hline $87-88$ & & & $\mathbf{x}$ & $\mathbf{x}$ & & $\mathbf{x}$ & & & $\mathbf{x}$ & & \\
\hline $88-89$ & & & & & & & $\mathbf{x}$ & & & & \\
\hline $91-92$ & & & & & $\mathbf{x}$ & $\mathbf{x}$ & $\mathbf{x}$ & & & & \\
\hline $94-95$ & & 2 & & & & $\mathbf{x}$ & & & & $35^{\circ}$, BP, tight & \\
\hline $95-96$ & & 3 & & $\mathbf{s}$ & & & & $\mathbf{x}$ & & $20-35^{\circ}$, BP, light & \\
\hline $96-97$ & & 4 & $\mathbf{x}$ & $\mathbf{x}$ & $\mathbf{x}$ & $\mathbf{x}$ & $\mathbf{x}$ & & & $40^{\circ}$, EP, tight & \\
\hline $97-98$ & & & $\mathbf{s}$ & & & & & & & & \\
\hline $98-49$ & & 5 & $\mathbf{x}$ & $\mathbf{x}$ & & B & $\mathbf{x}$ & & & BP, light & 2 \\
\hline $99-100$ & & 3 & $\mathbf{x}$ & $\mathbf{x}$ & $\mathbf{x}$ & & $\mathbf{x}$ & & $\mathbf{x}$ & $20-40^{\circ}$, BP, tight & 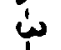 \\
\hline $100-101$ & & 2 & & & & & & & & $20^{\circ}$, BP, tight & $\dot{\omega}$ \\
\hline $101-102$ & & 2 & & & & & & & & $15-30^{\circ}$, BP, tight & \\
\hline $105-106$ & & 3 & $\mathbf{x}$ & & $\mathbf{x}$ & & & & & $40^{\circ}$, BP, light & \\
\hline $118-119$ & & 2 & $x$ & & & & & $\mathbf{x}$ & & & \\
\hline $120-121$ & & & $\mathbf{x}$ & & & $\mathbf{x}$ & & & & $30^{\circ}$, BP, tight & \\
\hline $123-125$ & & & $\mathbf{x}$ & $\mathbf{x}$ & $x$ & $\mathbf{x}$ & & & $\mathbf{x}$ & & \\
\hline $129-130$ & & 2 & & & & B & & & & $30^{\circ}$, BP, al. open to open & \\
\hline $131-132$ & & & $\mathbf{x}$ & & & B & $\mathbf{x}$ & & $\mathbf{x}$ & & \\
\hline $132-133$ & & 2 & $\mathbf{x}$ & $\mathbf{x}$ & & B & $\mathbf{x}$ & & $\mathbf{x}$ & $20.30^{\circ}$, AP, sl. open & \\
\hline $134-135$ & & 2 & $\mathbf{x}$ & $\mathbf{x}$ & & & & & & $30^{\circ}$, BP, sl. open to open & \\
\hline $136-137$ & & 2 & $\mathbf{x}$ & $\mathbf{x}$ & & & & & & $30^{\circ}$, BP, tight to sl. open & \\
\hline $138-139$ & & 2 & & $\mathbf{s}$ & & & & & & $35^{\circ}$. BP. tight to sl. upen & \\
\hline $139-140$ & & & $\mathbf{S}$ & & & & & & & & \\
\hline $143-144$ & & 3 & & & & & & $\mathbf{x}$ & & $35^{\circ}$, BP. sl. open & \\
\hline $146-147$ & & & $\mathbf{x}$ & & $\mathbf{x}$ & $\mathbf{x}$ & & & & & \\
\hline $147-148$ & & 2 & $\mathbf{x}$ & $\mathbf{x}$ & & B & $x$ & & & $30-40^{\circ}$, BP, s1. open to open & \\
\hline $149-150$ & & 3 & $\mathbf{x}$ & & & & & & & $30^{\circ}$, BP, tight to sl. open & \\
\hline
\end{tabular}


Table A3.1 (continued)

\begin{tabular}{|c|c|c|c|c|c|c|c|c|c|c|}
\hline $\begin{array}{l}\text { Depth BGS } \\
\text { (it) }\end{array}$ & $\begin{array}{l}\text { Goologic } \\
\text { unit }\end{array}$ & $\begin{array}{l}\text { Fractures } \\
\text { per foot }\end{array}$ & BHTV & VDL & Caliper & Temperature & $\begin{array}{c}\text { Deha } \\
\text { temperature }\end{array}$ & $\begin{array}{c}\text { Deviation } \\
\text { survey }\end{array}$ & SP & Comments \\
\hline $150-151$ & & 2 & $\mathbf{x}$ & & & $\mathbf{x}$ & $\mathrm{x}$ & & & $30^{\circ}$, BP, al. ogen \\
\hline $152-153$ & & & $\mathbf{x}$ & & $\mathbf{x}$ & & $\mathbf{s}$ & & & \\
\hline $153-154$ & & 2 & $\mathbf{x}$ & & & & & & & $40^{\circ}$, BP, tight to sl. open \\
\hline $155-156$ & & & $\mathbf{x}$ & & $\mathrm{x}$ & & $\mathbf{x}$ & & & \\
\hline $158-159$ & & & $\mathbf{x}$ & & & & $\mathbf{x}$ & & & \\
\hline $159-160$ & & 2 & & & $\mathbf{x}$ & & & & & $20-25^{\circ}$, BP, al. open to open \\
\hline $160-161$ & & & $\mathbf{x}$ & & & & $\mathbf{x}$ & & & \\
\hline $170-171$ & & 2 & $\mathbf{x}$ & & $\mathbf{x}$ & & & & & $30-40^{\circ}$, BP, tight to open \\
\hline $176-17$ & & 2 & & & & & & $\mathbf{x}$ & & $20^{\circ}$, BP, tight to open \\
\hline $179-180$ & & 2 & $\mathbf{x}$ & $\mathbf{x}$ & & & & & & $30^{\circ}$. BP, tight \\
\hline $180-181$ & & 5 & $\mathbf{x}$ & $\mathbf{x}$ & & & & & $\mathbf{x}$ & $35^{\circ}$, BP, open \\
\hline $181-182$ & & 2 & & $\mathbf{x}$ & & & & & & $30^{\circ}$, BP, tight \\
\hline $182-183$ & & 3 & & & & & $\mathbf{x}$ & $\mathbf{x}$ & & $30^{\circ}$, BP, open \\
\hline$i 84-185$ & & & $\mathbf{x}$ & & $\mathbf{x}$ & & & & & \\
\hline $185-186$ & & $\mathbf{3}$ & & & & & & & & $30-40^{\circ}$, BP, light \\
\hline $187-188$ & & & $\mathbf{x}$ & & & & & & & \\
\hline $190-191$ & & & & & & B & & & $\mathbf{x}$ & \\
\hline $195-196$ & & & $\mathbf{x}$ & & $\mathbf{x}$ & & $\mathbf{x}$ & & & \\
\hline 197.198 & & 2 & $\mathbf{x}$ & $\mathbf{s}$ & & & $\mathbf{x}$ & $\mathbf{x}$ & & $30^{\circ}$, BP, sl. open to open \\
\hline $207-208$ & & & $\mathbf{x}$ & & $\mathbf{x}$ & & $x$ & & & \\
\hline 211.212 & & 2 & & $s$ & & B & $\mathbf{x}$ & $\mathbf{x}$ & $\mathbf{x}$ & $35^{\circ}$, BP, tight and open \\
\hline $212-213$ & & & & $\mathbf{x}$ & $\mathbf{x}$ & & & & & \\
\hline $213-214$ & & & $\mathbf{x}$ & & & & & & & \\
\hline $218-219$ & & 2 & $x$ & $\mathbf{x}$ & $\mathbf{x}$ & & & & & 30'. BP, tight and open \\
\hline $219-220$ & & 3 & $\mathbf{x}$ & $\mathbf{x}$ & $\mathbf{x}$ & & & & & $20-30^{\circ}$, BP, light to open \\
\hline $220-221$ & & 2 & & & & & & & & $30^{\circ}$, BP, open \\
\hline $221-222$ & & 2 & $x$ & & & & & & & $25-30^{\circ}$, BP, s1. ope.t to open \\
\hline $222-223$ & & 3 & $\mathbf{x}$ & & & & & & & $30^{\circ}$, BP, open to tight \\
\hline 223224 & & 3 & $x$ & & & $x$ & & & $\mathbf{x}$ & $30^{\circ}$, BP, open; $60^{\circ}$, th to bedding, tight \\
\hline $224-225$ & & 5 & $\mathrm{x}$ & $\mathbf{x}$ & & & & $\mathrm{x}$ & & 30, BP, open \\
\hline $225-226$ & & & $\mathrm{x}$ & & & & & & & \\
\hline rmeos & & & & & & & & & & \\
\hline
\end{tabular}


Table A3.1 (continued)

\begin{tabular}{|c|c|c|c|c|c|c|c|c|c|c|c|}
\hline $\begin{array}{l}\text { Depth BGS } \\
\text { (A) }\end{array}$ & $\begin{array}{l}\text { Gooblogic } \\
\text { unit }\end{array}$ & $\begin{array}{l}\text { Fracturea } \\
\text { per foot }\end{array}$ & BHTV & VDI, & Caliper & Tempenture & $\begin{array}{c}\text { Delta } \\
\text { temperature }\end{array}$ & $\begin{array}{l}\text { Deviation } \\
\text { survey }\end{array}$ & $\mathbf{S P}$ & Comments & \\
\hline $226-227$ & & 4 & $\mathbf{x}$ & $\bar{x}$ & & & & & & $20-30^{\circ}, \mathrm{BP}$, open & \\
\hline $227-228$ & & & $\mathbf{x}$ & & & & & & & & \\
\hline $229-230$ & & & $\mathbf{x}$ & & & & & & & & \\
\hline $230-231$ & & 2 & $\mathbf{x}$ & s & & & & & & S-25', BP, tight & \\
\hline 231-232 & & 2 & $\mathbf{x}$ & & & & & & & $30-40^{\circ}$, BP, open & \\
\hline $232-233$ & & 5 & $\mathbf{x}$ & & & & & & & $20-25^{\circ}$, BP, 4 open, 1 tight & \\
\hline $233-234$ & & 2 & $\mathbf{x}$ & $\mathbf{x}$ & $x$ & & & & & $10-40^{\circ}$, BP, tight and open & \\
\hline $234-235$ & & 2 & $\mathbf{x}$ & & & & & & & $30-60^{\circ}$. BP, tighe and open & \\
\hline $237-238$ & & 2 & $\mathbf{x}$ & & & $\mathbf{x}$ & & $\mathbf{x}$ & & $30^{\circ}$, BP, sl. open to open & \\
\hline $239-240$ & & 2 & $\mathbf{x}$ & & & & & & & $25^{\circ}$. BP, tight to al. open & \\
\hline $246-247$ & & & $\mathbf{x}$ & & & & & & & & \\
\hline $248-249$ & & 2 & & $\mathbf{s}$ & & & & & & $25-30^{\circ}$, BP, tight to sl. open & \\
\hline $249-250$ & & & $\mathbf{s}$ & & & & & & & & 2 \\
\hline $251-252$ & & 3 & $\mathbf{x}$ & & & & & $\mathbf{x}$ & & 25-30', BP, open & نٌّ \\
\hline $253-254$ & & & & $\mathbf{x}$ & & & & & & & \\
\hline 258-259 & & 2 & $\mathbf{x}$ & & & & & & & $30^{\circ}$, BP, light and open & \\
\hline $259-260$ & & 2 & $\mathbf{x}$ & $\mathbf{x}$ & & & & $\mathbf{x}$ & & $25-30^{\circ}$, BP, sl. open to open & \\
\hline $260-261$ & & & $\mathbf{x}$ & & & & & & & & \\
\hline $262-263$ & & & $\mathbf{x}$ & & & & & & & & \\
\hline $270-271$ & & 4 & $\mathbf{x}$ & & & & & & & $25-30^{\circ}$, BP, tight to open & \\
\hline $275-276$ & & 2 & $\mathbf{x}$ & & & & & & & $20-25^{\circ}$. BP, tight & \\
\hline $277-278$ & & & $\mathbf{s}$ & & & & & & & & \\
\hline $282-283$ & & & & $\mathbf{s}$ & & B & & $\mathbf{x}$ & $\mathbf{x}$ & & \\
\hline $289-290$ & & & $\mathbf{x}$ & $\mathbf{x}$ & & & & $\mathbf{x}$ & & & \\
\hline $295-296$ & $\mathbf{F}$ & & & $x$ & & & & $\mathbf{x}$ & & & \\
\hline $307-308$ & & & $\mathbf{x}$ & & & & & & & & \\
\hline $311-312$ & & & & $\mathbf{x}$ & & & & $\mathbf{x}$ & & & \\
\hline 315-316 & & 2 & & & $\mathbf{x}$ & & & & & $30^{\circ}$, BP, tight & \\
\hline $317-318$ & & 3 & & $\mathbf{x}$ & & & & & & $20-30^{\circ}$, BP, tight & \\
\hline $318-319$ & & 2 & & $\mathbf{x}$ & & & & & & $25-30^{\circ}$, BP, tight to open & \\
\hline $319-320$ & & 2 & & & & & & & & $25-40^{\circ}$, BP, tight to open & \\
\hline
\end{tabular}


Table A3.1 (continued)

\begin{tabular}{|c|c|c|c|c|c|c|c|c|c|c|}
\hline $\begin{array}{l}\text { Depth BGS } \\
\text { (A) }\end{array}$ & $\begin{array}{c}\text { Geologic } \\
\text { unin }\end{array}$ & $\begin{array}{l}\text { Fracturea } \\
\text { per foot }\end{array}$ & BHTV & VDL & Caliper & Temperature & $\begin{array}{l}\text { Deha } \\
\text { temperature }\end{array}$ & $\begin{array}{l}\text { Deviation } \\
\text { survey }\end{array}$ & $\mathbf{S P}$ & Comments \\
\hline $320-321$ & & 2 & & & & & & $\mathbf{x}$ & & $20^{\circ}$, BP, tight \\
\hline 321-322 & & 2 & & & & & & & & $25-40^{\circ}$, BP, tight \\
\hline 322-323 & & & $\mathbf{x}$ & $\mathbf{x}$ & $\mathbf{x}$ & & & & & \\
\hline $325-326$ & & 2 & $\mathbf{x}$ & $\mathbf{x}$ & & & & $\mathbf{x}$ & & $25-40^{\circ}$, BP, open \\
\hline $329-330$ & $\mathbf{E}$ & 3 & & $\mathbf{x}$ & & & & $\mathbf{x}$ & & $30^{\circ}$, BP, tigthe \\
\hline $332-333$ & & 2 & & & & & & & & $30^{\prime}$, BP, al. open \\
\hline 333-334 & & & & $\mathbf{x}$ & $\mathbf{x}$ & B & & & $\mathbf{x}$ & \\
\hline $3.36-337$ & & 6 & $\mathbf{x}$ & $\mathbf{x}$ & & & & & & 30-45 , BP, open; $1 \perp$ to bodding, tight \\
\hline $337-338$ & & 3 & $\mathbf{x}$ & $\mathbf{x}$ & & & & & & $25-35^{\circ}$. BP, tight to open \\
\hline 338.339 & & 2 & & & & & & & & $25-30^{\circ}$, BP, fairly light to al. open \\
\hline $339-340$ & & 3 & $\mathbf{x}$ & & & & & $\mathbf{x}$ & & $\begin{array}{l}25.30^{\circ} \text {. BP, open and al. open: } 1 \perp \text { to hed ding. } \\
\text { i.ght }\end{array}$ \\
\hline $341-342$ & & & & $\mathbf{s}$ & & & & & & \\
\hline $343-344$ & & & $\mathbf{x}$ & $\mathbf{x}$ & & & & & & \\
\hline $345-346$ & & 2 & $\mathbf{x}$ & $\mathbf{x}$ & & & & & & $30 \%$ BP, open \\
\hline $346-347$ & & 2 & $\mathbf{x}$ & $\mathbf{x}$ & & & & & & $30-35^{\circ}$, BP, open \\
\hline $347-348$ & & & $\mathbf{x}$ & & & & & & & \\
\hline $348-349$ & & 2 & $\mathbf{x}$ & & & & & & & $20-25^{\circ}$, BP, almost tight \\
\hline $349-350$ & & 2 & $\mathbf{x}$ & $\mathbf{x}$ & & & & & & $15+30^{\circ}$, BP, tighi, open \\
\hline $35 c-351$ & & & $\mathbf{x}$ & $\mathbf{s}$ & & & & & & \\
\hline $351-352$ & & 2 & & $\mathbf{x}$ & & & & & & $30^{\circ}$, BP, open \\
\hline $352-353$ & & 3 & & $\mathbf{x}$ & & & & & & $20-30^{\circ}$, BP, open \\
\hline $353-354$ & & 2 & $\mathbf{x}$ & $\mathbf{x}$ & $\mathbf{x}$ & & & $\mathbf{x}$ & & $25-30^{\circ}$, BP, open \\
\hline $354-355$ & & & $\mathbf{x}$ & & & & & & & \\
\hline $355-356$ & & 3 & & $\mathbf{x}$ & & & & & & $30^{\circ}$, BP, sh open to open \\
\hline $356-357$ & & 2 & & & & & & & & $20.25 '$, BP, open \\
\hline $357-358$ & & 2 & & $\mathbf{x}$ & & & & & & 30-35. BP, open \\
\hline $359-360$ & & 2 & $\mathbf{x}$ & $\mathbf{x}$ & & & & & & 25-30', BP, open \\
\hline $360-361$ & & 3 & & $\mathbf{x}$ & & & & & & $20-35^{\circ}$, BP, open to tight \\
\hline $365-366$ & & & $s$ & & & & & & & \\
\hline $366-367$ & & & & $\mathbf{x}$ & & & & & & \\
\hline
\end{tabular}


Tative A3.1 (comtinwed)

\begin{tabular}{|c|c|c|c|c|c|c|c|c|c|c|}
\hline $\begin{array}{l}\text { Depth BGS } \\
\text { (A) }\end{array}$ & $\begin{array}{c}\text { Geobgic } \\
\text { unir }\end{array}$ & $\begin{array}{l}\text { Frectures } \\
\text { per foot }\end{array}$ & BHTV & VDL & Caliper & Tempenture & $\begin{array}{c}\text { Delin } \\
\text { lemperature }\end{array}$ & $\begin{array}{l}\text { Deviation } \\
\text { aurvey }\end{array}$ & $\mathbf{S P}$ & Commente \\
\hline $369-370$ & & & & $\mathbf{x}$ & & & & & & \\
\hline 383-384 & & & & $\mathbf{x}$ & $\mathbf{x}$ & & & $\mathbf{x}$ & & \\
\hline $389-390$ & & 2 & $\mathbf{x}$ & & & $\mathbf{B}$ & $\mathbf{x}$ & & & $\perp$ to bedding; $30^{\circ}$, BP, opea \\
\hline $394-395$ & & & & $\mathbf{x}$ & & & & & & \\
\hline 395.396 & & 3 & +++ & $\mathbf{x}$ & & & & & & $\perp$ to bodding; partially healod; $30^{\circ}$, BP. opea \\
\hline
\end{tabular}

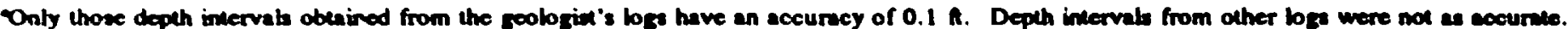

From goulogiti's bs.

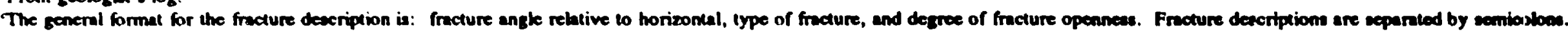

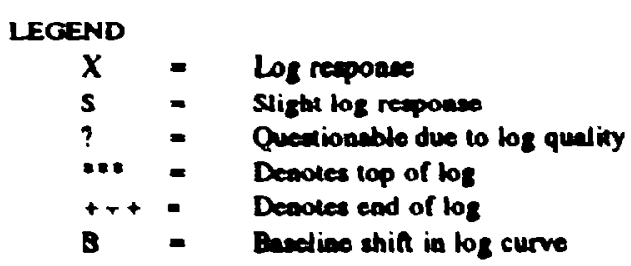

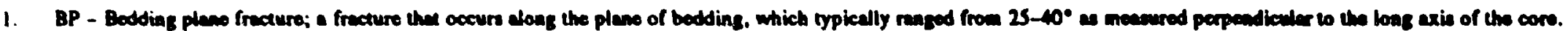

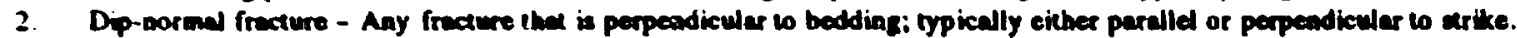

3. Dip-paralled frecture - Aay fracture that is paralled to beddine.

4. Low angle frecture - As measured perpendiculer to the long exia of the core, a low anglo frecture is geanerally at an angle leas than bedding.

5. High angle fracture - As moasund perpendicular to twe loag exis of the core, a high angle frecture is canerally a ca engle greater than beddiag.

6. $L$ - A dip-normal frecture; perpeadicular to bodding. 


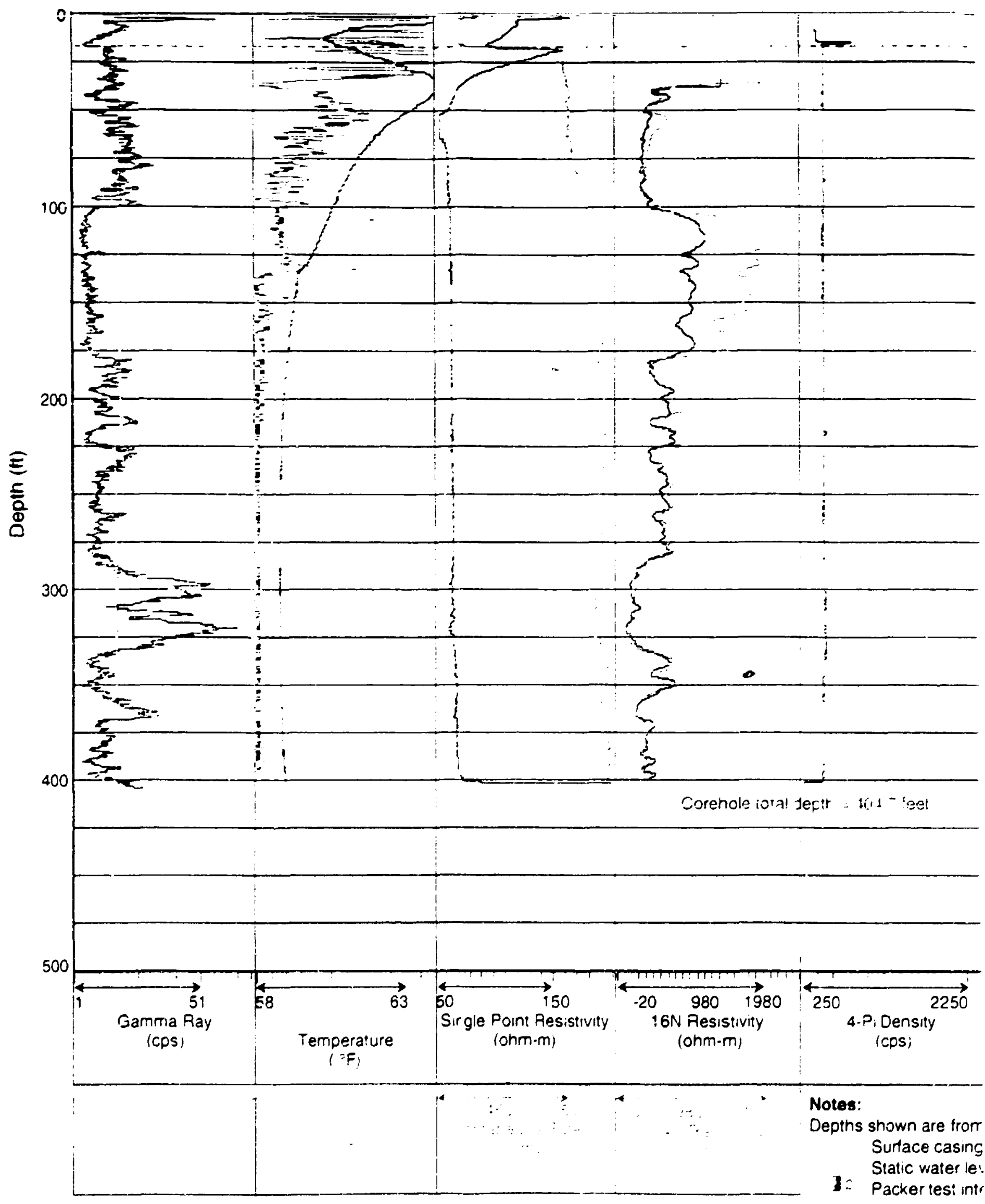




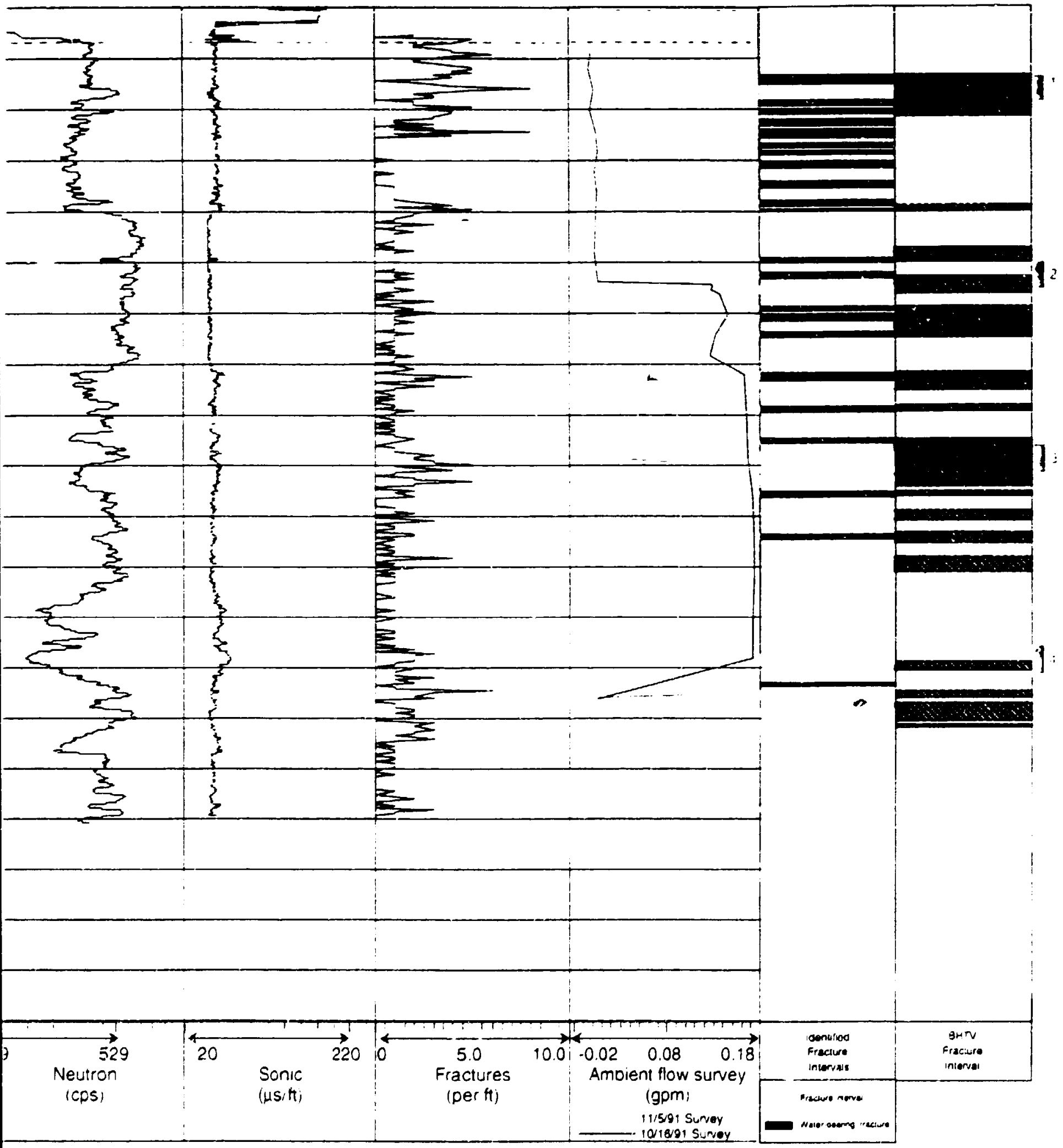

round surface

epth $=17 \mathrm{~h}$

at time of logging $=0.92 \mathrm{ft}$

al

Fig. A3.1. CH009 borehole geophysical lings. 

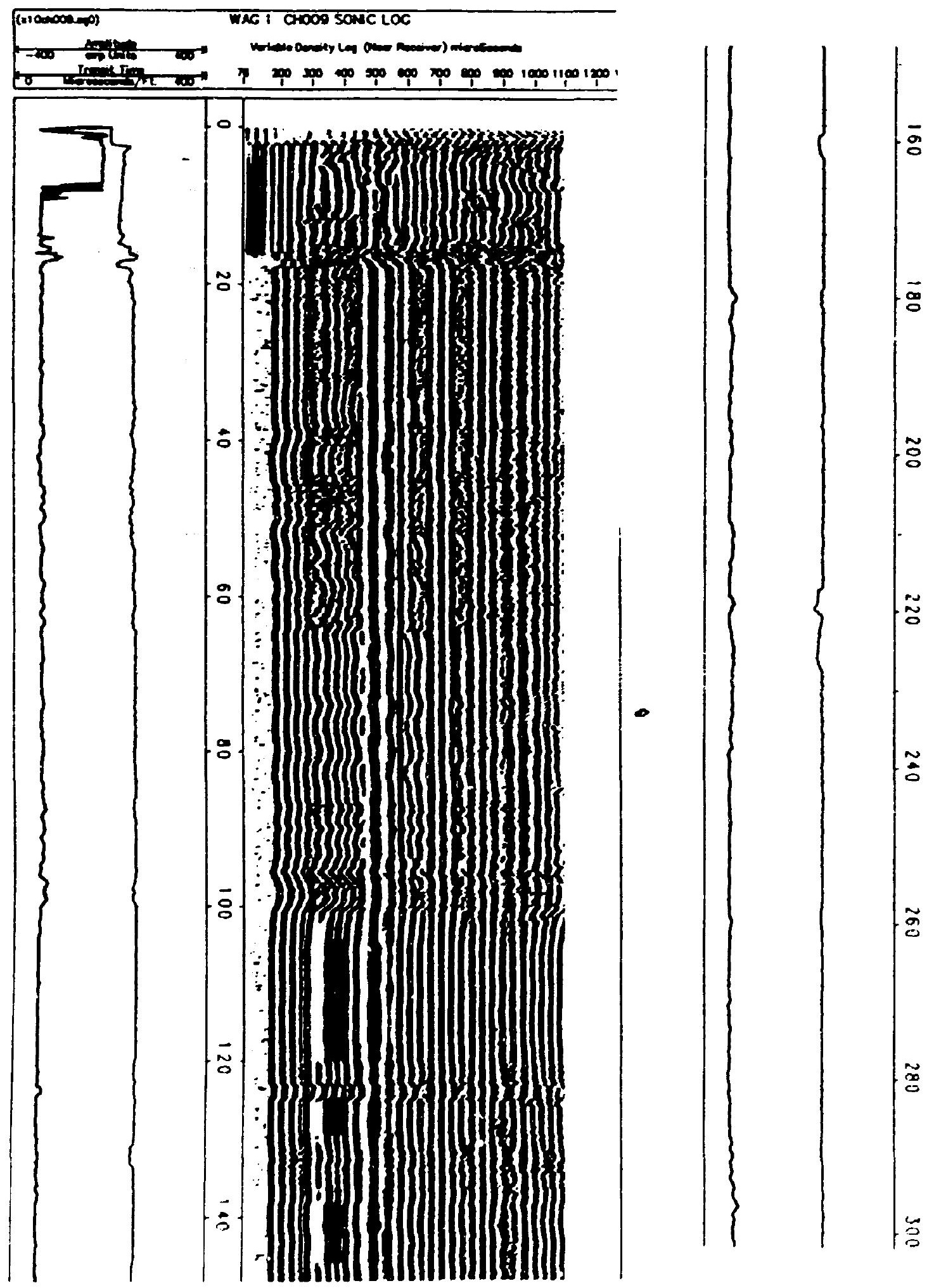


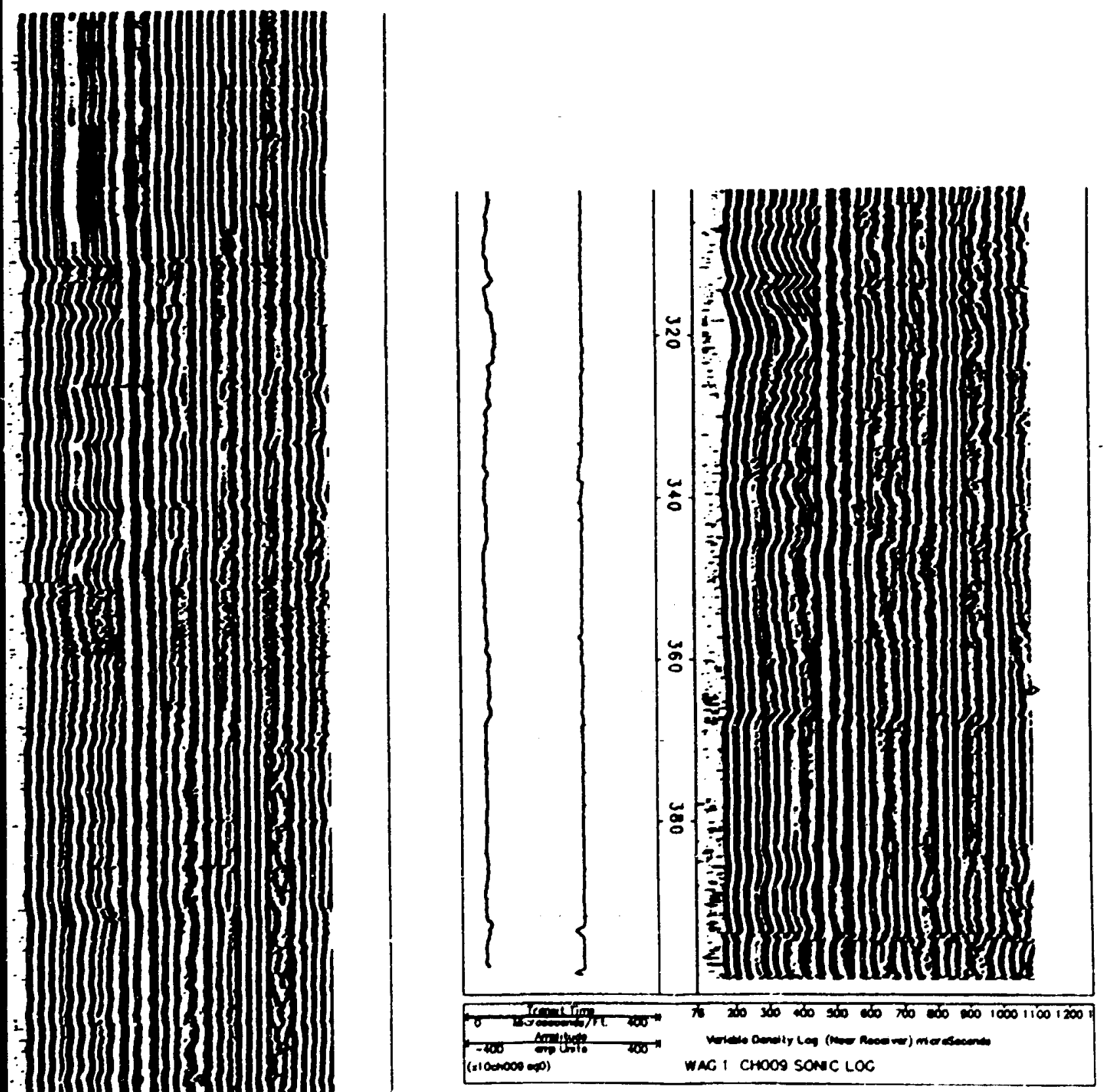

Fig. A3.2. CHOO9 variable density (acoustic) log. 
A-3-10

8
8
0
0
0
$\frac{1}{5}$
0
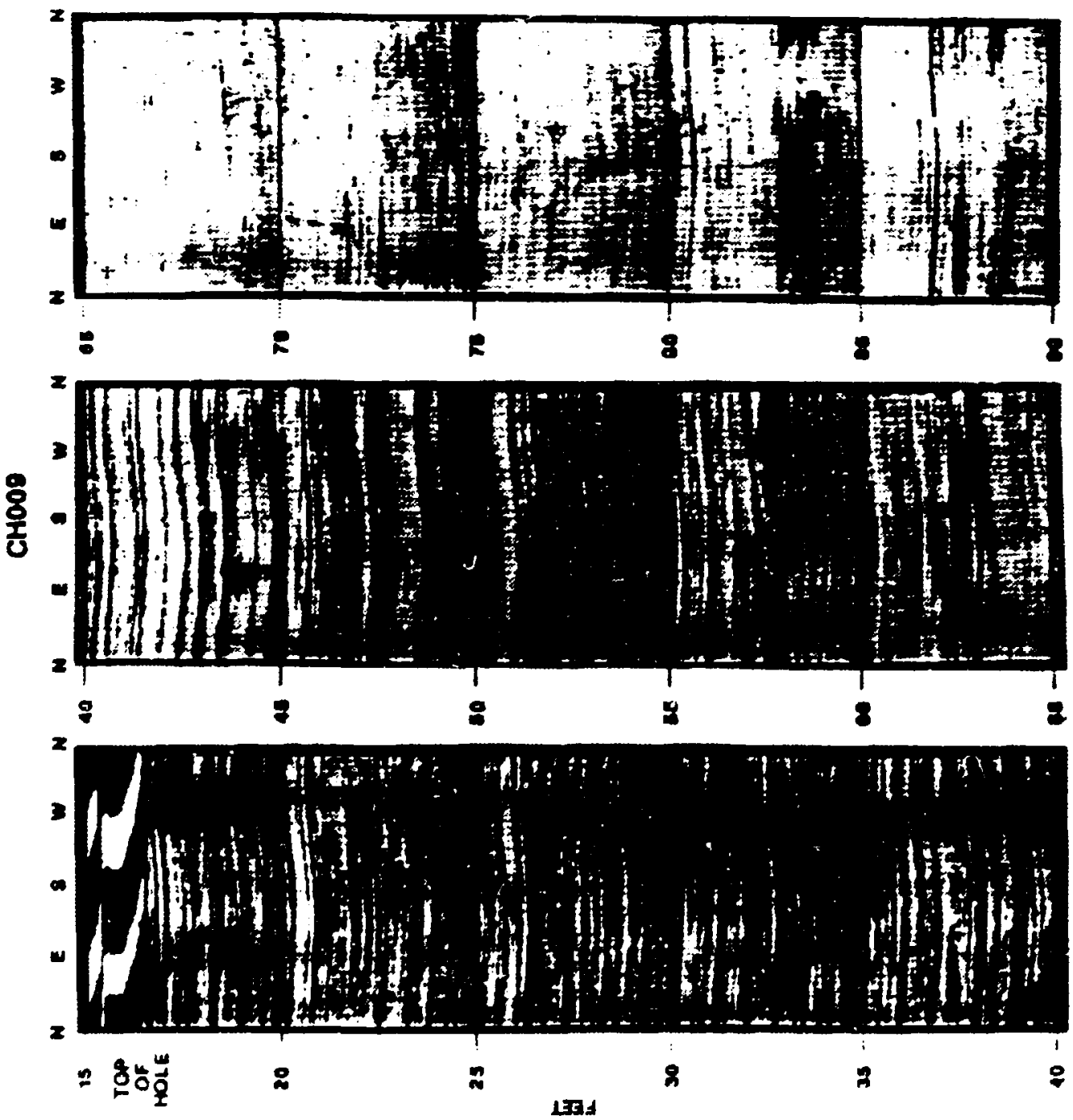
8
8
0
0
$\vdots$
0
$\frac{1}{2}$
0
0
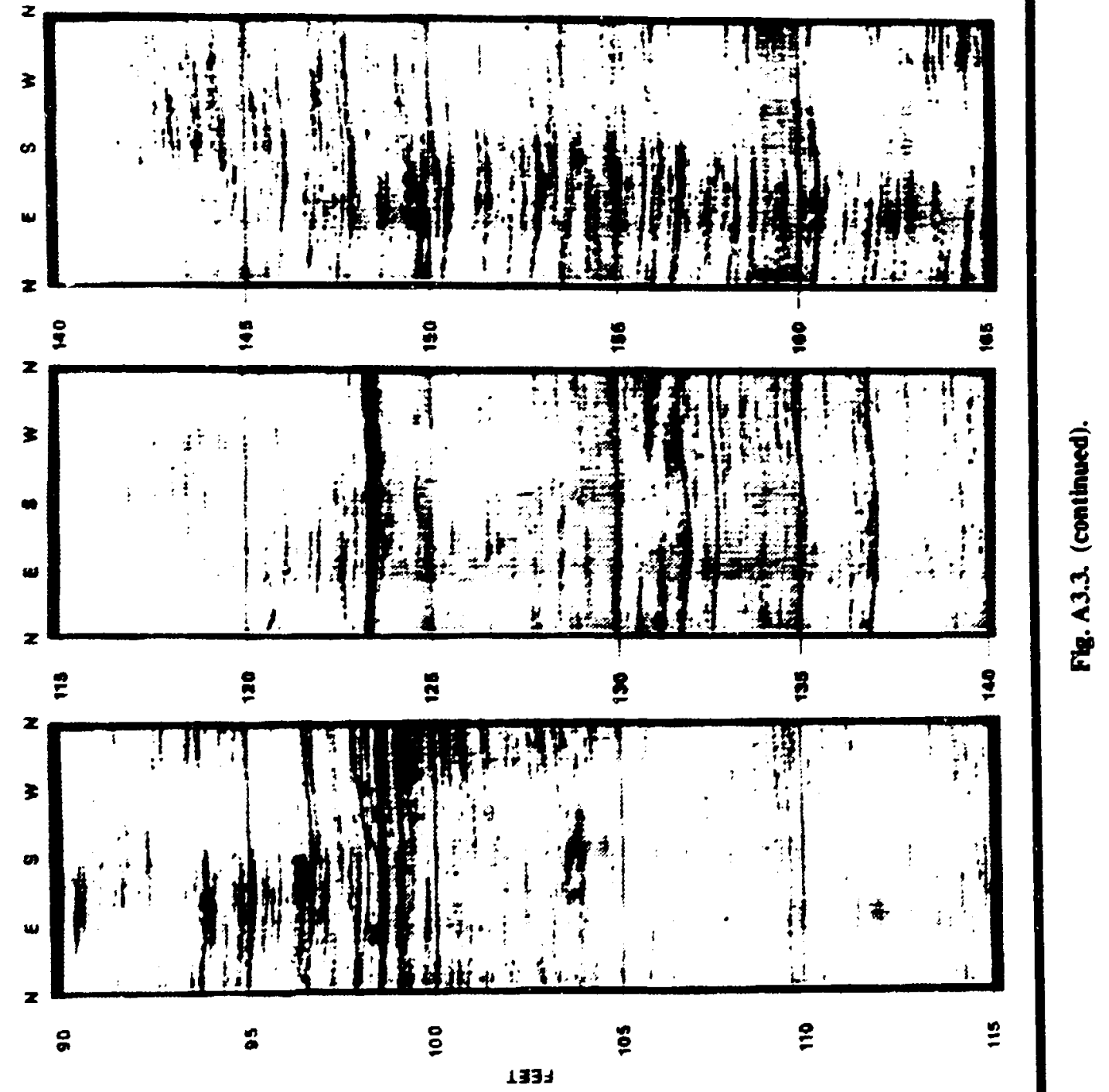


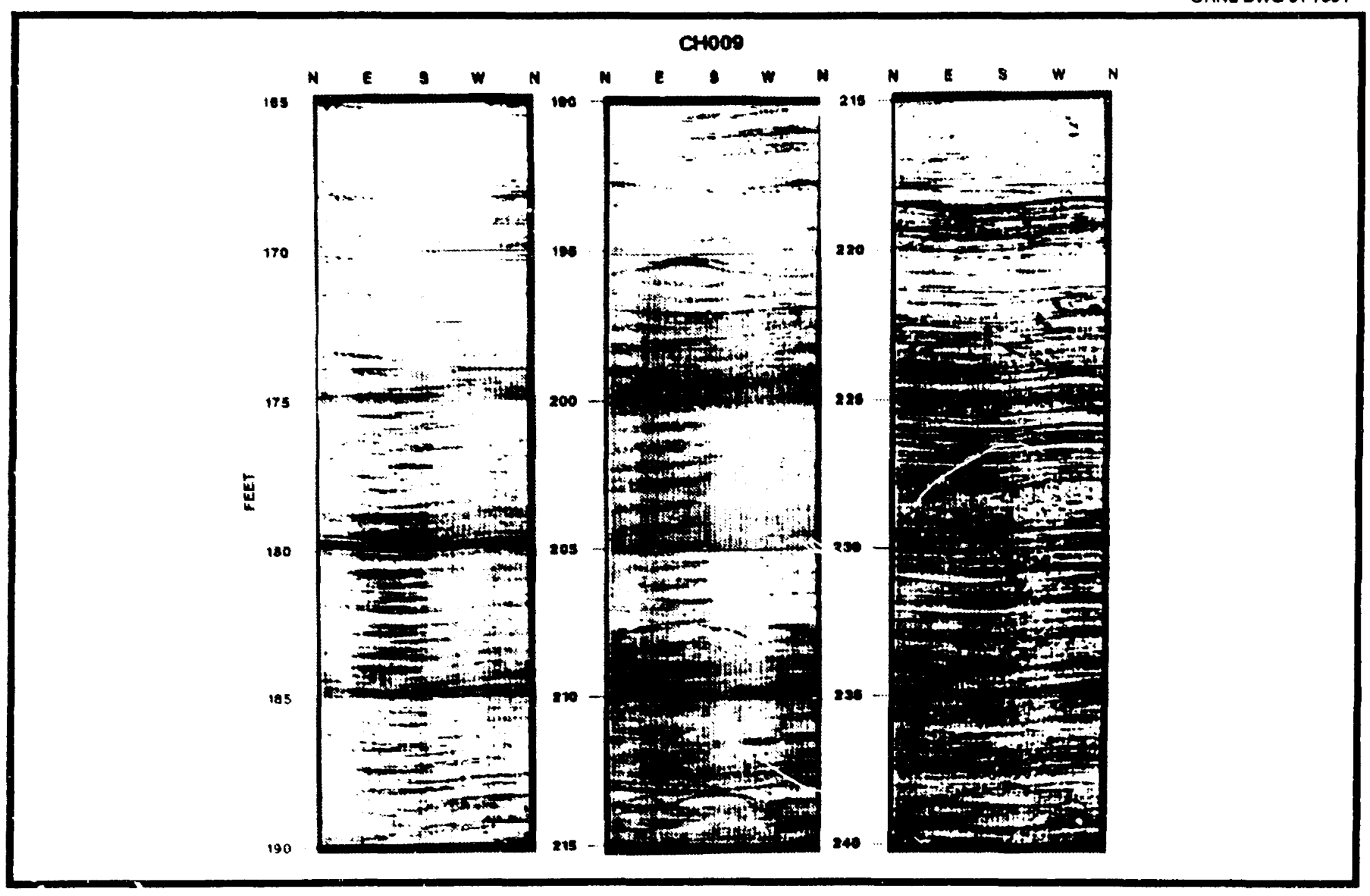

Fig. A3.3. (coatinued). 


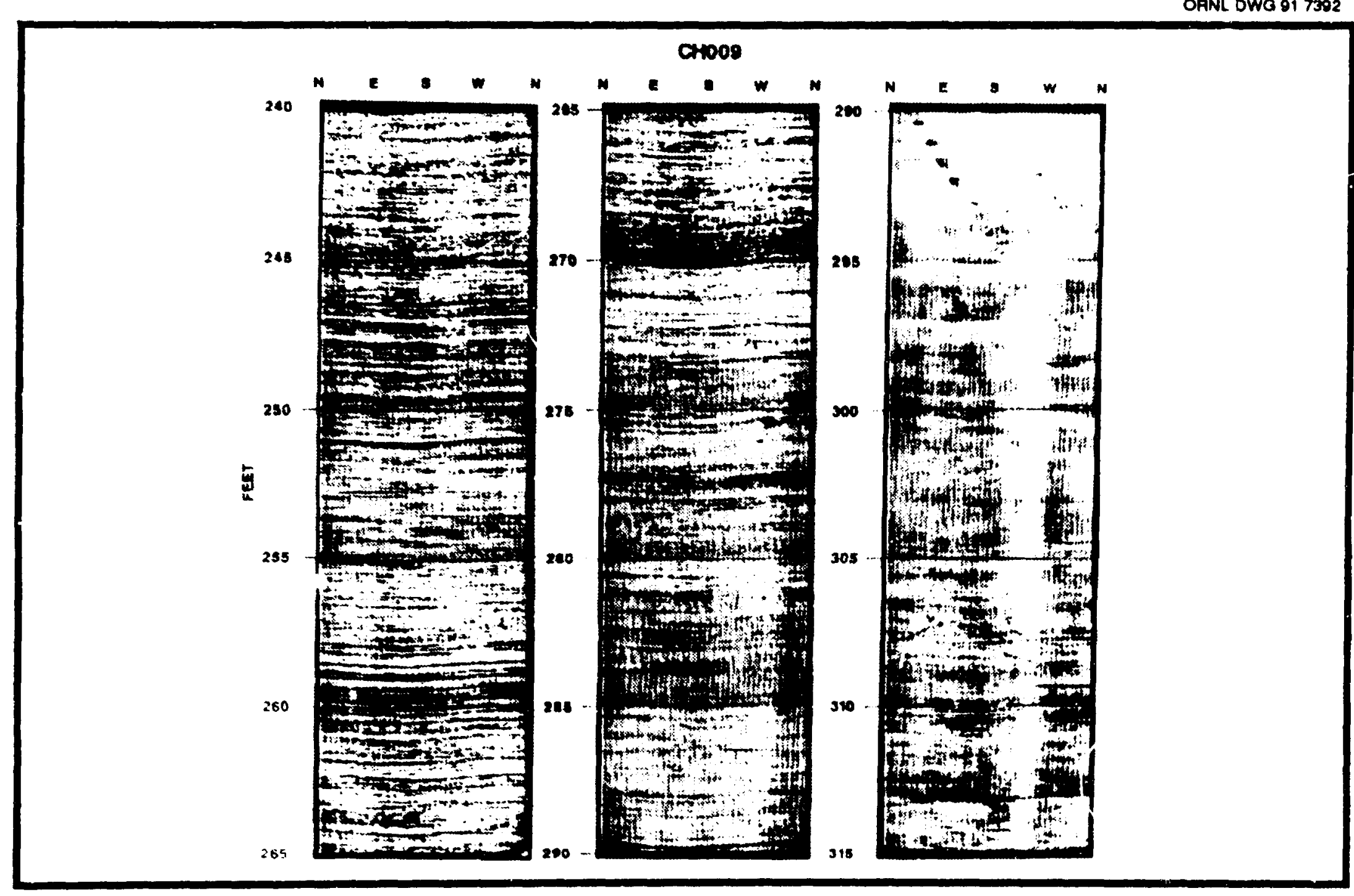

Fig. A3.3. (contlnued). 


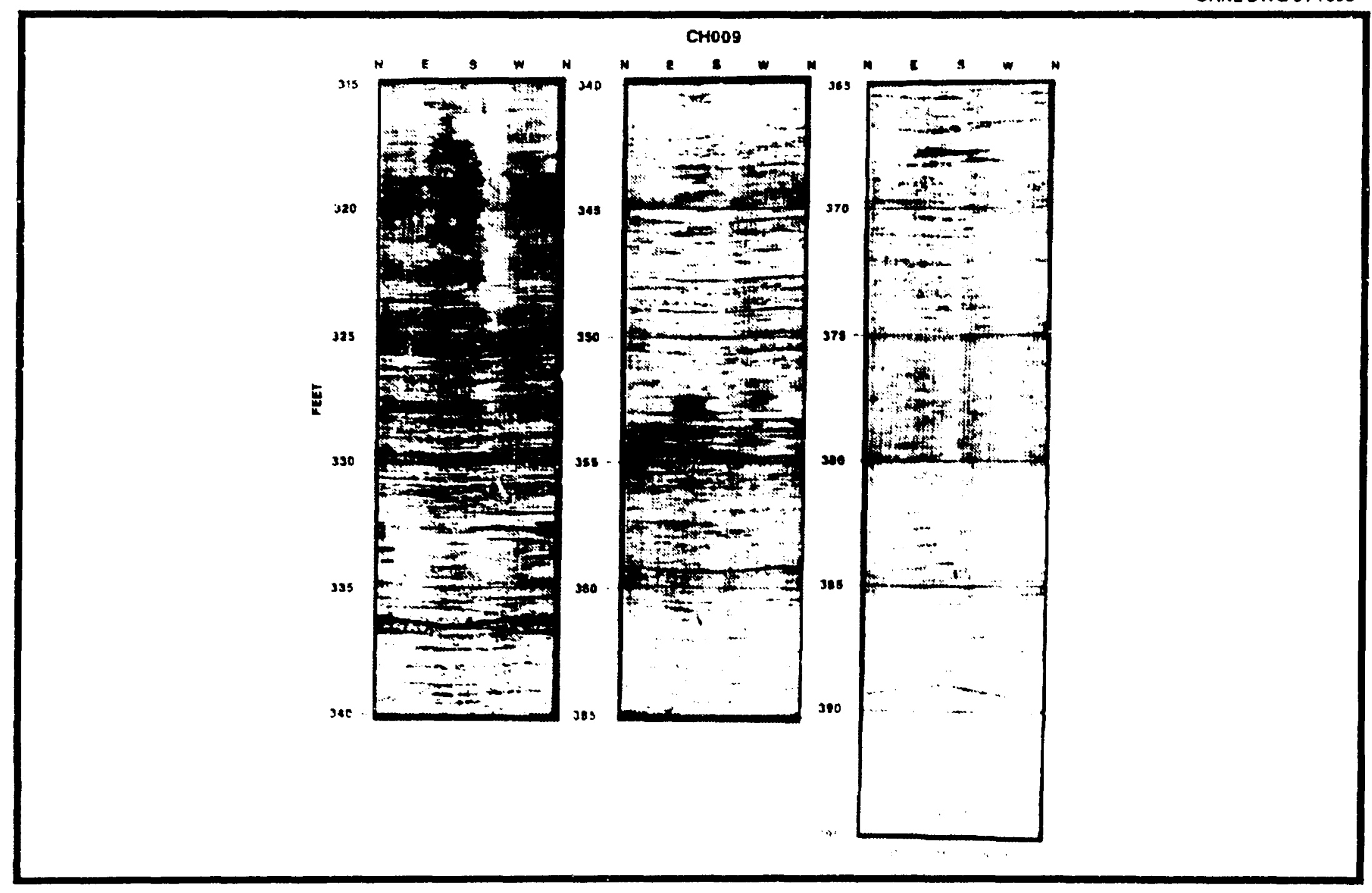




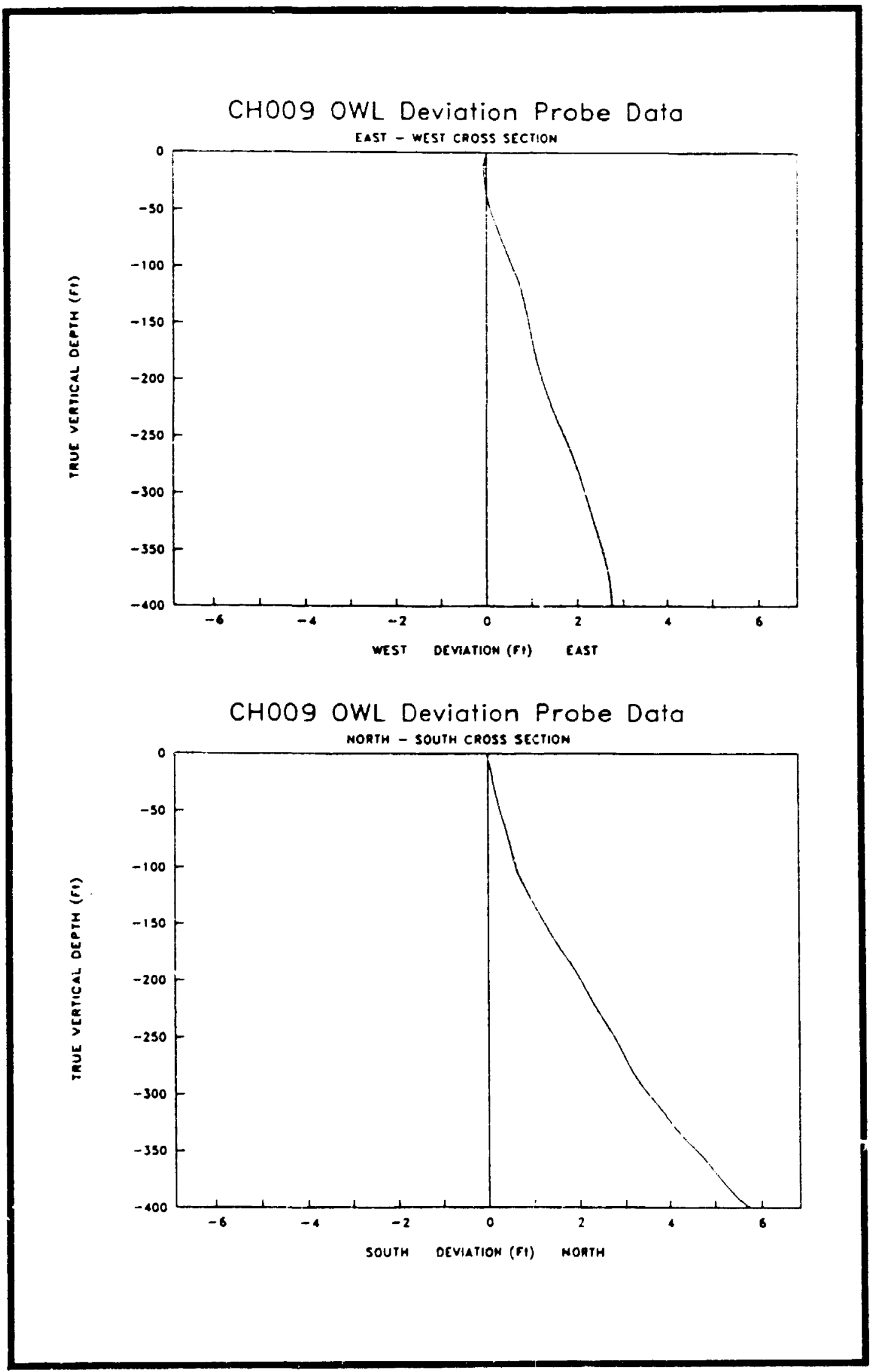

Fig. A3.4. CH009 OWL deviation probe data. 


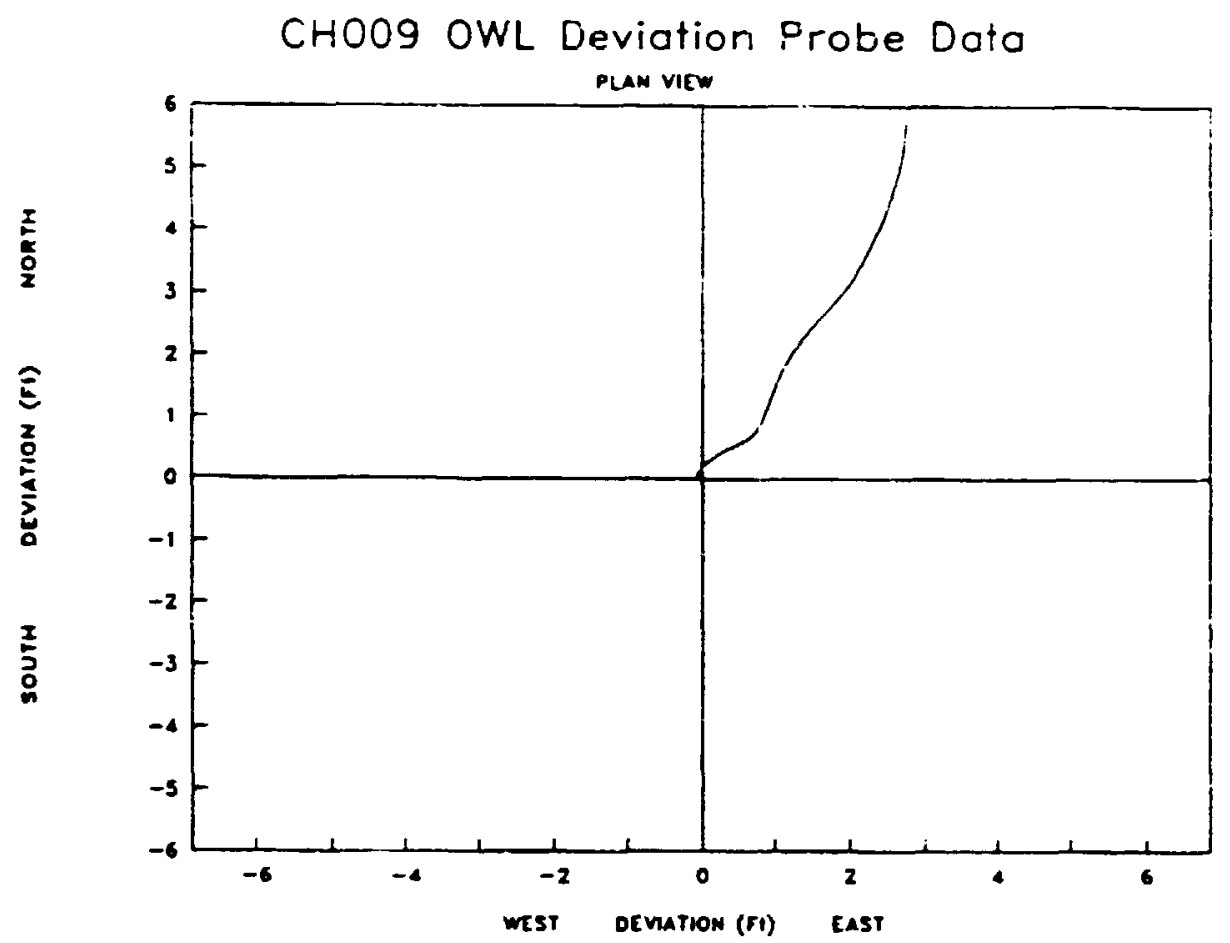

CHOO9 OWL Deviation Probe Data

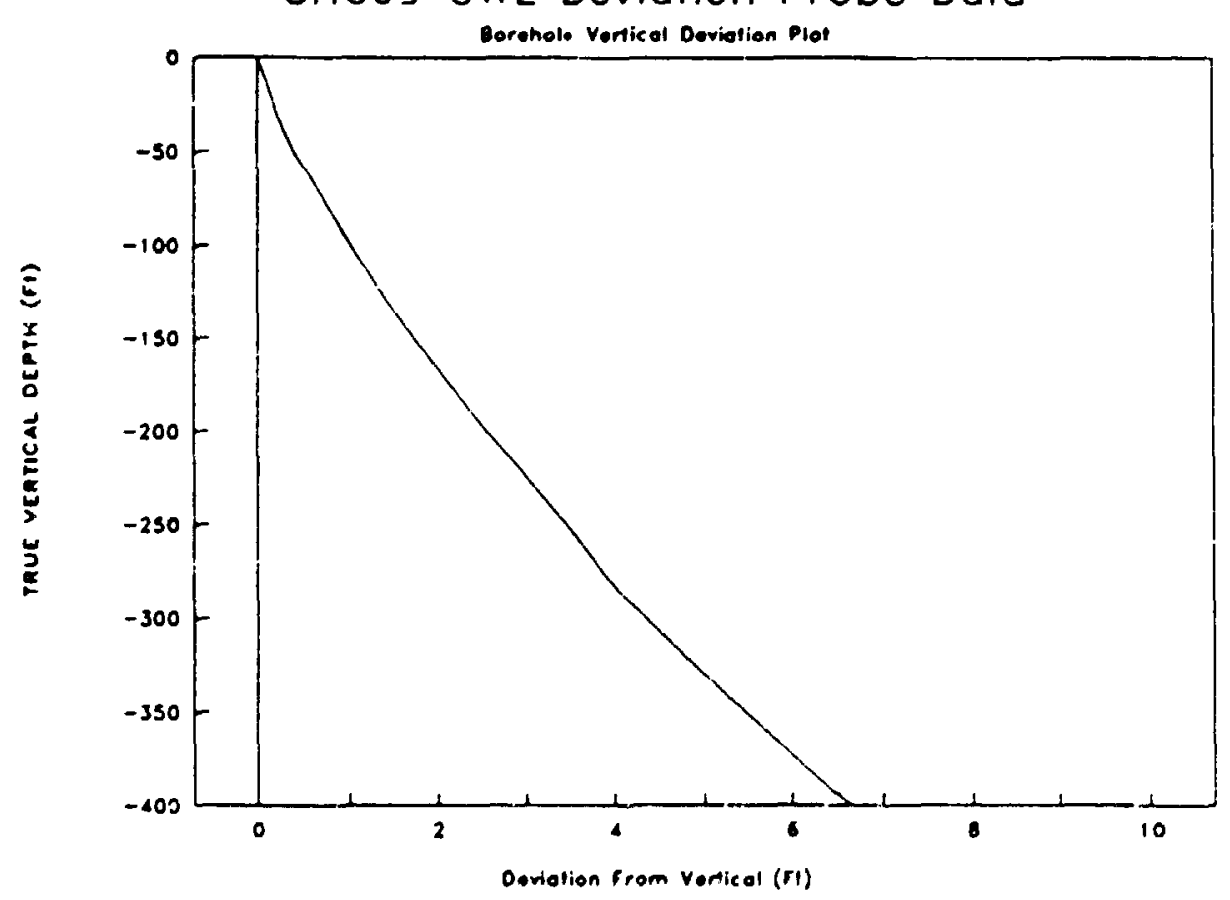

Fig. A.3.4. (rontinued). 


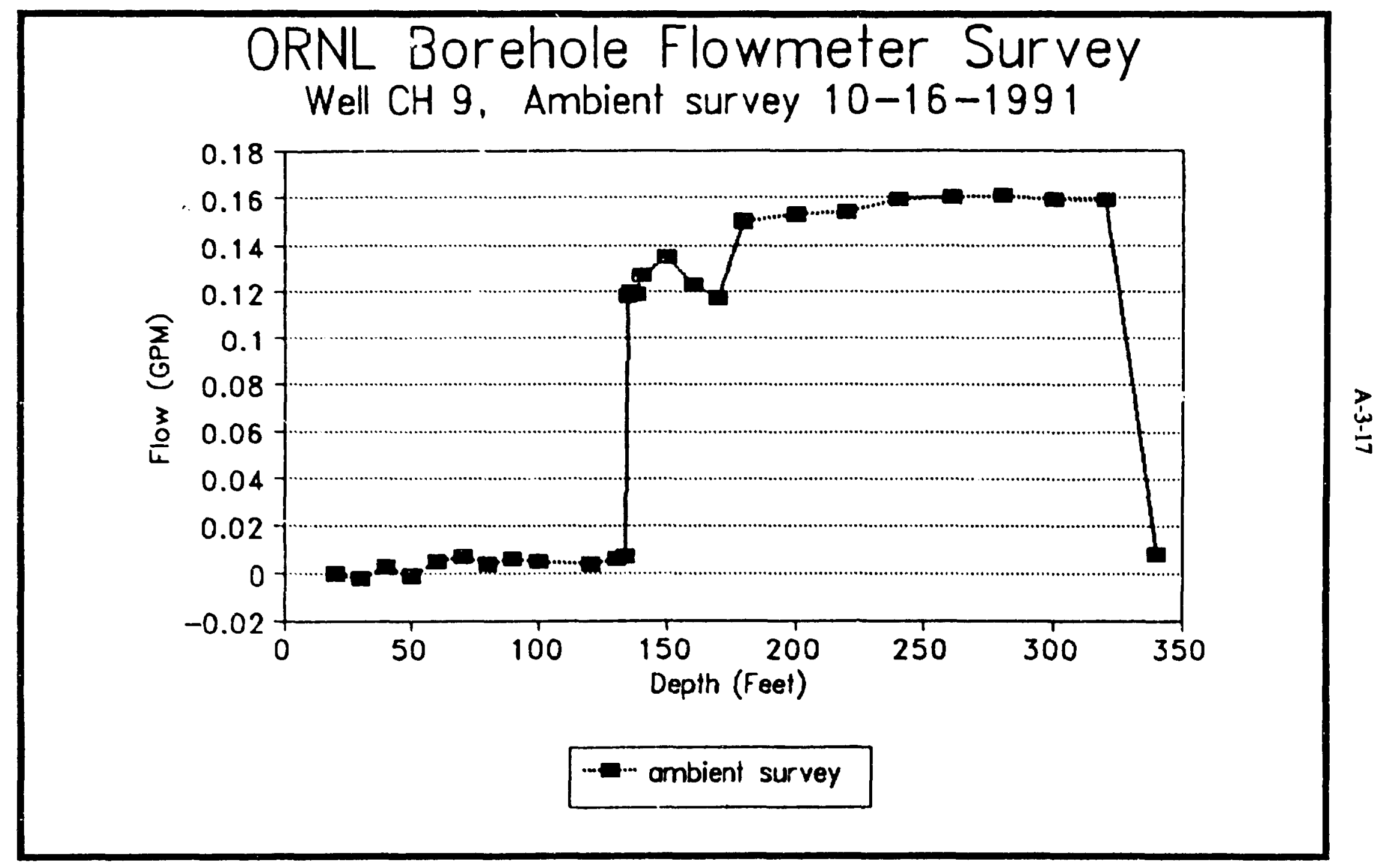

Fig. A3.5. CH(09 ORNL borehole nowmeter survey. 


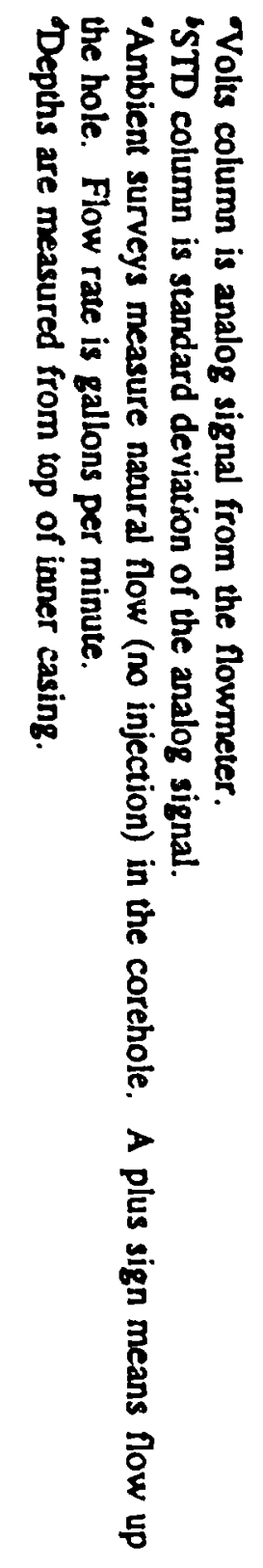

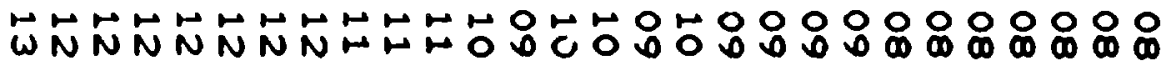

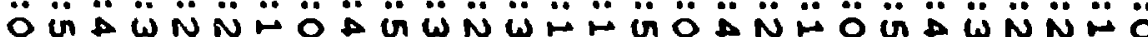
a V

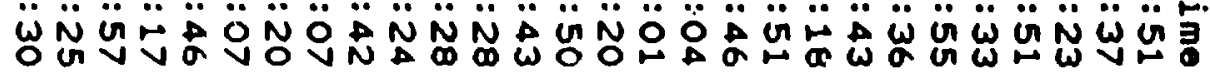

O $000000000001000000000000005 \pi$

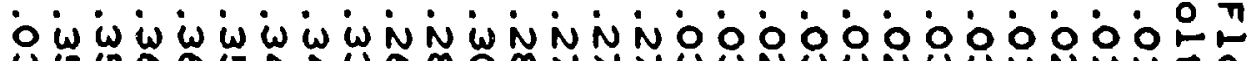

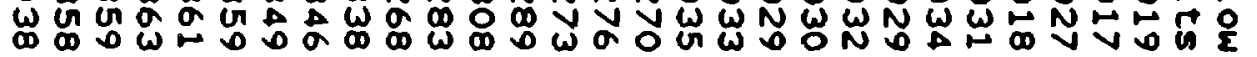

0000000000000000000000000000

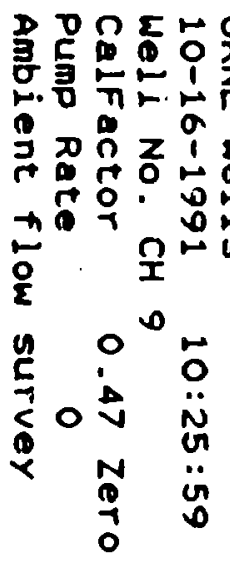

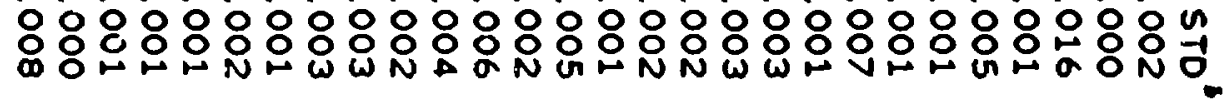
0 0 0 0 0 0000000000000000000 0 0 o

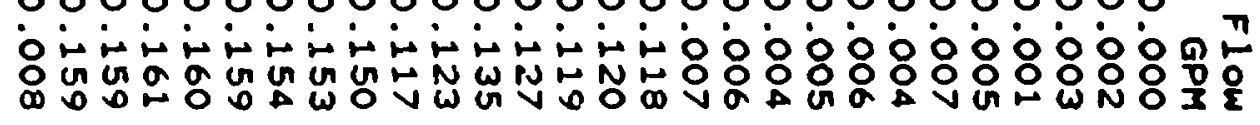

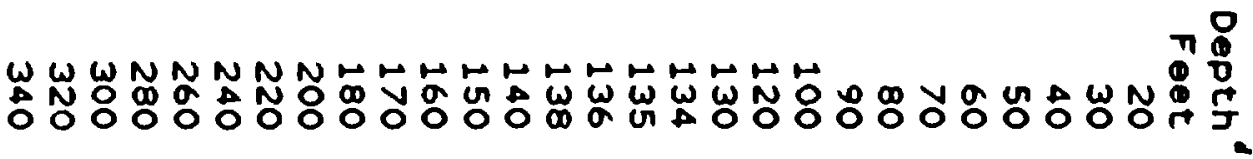




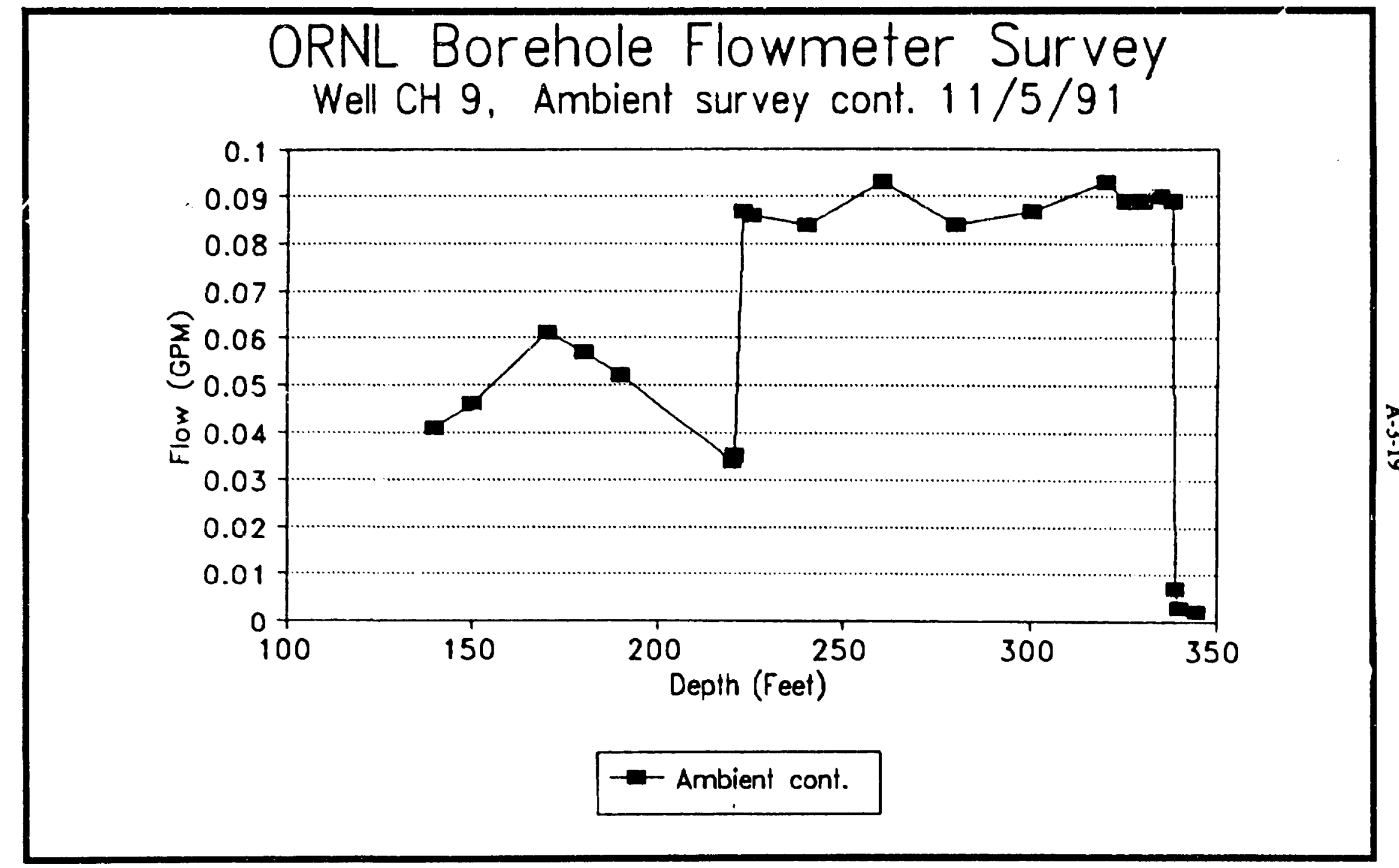

Fig. A3.5. (continued). 
ORNL Borehole flowmeter survey CHOO9, ambient survey November 6, 1991

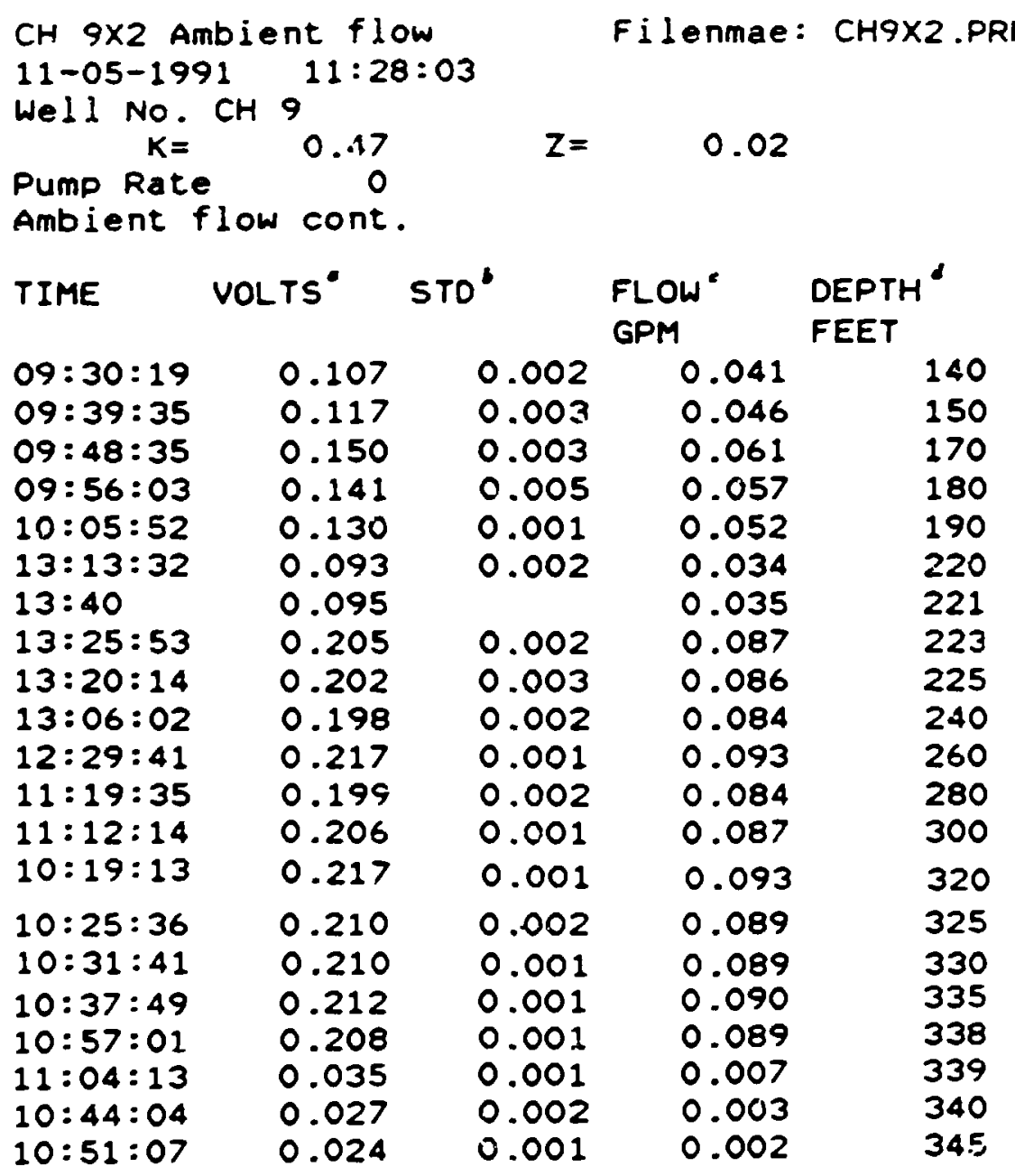

Volts column is analog signal from the flowmeter.

'STD column is standard deviation of the analog signal.

-Ambient surveys measure natural flow (no injection) in the corehole. A plus sign means flow up the hole. Flnw rate is gallons per minute.

Dept.. are measured from top of inner casing. 
ATTACHMENT 4

CH11A-GEOPHYSICAL AND GEOLOGIC DATA 
Table A4.1. Summary of fractures identified in corchole CHIIA

\begin{tabular}{|c|c|c|c|c|c|c|c|c|c|c|}
\hline Depth BOS $(n)$ & $\begin{array}{c}\text { Goologic } \\
\text { unik }\end{array}$ & $\begin{array}{c}\text { Fractures } \\
\text { per } \mathrm{n}\end{array}$ & BHTV & VDL & Caliper & Temperature & $\begin{array}{c}\text { Delta } \\
\text { iemperature }\end{array}$ & $\begin{array}{l}\text { Deviation } \\
\text { nurvey }\end{array}$ & $\mathbf{S P}$ & Comments \\
\hline & & & $* * *(13)$ & & & & & & & \\
\hline $19-20$ & G & 5 & $\mathbf{x}$ & $\mathbf{x}$ & & & & & & 25-40, BP, open to sl. open \\
\hline 20.21 & & 3 & $\mathbf{x}$ & & & & & & & $35^{\circ}$, BP, open \\
\hline $21-22$ & & 5 & $\mathbf{x}$ & $\mathbf{x}$ & & & & & & $20-40^{\circ}$, BP, open \\
\hline $22-23$ & & 2 & $\mathbf{x}$ & & & & & & & $30^{\circ}$, BP, tight and open \\
\hline 23-24 & & 4 & $\mathbf{x}$ & $\mathbf{x}$ & $\mathbf{x}$ & B & & & & $\begin{array}{l}30-40^{\circ}, \text { BP, open to tight; } \perp \text { to bedding, slightly } \\
\text { open }\end{array}$ \\
\hline $24-25$ & & & $\mathbf{x}$ & $\mathbf{x}$ & & B & & & & \\
\hline $25-26$ & & 2 & $\mathbf{x}$ & $\mathbf{x}$ & & & & & & $25-50^{\circ}$, BP, open \\
\hline $26-27$ & & 3 & $\mathbf{x}$ & & & B & $\mathbf{x}$ & & & $30-40^{\circ}$, BP, open \\
\hline $28-29$ & & 3 & $\mathbf{x}$ & $\mathbf{x}$ & & & $x$ & & & $30-35^{\circ}$, BP, si. open \\
\hline $29-30$ & & 2 & & & & & $\mathbf{x}$ & & & $30^{\circ}$, BP, sl. open to open \\
\hline $30-31$ & & 3 & $\mathbf{x}$ & $\mathbf{x}$ & $\mathbf{x}$ & B & $\mathbf{x}$ & & & $35^{\circ}$, BP, open; $\perp$ to bodding \\
\hline 31-32 & & 3 & $\mathbf{x}$ & $\mathbf{x}$ & & & & & & $30^{\circ}$. BP, calcite mineralization, al. open to open \\
\hline $32-33$ & & 3 & $\mathbf{x}$ & $\mathbf{x}$ & & & & & & $20-30^{\circ}$, BP, open \\
\hline $33-34$ & & 2 & & & & & $\mathbf{x}$ & & & $35-40^{\circ}$, BP, tight and open \\
\hline 34-35 & & & $\mathbf{x}$ & & & B & & & & \\
\hline $36-37$ & & 3 & $\mathbf{x}$ & & & & & & & $30-35^{\circ}$, BP open \\
\hline $37-38$ & & 2 & $\mathbf{x}$ & & & & & & & $25-30^{\circ}$, BP, open \\
\hline $39-10$ & & 3 & & & & & & & & $35-40^{\circ}$. BP, s1. open to open \\
\hline$+0-41$ & & 3 & $x$ & $\mathbf{x}$ & & B & & & & $35^{\circ}$, BP, open \\
\hline $41-42$ & & 2 & $\mathbf{x}$ & $\mathbf{x}$ & & & & & & 30-35', BP, open \\
\hline $43-44$ & & 3 & & & & B & & & & 30-35 $5^{\circ}$ BP, open \\
\hline $44-45$ & & 2 & $\mathbf{x}$ & & & & $\mathbf{x}$ & & & 30-40, BP sl. open to open \\
\hline $45-46$ & & 3 & & & $\mathbf{x}$ & & $\mathbf{x}$ & & & $\begin{array}{l}30-40^{\circ} \text {, BP sl. open to open, some calcite } \\
\text { mineralization }\end{array}$ \\
\hline $47-48$ & & & & & & $\mathbf{s}$ & & & & \\
\hline $48-49$ & & 2 & & & & $\mathbf{x}$ & & & & $35^{\circ}$, UP, sl, open to open \\
\hline $49-50$ & & & $\mathbf{x}$ & $\mathbf{x}$ & & & $\mathbf{x}$ & & & \\
\hline 50.51 & & 3 & & $\mathbf{x}$ & $\mathbf{x}$ & $\mathbf{x}$ & & & & $\begin{array}{l}\text { 30-50 } 0^{\circ} \text {, BP, sl. open to open, some calcite } \\
\text { mineralization }\end{array}$ \\
\hline $53-54$ & & & $\mathbf{x}$ & & $\mathbf{x}$ & $\mathbf{x}$ & & $\mathbf{x}$ & & \\
\hline
\end{tabular}

num 
Table $\mathbf{A 4 . 1}$ (continued)

\begin{tabular}{|c|c|c|c|c|c|c|c|c|c|c|}
\hline Depth RGS (n) & $\begin{array}{l}\text { Gookgix } \\
\text { unit }\end{array}$ & $\begin{array}{l}\text { Fractures } \\
\text { per if }\end{array}$ & BHTV & VDL & Calik $x$ & Temperature & $\begin{array}{l}\text { Dela } \\
\text { temperalure }\end{array}$ & $\begin{array}{l}\text { Deviation } \\
\text { survey }\end{array}$ & SP & Comments \\
\hline $55-56$ & & & & & & & $\mathbf{x}$ & & & \\
\hline $63-4$ & & 4 & $\mathbf{x}$ & $\mathbf{x}$ & $\mathbf{x}$ & $\mathbf{x}$ & $\mathbf{x}$ & & & $\begin{array}{l}30^{\circ} \text {, BP, open - thick cakile layer on thottom of } \\
\text { fracture; } \perp \text { to bodding, tight; } 20-30^{\circ} \text {, BP, open }\end{array}$ \\
\hline $66-67$ & & & $\mathbf{x}$ & & $\mathbf{x}$ & $\mathbf{x}$ & & & & \\
\hline $67-68$ & $\mathbf{F}$ & 2 & $\mathbf{x}$ & $\mathbf{x}$ & & & & & & $30-35^{\circ}$, BP, al. open to open \\
\hline $68-69$ & & 4 & $\mathbf{x}$ & & $\mathbf{x}$ & & & & & $\begin{array}{l}28-37^{\circ} \text {. BP, al. open to open; } \perp \text { to bodding plane, } \\
\text { tight }\end{array}$ \\
\hline 20.71 & & 5 & $\mathbf{x}$ & $\mathbf{x}$ & & & & & & $35^{\circ}$, BP, sl. open to tight \\
\hline $71-72$ & & 6 & $\mathbf{x}$ & $\mathbf{x}$ & $\mathbf{x}$ & & & & & $35^{\circ}$, BP, sl. open to tight \\
\hline $7=-73$ & & 3 & & & & & & & & 30-37'. BP. tight \\
\hline $73-74$ & & & & $\mathbf{x}$ & $\mathbf{x}$ & $\mathbf{x}$ & & & $\mathbf{x}$ & \\
\hline $75-76$ & & & $\mathbf{x}$ & $\mathbf{x}$ & & & & $\mathbf{x}$ & & \\
\hline $76-77$ & & & & $\mathbf{s}$ & & & & & & \\
\hline 79.80 & & 2 & & & & & & & & $30^{\circ}$, BP, light to sl. open \\
\hline 80-81 & & 2 & & & & & & & & $30^{\circ}$, BP, open \\
\hline $81-82$ & & 2 & & $\mathbf{x}$ & & & & & & $30^{\circ}$, BP, st. open; $\perp$ to hedding, open \\
\hline 83-84 & & 3 & $\mathbf{x}$ & $\mathbf{x}$ & & B & & & & $30^{\circ}$, BP, open \\
\hline $85-86$ & & & & $\mathbf{x}$ & & $\mathbf{x}$ & $\mathbf{x}$ & & & \\
\hline $85-87$ & & 3 & $\mathbf{x}$ & $\mathbf{x}$ & $\mathbf{x}$ & & & & & $\begin{array}{l}25-35^{\circ} \text {, BP, sl. open to open; } \perp \text { to tedding, sl. } \\
\text { open }\end{array}$ \\
\hline $89-90$ & & & & & $?$ & B & & & & \\
\hline$\$ !-92$ & & & & $\mathbf{x}$ & & & & & & \\
\hline $92-93$ & & 4 & $?$ & & & & & & & $30-50^{\circ}$, BP, s1. open to open \\
\hline $93-94$ & & 4 & $\mathbf{x}$ & & $\mathrm{x}$ & & & & & $30^{\circ}$, BP, sl. open to open \\
\hline $94-95$ & & 6 & $\mathbf{x}$ & & & $\mathbf{x}$ & $\mathbf{x}$ & & & $30-35^{\circ}$, BP, sl. open to tight \\
\hline $95-96$ & & 3 & $\mathbf{x}$ & $\mathbf{X}$ & & & & & & $25-40^{\circ}$, BP, open \\
\hline $96-97$ & & 4 & $?$ & $\mathbf{x}$ & & & & & & $26-30^{\circ}$, BP, open \\
\hline $97-98$ & & 4 & $?$ & $\mathbf{x}$ & & & $\mathbf{X}$ & & & 28-32', BP, open \\
\hline $98-99$ & $\mathbf{E}$ & 2 & $\mathbf{x}$ & & & & & & & $30^{\circ}, \mathrm{BP}$, tight \\
\hline $100-101$ & & 3 & $\mathbf{x}$ & $\mathbf{X}$ & & & & & & $30^{\circ}$, BP, al. open to open; $\perp$ in hedding, open \\
\hline $101 \cdot 102$ & & 2 & $\mathbf{x}$ & $\mathbf{x}$ & & & $\mathbf{x}$ & & & 30-35 , BP, sl. open to open \\
\hline
\end{tabular}


Table A4.1 (continued)

\begin{tabular}{|c|c|c|c|c|c|c|c|c|c|c|}
\hline Depeh BGS (n) & $\begin{array}{c}\text { Geologic } \\
\text { uni: }\end{array}$ & $\begin{array}{c}\text { Fractures } \\
\text { per } \pi\end{array}$ & BHTV & VDL & Caliper & Temperature & $\begin{array}{c}\text { Della } \\
\text { temperature }\end{array}$ & $\begin{array}{c}\text { Devintion } \\
\text { survey }\end{array}$ & SP & Comment: \\
\hline $102-103$ & & 3 & $?$ & & & $\bar{x}$ & $\bar{x}$ & & & $28-31^{\circ}$, BP, s1. open to open \\
\hline $103-104$ & & 3 & $\mathbf{x}$ & & & B & $\mathbf{x}$ & $x$ & & 30-35'. BP, open \\
\hline $100-107$ & & & $?$ & & & & & & $\mathbf{s}$ & \\
\hline $108-109$ & & & & & & $\mathbf{x}$ & $\mathbf{x}$ & & $\mathbf{x}$ & \\
\hline $112-113$ & & 2 & & & $\mathbf{x}$ & $\mathbf{x}$ & $\mathbf{x}$ & & $\mathbf{x}$ & $30^{\circ}$, BP, open; $\perp$ to bodding, open \\
\hline $114-i 15$ & & & & & $?$ & $\mathbf{x}$ & $\mathbf{x}$ & $\mathbf{x}$ & & \\
\hline $120-121$ & & 2 & $\mathbf{x}$ & & & B & & $\mathbf{x}$ & $\mathbf{x}$ & $25-30^{\circ}$, BP, open; cakcite miseralization \\
\hline $121-122$ & & 2 & & $\mathbf{x}$ & & & & & & $30^{\circ}$, BP, open; calcine mineralization \\
\hline $122 \cdot 123$ & & 2 & $\mathbf{x}$ & & $\mathbf{x}$ & & & & $\mathbf{x}$ & $34-35^{\circ}$, BP, open \\
\hline $124-125$ & & & $\mathbf{x}$ & & & $\mathbf{x}$ & & & $\mathbf{x}$ & \\
\hline 125.126 & & & $\mathbf{x}$ & $\mathbf{s}$ & & & & & & \\
\hline 126.127 & & 3 & $\mathbf{x}$ & & & & $\mathbf{x}$ & & & 30-37', BP, al. open to tight \\
\hline $127-128$ & & 3 & $?$ & & $\mathbf{x}$ & & & & & $22-32^{\circ}$, BP, open \\
\hline $120-130$ & & & & & $\mathbf{x}$ & & $\mathbf{x}$ & $\mathbf{x}$ & & \\
\hline $132-133$ & & 2 & & & $\mathbf{x}$ & & $\mathbf{x}$ & & & $30-32^{\circ}$, BP, open \\
\hline $133-134$ & & & & & & & $\mathbf{x}$ & & & \\
\hline $13+135$ & & & $?$ & & & & & $\mathbf{x}$ & & \\
\hline $136-137$ & & & $++t$ & & $\mathbf{x}$ & $\mathbf{x}$ & & & & \\
\hline $141-142$ & & 2 & & $\mathbf{x}$ & & & $\mathbf{x}$ & & & $30-34^{\circ}$, BP, open \\
\hline $142-143$ & & & & $\mathbf{x}$ & & $\mathbf{x}$ & & & & \\
\hline $146-147$ & & 2 & & & & B & & $\mathbf{x}$ & $\mathbf{x}$ & $35^{\circ}$. BP, sl. open to open \\
\hline 153.154 & & 2 & & & & & & $x$ & & $35^{\circ}$, BP, open \\
\hline$i 55-156$ & & & & & $\mathbf{x}$ & & & & & \\
\hline $158-159$ & & & & 3 & & & $\mathbf{x}$ & & $\mathbf{x}$ & \\
\hline $162-163$ & & & & & & B & $\mathbf{s}$ & $\mathbf{x}$ & $\mathbf{x}$ & \\
\hline $165-166$ & & & & & $\mathbf{s}$ & & & $\mathbf{x}$ & & \\
\hline $170-171$ & & 2 & & & & & & $\mathbf{x}$ & $\mathbf{x}$ & 35-37, BP, open, calcite mineralization \\
\hline $173-174$ & & & & & & B & & & $\mathbf{x}$ & \\
\hline $179-180$ & & & & & & $\mathbf{x}$ & $y$ & $\mathbf{x}$ & & \\
\hline $182-183$ & & & & & $\mathbf{s}$ & & & $\mathbf{x}$ & & \\
\hline ruson & & & & & & & & & & \\
\hline
\end{tabular}


Table A4.1 (continued)

\begin{tabular}{|c|c|c|c|c|c|c|c|c|c|c|}
\hline Depth BGS (t) & $\begin{array}{l}\text { Geologic } \\
\text { unit }\end{array}$ & $\begin{array}{c}\text { Fractures } \\
\text { per it }\end{array}$ & BHTV & VDL & Caliper & Temperature & $\begin{array}{c}\text { Deks } \\
\text { temperature }\end{array}$ & $\begin{array}{c}\text { Deviation } \\
\text { survey }\end{array}$ & $\mathbf{S P}$ & Commentes \\
\hline $134-185$ & & & & & $\mathbf{s}$ & & & & & \\
\hline $186-187$ & & & & & & & & & $\mathbf{x}$ & \\
\hline $187-188$ & & $\mathbf{0}$ & & & & & & $\mathbf{x}$ & & Healod fracture (calcite fillod), $35{ }^{\circ}$ \\
\hline $189-190$ & & & & $\mathbf{s}$ & $\mathbf{s}$ & & $\mathbf{x}$ & $\mathbf{x}$ & & \\
\hline $192-193$ & & & & & & & $\mathbf{x}$ & & $\mathbf{x}$ & \\
\hline $197-198$ & & & & $\mathbf{s}$ & $\mathbf{x}$ & & & & & \\
\hline $203-204$ & & & & & $\mathbf{x}$ & & & $\mathbf{x}$ & $\mathbf{x}$ & \\
\hline $211-212$ & & & & & & & $\mathbf{x}$ & & & \\
\hline $213-214$ & & 2 & & & $\mathbf{x}$ & & & & & 35-39॰, BP, il. open to open \\
\hline $214-215$ & & & & & s & & & $\mathbf{x}$ & & \\
\hline $216-217$ & & & & & & B & & & & \\
\hline 222.223 & & & & & $\mathbf{x}$ & & & & & \\
\hline 223-224 & & 2 & & & & & & & & $30^{\circ}$, BP, open \\
\hline $225-226$ & & 3 & & $\mathbf{x}$ & $\mathbf{X}$ & & & & & 30-35, BP, sl. open to open \\
\hline $226-227$ & & 4 & & $\mathbf{x}$ & & $\mathbf{x}$ & & & & $30-35^{\circ}$, BP, sl. open to open \\
\hline 227.228 & & 3 & & $\mathbf{x}$ & & & & & & $22-32^{\circ}$. BP, sl. open to open \\
\hline $228-229$ & & 3 & & $\mathbf{x}$ & $\mathbf{x}$ & & & $\mathbf{x}$ & & $30-32^{\circ}$, BP, s1. open to open \\
\hline $231-232$ & & 2 & & & & & & $\mathbf{x}$ & & $30^{\circ}$, BP, sl. open to open \\
\hline $232-233$ & & 2 & & & & & & & & $25^{\circ}$, BP, open \\
\hline $233-234$ & & & & & & B & $s$ & $\mathbf{x}$ & & \\
\hline 237.238 & & 2 & & $\mathbf{s}$ & $\mathbf{x}$ & & s & $\mathbf{x}$ & & 25-30 , BP, open, calcile mincralization \\
\hline $245-246$ & & & & $s$ & $\mathbf{x}$ & $\mathbf{x}$ & & $\mathbf{x}$ & & \\
\hline $247-248$ & & & & & $x$ & & & & & \\
\hline $252-253$ & & & & & $\mathbf{x}$ & & & $\mathrm{x}$ & & \\
\hline $256-257$ & & & & $\mathbf{s}$ & $\mathbf{x}$ & & & $\mathbf{x}$ & $\mathbf{x}$ & \\
\hline 258.259 & & & & s & & & s & & $\mathbf{x}$ & \\
\hline $262-263$ & & & & $\mathbf{s}$ & & & & & & \\
\hline $263-264$ & & & & & $\mathbf{x}$ & & & & & \\
\hline $266-267$ & & & & & $\mathbf{x}$ & $\mathbf{B}$ & & & & \\
\hline $271-272$ & & & & & & & & & s & \\
\hline
\end{tabular}


Table A4.1 (continued)

\begin{tabular}{|c|c|c|c|c|c|c|c|c|c|c|}
\hline Depth BGS (ft) & $\begin{array}{l}\text { Goologic } \\
\text { unit }\end{array}$ & $\begin{array}{c}\text { Fractures } \\
\text { per it }\end{array}$ & BHTV & VDL & Caliper & Temperature & $\begin{array}{c}\text { Delta } \\
\text { temperature }\end{array}$ & $\begin{array}{c}\text { Deviation } \\
\text { survey }\end{array}$ & $\mathbf{S P}$ & Comments \\
\hline $275-276$ & & & & $\mathbf{S}$ & & & & & & \\
\hline $278-279$ & & & & & & $\mathbf{X}$ & & & & \\
\hline $279-280$ & & & & & & & $\mathbf{s}$ & & & \\
\hline $281-282$ & & 2 & & & & & \multicolumn{4}{|c|}{$30-34^{\circ}$, BP, open } \\
\hline
\end{tabular}

Only those depth ixtervals obtained from the geologist's loga have an accuracy of $0.1 \mathrm{ft}$. Depth intervals from other logs were not as accurate.

'From grologist's log.

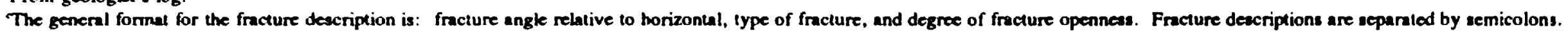

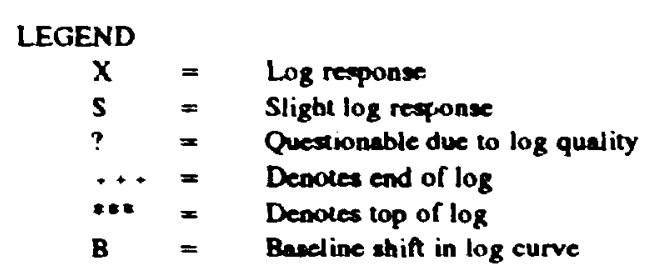

1. BP - Bodding plane fracture; a fracture that occurs along the plane of bodding. which typically rangod from $25-40^{\circ}$ as measured perpendicular to the long axis of the core.

2. Dip-normal frecture - Any frecture that is perpendicular to bodding: lypically either parallel or perpendicular to strike.

3. Dip-parallel frecture - Any frecture that is paralled to bedding.

4. Low angle fracture - As measured perpendicular to the long axis of the core, a low angle fracture is generally at an angle less than bedding.

5. High angle fracture - As measured perpendicular to the long axis of the core, a high angle fracture is generally at an angle greater than bedding.

6. $\perp$ - A dip-norn.al fracture: perpendicular to bodding. 


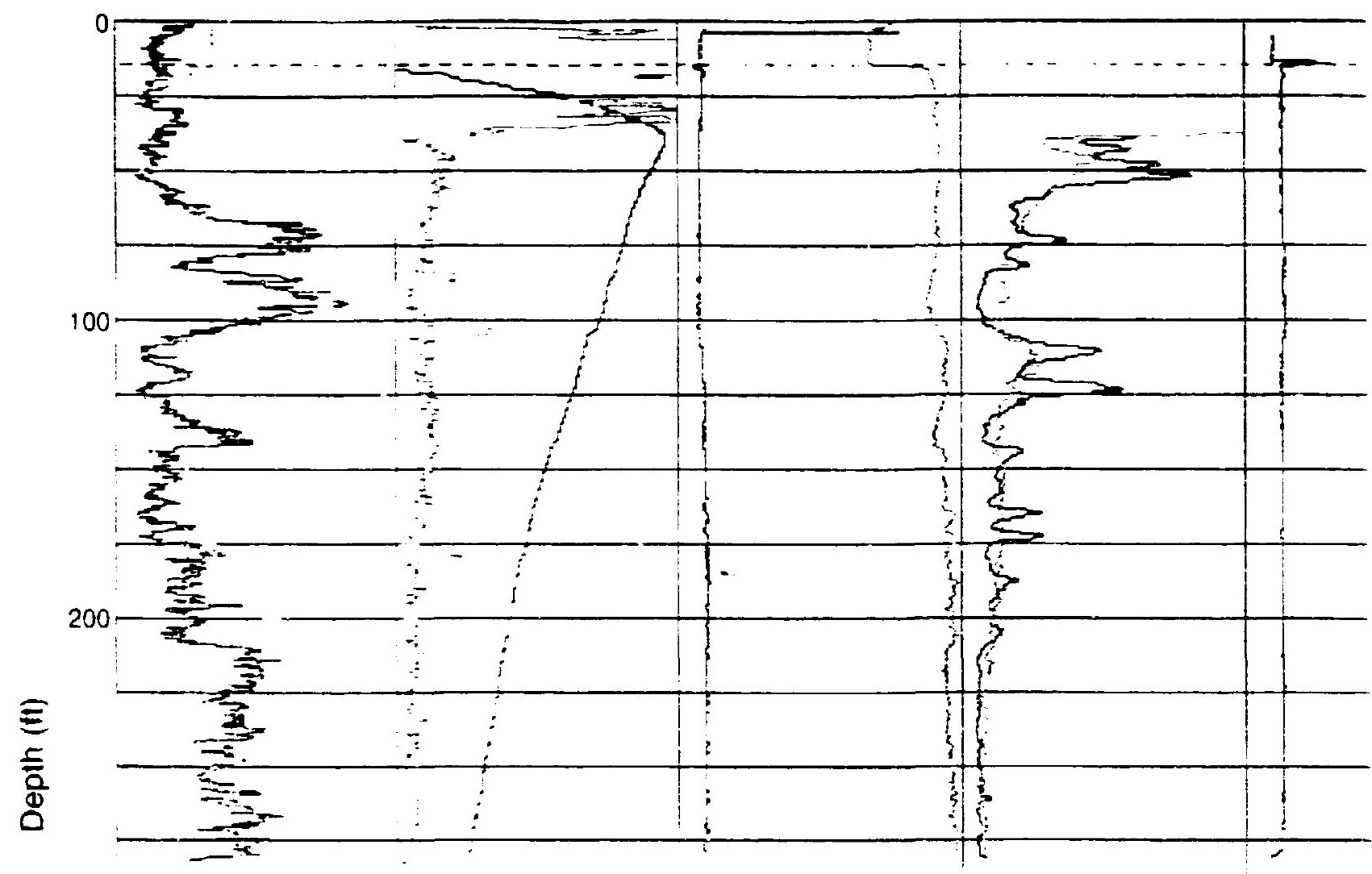

300

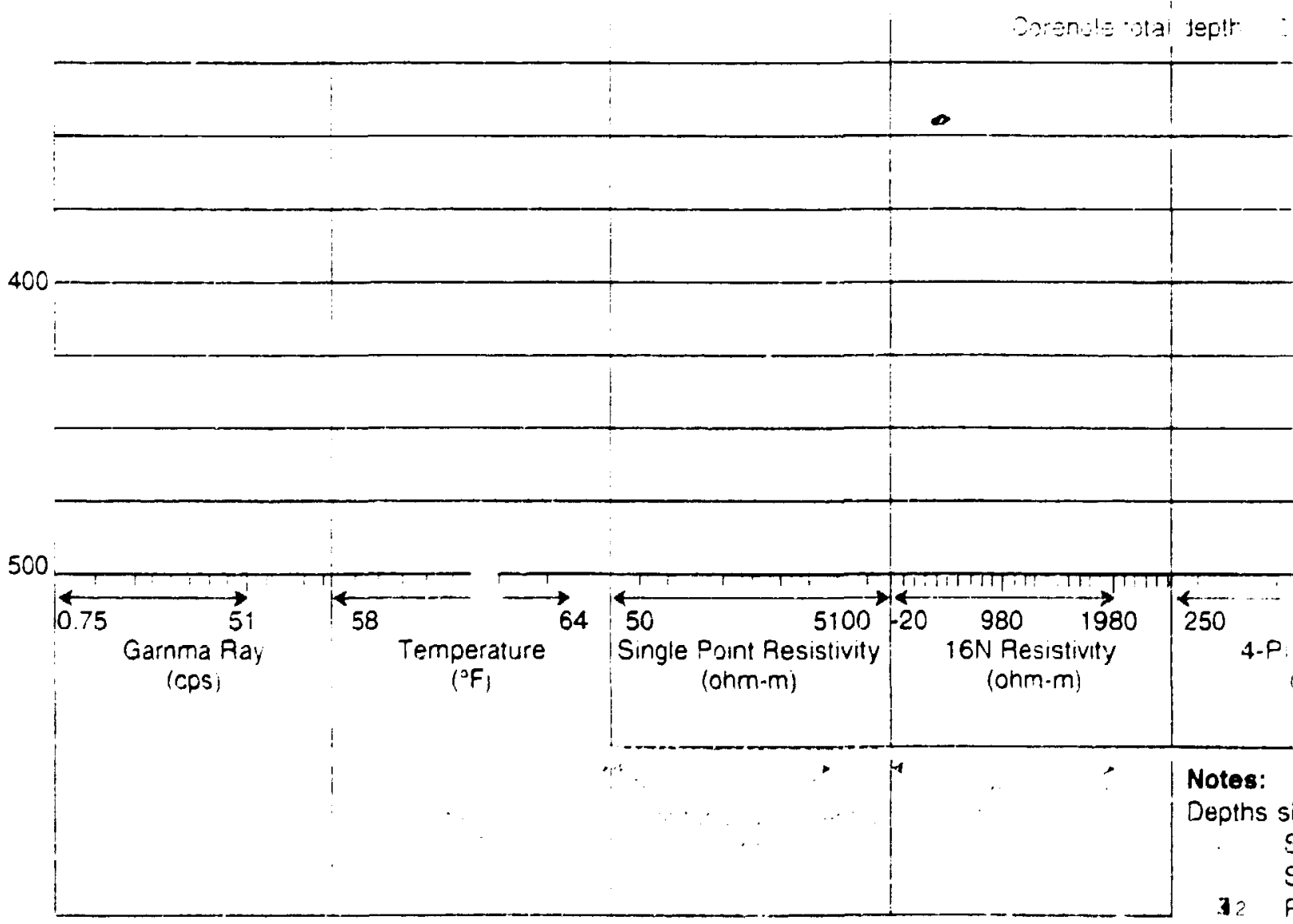




\section{A-4-7}

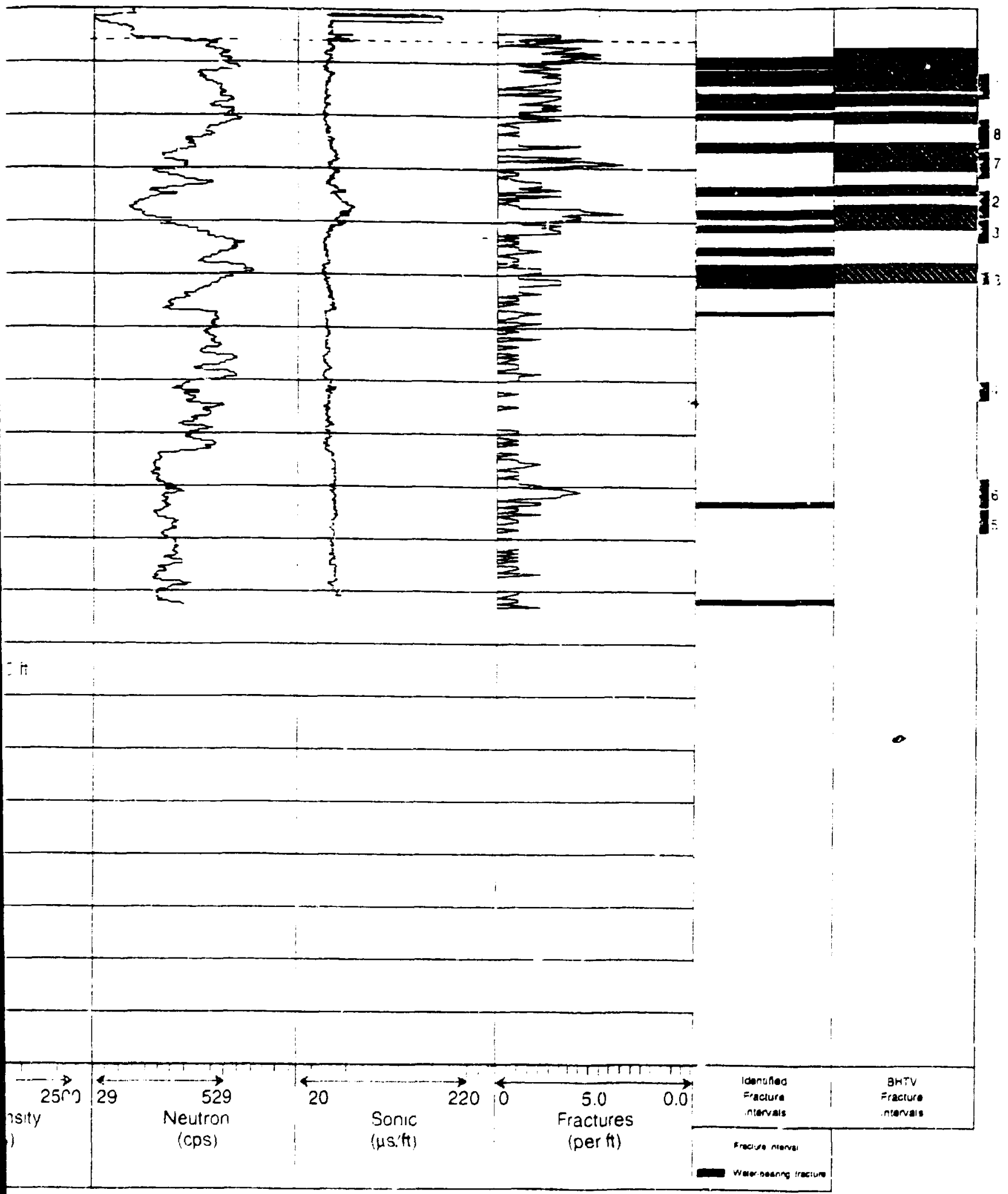

In are from ground surface

ace casing depth $=15.3 \mathrm{ft}$

c. water level at time of logging $=2 \mathrm{H}$

er test interval

Fig. A 4.1. CH011 A borehole geophysical logs. 


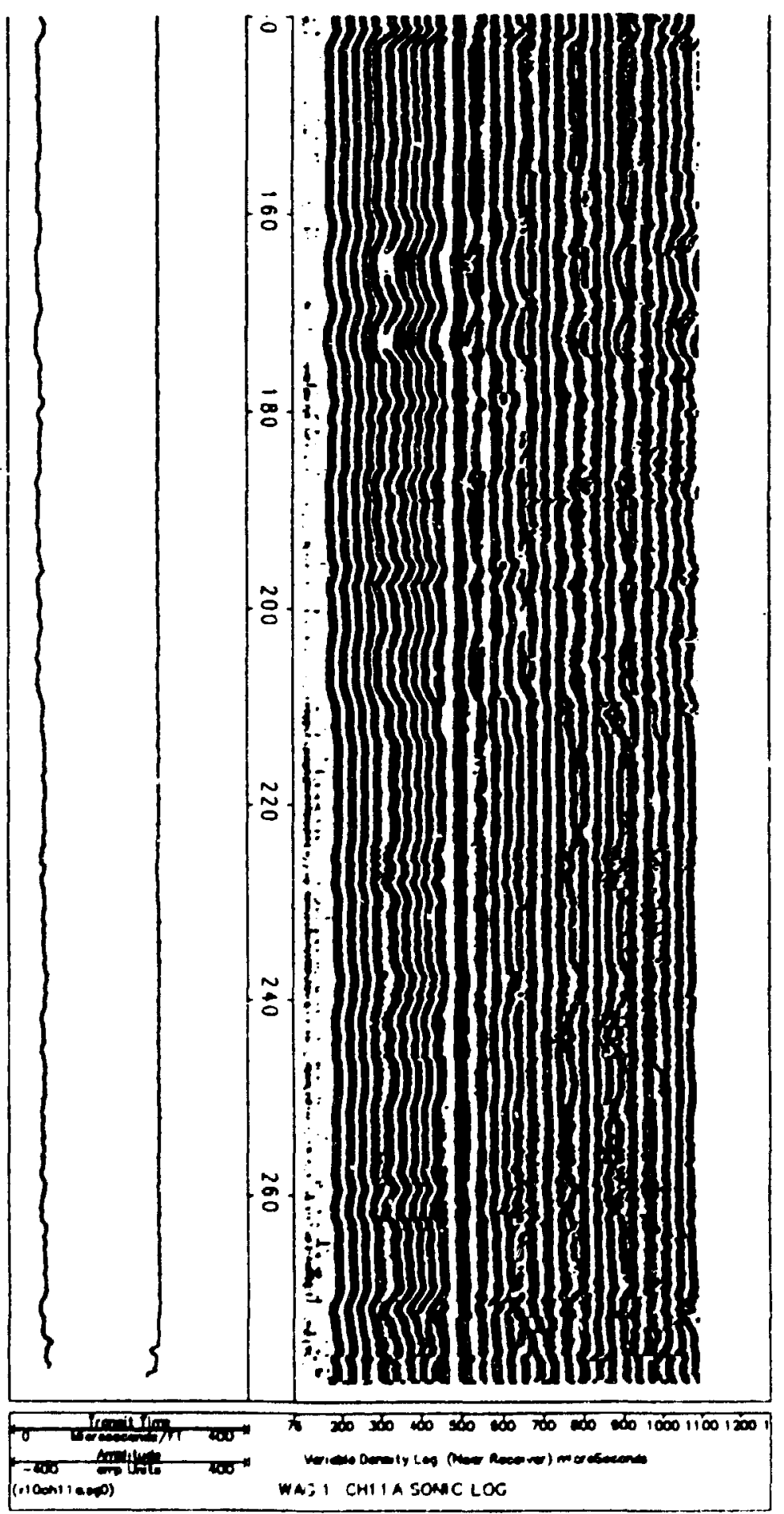

Fig. A4.2. CH011A variable density (acoustic) log. 


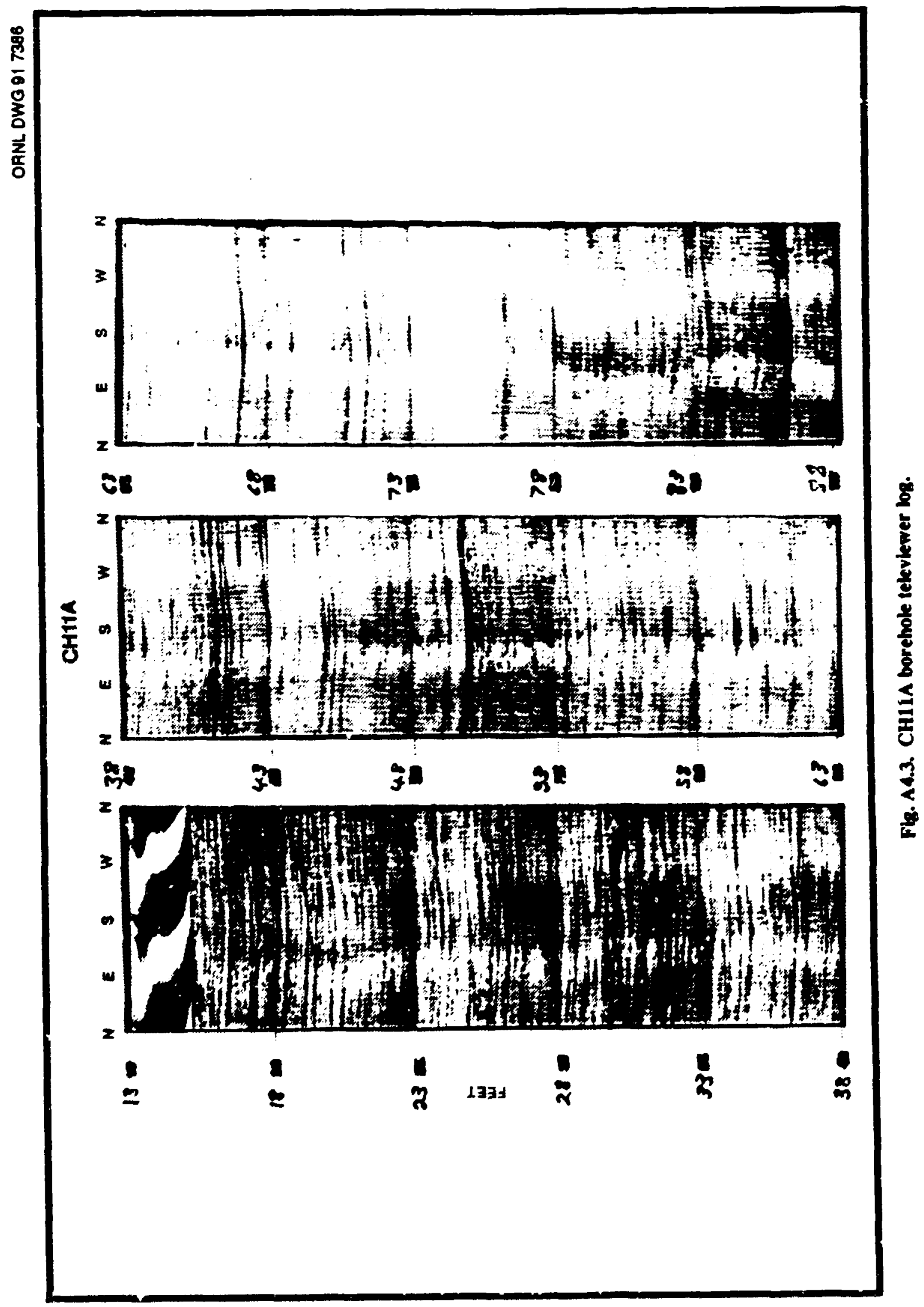




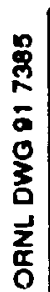

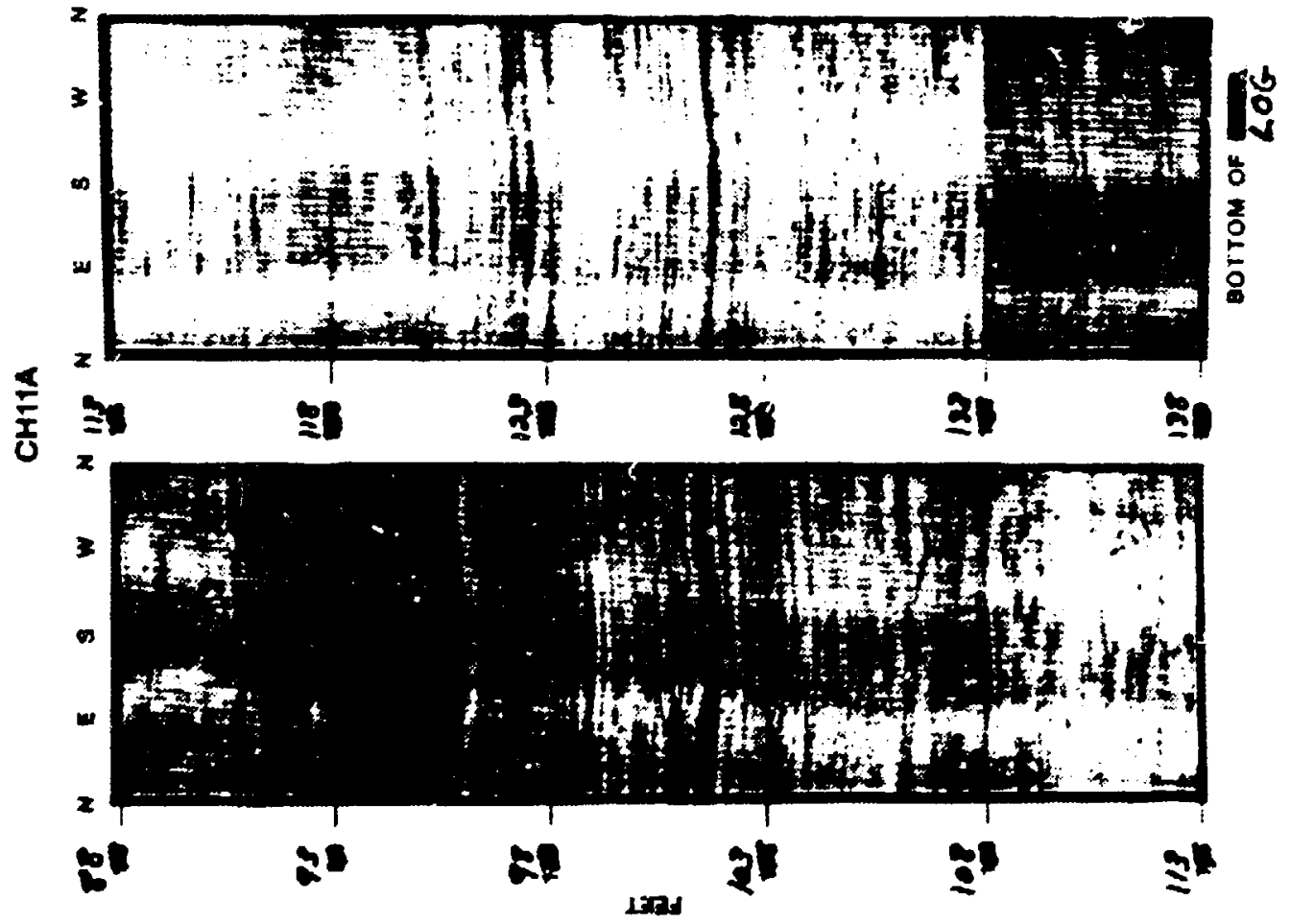


CH1IA OWL Deviation Probe Data

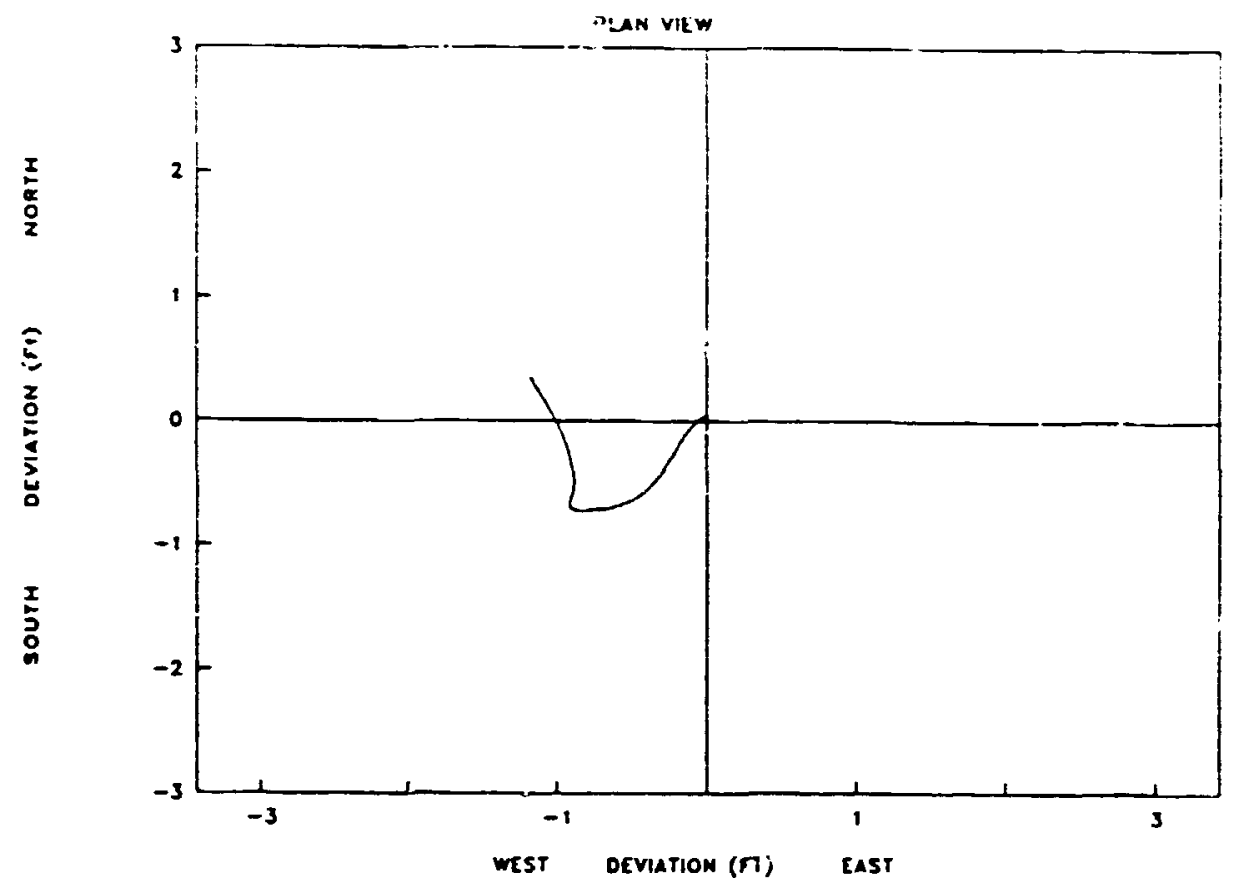

CH11A OWL Deviation Probe Data

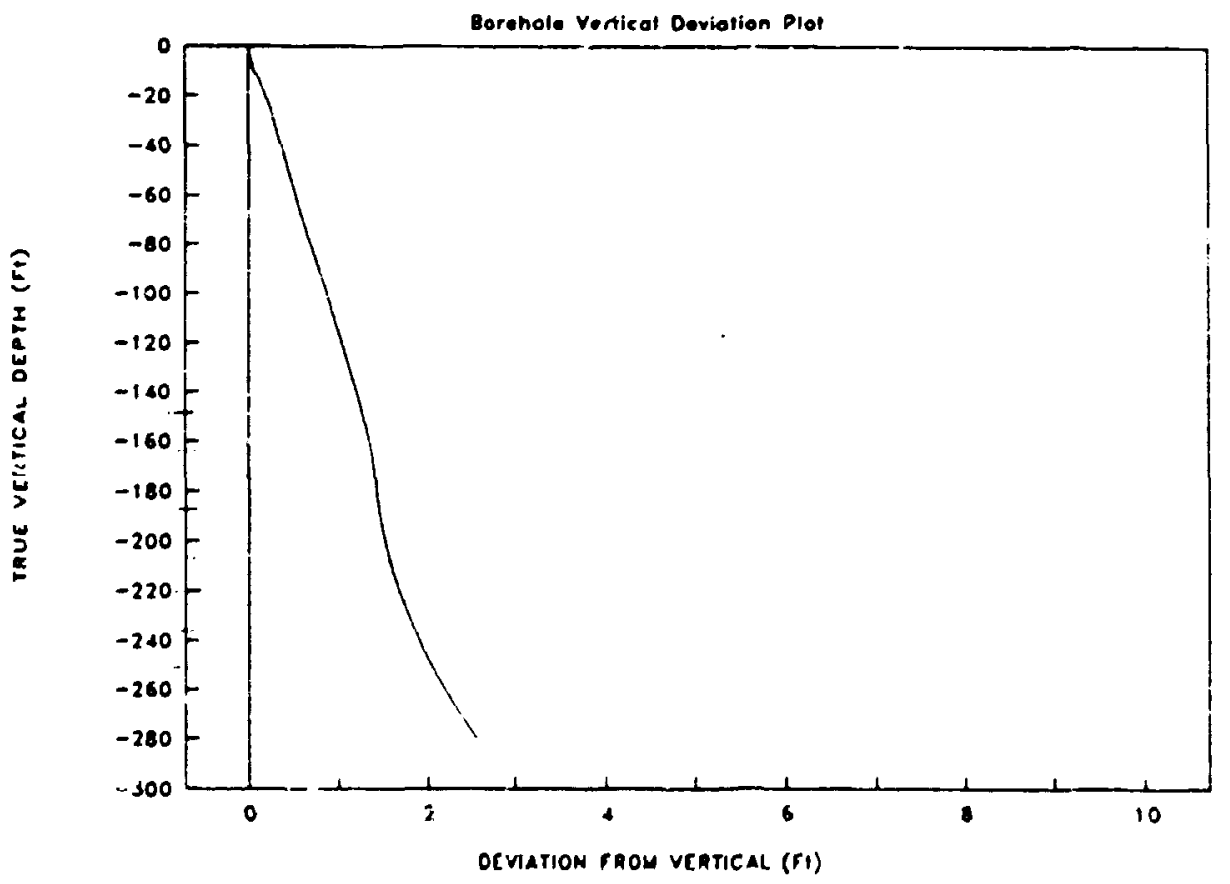

Fig. A4.4. CH011A OWL deviation probe data. 
CH1IA OWL Deviation Probe Data EAS: - WEST CROSS SECTION

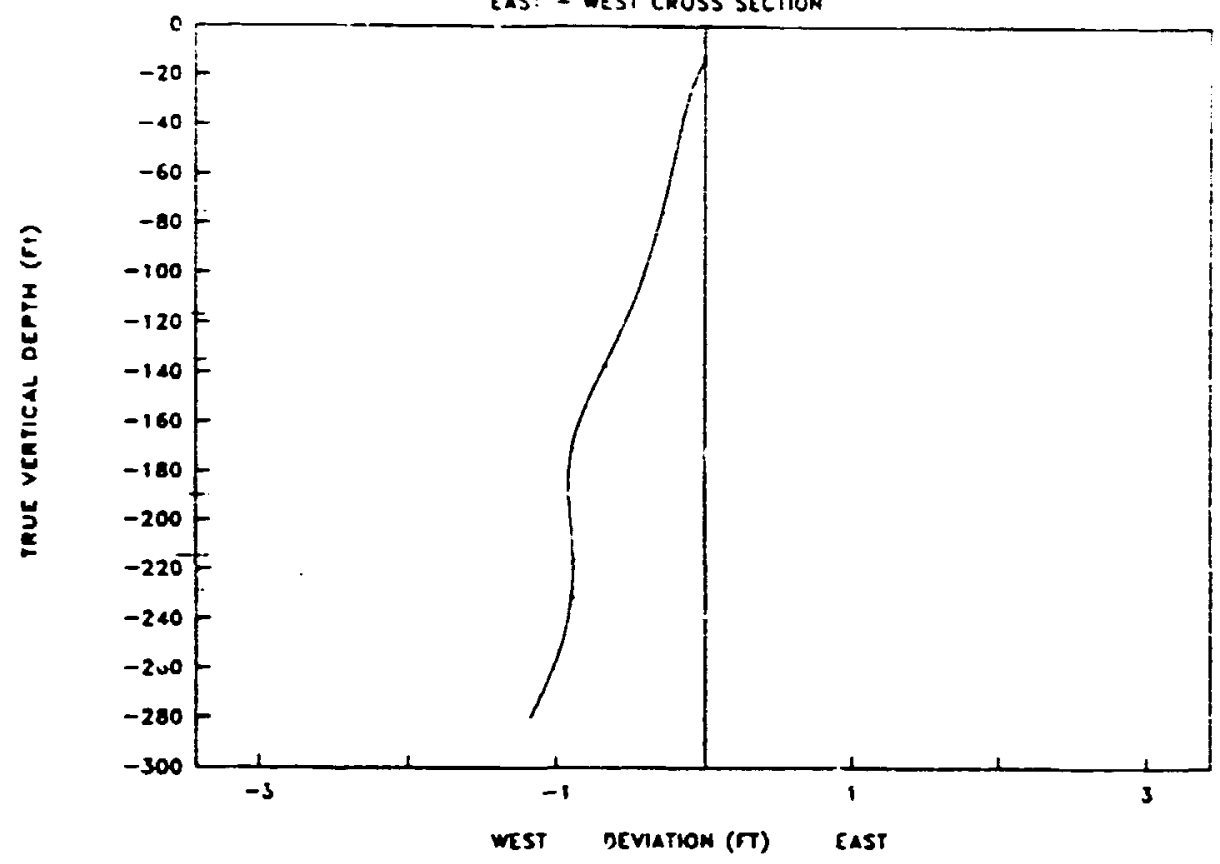

CH11A OWL Deviation Probe Data

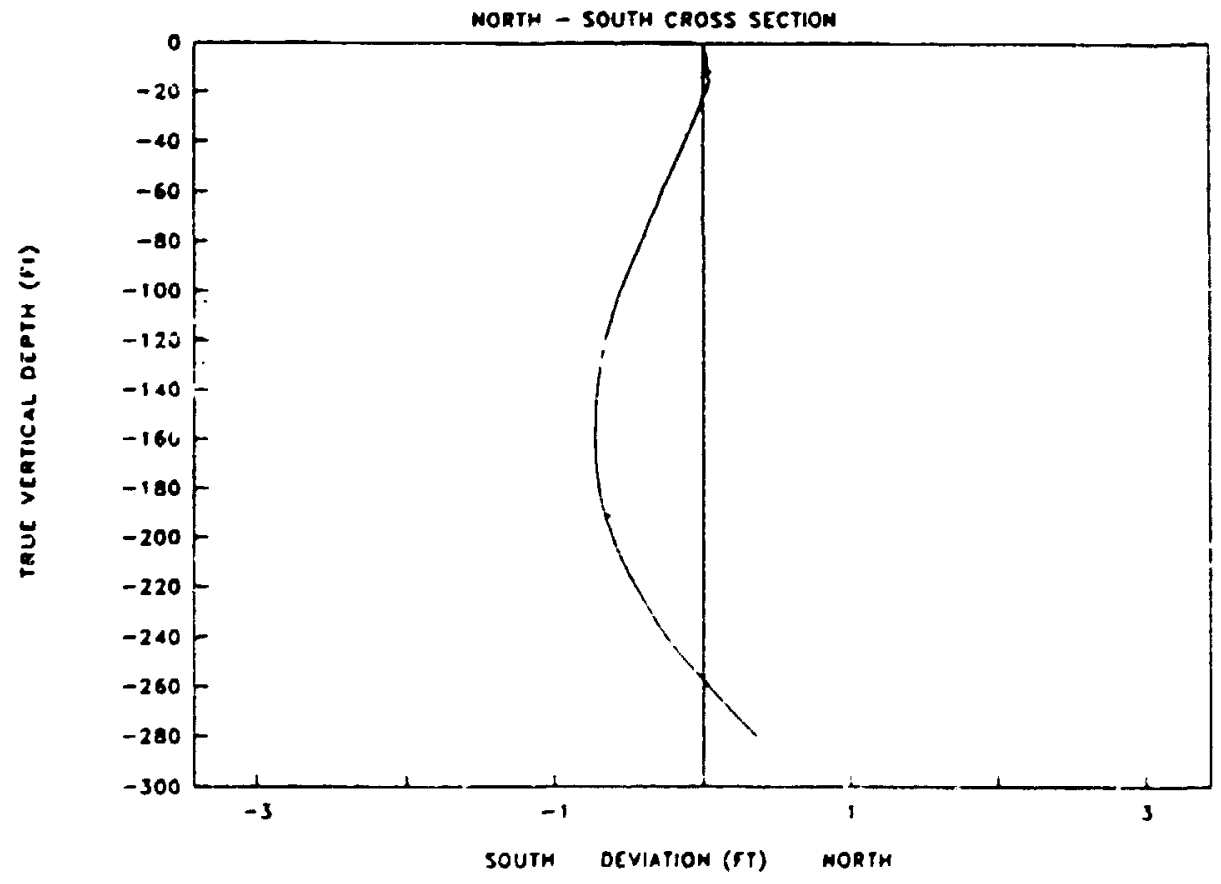

Fig. A4.4. (continued). 
ATTACHMENT 5

CH012-GEOPHYSICAL AND GEOLOGIC DATA 
Tahle A5.1. Summary of fractures identified in corehole CHO12

\begin{tabular}{|c|c|c|c|c|c|c|c|c|c|}
\hline $\begin{array}{l}\text { Depth BGS } \\
\text { (t) }\end{array}$ & $\begin{array}{l}\text { Geologic } \\
\text { init }\end{array}$ & $\begin{array}{l}\text { Fractures } \\
\text { per } f t\end{array}$ & BHTV & VDL & Caliper & Tempernture & $\begin{array}{c}\text { Della } \\
\text { tempernture }\end{array}$ & sP & Coummentsed \\
\hline $19.1-20.1$ & н & 2 & $* *(15)$ & & & & & & $\begin{array}{l}\text { Dip-normal, dip-parallel fructure sa is high } \\
\text { angle, strike is light, dip in open }\end{array}$ \\
\hline $23.1-24.1$ & & 3 & $\mathbf{x}$ & $x$ & & & & & $\begin{array}{l}28^{\circ}, \text { BP, open; } \perp \text { to core axis, tight and } \\
\text { open, calcile crystals }\end{array}$ \\
\hline $24-25$ & & & $?$ & & & & & & \\
\hline $25-27$ & & & $\mathbf{x}$ & $\mathbf{x}$ & $\mathbf{x}$ & & & & \\
\hline $23.1 \cdot 29.1$ & & 5 & $\mathbf{x}$ & & & & & & $\begin{array}{l}22-33^{\circ} \text {, BP, open to tight; } 0^{\circ} \text {, fracture } \\
\text { surface, tight }\end{array}$ \\
\hline $29.1-30.1$ & & 2 & $\mathbf{x}$ & & & & & & $\begin{array}{l}30^{\circ}, \text { BP, open: } 43^{\circ} \text {, high angte fracture, il. } \\
\text { open }\end{array}$ \\
\hline $30.4-3: .4$ & & 3 & $?$ & $\mathbf{x}$ & & B & & & 28-30 , BP, open, calcile mineralization \\
\hline $32.4-33.4$ & & 3 & $?$ & $\mathbf{x}$ & & $\mathbf{x}$ & & & 28-30', BP, sl. open, calcile mineralization \\
\hline $34.4-354$ & & 4 & $?$ & $\mathbf{x}$ & & $\mathbf{x}$ & & $\mathbf{s}$ & $\begin{array}{l}30^{\circ} \text {, BP, fairly light, calcite fill; open } \\
\text { fraclure: }\end{array}$ \\
\hline $35.4-36.4$ & & 2 & $\mathbf{x}$ & & & & & & 28-30. BP, open \\
\hline $36.4-37.4$ & & 4 & $?$ & & & B & $\mathbf{x}$ & & $\begin{array}{l}28.30^{\circ} \text {. BP, al. open to tight; small } \perp \text { to } \\
\text { he:Iding open tracture }\end{array}$ \\
\hline $38.4-39.4$ & & 2 & $\mathbf{x}$ & $\mathbf{x}$ & & & $\mathbf{x}$ & & $30^{\circ}$, BP, calcile mineralization \\
\hline $30.4-40.4$ & & 3 & $\mathbf{x}$ & $\mathbf{x}$ & & & & & $\begin{array}{l}10-20^{\circ} \text {, low angle fracture, sl. open to tight: 䒧 } \\
30^{\circ}, B p^{2}\end{array}$ \\
\hline $40.4-41.4$ & & 2 & & & & & & & $28^{\circ}$, BP, sl. open \\
\hline $44.4-45.4$ & & 2 & & & & & $\mathbf{x}$ & & $30^{\circ}$, BP: $\perp$ to bedding ol. open fracture \\
\hline $454-46.4$ & & 2 & $?$ & & $\mathrm{x}$ & & & & $30^{\circ}$, BP, tight; Large subvertical open frncture \\
\hline $48.4-49.4$ & & 3 & $\mathbf{x}$ & & & $\mathbf{x}$ & $\mathbf{x}$ & & $30^{\circ}$, BP, si. open \\
\hline $61-63$ & & & $\mathbf{x}$ & $\mathbf{x}$ & & & & & \\
\hline $63.4-64.4$ & & 2 & $?$ & & & & $\mathbf{x}$ & & $\begin{array}{l}35^{\circ} \text {. BP, sl. open; } 30^{\circ} \text { fractur. } \perp \text { to } \\
\text { bedding, open }\end{array}$ \\
\hline $65-66$ & & & $\mathbf{x}$ & & & $\mathbf{x}$ & $\mathbf{x}$ & & \\
\hline 67.4 .68 .4 & & 2 & & & & $\mathbf{x}$ & & & $\begin{array}{l}\text { High angle }\left(40^{\circ}\right) \perp \text { to bedding fracture; high } \\
\text { angle }\left(50^{\circ}\right) \text { parallel bedding iracture, } \perp \text { to } \\
\text { previous fracture }\end{array}$ \\
\hline 70.4 .71 .4 & & $\mathbf{3}$ & $\mathbf{x}$ & $\mathrm{x}$ & & & $\mathrm{x}$ & & $30^{\circ}$, BP, open and tight \\
\hline 74.76 & & & & & & & $?$ & & \\
\hline 79.80 & & & $\mathbf{x}$ & $\mathbf{x}$ & & B & & $\mathbf{s}$ & \\
\hline 82.4 .83 .4 & & 2 & $\mathbf{x}$ & & $\mathbf{x}$ & & $\mathbf{x}$ & & $26^{\circ}$, BP, tight \\
\hline 86-87 & & & $\mathbf{x}$ & $x$ & & & & & \\
\hline 87.488 .4 & & 2 & & $x$ & & $\mathbf{x}$ & $x$ & & $28^{\circ}$. BP, tight \\
\hline
\end{tabular}


Table A5.1 (continued)

\begin{tabular}{|c|c|c|c|c|c|c|c|c|c|}
\hline $\begin{array}{l}\text { Depth BGS } \\
\text { (A) }\end{array}$ & $\begin{array}{c}\text { Goologic } \\
\text { unit }\end{array}$ & $\begin{array}{c}\text { Fractures } \\
\text { per } n\end{array}$ & BHTV & VDL & Caliper & Temperature & $\begin{array}{c}\text { Dekt } \\
\text { tempenture }\end{array}$ & SP & Comments.d \\
\hline $92-93$ & & & $x$ & $?$ & & & $\bar{x}$ & & \\
\hline 95-97 & & & $\mathbf{x}$ & $\mathbf{x}$ & & B & $x$ & & \\
\hline $101-102$ & & & $i$ & & & & & & \\
\hline $102-103$ & & & $\mathbf{x}$ & $\mathbf{x}$ & & $x$ & $\mathbf{x}$ & & \\
\hline $111.4-112.4$ & & 2 & $?$ & & & & & & $29-32^{\circ}$, BP, tight \\
\hline $113.4-114.4$ & & 2 & & & & & & & $20-22^{\circ}$, BP, light \\
\hline $126-127$ & & & $x$ & & $\mathbf{x}$ & & & & \\
\hline $127-128$ & & & & $\mathbf{x}$ & & $\mathrm{x}$ & & & \\
\hline $128.2-129.2$ & & 2 & & $\mathbf{x}$ & & & $\mathbf{x}$ & & $25^{\circ}$, BP, sl. open to tight \\
\hline $130.2-131.2$ & & 2 & $\mathbf{x}$ & $\mathbf{x}$ & & & & & $23^{\circ}$, BP, sl, open to open \\
\hline $131-132$ & & & & $\mathbf{x}$ & & & & & \\
\hline $132 \cdot 133$ & & & $\mathrm{x}$ & & & & $\mathbf{x}$ & & \\
\hline $136-137$ & & & & & & & $\mathbf{x}$ & & \\
\hline 141.143 & & & $x$ & $\mathbf{x}$ & $\mathbf{x}$ & B & & $\mathbf{s}$ & \\
\hline 143.145 & & & & $\mathbf{x}$ & & B & & & \\
\hline $151-152$ & & & $\mathbf{x}$ & $\mathbf{x}$ & & & $\mathbf{x}$ & & \\
\hline $152.2-153.2$ & ? & 3 & $?$ & $\mathbf{x}$ & & & $\mathbf{x}$ & & $\begin{array}{l}47^{\circ} \text {, high angle incture, open: low nngle } \\
\text { frecture surface, open }\end{array}$ \\
\hline 153.154 .2 & G & & $x$ & $\mathbf{x}$ & $\mathrm{x}$ & $\mathbf{x}$ & $\mathbf{x}$ & & \\
\hline $156.2-157.2$ & $?$ & 3 & $\mathbf{x}$ & $\mathbf{x}$ & & $\mathbf{x}$ & & & $33-40^{\circ}$, BP, at. open to tight \\
\hline $157.2-158.2$ & & 3 & $\mathbf{x}$ & $\mathbf{x}$ & & & & & 35. BP, sl. open \\
\hline $.59 .2 \cdot 160.2$ & & 4 & $?$ & & & & $\mathbf{x}$ & & $30^{\circ}$, BP, sl. open to tight \\
\hline $165.2-166.2$ & & 2 & $\dot{x}$ & & & B & & & $26^{\circ}$, BP, tight \\
\hline $168-169$ & & & $x$ & & & B & $\mathbf{x}$ & & \\
\hline $174.2-175.2$ & & 2 & & & & & & & $24-28^{\circ}$, BP, tight \\
\hline 175.176 & & & & $\mathbf{s}$ & $\mathbf{x}$ & & $\mathbf{x}$ & & \\
\hline $170.2-177.2$ & & 2 & $\mathbf{x}$ & & & & & & $28-34^{\circ}$, BP, sl. open to tight \\
\hline 179.180 & & & & & & $\mathbf{x}$ & & & \\
\hline $181-182$ & & & $x$ & & & & & & \\
\hline $182 \cdot 183$ & & & $x$ & & $\mathbf{x}$ & $x$ & & & \\
\hline $184.2-185.2$ & & 2 & & & & & & & $40-43^{\circ}$, BP, tight \\
\hline$i 87.188$ & & & $\mathbf{i}$ & & & & & & \\
\hline $188.2-189.2$ & & 2 & $\mathbf{x}$ & & & & & & $33-35^{\circ}$, BP, tight \\
\hline $192-193$ & & & $\mathbf{x}$ & & & & & & \\
\hline 193.195 & & & & $s$ & & & & & \\
\hline
\end{tabular}

TMeo? 
Table A5.1 (contireued)

\begin{tabular}{|c|c|c|c|c|c|c|c|c|c|}
\hline $\begin{array}{l}\text { Depth BGS } \\
\text { (R) }\end{array}$ & $\begin{array}{c}\text { Geologic } \\
\text { unii }\end{array}$ & $\begin{array}{l}\text { Fractures } \\
\text { per } \mathrm{A}\end{array}$ & BHTV & VDL & Caliper & Tempenture & $\begin{array}{c}\text { Delta } \\
\text {-mperature }\end{array}$ & $\mathbf{S P}$ & Commenis \\
\hline $198.2-199.2$ & & 2 & $x$ & & & & & & $30^{\circ}, \mathrm{BP}$, tight \\
\hline $199.2-200.2$ & & 3 & $\mathbf{x}$ & $\mathbf{x}$ & & B & & & $27-32^{\circ}$, BP, al. open to tight \\
\hline $200.2-201.2$ & & 2 & $\mathbf{x}$ & $x$ & $\mathbf{x}$ & & & & $27.29^{\circ}$, BP, tight \\
\hline $202.2-203.2$ & & 3 & $?$ & & & & & & $\begin{array}{l}25-30^{\circ} \text {, BP, tight: } 18^{\circ} \text {, low angle fracture, s1. } \\
\text { open }\end{array}$ \\
\hline 203-204 & & & $?$ & & & & & & \\
\hline $204.2-205.2$ & & 2 & & & & & & & $23-24^{\circ}$, BP, tight \\
\hline $205-206$ & & & $\mathbf{x}$ & & & & & & \\
\hline $206-207$ & & & $?$ & $\mathbf{x}$ & & & & & \\
\hline $207.2-208.2$ & & 2 & $\mathbf{x}$ & $\mathbf{x}$ & $\mathbf{x}$ & & & & $27^{\circ}$, BP, light; $39^{\circ}$, high angle fracture, tight \\
\hline $210.2-211.2$ & & $>10$ & $?$ & & & & & & $\begin{array}{l}>10 \text { fracture surfaces, prodominantly BP that } \\
\text { average } 30^{\circ}\end{array}$ \\
\hline $212-213$ & & & ? & & $\mathbf{x}$ & & & & \\
\hline $215-216$ & & & $?$ & & & & & & \\
\hline $216-217$ & & & $\mathbf{x}$ & $\mathbf{x}$ & & & & & 3 \\
\hline 217.218 & & & $?$ & & $\mathbf{x}$ & & & & $\dot{U}$ \\
\hline $218-219$ & & & $?$ & & & & & & \$ \\
\hline $219-220$ & & & & $\mathbf{s}$ & & & & & \\
\hline $221-222$ & & & $\mathbf{x}$ & & & & & & \\
\hline $222-223$ & & & $\mathbf{x}$ & $\mathbf{s}$ & & & & & \\
\hline $223.1-224.1$ & & 4 & ? & $\mathbf{x}$ & $\mathbf{x}$ & & & & $22-25^{\circ}$. BP, light \\
\hline $225-226$ & & & $\mathrm{x}$ & $\mathbf{x}$ & & & & & \\
\hline $226.1-227.1$ & & 2 & & $\mathbf{x}$ & & & & & $20^{\circ}$, BP, open and tight \\
\hline $228.1-229.1$ & & 4 & $\mathbf{x}$ & & $\mathbf{x}$ & $\mathbf{x}$ & & & $20-25^{\circ}$, BP, open to tight \\
\hline $229.1 \cdot 230.1$ & & 3 & & $\mathrm{x}$ & & $\mathbf{x}$ & & & 23-28', BP, al. open to open \\
\hline $231.1-232.1$ & & 5 & $\mathbf{x}$ & $\mathbf{x}$ & & & & & $20-25^{\circ}$. BP, sl. open to tight \\
\hline 232.1 .233 .1 & & 5 & $?$ & $\mathbf{S}$ & & & & & $\begin{array}{l}\text { Low angle fracture, sl. open: } 20-23^{\circ} \text {. BP, sl. } \\
\text { open to light }\end{array}$ \\
\hline 233.234 & & & $\mathbf{x}$ & $\mathbf{x}$ & $\mathbf{x}$ & & & & \\
\hline $234 . \mathrm{i} \cdot 235.1$ & & 2 & & $\mathrm{x}$ & & & & & 25-2: , BP, tighl \\
\hline $235.1-236.1$ & & 3 & $\mathbf{x}$ & $\mathbf{x}$ & & & & & $20^{\circ}$, BP, open and tight \\
\hline $239-240$ & & & & $\mathbf{s}$ & & $\mathbf{x}$ & & & \\
\hline 249.251 & & & $\mathbf{x}$ & $\mathbf{x}$ & & $\mathbf{x}$ & & & \\
\hline $257.0-258.0$ & & 2 & & $\mathbf{s}$ & $\mathbf{x}$ & & & $\mathbf{S}$ & $21^{\circ}$, BP, tight; $40^{\circ}$, high angle fructure, tighi \\
\hline $259-260$ & & & & $\mathbf{x}$ & & & & & \\
\hline TM⿻or & & & & & & & & & \\
\hline$*$ & & & & & & & & & - \\
\hline
\end{tabular}


Table AS.1 (continued)

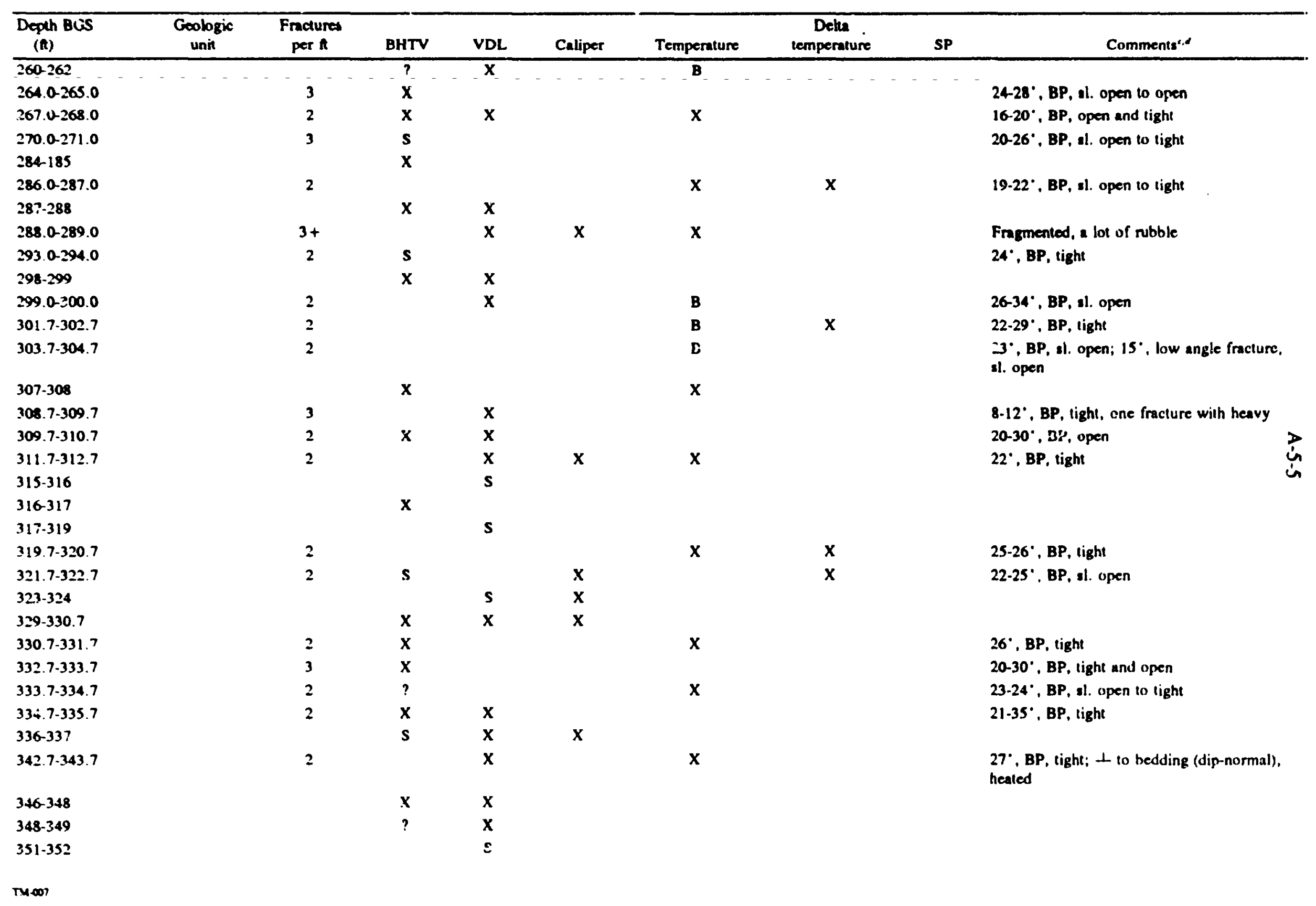


Table AS.I (continued)

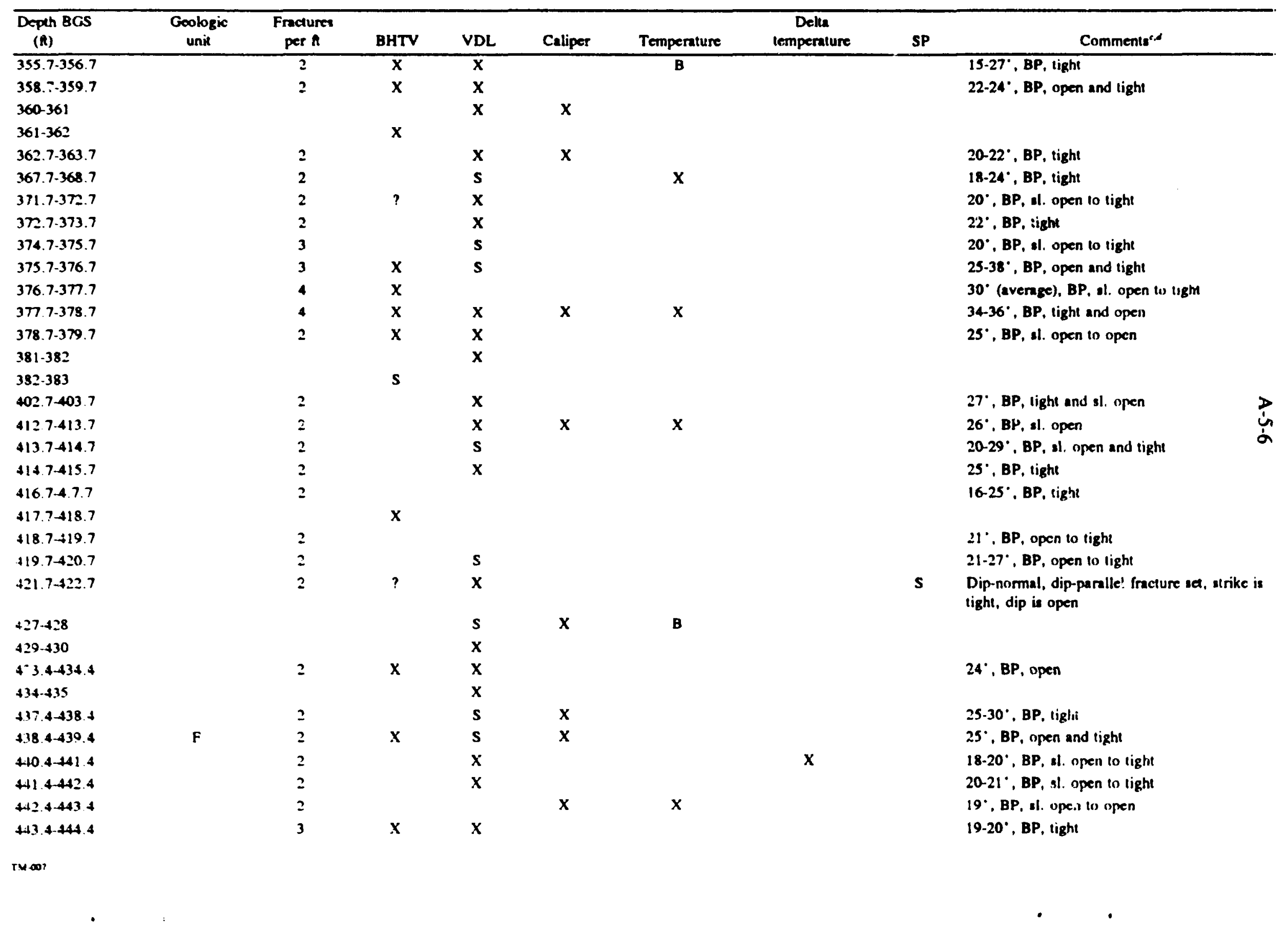


Table A5.1 (continued)

\begin{tabular}{|c|c|c|c|c|c|c|c|c|c|}
\hline $\begin{array}{l}\text { Depeh BGS } \\
\text { (A) }\end{array}$ & $\begin{array}{c}\text { Geologic } \\
\text { unit }\end{array}$ & $\begin{array}{c}\text { Fractures } \\
\text { pet } \mathrm{f}\end{array}$ & BHTV & VDL & Caliper & Temperature & $\begin{array}{c}\text { Delta } \\
\text { temperature }\end{array}$ & $\mathbf{S P}$ & Commenis ${ }^{c, d}$ \\
\hline $452-451$ & & & $\mathbf{x}$ & $x$ & & & & & \\
\hline $451-45:$ & & & & $\mathbf{x}$ & & & & & \\
\hline 452.4453 .4 & & 2 & $?$ & & $x$ & & $\mathbf{x}$ & & $23-26^{\circ}$, BP, light \\
\hline $455-456$ & & & $\mathbf{x}$ & $\mathbf{x}$ & & & & & \\
\hline $457.4-458.4$ & & 2 & $\mathbf{x}$ & $\mathbf{x}$ & & & & & $22^{\circ}, \mathrm{BP}$, tight \\
\hline $453 .-459.4$ & & 3 & $\mathbf{x}$ & $\mathbf{x}$ & & & & & $22-30^{\circ}$, BP, light \\
\hline $457.4-460.4$ & & 2 & $\mathbf{x}$ & $\mathbf{x}$ & & & & $\mathbf{s}$ & $25^{\circ}, \mathrm{BP}$, tight \\
\hline $461-462$ & $\mathbf{E}$ & & & $\mathbf{X}$ & & & & & \\
\hline $463-464$ & & & $\mathbf{x}$ & & & B & $\mathbf{x}$ & & \\
\hline $46+465$ & & & & $\mathbf{x}$ & & & & & \\
\hline $465-466$ & & & $\mathbf{x}$ & & & & $\mathbf{x}$ & & \\
\hline$+600-467$ & & & & $\mathbf{x}$ & $\mathbf{x}$ & $\mathbf{x}$ & & & \\
\hline $467-468$ & & & & $\mathbf{x}$ & & & & & \\
\hline $472.4-473.4$ & & 2 & $\mathbf{x}$ & & & & $x$ & & $20^{\circ}$, BP, sl. open to tight \\
\hline $47-478$ & & & $?$ & & $\mathbf{x}$ & & & & \\
\hline $481,4-4824$ & & 2 & & & & B & $\mathbf{x}$ & & $23-40^{\circ}$, BP, nl. open to tight \\
\hline $483.4-484.4$ & & 2 & & & $\mathbf{x}$ & & & & $\begin{array}{l}\text { Dip-normal, dip-iarallel fracture set, strike is } \\
\text { tight, dip is oper }\end{array}$ \\
\hline $484.4+85.4$ & & 2 & +++ & & & $\mathbf{B}$ & & & $30^{\circ}$, BP, tight \\
\hline $4854-486.4$ & & 2 & & & & & & & $30-40^{\circ}$, Bre, tight \\
\hline $4864-487.4$ & & 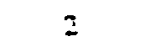 & & & & & & & $35-40^{\circ}$, PP, light \\
\hline $488.4-489.4$ & & 3 & & & & & & & $10-26^{\circ}, \mathrm{B} \cdot$, sl. open to tight \\
\hline
\end{tabular}

- Cnly those wepth intervals obtained from the goologist's ogs have an accuracy of $0.1 \mathrm{ft}$. Depth inlenials from other logs were not as accurate.

'From geologist's log.

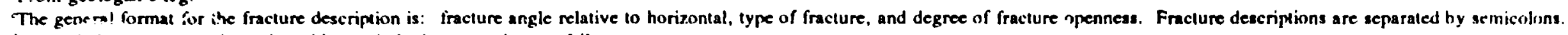
Nis deviation suivey per iostrad on this corehole due to equipment failure.

LEGE YD

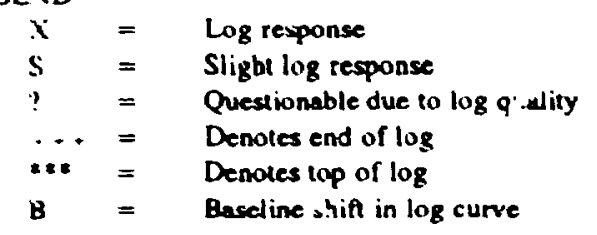

1. BP - Bodding plane 'racture; fracture that necurs along the plane of bodding, which typically ranged from $25-40^{\circ}$ as measured purpendicular to the long axis of the core. 
Table A5.1 (continued)

2. Dip-eornel frecture - Any frecture the is perpendicular to bedding; typically either parallel or perpendicular to mrike.

Dip-paralled frecture - Any frecture the is parallel to bedding.

Low angle frecture - As moasured perpendicular to the long exis of the core, a low angle frecture is generally an an angle leas than bedding.

High angle fracture - At measurod perpendicular to the long axis of the core, a high angle fracture is generally at an angle greater than bedding.

6. $\perp$ - A dip-normal fracture; perpendicular to boddisig. 


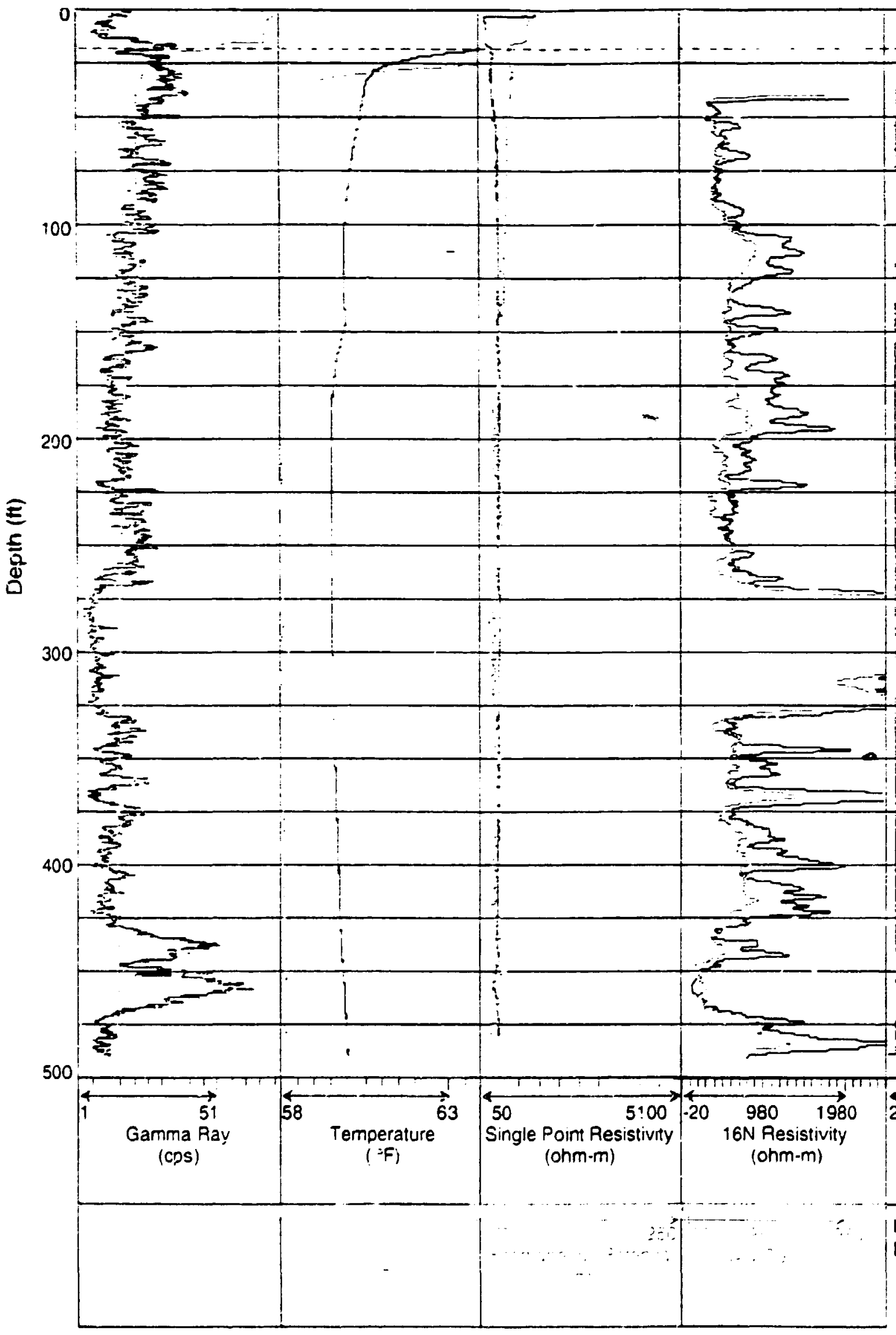

Corehoie total deptr $=19$

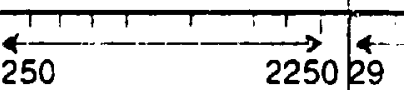

4.P, Density icps'

Notes:

Depths shown are frum grol - . - Surface casing dep Static water level at ]2 Packer test interval 


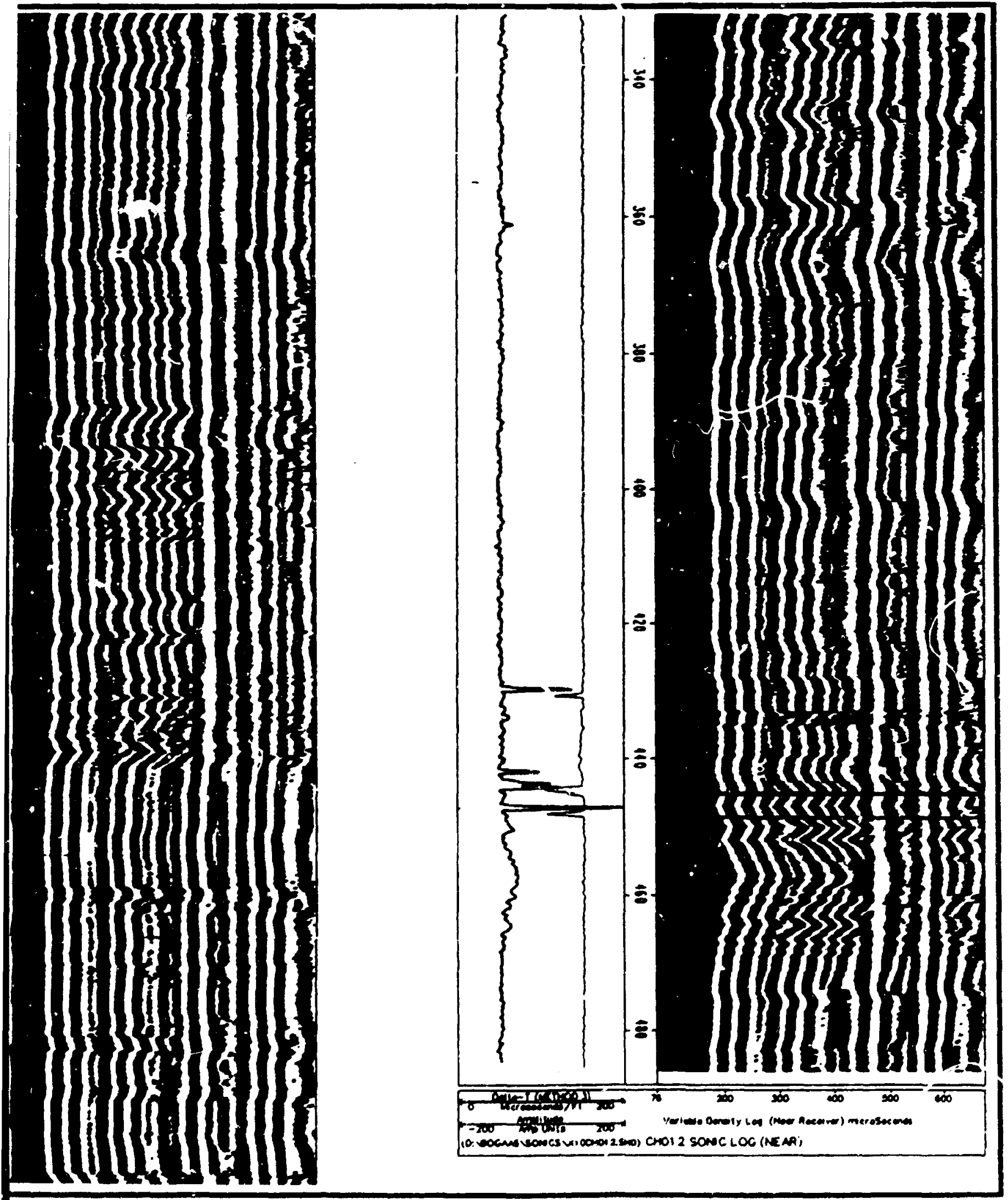

Fig. A5.2. CH012 vartable density (acoustic) log. 
ORNL DWO 9114424

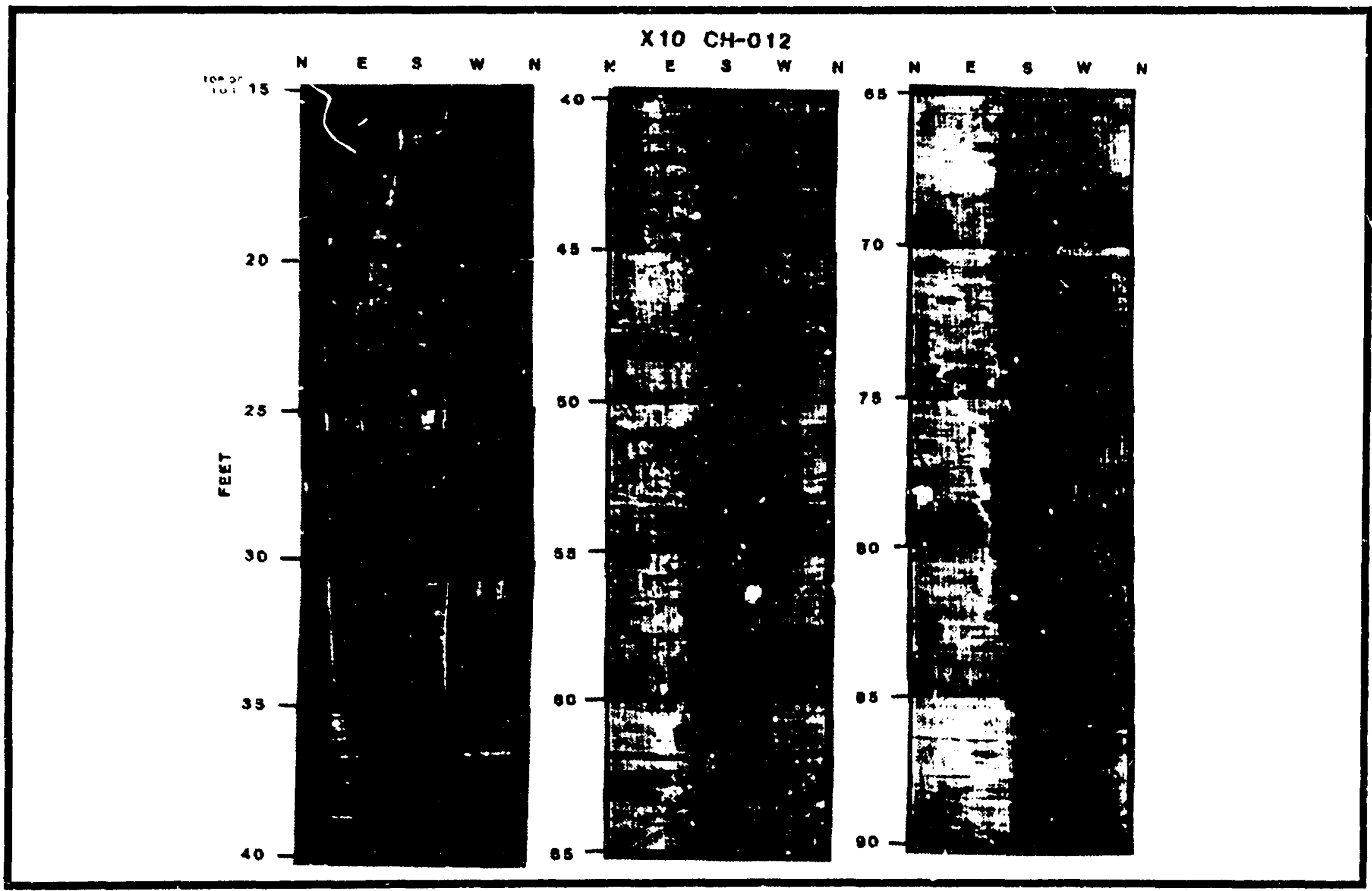




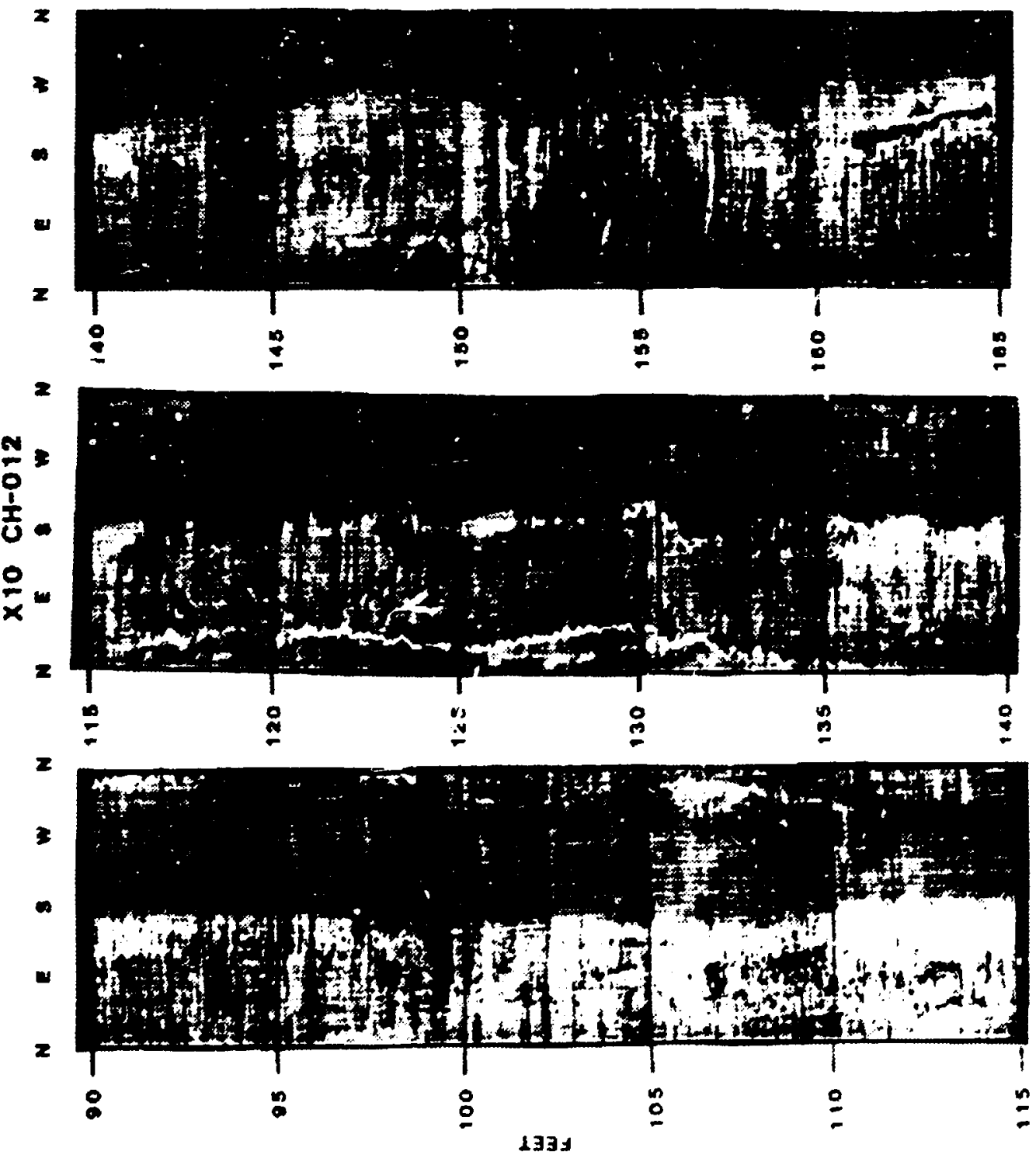


A-.5-13

8
$\vdots$
0
0
3
0
$\frac{7}{5}$
0
0
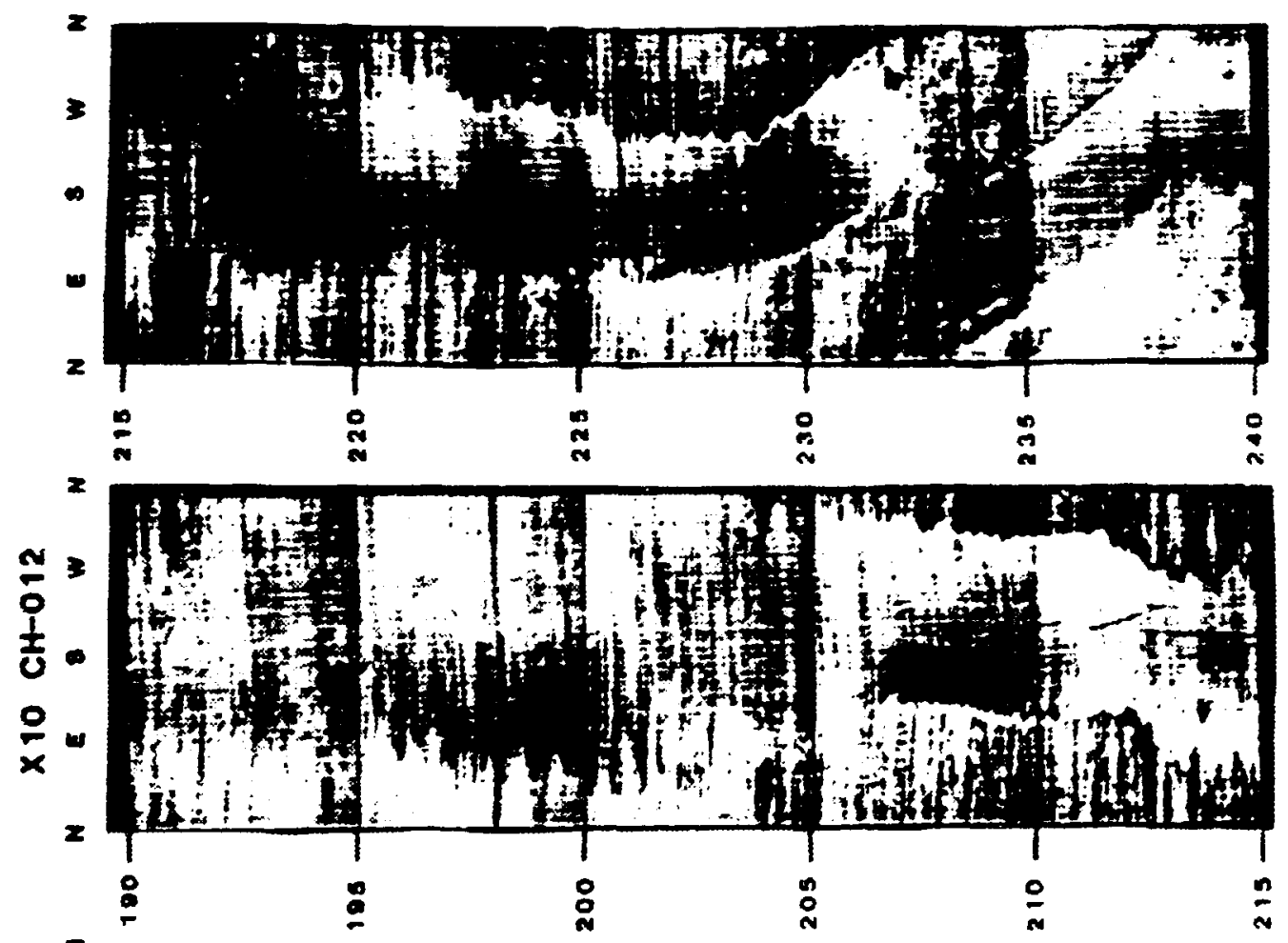

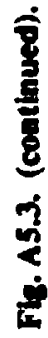

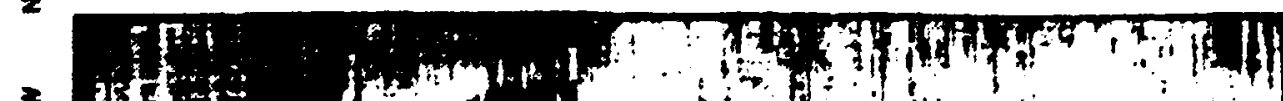

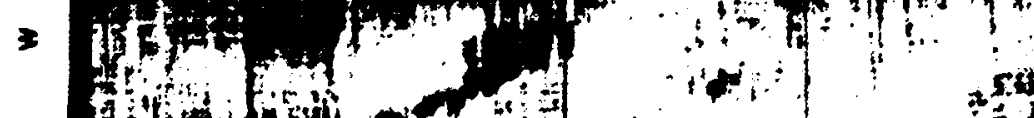

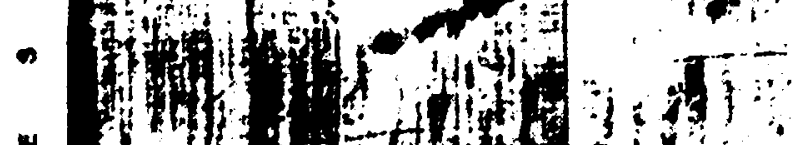

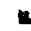

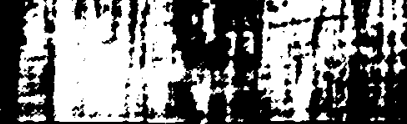

2

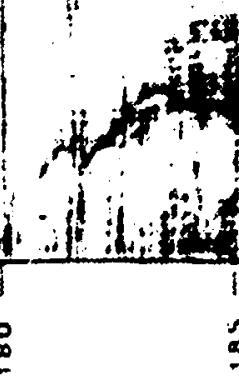

L37. 


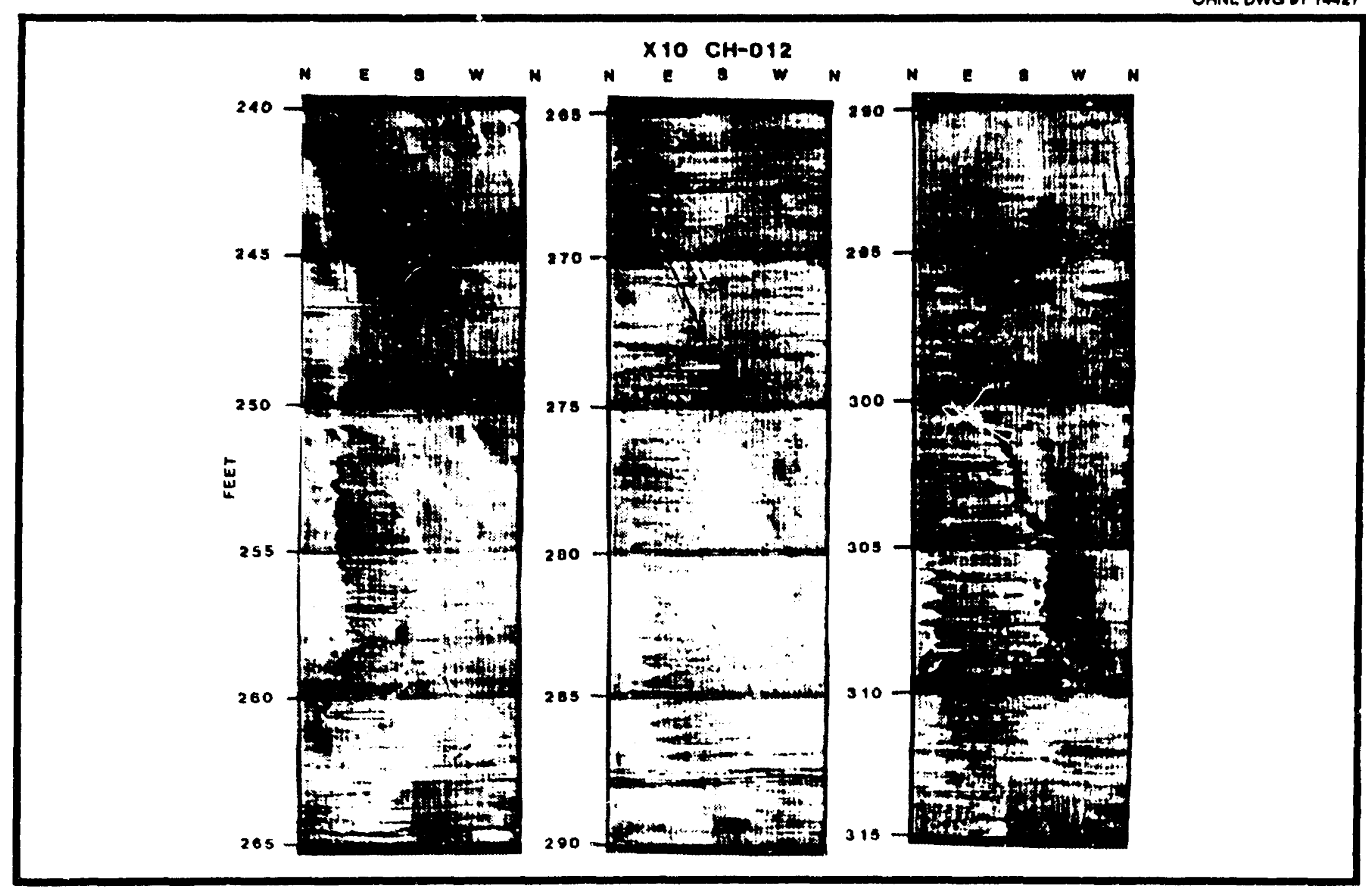

F4. A5.3. (continued). 


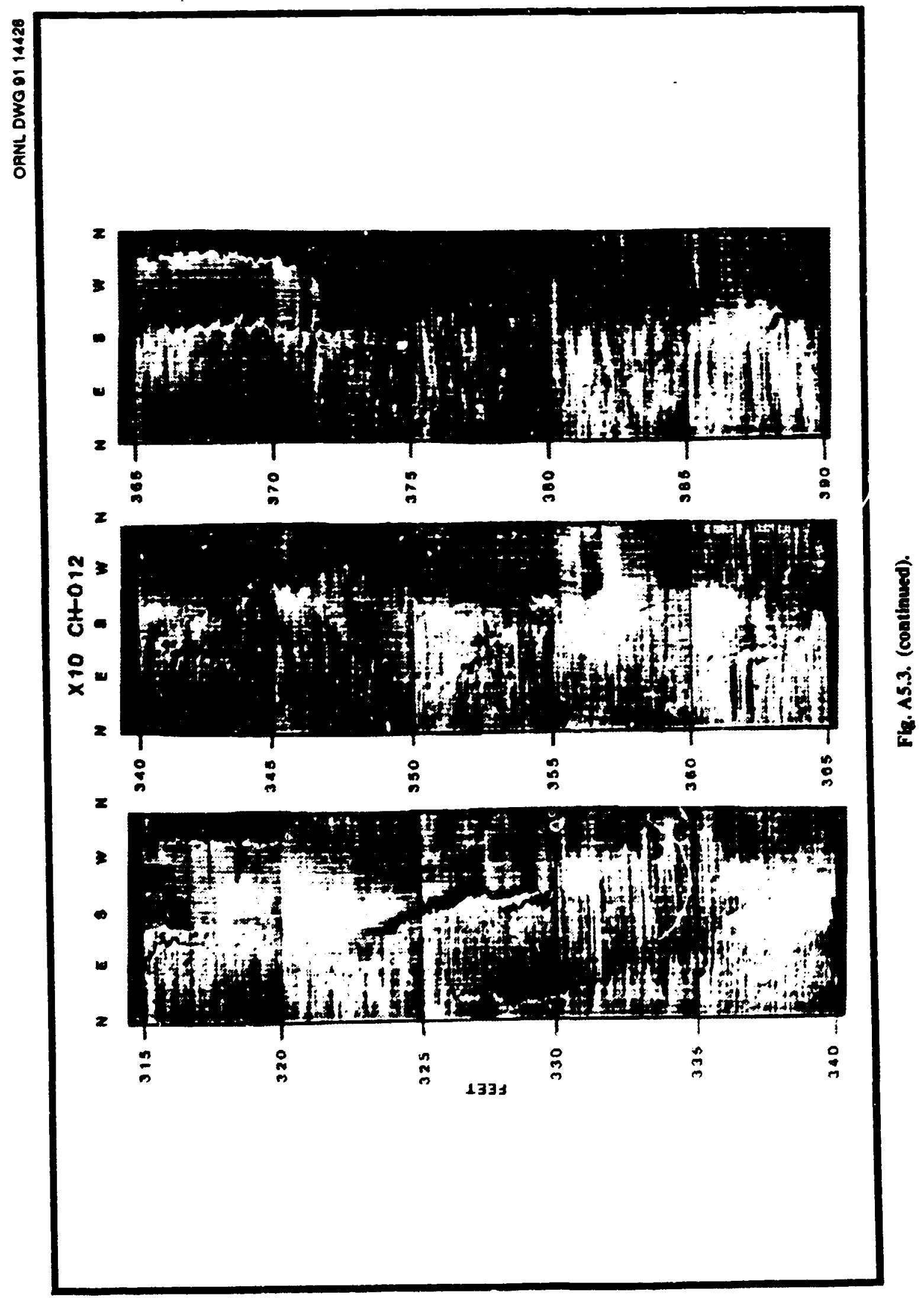



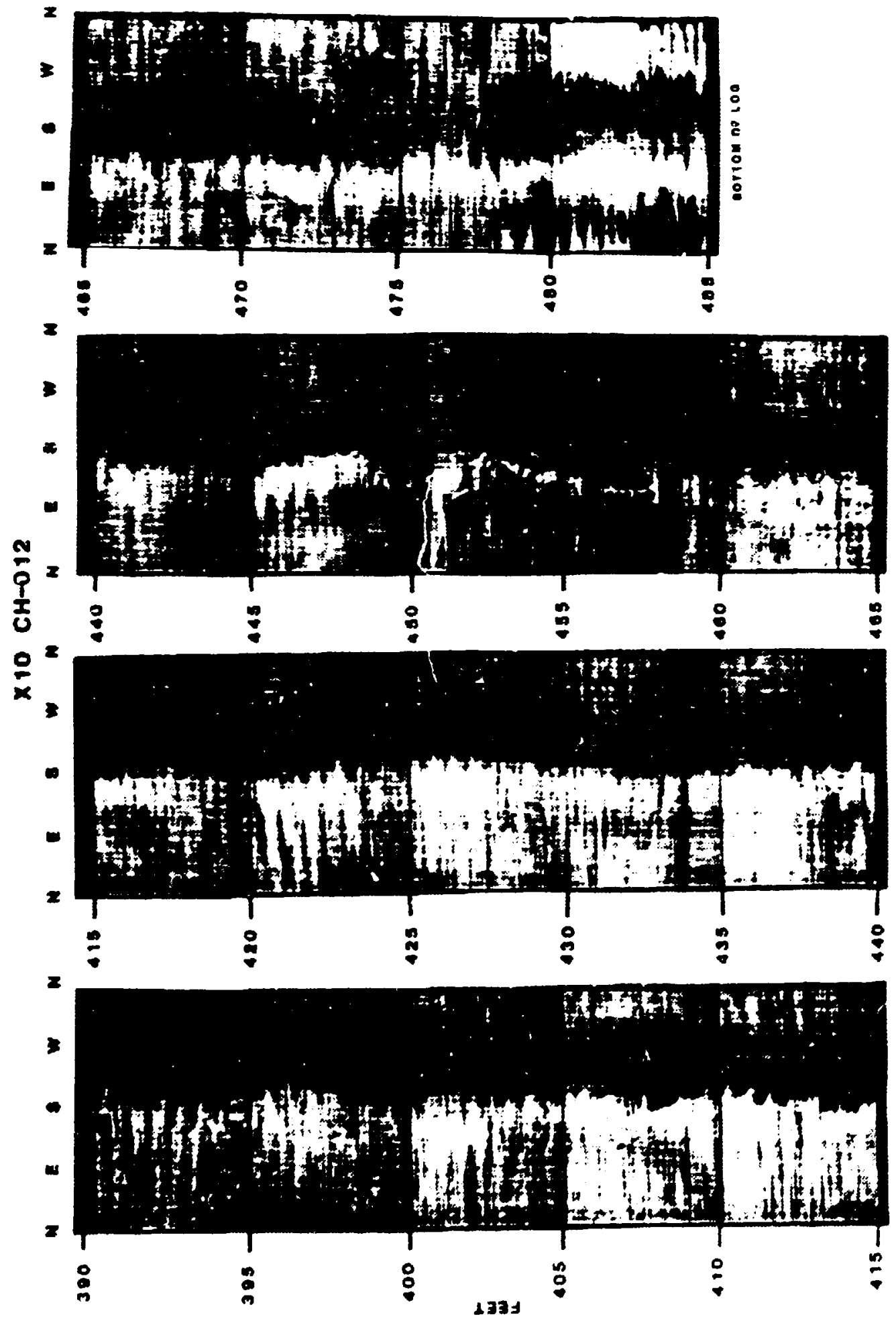


\section{ORNL Borehole Flowmeter Survey}

Well $\mathrm{CH}$ 12, Ambient survey $11 / 6 \& 7 / 1991$

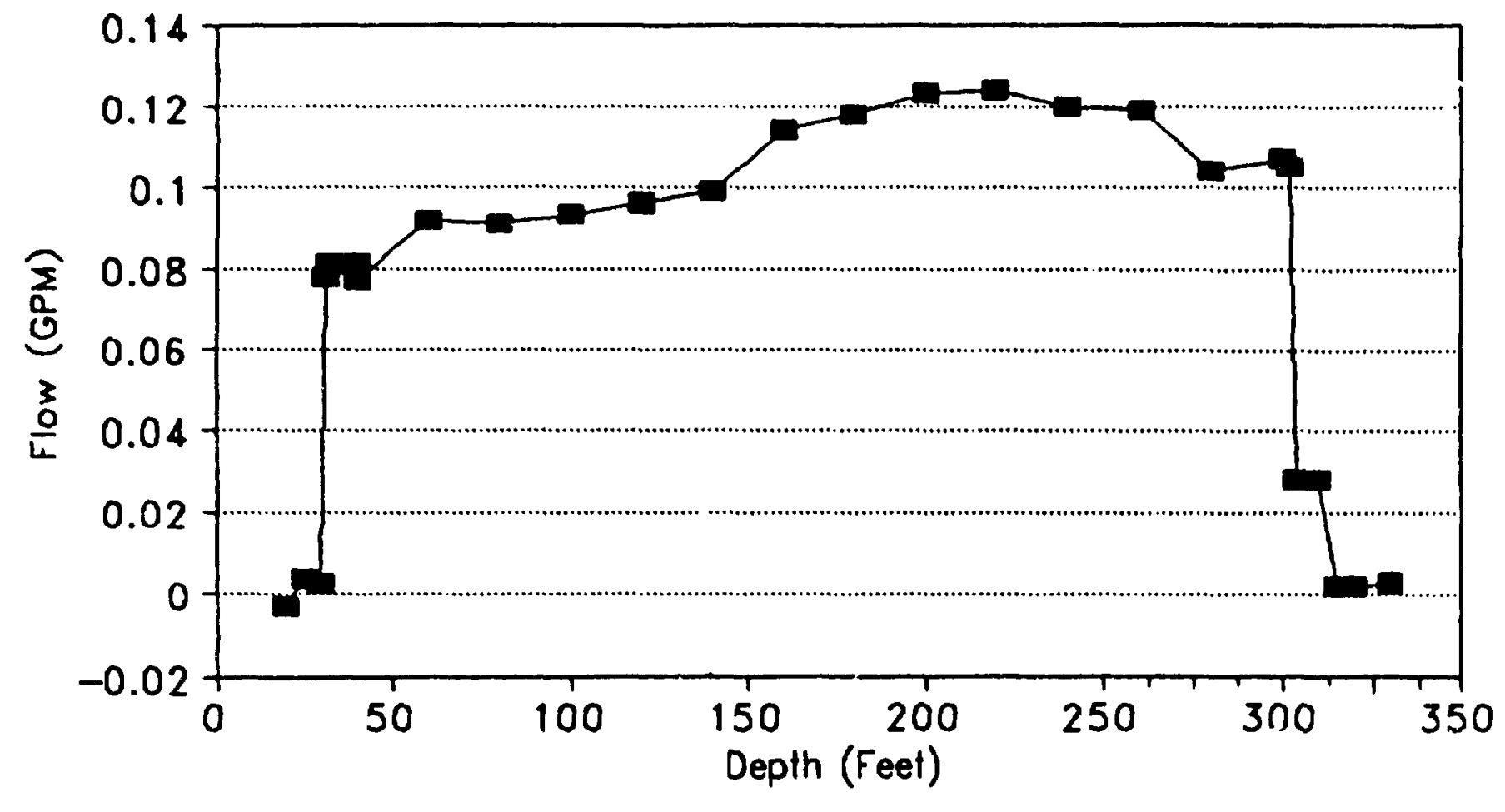

$\rightarrow$ - Ambient A \& B

Fig. A5.4. CH012 ORNL borehole blowmeter survey. 
ORNL Borehole nowmeter survey CH012, ambient survey November 6-7, 1991

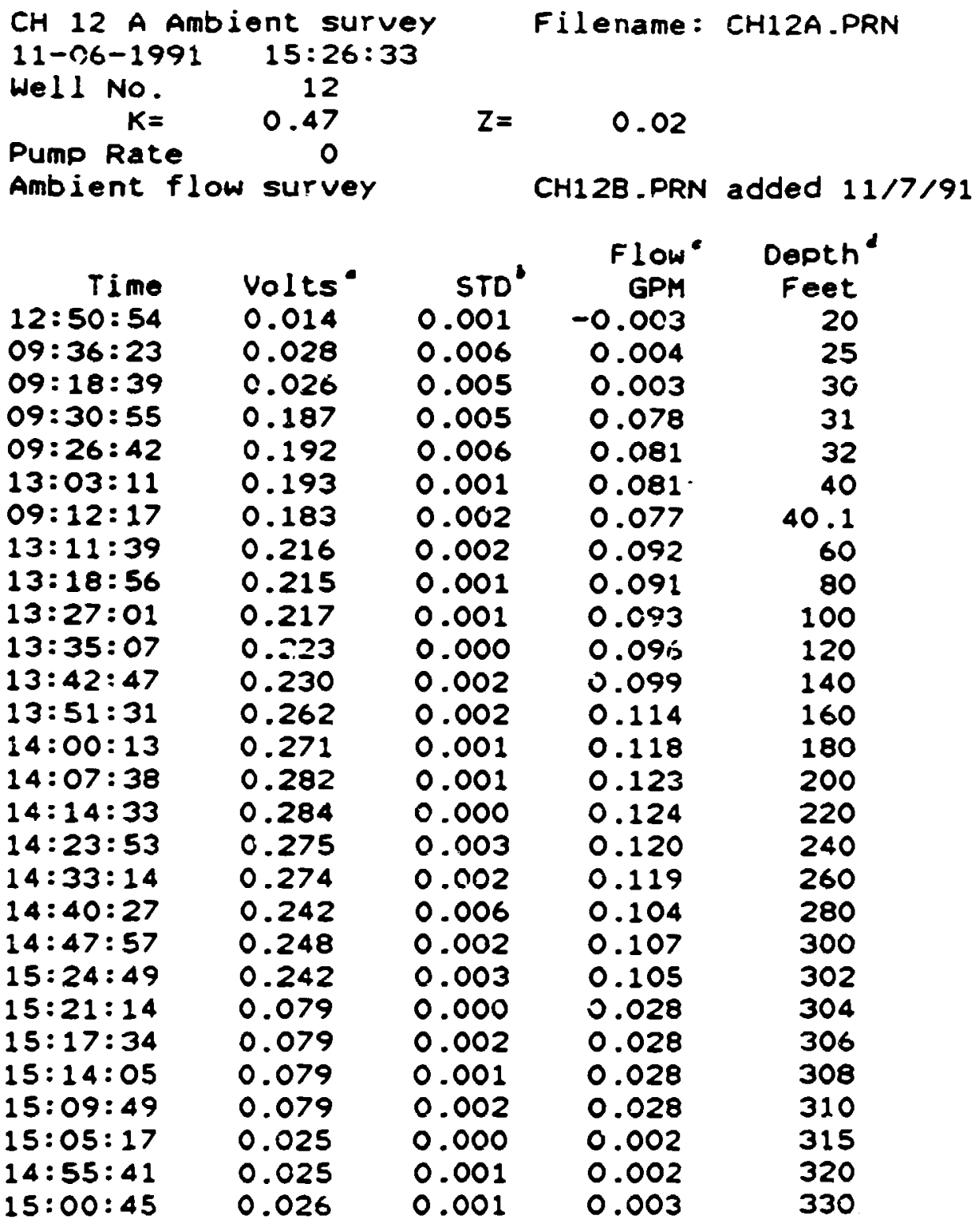

-Volts column is anaiog signal from the flowmeter.

'STD column is standard deviation of the analog signal.

Ambient surveys measure natural flow (no injection) in the corehole. A plus sign means flow up the hole. Flow rate is gallons per minute.

Depths are measured from top of inner casing. 
ATTACHMENT 6

FT10-GEOPHYSICAL AND GEOLOGIC DATA

R:ITMTMNO12 
Table A6.1. Summary of fractures identified in corehole FT10

\begin{tabular}{|c|c|c|c|c|c|c|c|c|c|c|}
\hline $\begin{array}{l}\text { Depth BGS } \\
\text { (in) }\end{array}$ & $\begin{array}{l}\text { Goologic } \\
\text { unit }\end{array}$ & $\begin{array}{c}\text { Fnatures } \\
\text { per } n\end{array}$ & BHTV & VDL & Caliper & Temperalure & $\begin{array}{c}\text { Delk } \\
\text { temperature }\end{array}$ & SP & $\begin{array}{l}\text { Devintion } \\
\text { eurvey* }\end{array}$ & Comments \\
\hline $30-31$ & D & & & & & $\mathbf{x}$ & & & & $\begin{array}{l}\text { Ceologin's los } \\
\text { not available }\end{array}$ \\
\hline 33-34 & & & & & & $\mathbf{x}$ & & & & \\
\hline $35-36$ & & & & & & $x$ & & & & \\
\hline $40-41$ & & & & & & $x$ & & & & \\
\hline $46-47$ & & & & & & $\mathbf{x}$ & & & & \\
\hline so-si & & & & & & $\mathbf{x}$ & & & & . \\
\hline $53-54$ & & & & & & & $x$ & & & \\
\hline $67-68$ & & & & $\cdots$ & & & $\mathbf{s}$ & & & \\
\hline $78-79$ & & & & $\mathbf{x}$ & & & & & & \\
\hline $79-80$ & & & $* n$ & $\mathbf{x}$ & & $x$ & & $\mathbf{x}$ & & \\
\hline $80-81$ & & & $\mathbf{x}$ & & & & & & & \\
\hline $81-82$ & & & $\mathbf{s}$ & & & & & & & \\
\hline $82-83$ & & & $\mathbf{x}$ & & & & & & & \\
\hline 83-8: & & & $x$ & & & & & & & \\
\hline 8485 & & & $\mathbf{s}$ & & & & & & & \\
\hline $85-86$ & & & $\mathbf{s}$ & & $x$ & B & & & & \\
\hline $87-88$ & c & & $\mathbf{x}$ & & & & & & & \\
\hline 88-89 & & & & & $\mathbf{x}$ & & & & & \\
\hline $90-91$ & & & $\mathbf{x}$ & $\mathbf{x}$ & & & & & & \\
\hline $91-92$ & & & $x$ & $\mathbf{x}$ & & & & & & \\
\hline $93-04$ & & & & & $\mathbf{x}$ & & $x$ & & & \\
\hline $94-95$ & & & $\mathbf{x}$ & & & & & & & \\
\hline $95-96$ & & & $\mathbf{x}$ & $\mathbf{x}$ & $\cdot$ & $x$ & & & & \\
\hline $99-100$ & & & & $\mathbf{x}$ & $\mathbf{x}$ & & & & & \\
\hline $100-101$ & & & $\mathbf{x}$ & $x$ & $\mathbf{x}$ & & & & & \\
\hline $102-103$ & & & $\mathbf{x}$ & $\mathbf{x}$ & $\mathbf{x}$ & B & & $\mathbf{x}$ & & \\
\hline $103-104$ & & & & $x$ & & & & & & \\
\hline $104-105$ & & & $x$ & $\mathbf{x}$ & & $x$ & & $x$ & & \\
\hline $105-106$ & & & $x$ & $x$ & & $x$ & & & & \\
\hline $106-107$ & & & $\mathbf{x}$ & $\mathbf{x}$ & $x$ & & & & & \\
\hline $107-108$ & & & $\mathbf{x}$ & $\mathbf{x}$ & & & & & & \\
\hline $108-109$ & & & $\mathbf{x}$ & $\mathrm{x}$ & & & & & & \\
\hline
\end{tabular}


Table A6.1 (continued)

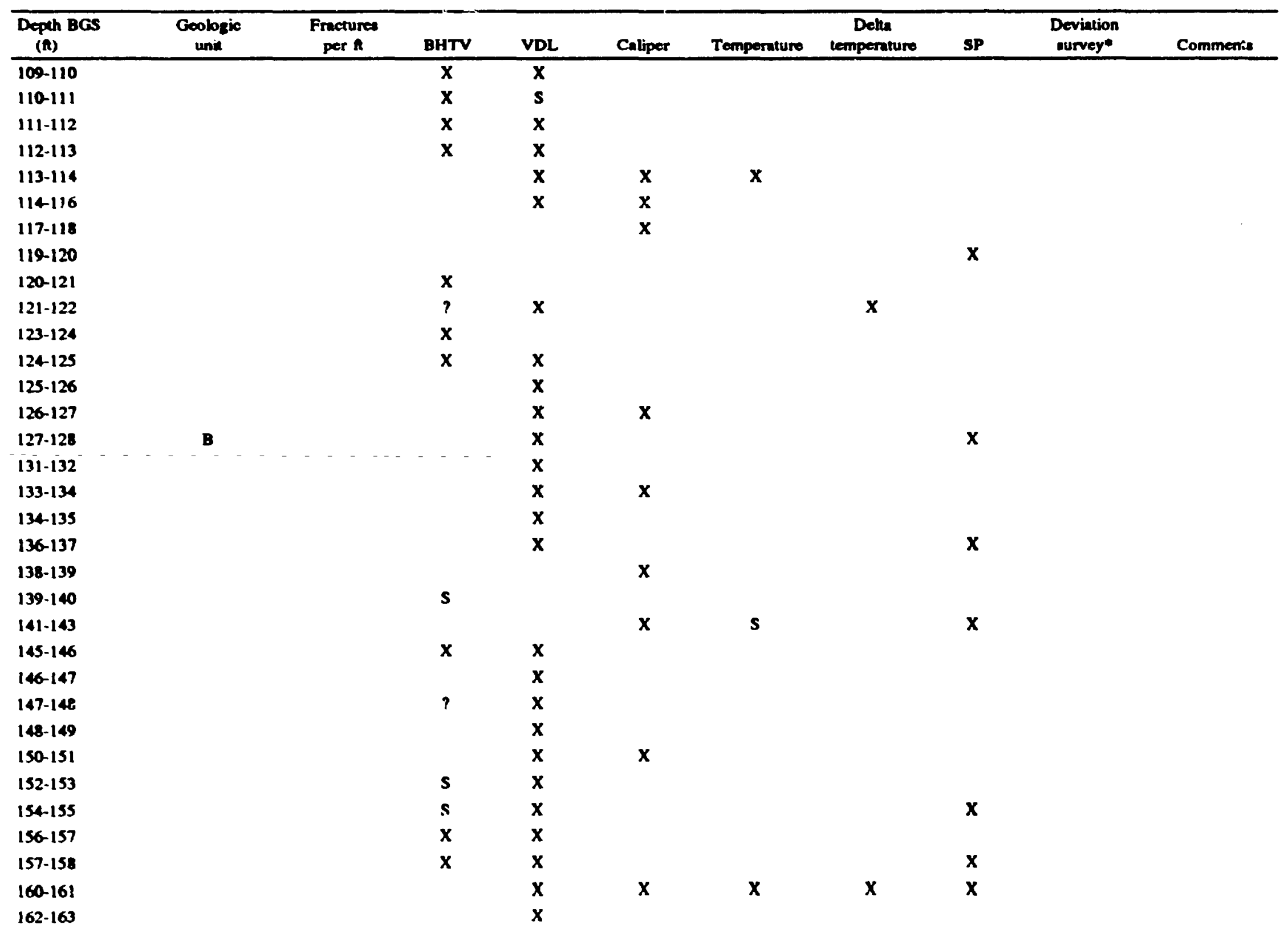




\section{A-6.}

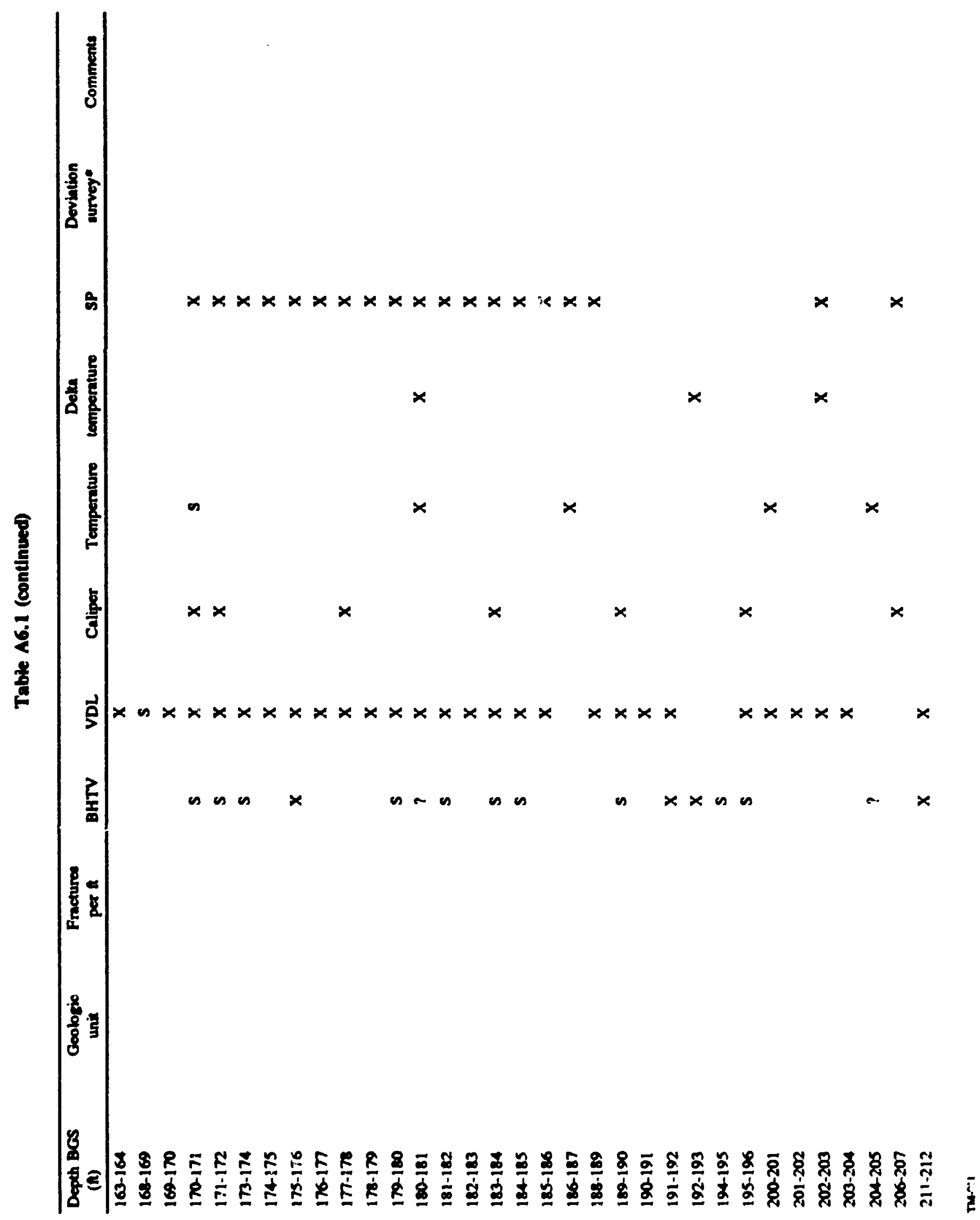




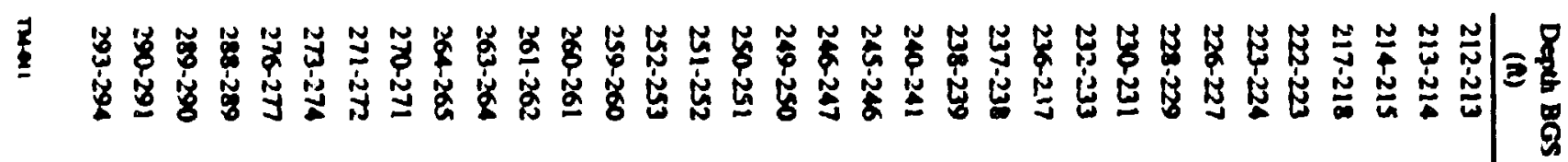

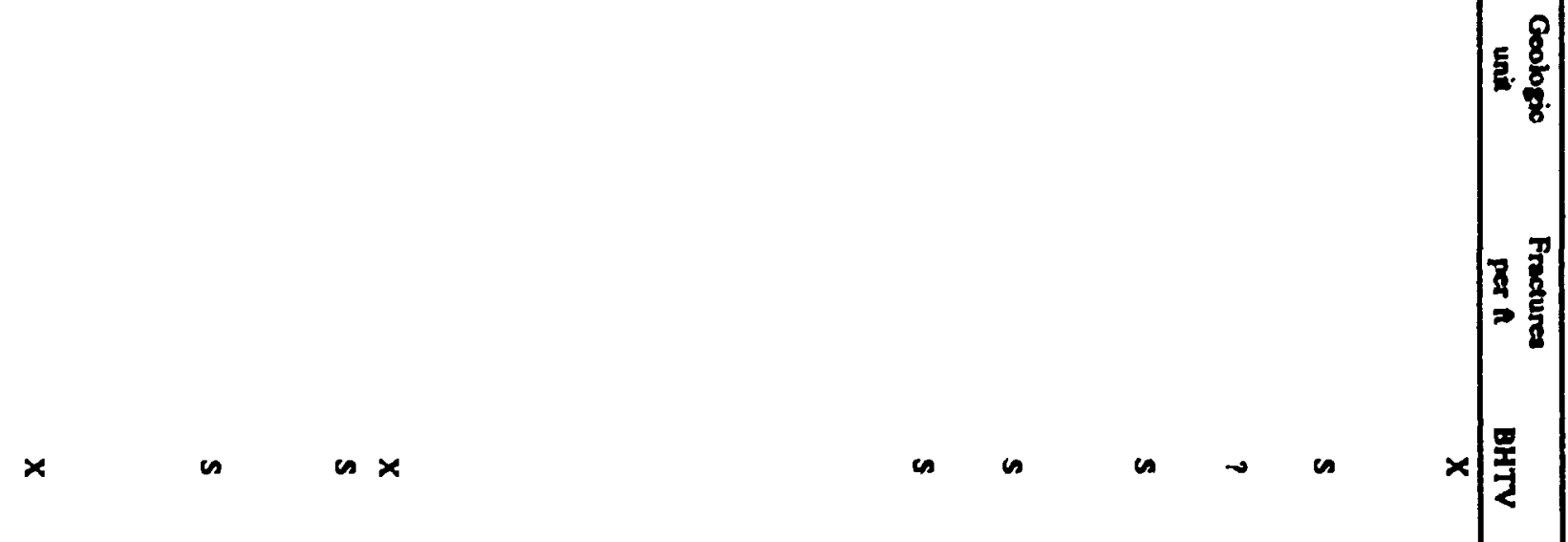

$x \times x \times x \times x \times x \times x \times x \times x \times x \times x \times x \times x \times x \times x$

$x \times x \times x \times x \times x$

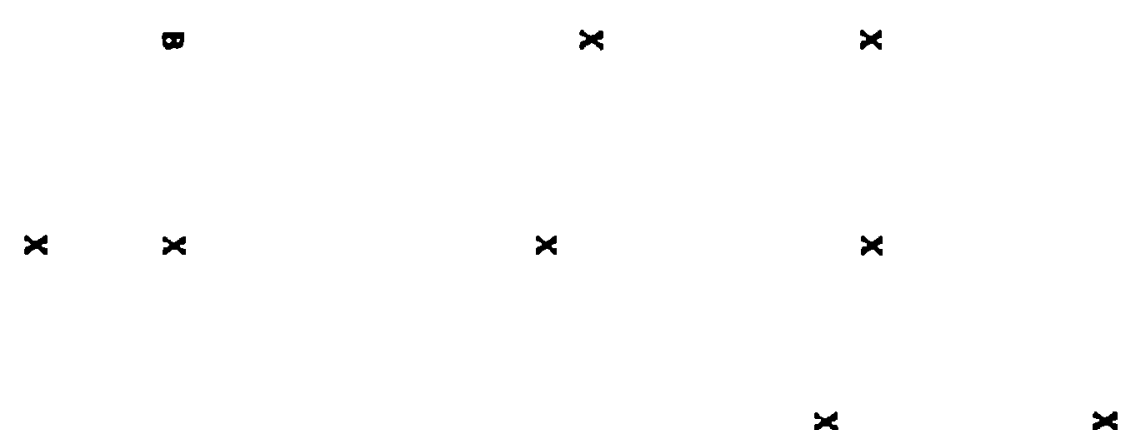

$\infty x$

$x$

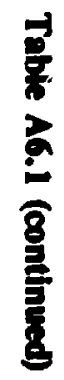




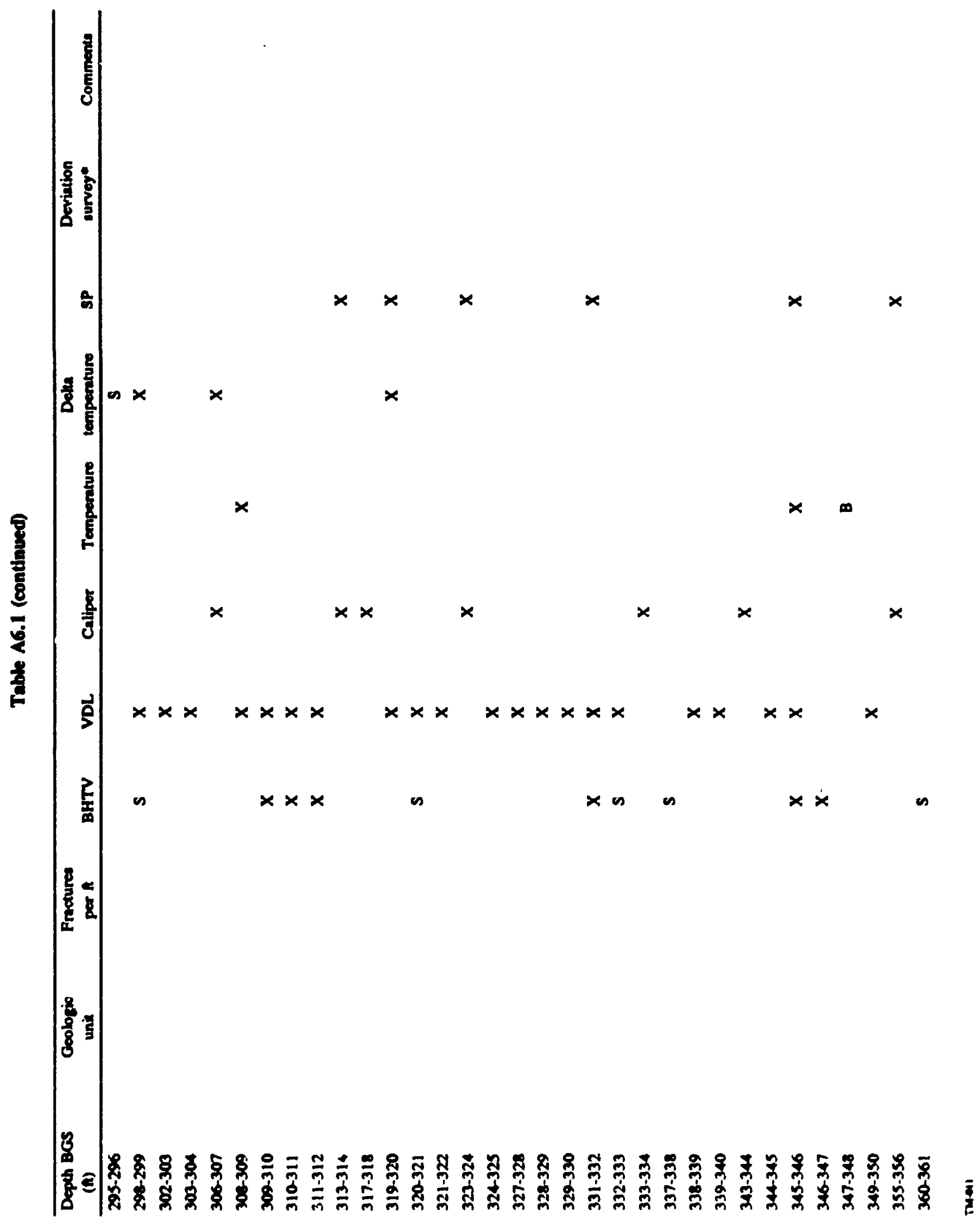


Table AG.1 (continued)

\begin{tabular}{|c|c|c|c|c|c|c|c|c|c|c|}
\hline $\begin{array}{l}\text { Depes Bas } \\
\text { (a) }\end{array}$ & $\begin{array}{c}\text { Goologic } \\
\text { unit }\end{array}$ & $\begin{array}{c}\text { Fractures } \\
\text { per in }\end{array}$ & BHTV & VDL & Caliper & Tempanture & $\begin{array}{l}\text { Della } \\
\text { canpenture }\end{array}$ & $\mathbf{s P}$ & $\begin{array}{l}\text { Dovintion } \\
\text { survey" }\end{array}$ & Comments \\
\hline $361-362$ & & & & & & $\mathbf{s}$ & & & & \\
\hline $362-363$ & & & & $\mathbf{x}$ & $\mathbf{x}$ & & $\mathbf{x}$ & & & \\
\hline $367-365$ & $\mathbf{A}$ & & $\mathbf{s}$ & & & & & & $\mathbf{s}$ & \\
\hline $370-371$ & & & & $\mathbf{x}$ & & & & & & \\
\hline $371-372$ & & & $\mathbf{s}$ & $\mathbf{x}$ & & & & & & \\
\hline $372-373$ & & & $\mathbf{s}$ & & & & & & & \\
\hline $373-374$ & & & & $\mathbf{x}$ & & & & & & \\
\hline $374-375$ & & & $\mathbf{s}$ & & $\mathbf{x}$ & & & & & \\
\hline $376-377$ & & & & & & & & $\mathbf{s}$ & & \\
\hline $381-382$ & & & & $\mathbf{x}$ & $x$ & & & & & \\
\hline $383-324$ & & & & $\mathbf{x}$ & & & & & & \\
\hline $326-397$ & & & & & $\mathbf{x}$ & & & & & \\
\hline $307-39$ & & & & $\mathbf{x}$ & & & & & ' & \\
\hline $302-390$ & & & & $x$ & & & & & & \\
\hline $395-396$ & & & $++t$ & $x$ & & & & & & \\
\hline
\end{tabular}

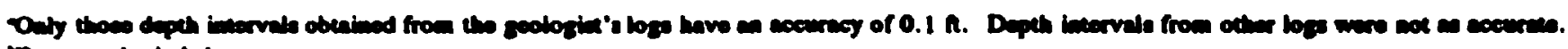

From rologicis bog.

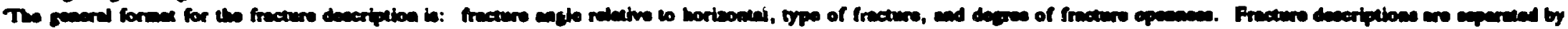
conicolone.

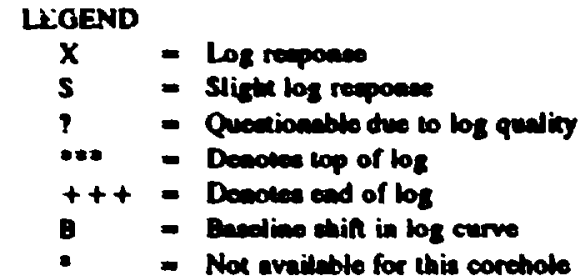









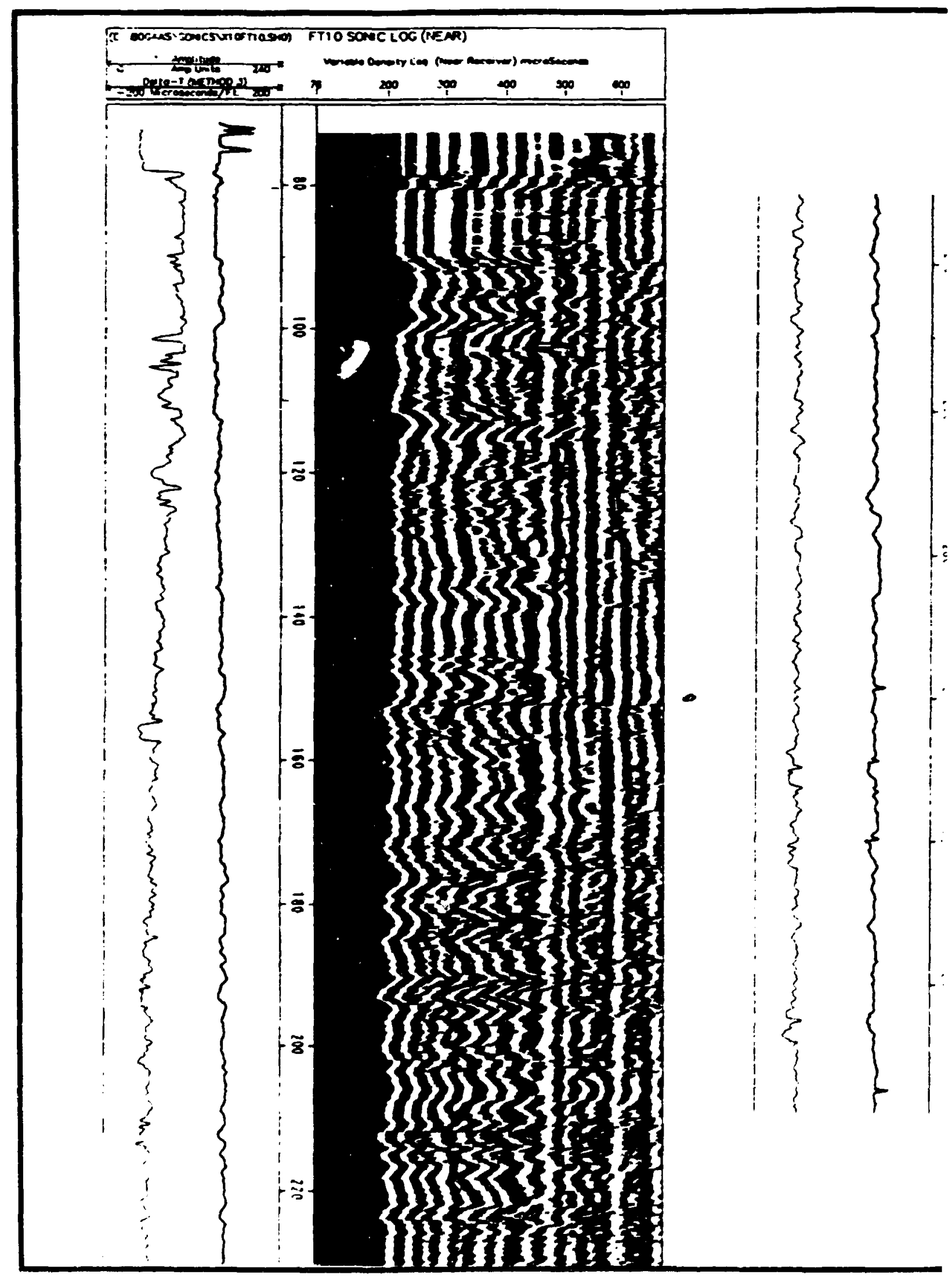



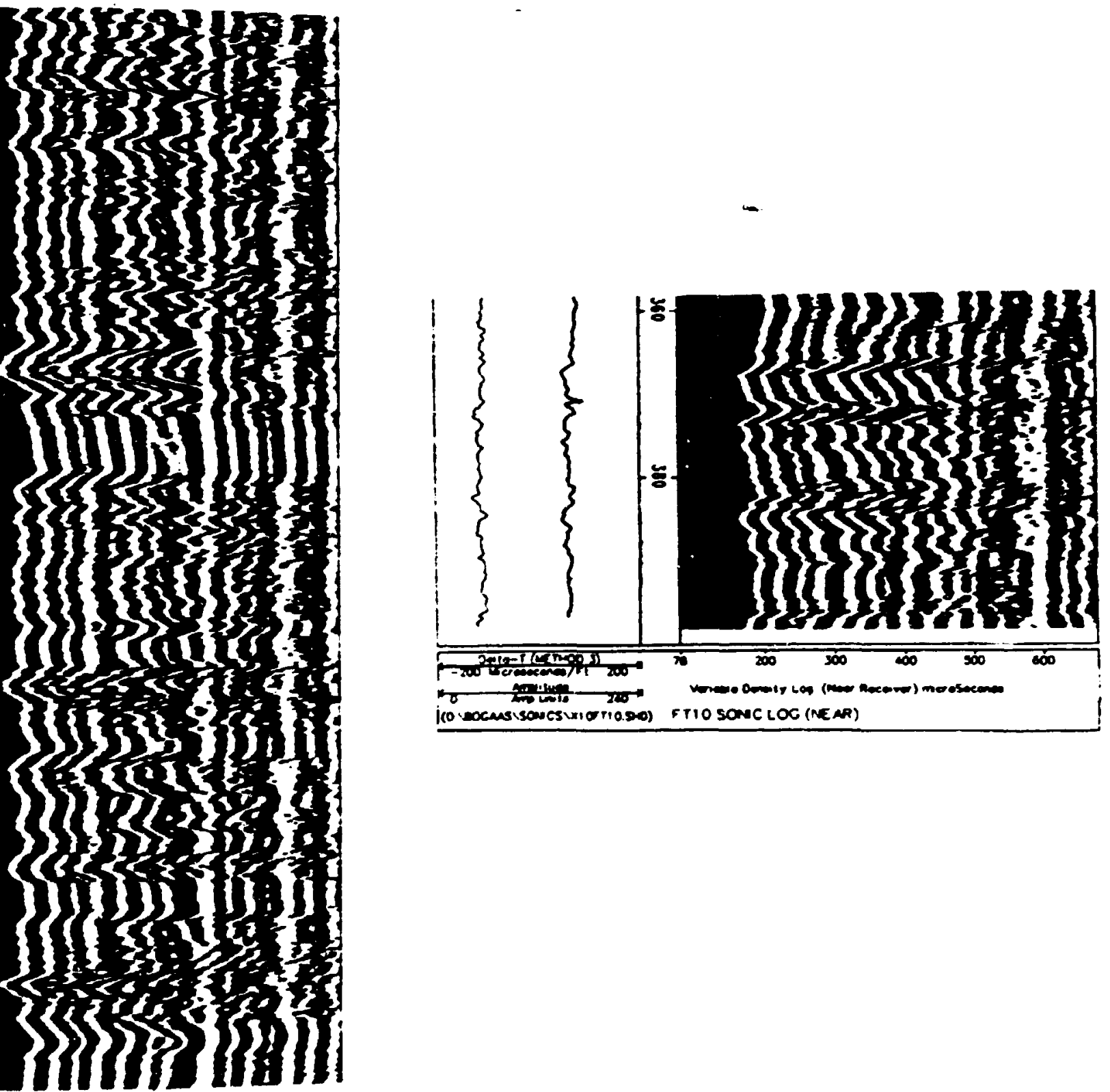

Fig. A0.2. FT10 variable density (acoustic) Jog. 


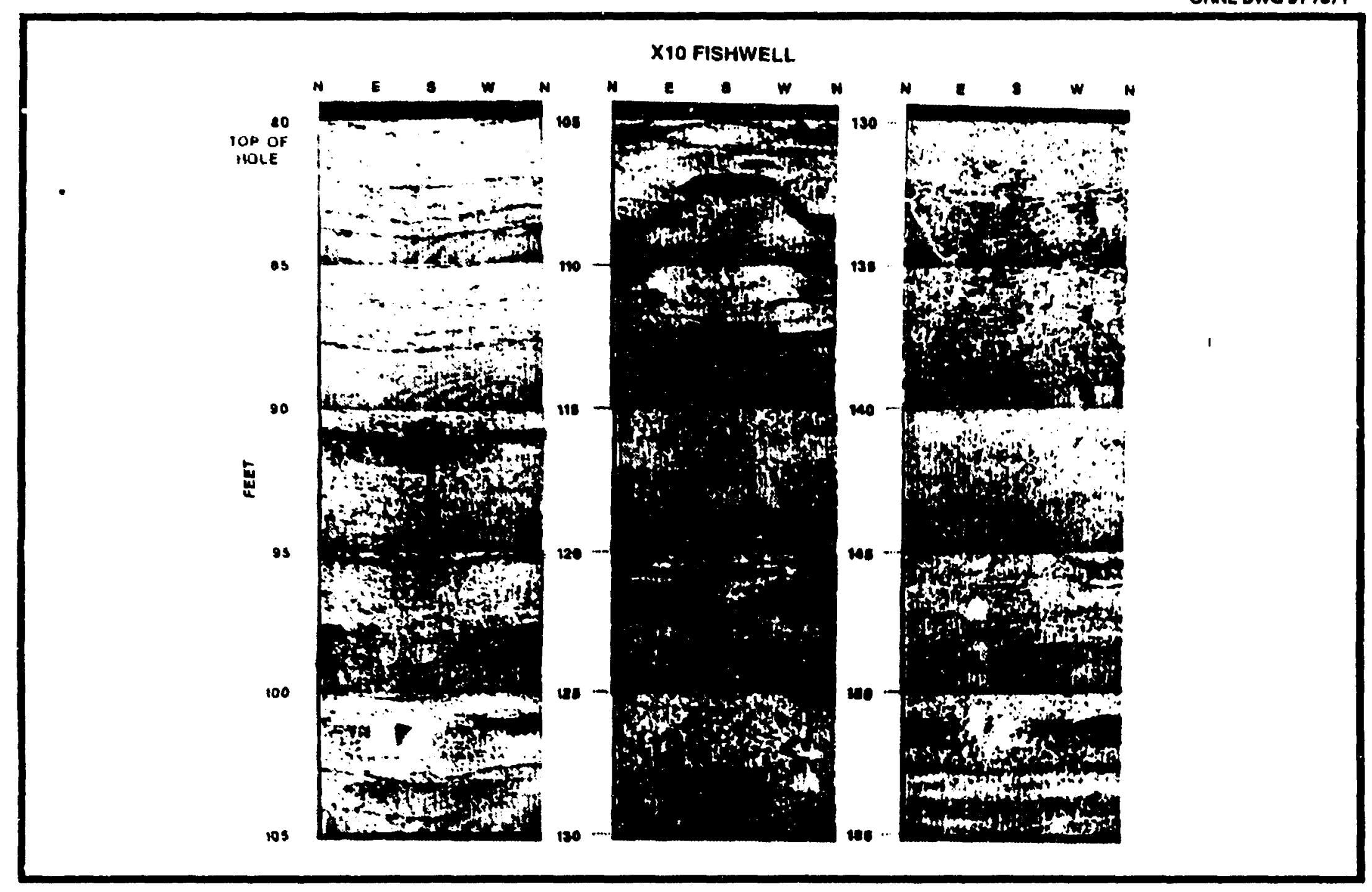

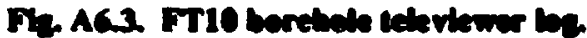




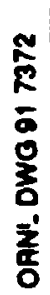
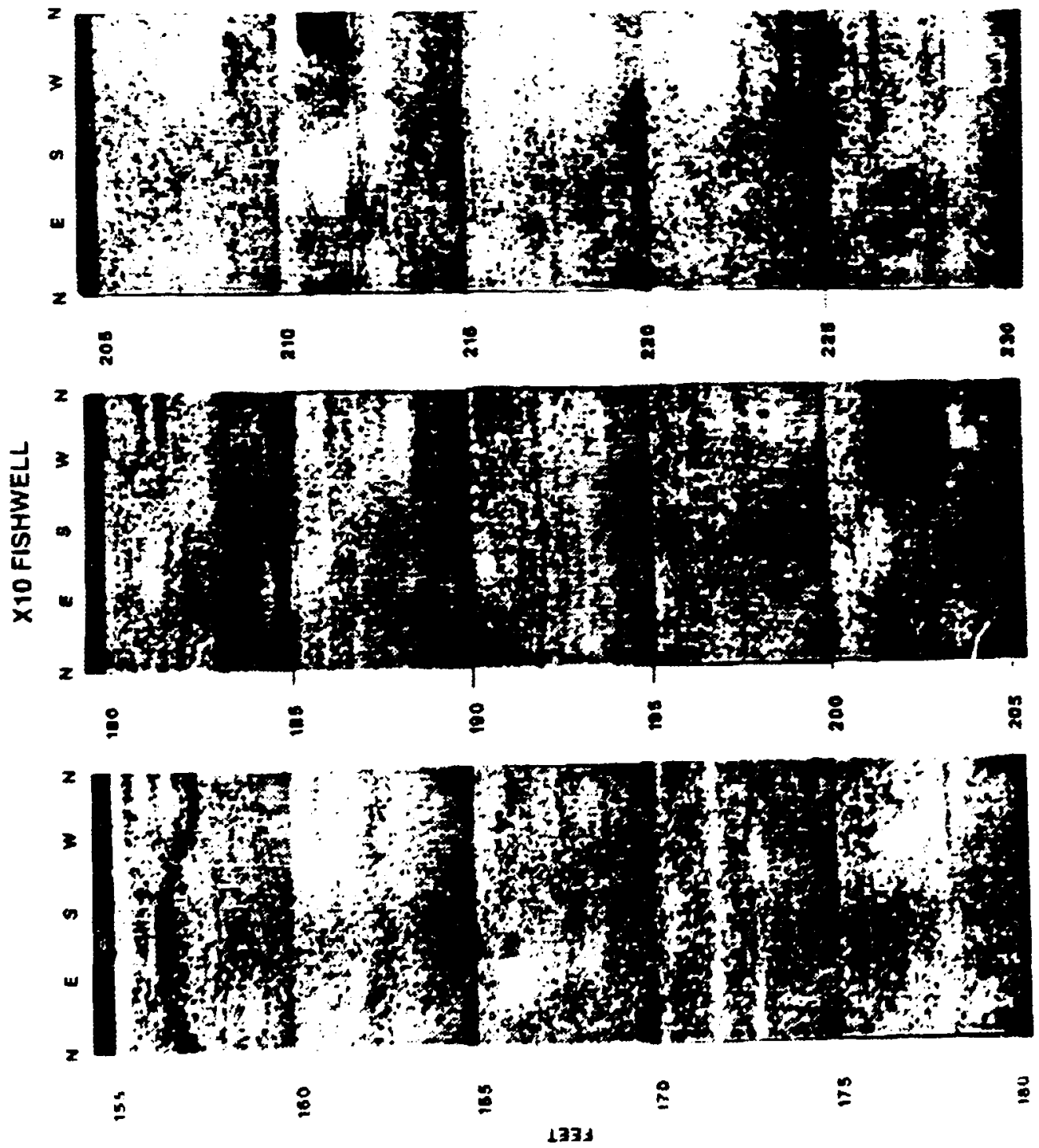


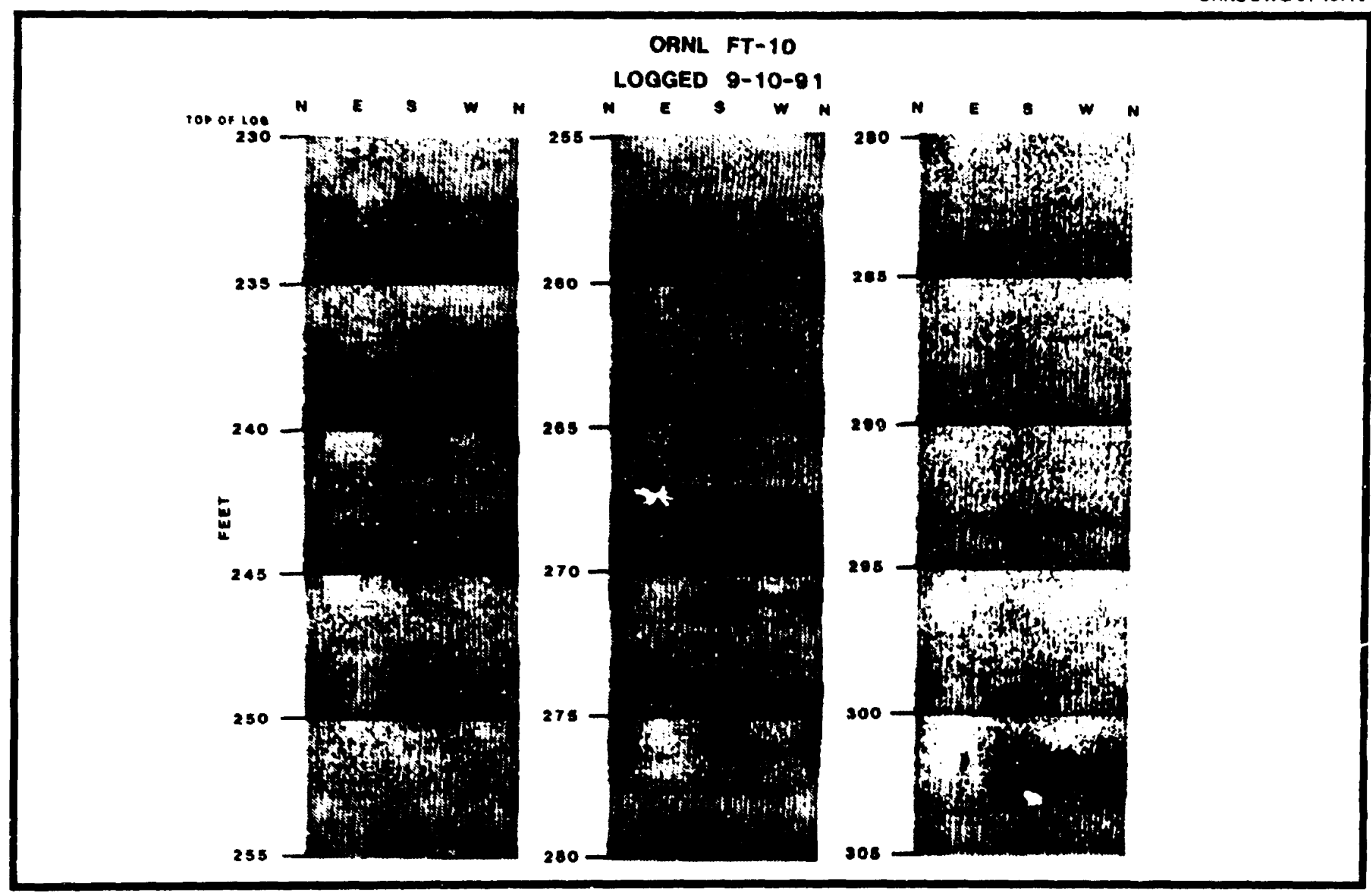

Fr. A6.3. (continued). 
OANL DWO 9115780

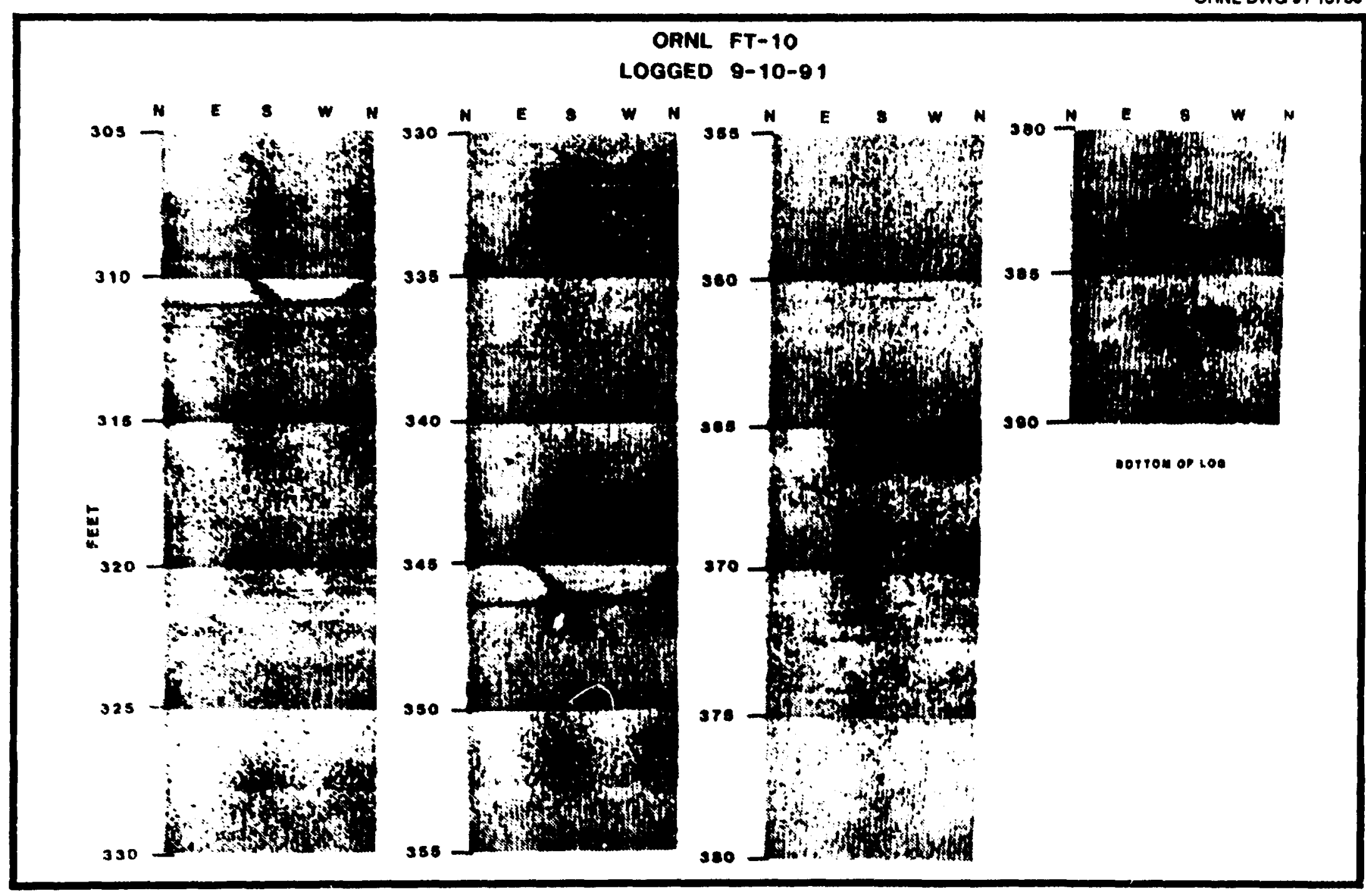

$\frac{1}{6}$

Fis. A6.3. (continued). 


\section{DISTRIBUTION}

1. C. W. Alexander

2. J. E Bigelow

3. T. M. Bonine

4. H. L Boston

5. W. D. Brickeen

6-7. K F. Eckerman

8. J. T. Etheridge

9. J. B. Fuqua, Jr.

10. S. B. Garland

11. L L Kaiser

12. A. J. Kuhaida

13-15. D. M. Matteo

16-17. P. T. Owen

18. C. E. Pepper

19. J. H. Platfoot

20. P. S. Rohwer

21. P. A. Schrandt

22 W. T. Thompson

23. M. L Whitehead

24. C. O. Wiles

25. P. S. Wood

26. ORNL ER Document Management Center

27. Central ER Ducument Management Center

28. Laboratory Records Department

29. ORNL Patent Section

30. Central Research Library

31. Office of Assistant Manager for Energy Research and Development, DOE Oak Ridge Operations Office, P.O. Box 2001, Oak Ridge, TN 37831-8600

32-33. Office of Scientific and Technical Information, P.O. Box 62, Oak Ridge, TN 37831 